UNIVERSIDADE DE BRASÍLIA

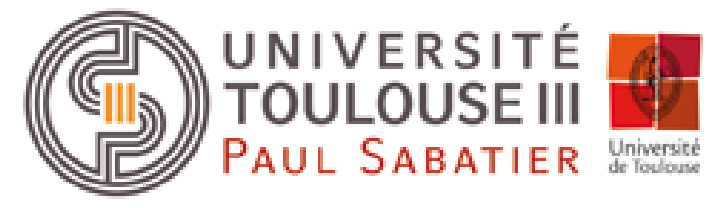

INSTITUTO DE GEOCIÊNCIAS

\title{
Investigations into isotope biogeochemistry of Zinc in coastal areas and mangroves
}

Investigações da biogeoquímica isotópica de Zn em áreas costeiras e de mangue

DANIEL FERREIRA ARAÚJO

Doctoral Thesis

Tese de Doutorado

$\mathbf{N}^{\mathbf{0}} \mathbf{1 3 3}$

Supervisor: Dr. Geraldo Resende Boaventura

Co-Supervisor: Dr. Jérôme Viers

Orientador: Dr. Geraldo Resende Boaventura

Co-orientador: Dr. Jérôme Viers

Brasília - DF

2016 


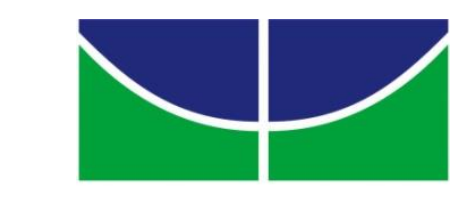

UNIVERSIDADE DE BRASÍLIA INSTITUTO DE GEOCIÊNCIAS

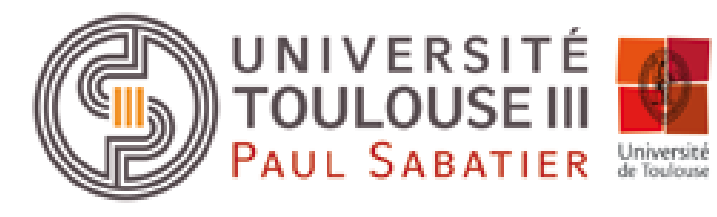

\section{Investigations into isotope biogeochemistry of Zinc in coastal areas and mangroves}

Investigações da biogeoquímica isotópica de Zn em áreas costeiras e de mangue

DANIEL FERREIRA ARAÚJO

Doctoral Thesis

Tese de Doutorado

$\mathbf{N}^{\mathbf{0} 133}$

Geraldo Resende Boaventura (orientador, UnB, Brasil)

Jérôme Viers (co-orientador, GET/UPS-III, França)

Jeremie Garnier (examinador interno, UnB, Brasil)

Lucieth Cruz Vieira (examinadora interna, UnB, Brasil)

Martin Roddaz (examinador externo, GET/UPS-III/IRD, França)

Cécile Quantin (examinadora externa, Paris-Sud, França)

Patrick Seyler (examinador externo, HSM/UM/IRD, França) 


\section{PREFACE}

This thesis was developed in a program of cooperation between the Universidade de Brasília-UnB (Brazil) and the Université Paul Sabatier III-UPS (France), and was supervised by the professors Dr. Geraldo Resende Boaventura (UnB) and Dr.Jérôme Viers (UPS). For meeting the agreement stablished by these two institutions, and due to the international relevance of this project, the English language was adopted. An expanded abstract in Portuguese is included at the end of this work.

\section{PREFÁCIO}

Esta tese foi desenvolvida pela cooperação entre a Universidade de Brasília (Brasil) e a Université Paul Sabatier III- UPS (França), e foi supervisionado pelos professores Dr. Geraldo Resende Boaventura (UnB) e Dr.Jérôme Viers (UPS). Para contemplar o acordo estabelecido pelas duas instituições, e tendo em vista a relevância internacional do projeto, a língua inglesa foi adotada. Um resumo expandido em português está incluído ao final deste trabalho.

\section{PRÉFACE}

Cette thèse a été réalisée par la coopération entre l'Université de Brasília-UnB (Brasíla) et l’Université Paul Sabatier III- UPS, et a été dirigée par les professeurs Dr. Geraldo Resende Boaventura (UnB) et Dr.Jérôme Viers. De façon à contempler l'accord établit par les deux institutions et la relevance internationale du projet, la langue anglaise a été adoptée. Un résumé étendu en portugais est inclus au final du manuscrit. 
À minha mãe, Dona "Ursa", por todo amor e café To my mother, Ms. "Bear", for all love and coffe 


\section{ACKNOWLEDGMENTS}

Finally, I've come to the very end of my challenging, but gratifying, journey. Through it, many were the people who helped me to overcome all obstacles and troubles put in my way; to them, here are my thanks:

First of all, to prof.Geraldo Boaventura for the nearly ten years of joint work, since my undergraduating time, as well as for the trusting and support invested in me along the development of a research line still unexplored in Brazil. For that matter, I couldn't fail to also thank prof. Sambasiva Patchinellem for the irrecusable invitation to discover the beautiful and fascinanting Sepetiba Bay, which, in fact, triggered this doctorate.

To prof. Jérôme Viers for accepting to take part in this project, opening the doors of Université Paul Sabatier and of the Géosciences Environnement Toulouse (GET) laboratory, where I was able to learn a lot and to enjoy good moments

My hearty thanks to prof. Wilson Machado, to whom only one paragraph is not enough to express my acknowledgment, such were his geochemical lessons and teachings, as well as our scientific discussions, his field support at UFF, encouragement and inspiration, not to mention all the casual and relaxation moments he made possible that also helped me to get over difficulties.

To prof. Dominik Weiss, for his substancial contribution to my scientific training and for showing me that through hard work, cooperation and goodwill one can achieve great deeds. I'm greateful that he betted and believed in this work as much as or even more than I did; I hope someday I hope someday I'm able to return it all.

To prof. Elton L. Dantas, for his trust and friendship, for allowing me to make the geocronology lab my second home, and, at last but not least, for conceding my scholarship, which turn into reality my dream to carry out the "sandwich" ph.D.

To prof. Marly Babinski, for her friendship and for the great opportunity to develop this joint work between Universidade de São Paulo and CPGeo Laboratory, that granted me excellent work conditions for the present project.

To prof. Jéremie Garnier, for the countless favors, the financial and laboratorial support, the scientific discussions, and the partnership and friendship, built up in our fun work travels to Paracatu.

To the most notable chemists in Brazil, Bárbara Alcântara, Izabel Ruiz and Jeane Chaves, for the support when facing the mass spectrometers, for sharing their knowledge and laboratorial experiences, for their patient at my countless requests for savillex and acids and, of course, for the good and pleasant time we spent together.

To geologist Erico Zacchi, for his friendship and helping hand during isotopic analysis at MC-ICP-MS of Brasília University.

To chemists Jonathan Prunier e Manuel Henry, for their support throughout the work in the clean room at GET.

To prof. Daniel Mulholland, for his friendship and scientific cooperation all over these years, and also for our previous and future publications; to Ronaldo Leite Filho, for his longtime friendship, as well as for the revisions, contributions and comments on several manuscripts and excerpts of this work.; and Roulin Khondoker for her substantial supporting on English text. 


\section{AGRADECIMENTOS}

Enfim, chego ao fim da minha desafiadora, porém gratificante jornada! Ao longo dela, muitas pessoas ajudaram a transpor as adversidades e percalços que a mim se apresentaram; para elas, aqui vão meus agradecimentos:

Primeiramente, ao prof. Geraldo Boaventura pelos quase dez anos de trabalho conjunto, desde meus tempos de graduação, pela confiança e em mim depositada e pelo apoio, no desenvolvimento de uma linha de pesquisa ainda inédita no Brasil. Nesse sentido, não posso deixar de agradecer também ao irrecusável convite do Prof. Sambasiva Patchinellem para explorar a fascinante e bela baía de Sepetiba, o qual efetivamente originou este doutorado.

Ao prof. Jérôme Viers por aceitar participar deste projeto, e abrir as portas da Université Paul Sabatier e do laboratório de Géosciences Environnement Toulouse (GET), onde muito aprendi e bons momentos desfrutei.

Ao prof. Wilson Machado, à quem um paragráfo não é suficente para expressar todo o meu agradecimento aos inúmeros ensinamentos geoquímicos, às discussões científicas, ao suporte de campo na UFF, ao incentivo, e à inspiração, além dos momentos de descontração, que muito ajudaram a transpor as dificuldades.

Ao prof. Dominik Weiss, por contribuir de forma substancial à minha formação científica, bem como por me mostrar que com trabalho duro, cooperação e boa vontade se conseguem grandes resultados. Muito agradeço por ter apostado e acreditado neste trabalho tanto quanto ou até mais do que eu. Espero um dia poder retribuir tudo isso.

Ao prof. Elton L. Dantas, pela amizade e confiança, por deixar que o Laboratório de Geocronologia se tornasse minha segunda casa e por me conceder a bolsa de estudos que viabilizou meu sonho de realizar o doutorado cotutela.

À profa. Marly Babinski, pela amizade e pela grande oportunidade de desenvolver este trabalho em cojunto entre a Universidade de São Paulo e o Laboratório CPGeo, os quais proporcionaram excelentes condiçoes de trabalho para este projeto.

Ao prof. Jéremie Garnier, pelos inúmeros favores à mim prestados, pelo suporte financeiro e laboratorial, pelas discussões científicas e pela grande parceria e amizade, consolidada nas divertidas viagens à Paracatu.

Às químicas mais notáveis do Brasil, Bárbara Alcantâra, Izabel Ruiz e Jeane Chaves, pelo suporte frente aos espectrômetros de massa, por compartilharem seus conhecimentos e experiências laboratoriais, pela paciência nos meus inúmeros pedidos por savillex e ácidos e, claro, pelos bons momentos de descontração e de agradável convivência.

Ao geológo Erico Zacchi, pela amizade e pela ajuda durante as análises isotópicas no MC-ICP-MS.

Aos químicos Jonathan Prunier e Manuel Henry, pelo suporte durante os trabalhos na sala limpa do GET.

Ao prof. Daniel Mulholland, pela amizade e pela cooperação científica de tantos anos, e também pelas antigas e futuras publicações.

A Ronaldo Leite Filho, pela amizade de anos, e pelas revisões, contribuições e comentários nos vários manuscritos e trechos deste trabalho.

E ainda a Roulin Khondoker, pela seu substancial suporte na correção do manuscrito inglês. 


\begin{abstract}
Coastal areas worldwide are under strong pressure from anthropogenic contamination, as most of the global population and of economic activities are concentrated along the coasts and estuaries. The threaten of contaminant releasing into these ecosystems makes imperative the development of tools capable of detecting biogeochemical changes in order to help prevention, monitoring and prediction of risks in environmental studies. In this way, this thesis investigates the isotope biogeochemistry of Zinc (Zn) in order to develop a tool capable of tracing natural and anthropogenic sources, identifying biogeochemical processes and enabling the biomonitoring of metal contamination in coastal areas and mangroves. To this end, $\mathrm{Zn}$ isotopes compositions were determined in several natural samples collected from Sepetiba bay (southeastern Brazil), an estuarinelagoon impacted by an industrialized coastal area near Rio de Janeiro. This bay constitutes an ideal natural laboratory for evaluating the $\mathrm{Zn}$ isotopic system to environmental issues, since it hosts important ecosystems of commercial and ecological interest - estuaries, mangroves and tidal flats - threaten by the metal contamination resultant of old electroplating activity and other anthropogenic diffuse sources. The collected samples include sediment cores, surface mangrove sediments, suspended particulate matter (SPM), leaves of mangrove's trees, tissues of bivalve mollusks (oysters and mussels) and rocks. Ores from Vazante deposit, Brazil were collected to represent the raw material used in the old electroplating industry. Firstly, an initial laboratory work established a method for accurate and precise determinations of $\mathrm{Zn}$ isotope compositions in natural samples by multi-collector inductively coupled plasmamass spectrometry (MC-ICP-MS). Spatial and temporal analysis of $\mathrm{Zn}$ isotope compositions of sediment and rock samples fits well in a model of mixing between three main end-members: i) continental materials brought via rivers; ii) marine sources; and iii) a major anthropogenic source associated to the old electroplating wastes released into the bay. Sediment cores collected in the mud flat showed high correlation between $\mathrm{Zn}$ isotope compositions and $\mathrm{Zn}$ enrichment factors, suggesting (i) good preservation of isotopic records of natural and anthropogenic sources and (ii) no significant isotopic fractionation during sediment transport or as a result of diagenetic reactions post-deposition in the estuarine system. The sediment core sampled from a mangrove located in the zone impacted by the old electroplating activity presented
\end{abstract}


levels of $\mathrm{Zn}$ up to $4 \%$ (dry weight) and preserved the isotopic signatures of electroplating wastes. However, there is evidence that biogeochemical processes triggered by hydrodynamics, bioturbation or rhizosphere processes slightly changed the isotopic signatures in some layers. Calculations based in this mixing model quantified contributions of the major anthropogenic source of $\mathrm{Zn}$, ranging from negligible values in the pre-industrial period to nearly $80 \%$ during periods of electroplating activities between the 60's and 90's. The Zn isotope systematics of mollusc bivalves were not associated to mixing process of sources. Instead, these bioisotopic signature seems related to different routes of bioaccumulation, i.e. uptake via dissolved or particulate phase. It is hypothesized that in the zone heavily impacted zone by old electroplating wastes, the bivalves incorporate the high levels of $\mathrm{Zn}$ in the dissolved phase though the bivalve gills, while outside this zone, these organisms incorporate the labile $\mathrm{Zn}$ bound to particulate matter during the gut digestion. Zinc isotopic signatures of leaves did not also allowed identification of sources due to the significant isotopic fractionation during $\mathrm{Zn}$ uptake by the roots. Leaves of sites highly contaminated presented different $\mathrm{Zn}$ isotopic patterns of those of low or no contaminated sites. These patterns may be associated to activation of tolerance mechanisms of mangrove's trees where $\mathrm{Zn}$ reach toxic levels. To conclude, $\mathrm{Zn}$ isotopes compositions of abiotic samples such as sediments are effective to detect biogeochemical changes triggered by anthropogenic activities and, therefore, can be useful to support prevention, monitoring and prediction of risks in coastal sites impacted by metal contamination. Biological samples of mollusc bivalves and leaves of mangrove's trees are not suitable to sources tracing, but the distinct isotopic patterns of $\mathrm{Zn}$ found for those samples from sites highly contaminated are promising as biomarkers of metabolic pathways and physiological effects associated to metal contamination. Future investigations are required to constrain the relationships among $\mathrm{Zn}$ speciation, uptake mechanisms and the $\mathrm{Zn}$ bioisotopic of leaves and bivalve tissues. 


\section{RESUMO}

Zonas costeiras do mundo afora estão sob forte pressão da contaminação antrópica, uma vez que a população global e as atividades econômicas concentram-se ao longo das costas e dos estuários. A ameaça de contaminantes nestes ecossistemas torna imperativo o desenvolvimento de ferramentas capazes de detectar mudanças biogeoquímicas no intuito de auxiliar a prevenção, o monitoramento e a predição de riscos em estudos ambientais. Assim, esta tese investiga a geoquímica isotópica do Zinco ( $\mathrm{Zn}$ ) de forma a desenvolver uma ferramenta capaz de traçar fontes naturais e antrópicas, identificar processos biogeoquímicos e possibilitar o biomonitoramento de contaminação metálica em áreas costeiras e mangues. Para este fim, composições isotópicas de $\mathrm{Zn}$ foram determinadas em várias amostras naturais coletadas na baía de Sepetiba (sudeste do Brasil), um estuário lagunar impactado por uma costa industrializada próximo à cidade do Rio de Janeiro. Esta baía constitui um laboratório natural ideal para avaliação do sistema isotópico de $\mathrm{Zn}$ para questões ambientais, pois apresenta importantes ecossistemas de interesse comercial e ecológico - estuários, mangues e planícies de maré - ameaçados pela contaminação de uma antiga atividade galvânica e outras fontes difusas. As amostras coletadas incluem testemunhos de sedimento, sedimentos superficiais de mangue, folhas de árvores de mangue, tecido mole de moluscos bivalves (ostras e mexilhões) e rochas. Minérios do depósito de Vazante (Minas Gerais, Brasil), também foram coletadas para representar a matéria-prima utilizada na antiga atividade galvânica. Primeiramente, um trabalho laboratorial inicial estabeleceu um método acurado e preciso para determinações isotópicas de $\mathrm{Zn}$ em amostras naturais por espectrometria de massa com plasma indutivamente acoplado e multi-coletor (MC-ICPMS). Análises espaciais e temporais dos resultados das composições isotópicas de Zn de amostras de sedimento e rocha se ajustam à um modelo de mistura entre três membros finais: i) materiais continentais carreados pelos rios; ii) fontes marinhas; e iii) uma fonte antropogênica principal associada a antigos rejeitos de galvanoplastia lançados na baía. Testemunhos de sedimento coletados na planície lamosa mostraram altas correlações entre as composições isotópicas de $\mathrm{Zn}$ e fator de enriquecimento de $\mathrm{Zn}$, sugerindo (i) uma boa preservação dos registros isotópicos de fontes naturais e antrópicas, e (ii) ausência de fracionamento isotópicos significativos durante o transporte de sedimentos ou em reações diagenéticas pós-deposição no sistema estuarino. O testemunho de 
sedimento coletado em um mangue localizado na zona impactada pelos antiga atividade galvânica apresentou níveis de Zn acima de 4\% (peso seco) e preservou as assinaturas isotópicas dos rejeitos da galvanoplastia. Entretanto, há evidências de que processos biogeoquímicos promovidos por processos hidrodinâmicos, biotubarção e rizosfera podem alterar sutilmente as assinaturas isotópicas em algumas camadas do perfil. Cálculos baseados neste modelo de mistura quantificaram contribuições da principal fonte antropogênica variando de valores desprezíveis em períodos pré-industriais até $80 \%$ durante períodos da atividade eletrogalvânica entre as décadas de 60 e 90 . A sistemática dos isótopos de $\mathrm{Zn}$ de bivalves não foi associada a processos de mistura de fonte. Em vez disso, suas assinaturas bioisotópicas parecem estar relacionadas às diferentes rotas de bioacumulação, i.e, via incorporação da fase dissolvida ou particulada. A hipótese é que na zonas severamente impactadas pelos antigos rejeitos da galvanoplastia, os bivalves incorporam altas concentrações de $\mathrm{Zn}$ na fase dissolvida através das brâquias, enquanto fora desta zona, estes organismos incorporam o Zn lábil ligado ao material partículado durante a digestão. Assinaturas isotópicas de $\mathrm{Zn}$ de folhas também não permitiram a identificação de fontes por causa do significativo fracionamento isotópico durante a incorporação do $\mathrm{Zn}$ pelas raízes. Folhas de ambientes contaminados apresentaram padrões isotópicos de $\mathrm{Zn}$ diferentes dos padrões encontrados em folhas de áreas pouco ou não contaminadas. Estes padrões podem estar associados à ativação de mecanismos de tolerância pelas árvores do mangue onde as concentrações de Zn atingem concentrações tóxicas. Em conclusão, as composições isotópicas de $\mathrm{Zn}$ de amostras abióticas como sedimentos são efetivas para detectar mudanças biogeoquímicas desencadeadas por atividades antrópicas e, portanto, podem ser úteis para dar suporte à prevenção, ao monitoramento e à predição de riscos em áreas impactadas pela contaminação metálica. Amostras biológicas de moluscos bivalves e folhas de árvores de mangue não são adequadas para traçar fontes, porém, os distintos padrões isotópicos de $\mathrm{Zn}$ encontrados para amostras de ambientes altamente contaminados são promissores para aplicar isótopos de Zn como biomarcadores de reações metabólicas e efeitos fisiológicos associados à contaminação metálica. Futuras investigações são necessárias para compreender as relações entre a especiação de Zn, mecanismos de incorporação e as assinaturas bioisotópicas de tecidos de bivalves e folhas. 


\section{RÉSUMÉ}

Les zones côtières du monde entier sont sous fort pression de contamination anthropique comme conséquence de la concentration de la plupart de la population mondiale et des activités économiques le long des côtes et des estuaires. La menace de contaminant sur les écosystèmes rend primordial le développement d'outils capable de détecter les modifications biogéochimiques en vue d'aider dans la prévention, la gestion, et la prédiction de risques dans les études environnementales. Dans ce but, cette thèse étudie la biogéochimie des isotopes du Zinc (Zn) en vue de développer un outil capable de tracer les sources naturelles et anthropiques, d'identifier les processus biogéochimiques et de permettre à la biosurveillance de la contamination par les métaux dans les zones côtières et les mangroves. A cette fin, les compositions isotopiques du $\mathrm{Zn}$ ont été déterminées à plusieurs échantillons naturels prélevés dans la baie de Sepetiba (au sud-est du Brésil), un estuaire lagunaire affecté par une côte industrialisée située près de Rio de Janeiro. Cette baie constitue un laboratoire naturel idéal pour valider le système isotopique du Zn. En effet, cette zone héberge des écosystèmes d'intérêt commercial et écologique -estuaire, mangrove, estran- menacés par la contamination d'une ancienne activité de galvanoplastie, et d'autres sources diffuses. Les échantillons collectés comprennent des carottes de sédiments, des sédiments de la superficie des mangroves, des matériaux particulaires en suspension (SPM), des feuilles provenant d'arbres de mangrove, des tissus de mollusques bivalves (huîtres et moules) et des roches. Minéraux de dépôt de Vazante (Brésil) ont été collecté pour representé matière première utilisée par l'industrie de la galvanoplastie. Tout d'abord, un travail initial de laboratoire a établi une méthode exacte et précise pour les déterminations isotopiques Zn en échantillons naturelles par spectrométrie de masse avec plasma couplé par induction et multicollecteur (MC-ICP-MS). Des analyses spatiales et temporelles des compositions isotopiques du $\mathrm{Zn}$ des échantillons de sédiments et de roches s'ajustent bien à un modèle de mélange entre trois principales extrémités: i) les matériaux continentaux charriés par les rivières; ii) les sources marines; et iii) une source anthropique majeure associée aux anciens déchets de galvanoplastie jetés dans la baie. Les carottes de sédiment collectées dans la vasière ont montré une haute corrélation entre la composition isotopique du $\mathrm{Zn}$ et le facteur d'enrichissement du Zn. Ceci suggère: i) une bonne préservation du registre isotopique des sources naturelle et anthropique, ii) l'absence de fractionnement isotopique significatif durant le transport de sédiments ou durant les réactions diagénétiques pos-dépositions dans le système 
estuarien. La carotte de sédiments collectée dans la mangrove, située dans la zone impactée par l'ancienne activité galvanoplastique a présenté des concentrations de Zn au-dessus de $4 \%$ (pèse sec) et a préservé les signatures isotopiques des déchets de la galvanoplastie. Cependant, il est évident que les processus biogéochimiques déclenchés par les processus hydrodynamiques, par la bioturbation, et par la rhizosphère peuvent altérer les signatures isotopiques de certaines couches de sédiment. Les calculs basés sur ce modèle de mélange quantifient les contributions de la principale source anthropique variant de valeurs négligeables en périodes préindustrielles jusqu'aux $80 \%$ pendant les périodes d'activités de galvanoplastie entre les années 60 and 90. La systémique des isotopes du $\mathrm{Zn}$ des mollusques bivalves n'est pas associée au processus de mélange des sources. Au lieu de cela, ces signatures bioisotopiques semblent liées à différentes routes de bioaccumulations, i.e. par l'incorporation de phase dissoute ou de particules. L'hypothèse est que, dans les zones sévèrement impactées par les anciens rejets de galvanoplastie, les bivalves incorporent les hautes concentrations du $\mathrm{Zn}$ sous forme dissoute via les branchies. Cependant, hors de cette zone, ces organismes incorporent via la digestion le $\mathrm{Zn}$ labile. Les signatures isotopiques du $\mathrm{Zn}$ des feuilles également n'ont pas permis l'identification des sources en raison du fractionnement isotopique significatif au cours de l'incorporation du $\mathrm{Zn}$ par les racines. Les feuilles des sites hautement contaminé ont montré des standards isotopiques du $\mathrm{Zn}$ diffèrent des feuilles des sites peu ou non contaminé. Ces standards peuvent être associés à l'activation de mécanismes de tolérance par les arbres de la mangrove où le $\mathrm{Zn}$ atteint des niveaux toxiques. En conclusion, les compositions isotopiques du $\mathrm{Zn}$ des échantillons abiotiques, comme les sédiments, permettent de détecter les changements biogéochimiques déclenchés par des activités anthropiques. Ainsi, elles sont utiles pour donner des supports á la prévention, á la gestion, et á la prédiction de risques dans les zones impactées par la contamination métallique. Échantillons biologiques de mollusques bivalves et de feuilles provenant d'arbres de mangroves ne sont pas appropriés pour tracer les origines du Zn. Cependant, les distinctes compositions isotopiques du $\mathrm{Zn}$ des échantillons collecté aux sites hautement contaminé sont prometteurs pour l'application de ces isotopes comme marqueurs biologiques de réactions métaboliques et de réponse physiologiques. Toutefois, il faut plus de recherches afin de comprendre la relation entre la speciation du $\mathrm{Zn}$, mécanismes de d'incorporation et les signatures bioisotopiques de cet élément dans les tissus de bivalves et feuilles. 


\section{Summary}

Chapter 1:Introduction....................................................................................1

1.1 The relevance of isotope biogeochemistry to environmental studies................................................................

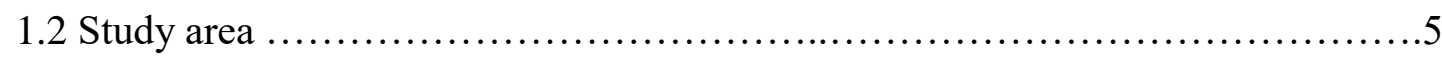

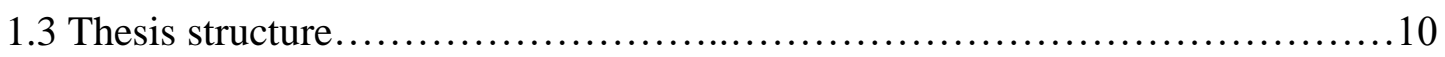

References..........................................................11

Chapter 2: The trace metal biogeochemistry in coastal zones and mangroves...................................................................................................................15

2.1 Trace metal in the estuarine system: sources, transport and fates...............16

2.2 Biogeochemistry processes in the intertidal zones:

tidal flats and mangroves............................................... 22

2.3 Bivalve molluscs: ecological importance and applicability as

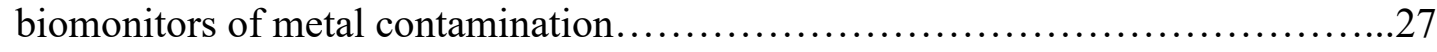

2.4 Bivalve mollusc morphology and feeding behavior........................30

2.5 Metal bioaccumulation mechanisms and their implications for

Environmental risk assessing............................................ 31

References.......................................................... 36

Chapter 3: Zinc stable isotope biogeochemistry: a review.......................41

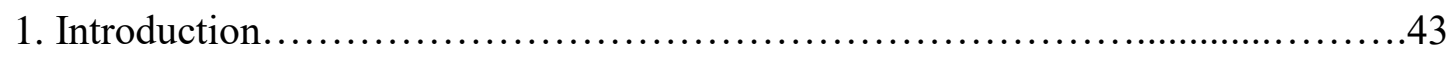

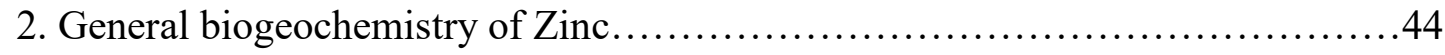

3. Sample preparation for isotope analysis................................46

3.1 Solid and water samples...........................................46

3.2 Analyte separation: eliminating matrix interferences.......................48

4. The MC-ICP-MS instrumentation........................................49

5. Data reporting and analytical quality control............................52

6. Metal isotope fractionation mechanisms ..................................55 
7. Zinc isotopic fractionation in natural and anthropogenic processes................58

7.1 High temperature igneous processes and extraterrestrial materials..............58

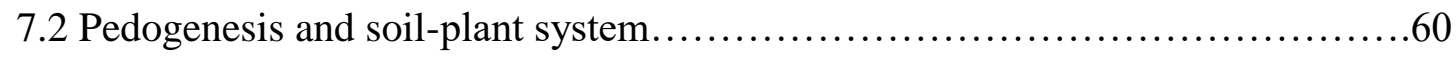

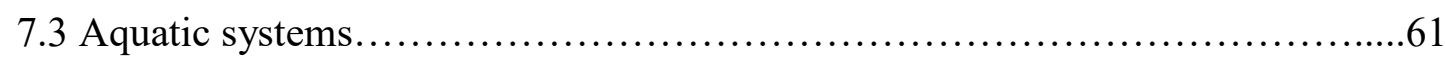

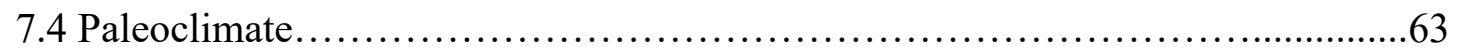

7.5 Ore deposits, coal and industrial and metallurgical processes..................64

7.6 Dietary, trophic chains and human body..............................67

8. Conclusions ....................................................... 70

References........................................................... 71

Chapter 4: Ion exchange chromatography and mass bias correction for accurate and precise $\mathrm{Zn}$ isotope ratio measurements in environmental reference materials by MC-ICP-MS..............................................................77

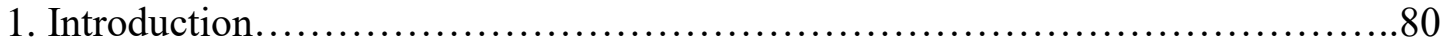

2. Experimental...................................................... 81

2.1 Reagents, standards and reference materials............................... 81

2.2 Isotopic reference materials and data presentation.........................82

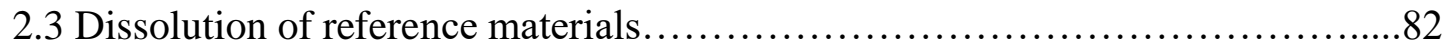

2.4 Determination of elemental concentration................................. 83

2.5 Zinc chromatographic separation: column specifications and development of the elution protocol.................................. 83

2.6 Assessment of the ion exchange chromatography procedure..................84

2.7 Instrumental mass bias corrections....................................... 86

2.8 Effect of variable analyte-dopant $(\mathrm{Zn} / \mathrm{Cu})$ ratios on $\mathrm{MC}-\mathrm{ICP}-\mathrm{MS} \ldots \ldots \ldots \ldots \ldots . . . . . .88$

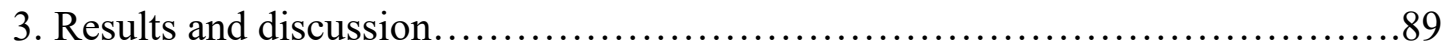

3.1 Assessing the ion exchange chromatographic procedure: recovery, reproducibility, matrix separation and blanks

3.2 Determining the optimum analyte-dopant ratio $(\mathrm{Zn} / \mathrm{Cu})$

of isotopic measurements. 
3.3 Assessing spectral and non-spectral interferences effects on $\mathrm{Zn}$ isotopic rations.

3.4 $\mathrm{Zn}$ isotopic compositions of environmental RMs.............................94

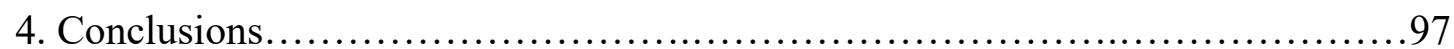

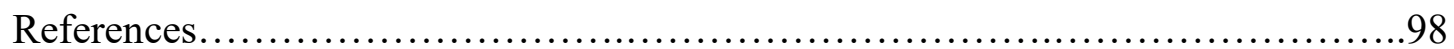

Chapter 5: Zinc isotopes as tracers of waste from electroplating

industries in coastal environments.........................................101

1. Introduction............................................................ 103

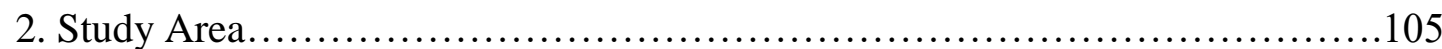

2.1 General characteristics......................................................

2.2 History of environmental impacts.................................... 106

3. Materials and Methods.................................................. 107

3.1 Sampling and sample preparation..................................... 107

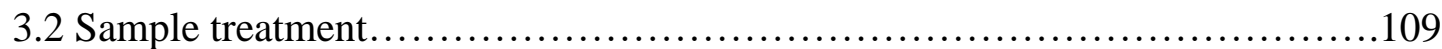

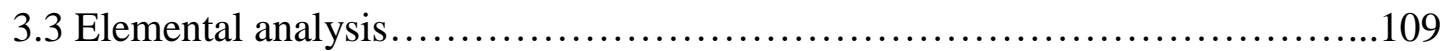

3.4 Enrichment factor, bio-concentration factor and multivariate statistic...........110

$3.5 \mathrm{Zinc}$ isotope analysis............................................. 110

3.6 Zinc isotopic data presentation, reproducibility and accuracy................111

4. Results..................................................................... 112

4.1 Zinc isotopic compositions and enrichment factors of sediment cores...........112

4.2 $\mathrm{Zn}$ isotopic compositions of rocks and willemite ores.......................114

4.3 $\mathrm{Zn}$ isotopic compositions of surface sediments and mangrove leaves..........114

4.4 $\mathrm{Zn}$ isotopic compositions of suspended particulate matter (SPM) $\ldots \ldots \ldots \ldots \ldots \ldots 115$

4.5 Major and trace elements profiles of sediment cores.........................116

4.6 Multivariate statistics of sediment cores in Sepetiba bay.......................116

4.7 SEM/EDS analysis of sediments.....................................117 
5. Discussion

5.1 Identifying sediment sources and processes with multivariate statistics

5.2 Deciphering Zn isotopic signatures in the coastal system: mixing sources or/and biogeochemical processes during sediment transport and diagenesis?

5.3 Tracing $\mathrm{Zn}$ contamination in mangrove sediments using stable isotope composition.

5.4 Effects of anthropogenic contamination on $\mathrm{Zn}$ isotope compositions of mangrove tree leaves.

5.5 Quantifying the anthropogenic $\mathrm{Zn}$ inputs in the past and present days

5.5.1 The $\mathrm{Zn}$ isotope signatures of electroplating wastes....

5.5.2 Zinc isotope signatures of natural and terrestrial sources

5.5.3 Quantifying past and present anthropogenic inputs

6. Conclusions 128

References.

Chapter 6: Zinc isotopes compositions in bivalve molluses tissues from a Brazilian estuary: implications for biomonitoring of metal contamination.

1. Introduction. 152

2. Study area. 153

3. Materials and Methods. 154

3.1 Sampling and sample preparation.... 154

3.2 $\mathrm{Zn}$ concentrations and isotope ratio analysis.... 156

3.3 Statistical analysis 158

4. Results 158

4.1 $\mathrm{Zn}$ particulate isotopic composition and $\mathrm{Zn}$ dissolved concentrations. 158

4.2 $\mathrm{Zn}$ isotopic compositions of oysters and mussels. 159

5. Discussion.

5.1 The $\mathrm{Zn}$ isotopic signatures of sediment plume in the fluvial-estuarine system...159 
6. Conclusions ........................................................... 163

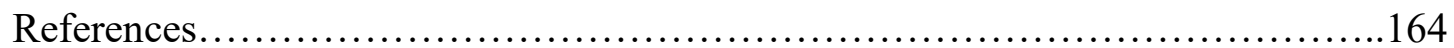

Chapter 7: Main findings and Conclusions..................................173

RESUMO ESTENDIDO EM PORTUGUÊS....................................176

Capítulo 1- Contexto, objetivos e área de estudo.................................................176

Capítulo 2- Biogeoquímica de metais-traços em ambientes costeiros e de mangue.. 180

Capítulo 3- Biogeoquímica dos isótopos estáveis de $\mathrm{Zn}$ : uma revisão........................183

Capítulo 4- Cromatografia de troca iônica e correções de viés de massa para medição acurada e precisa das razões isotópicas de $\mathrm{Zn}$ em amostras ambientais de referência por MC-ICP-MS

Capítulo 5- Isótopos de $\mathrm{Zn}$ como traçador de rejeitos metalúrgicos em ambientes costeiros. 189

Capítulo 6- Composições isotópicas de Zn de moluscos bivalves de um estuário brasileiro: implicações para biomonitoramento de contaminação por metais.

Capítulo 7- Conclusões 192 


\section{List of figures}

\section{Chapter 1:Introduction}

Fig.1. Localization of Sepetiba bay....

\section{Chapter 2: The trace metal biogeochemistry in coastal zones and mangroves}

Fig.2. Pathways for contaminant toxicity and bioaccumulation on mangrove ecosystems. Source: Lewis et al., 2011.

Fig.3. Schematic representation of the different fluxes of trace metals between aquatic ecosystems (A), with emphasis on the geochemical processes regulating metal cycling in the water column (B) and in sediments (C). Trace metals may reach aquatic systems via: (1) waste water treatment; (2) tributaries, surface runoff from (3) roads and (4) agricultural lands and soils, (5) exchange with groundwater, (6) atmospheric deposition, (7) release from sediments; they may be eliminated through: (8) discharge in effluents, (9) evaporation, (10) uptake by surrounding vegetation and organisms, (11) infiltration into subterranean waters, (12) reaction in the upper sediment layers, (13) adsorption by suspended matter, and (14) sedimentation. Source: Tercier-Waeber and Taillefert, 2008.

Fig.4. Schematic view of the electrical double layer at a mineral/aqueous solution interface showing possible inner-sphere $\left(\mathrm{Pb}^{2+}\right)$ and outer-sphere $\left(\mathrm{Cl}, \mathrm{Na}^{+}, \mathrm{SO}_{4}{ }^{2-}\right)$ complexes and the drop off of the electrical potential away from the interface. Source: Hayes, 1987.

Fig.5. Schematic illustration of different modes of $\mathrm{Sr}\left(\mathrm{H}_{2} \mathrm{O}\right)_{8}{ }^{2+}$ sorption onto $\mathrm{Mn}$ oxidehydroxides surfaces. Source: Grolimund et al., 2000

Fig.6. Bacterial decomposition of organic matter in marine/estuarine sediment through a sequence of terminal electron acceptors (e.g., $\mathrm{O}_{2}, \mathrm{NO}_{3}{ }^{-}, \mathrm{MnO}_{2}, \mathrm{FeOOH}, \mathrm{SO}_{4}{ }^{2-}$ and $\mathrm{CO}_{2}$ ) and changing redox. Source: Li et al., 2015, modified from Canfield and Thamdrup, 2009.

Fig.7. Interactions between Fe mineral phases and inorganic and organic contaminants and the transformations and variations that occur due to sediment biogeochemistry. (1) Ageing transformations from poorly crystalline phases (e.g. ferrihydrite, schwertmannite) to more crystalline phases (e.g. goethite, hematite) typically lead to an expulsion of adsorbed contaminants due to decreases in mineral surface area. However, divalent cations associated with the more crystalline phases typically become more recalcitrant. (2) Reductive dissolution of Fe oxide minerals leads to the release of adsorbed and co-precipitated contaminants, with a concomitant release of reduced $\mathrm{Fe}(\mathrm{II})$ into solution. (3) Disturbances to the sediment structure during diagenesis (e.g. bioturbation, dredging and sediment re-suspension) can lead to speciation changes (due to infiltrating $\mathrm{O}_{2}$ ) and can also lead to release of contaminants into the water column, thus posing a threat to aquatic organisms. (4) The released flux of Fe(II) can act as an 
electron donor during coupled redox transformation of contaminant phases. This is the premise on which the $\mathrm{Fe}(0)$ and $\mathrm{Fe}(\mathrm{II})$ amendment strategies are based. (5) The reduced $\mathrm{Fe}$ (II) flux can also reprecipitate at the redox boundary to form poorly crystalline phases (including mixed metal species such as FeAsO4-H2O) which can incorporate various trace metal contaminants. (6) Under highly anaerobic conditions, sulphur speciation has the strongest control on contaminant chemistry. Pyrite readily precipitates and can incorporate trace metals such as Co and Ni. Source: Heyden and Roychoudhury, 2015

Fig.8. A laterally compressed body is the most distinctive feature of bivalves, illustrated here by a clam. The gills, which hang on both sides of the body (a, c), sort out food particles and transport them to the mouth with the help of cilia and mucus. The palps then push the food into the mouth. Food is then digested in the stomach with the help of the crystalline style (b). The path of the particles from the incurrent siphon to the mouth is indicated by arrows (d). Source: (Castro and Huber, 2010). 31

Fig.9. Conceptual model of the main processes and sources for uptake of trace metals at a biological membrane. (M-C metal complex, M-Imetal ion, M-LB labile particlebound metal, M-T metal at target site, M-L metal bound to a biological ligand). Source: Ahlf et al., 2009.

Fig.10. Conceptual view of the biokinetic model and the equations used to understand the concentrations of trace metals accumulated by aquatic invertebrates. If : influx rate of metal from food ( $\mu$ g metal $\mathrm{g}^{-1}$ animal dry $w \mathrm{~d} \mathrm{~d}^{-1}$ ); Cf : metal concentration in the food ( $\mu \mathrm{g}$ metal $\mathrm{g}^{-1}$ food dry $\left.\mathrm{wt}\right)$; IR: ingestion rate ( $\mathrm{g}$ food dry wt $\mathrm{g}^{-1}$ clam dry $\mathrm{wt}$ ); AE: assimilation efficiency of ingested metal; Iw: the influx rate from water ( $\mu \mathrm{g}$ metal $\mathrm{g}^{-1}$ animal dry wt $\left.\mathrm{d}^{-1}\right)$; ku: uptake rate constant from dissolved phase $\left(\mathrm{l} \mathrm{g}^{-1} \mathrm{~d}^{-1}\right)$; Cw: metal concentration in dissolved phase $\left(\mu \mathrm{gl}^{-1}\right)$; b: power of the relationship, typically $=1 \pm 0.1$, unless metal uptake is biologically regulated; ke : the rate constant of loss (from the slowest compartment; $\mathrm{d}^{-1}$ ); C2and C3,ke and ke:metal concentrations in compartments $\mathrm{Cn}$ in the clam with loss rates. Source: Griscom and Fisher, 2004.

\section{Chapter 3: Zinc stable isotope biogeochemistry: a review}

Graphical abstract.

Fig.1. a) A multicollector-inductively coupled plasma mass spectrometry (MC-ICPMS) from the laboratory of Estudos Geodinâmicos e Ambientais (University of Brasília); b) A chromatographic column packed with ionic exchange resin AG MP-1

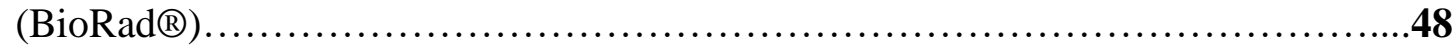

Fig.2. Scheme of a reverse geometry double-focusing magnetic-sector mass spectrometer. Source: Moldovan et al., 2004.

Fig.3. Zinc isotope fractionation during chemical reactions is fundamentally a quantum chemical phenomenon that arises from differences in the basal energies between 
chemical bonds of the isotopes. The bond between atoms in a molecule can be modeled as a spring. The vibration frequency $(f)$ of a ${ }^{64} \mathrm{Zn}-{ }^{16} \mathrm{O}$ bond is higher than the vibration frequency of a ${ }^{66} \mathrm{Zn}-{ }^{16} \mathrm{O}$ bond, and therefore, is broken faster than the bond of the heavy isotope.

Fig.4. A hypothetic isotopic fractionation during a reaction where phase A reacts to phase B, under (1) equilibrium conditions in a closed system (Eq-A and Eq-B, dotted lines)and (2) unidirectional conditions (Ral-A and RalB, solid lines). The initial isotope ratio of the system is $0.2 \%$ (only phase $\mathrm{A}$ is present), and the fractionation factor is $0.2 \%$; thus $\alpha_{\mathrm{B}-\mathrm{A}}=0.998$

Fig.5. Lithostratigraphy and isotope chemostratigraphy of the investigated Nuccaleena cap dolostone section.

Fig.6. Conceptual model for predicting $\mathrm{Zn}$ isotopic fractionation during coal combustion, after pass by the boiler and electrostatic precipator (ESP) steps. Source: Gonzalez and Weiss, 2015.

Fig.7. Zinc isotope compositions (expressed relative to JMC standard) of the main geochemical compartments, anthropogenic and environmental polluted samples and biological samples.a-Sonket et al., 2008; b- Chen et al., 2013; c-Vance et al., 2016 ; Viers et al., 2015; d- Maréchal et al., 2000; Bentahila et al., 2008; e-Chen et al., 2009; f-Dong et al., 2013;g-Zhao et al., 2014; h-Maréchal et al., 2000; i-Little et al., 2014 ; Petit et al., 2015;j-Kuzmann et al., 2012; 1-Sivry et al., 2008; m-Mattielli et al., 2009; n-Gioia et al., 2008 ; o-Weiss et al., 2007; p-Juillot et al., 2011; q-Aucour et al., 2011; r- Shiel et al., 2012; Shiel et al., 2013 ; Petit et al., 2015; s- Costa-rodriguez et al., 2014. .69

Chapter 4: Ion exchange chromatography and mass bias correction for accurate and precise $\mathrm{Zn}$ isotope ratio measurements in environmental reference materials by MC-ICP-MS

Graphical abstract.

Fig.1. The effect of variable $\mathrm{Cu} / \mathrm{Zn}$ ratios performed on the Neptune USP using the mixed reference isotopic solution ( $\mathrm{Zn} \mathrm{UnB}+\mathrm{Cu}$ NIST SRM 976). The $\mathrm{Cu} / \mathrm{Zn}$ ration of 1 showed the closest slope to the theoretical value $(\approx 0.96)$ and the best coefficient of determination $\left(\mathrm{R}^{2}=0.99\right)$

Fig.2. Plot of $\ln \mathrm{R}\left({ }^{66} \mathrm{Zn} /{ }^{64} \mathrm{Zn}\right)$ versus $\ln \mathrm{R}\left({ }^{65} \mathrm{Cu} /{ }^{63} \mathrm{Cu}\right)$ for 121 measurements of the isotopic solution ( $\mathrm{Zn} \mathrm{UnB}+\mathrm{Ni}$ NIST 986) over several analytical sessions on consecutive days using the Neptunes of USP and UnB universities over a year. The slopes of the mass bias lines obtained in both instruments (1.17 at USP and 1.05 at $\mathrm{UnB})$ is close to the theoretical value $(\approx 0.96)$ indicating that $f C u \approx f Z n$. Moreover, both instruments maintained good correlations between the $\mathrm{Cu}$ and $\mathrm{Zn}$ isotopic ratios. In general, the Neptune-UnB showed large mass bias drift over time. 
Fig.3. Interference assessed for different elements of the $\mathrm{Zn}$ isotopic compositions. The $\delta$-values of doped mixed reference isotopic solution ( $\mathrm{Zn} \mathrm{UnB}+\mathrm{Cu}$ NIST SRM 976) were calculated against the undoped bracketed mixed reference solution using the sample standard bracketing (SSB) and external normalization (Ext) corrections......94

\section{Chapter 5: Zinc isotopes as tracers of waste from electroplating industries in coastal environments}

Fig.1. Map of the study area and location of sampling sites. The mangrove surface sediment samples (not shown) were collected in the mangrove of Saco do Engenho, the mangrove region surrounding the São Francisco Channel and the mangrove located in Enseada das Garças. In the zoom at left is shown the northeastern shore where are located the main river and channels that disembogues in the Sepetiba Bay and the sediments cores collected in the Saco do Engenhos'mangrove (T1), in the inner bay close the mouth of Saco do Engenho (T2) and in the estuary mouth of São Francisco Channel(T3)

Fig.2. Sediment core profiles of the $\delta^{66} \mathrm{Zn}_{\mathrm{JMC}}$ values, $\mathrm{Zn}$ enrichment factor (EF) and majorelements.

Fig.3. (A) The plot between $\delta^{66} \mathrm{Zn}_{\mathrm{JMC}}$ values against $\mathrm{Zn}$ concentrations of granite rocks, sediment samples (SPM, cores and from surface of mangroves) and willemite ores. The dashed squares and the grey rectangle (highlighting the Earth crust) indicate $\delta^{66} \mathrm{Zn}_{\mathrm{JMC}}$ values of naturals and anthropogenic materials reported in the literature for: a- the Earth Crust $(+0.28 \pm 0.05 \%, 2 \sigma$, Chen et al., 2013); b- Marine carbonates (from +0.04 to $+1.34 \%$, Kunzmann et al.2013; Pichat et al., 2003); c-Sewage and wastewater (from +0.08 to $+0.31 \%$; Chen et al., 2009); d- Metallurgic wastes (from +0.59 to +0.81 , excluding outliers, Jullliot et al., 2011; Sivry et al., 2008); e- ZnS ores (+0.16 $\pm 0.20 \%$, $2 \sigma$, Sonke et al., 2008); f- Zn refined materials (from +0.1 to +0.3 , John et al., 2007). (B) The plots between $\delta^{66} \mathrm{Zn}_{\text {JMC }}$ against concentration and enrichment factor (EF) of the core samples and the respective correlations $\left(\mathrm{R}^{2}\right)$. T1 core did not present a clear relation between $\delta^{66} \mathrm{Zn}$ values and $\mathrm{EF}$, but at the first $35 \mathrm{~cm}$ a moderate correlation of $\mathrm{R}^{2}=0.51$ was obtained (not shown).

Fig.4. (A) The plots of $\delta^{66} \mathrm{Zn}_{\mathrm{JMC}}$ values against $\mathrm{Zn}$ concentrations of leaves (L.racemosa) and surface sediment samples; (B) BSAF against $\mathrm{Zn}$ concentrations of

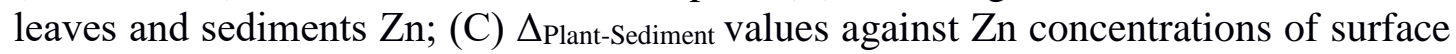
sediments and BSAF value....

Fig.5. The plots of the variables factor loads (A) and sample factor scores (B) obtained in PCA analysis.

Fig.6. Scanning electron microscope (SEM): (a) framboids and diatoms; (b) framboids in details; (c) association of many framboids; (d) framboids coated by clayminerals.142

Fig.7. Summary of the main findings obtained in this study on Sepetiba bay: the main sources identified with $\mathrm{Zn}$ isotopes: electroplating wastes as the major anthropogenic source, terrigenous and marine materials. Diffuse sources with a hypothetic $\delta^{66} \mathrm{Zn}_{\mathrm{JMC}}$ 
values $\approx 0.1 \%$ are suspected of influencing of the isotopic record of cores at southern region of the bay. In the mangrove profile collected in the old metallurgic zone, superficial layers are similar to SPM exported to the bay and the mud flat isotopic signatures. The deepest layers tends to heavier isotopic compositions possibly due the $\mathrm{Zn}$ isotopic fractionation related to combination of diagenetic processes, bioturbation, rhizosphere processes that taking place within sediments. Leaves isotopic signatures change from mangrove trees under high toxicity levels of $\mathrm{Zn}$ contamination to that under low contamination.

Fig.8. Quantification of anthropogenic $\mathrm{Zn}$ in the cores of inner bay. A mixing model was used to quantify the influence of electroplating wastes along the time. The representative $\delta^{66} \mathrm{Zn}$ values of end members were $+0.86 \pm 0.15 \%$ o $(2 \sigma)$ and $+0.28 \pm$ $0.12 \%(2 \sigma)$ to electroplating wastes and continental source (terrigenous materials brought by the rivers) respectively

144

\section{Chapter 6: Zinc isotopes compositions in bivalve molluses tissues from a Brazilian estuary: implications for biomonitoring of metal contamination}

Fig.1. Map of sampling in Sepetiba bay. At left, it is shown a zoom in the old metallurgic zone, where the electroplating activity operated from 60's to end of 90's. The dashed circle line highlight the Saco do Engenho mangrove, one site heavily impacted by the wastes lixiviated from the old wastes produced by the electroplating processes. Bivalve sampling stations: P1-Saco do Engenho; P2- Gato; P3-Martins; P4Itacurussá; P5- Jaguanum.

Fig.2. Zinc three-isotope plots for SPM, oyster and mussels samples follow the massdependent fractionation law of slope 1.93 .

Fig.3. The $\delta^{66} \mathrm{Zn}_{\mathrm{JMC}}$ of SPM samples against conductivity 171

Fig.4. The $\delta^{66} \mathrm{Zn}_{\mathrm{JMC}}$ and $\mathrm{Zn}$ concentrations of SPM, oysters and mussels samples of Sepetiba bay. The error bars $(2 \sigma)$ correspond to $0.07 \%$. Together are presented $\delta^{66} \mathrm{Zn}_{\text {JMC }}$ values of bivalves mollusks reported in previous studies in their respective errors $(2 \sigma)$ reported

Fig.5. Model of $\mathrm{Zn}$ isotope fractionation for bivalve mollusks of Sepetiba bay. The $\delta^{66} \mathrm{Zn}_{\mathrm{JMC}}$ values of can be explained by two different routes of $\mathrm{Zn}$ bioaccumulation: one via dissolved phase and other via particulate phase, with preferential incorporation of the labile $\mathrm{Zn}$ bound-particles. Light refers to enrichment of light isotopes in the dissolved phase promoted by sorption processes at interfaces of solid surfaces, as demonstrated and predicted in experimental and theoretical studies (Bryan et al., 2015; Szynkiewicz and Borrok, 2016). 


\section{List of tables}

Chapter 3: Zinc stable isotope biogeochemistry: a review

Table 1: Main Zinc isotope compositions of reference isotopic standards and reference materials

Chapter 4: Ion exchange chromatography and mass bias correction for accurate and precise $\mathrm{Zn}$ isotope ratio measurements in environmental reference materials by MC-ICP-MS

Table 1. Original Protocol of Maréchal et al. ${ }^{12}$ and the modified protocol used in this study

Table 2. Typical Neptune operating conditions of the USP and UnB laboratories...86

Table 3. Zinc recovery yields and reproducibility data obtained for replicates of reference materials.

Table 4. Accuracy and reproducibility for the isotopic reference solution ( $\mathrm{Zn} \mathrm{UnB}+$ $\mathrm{Cu}$ NIST SRM 976) using different methods of mass bias correction and different $\mathrm{Cu} / \mathrm{Zn}$ concentration ratios

Table 5. Results of Zinc isotope determinations of Reference Isotopic Standards and Reference Materials. .96

Chapter 5: Zinc isotopes as tracers of waste from electroplating industries in coastal environments

Table 1. Data set of sediment cores, granite rocks and willemite ores samples......145

Table 2. Data set of mangrove superficial sediments and Laguncularia Racemosa leaf samples...................................................................148

Table 3. Data set of suspended particulate matter (SPM) samples................149

Chapter 6: Zinc isotopes compositions in bivalve molluscs tissues from a Brazilian estuary: implications for biomonitoring of metal contamination

Table 1. Suspended particulate matter (SPM) and water dataset..................168

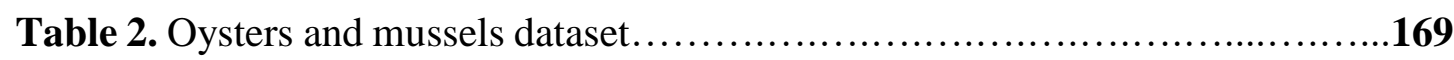




\section{Chapter 1}

\section{INTRODUCTION}

\subsection{The relevance of isotope biogeochemistry to environmental studies}

Over the past four decades, there have been advances in theoretical concepts of chemistry and physics accompanied by technological developments in mass spectrometry instrumentation. This has allowed higher precision and sensitivity in the measurement of radioactive and stable isotopes (Baskaran, 2011). Isotopic studies of bio- and geo-materials have provided qualitative and quantitative information about chemical, physical, geological, and biological processes useful for understanding the controls that govern the elemental cycles across the Earth's biogeospheres (Baskaran, 2011). This field of study has come to be known as isotope biogeochemistry.

The Earth's spheres undergo transformations due to climate changes (Biachi,2007). These systems furthermore experience large disturbances associated to anthropogenic activities, such as the releasing of contaminants into the environment, the exploitation of natural resources, and landscape alterations (Mason, 2001).

The study of isotopes in the Earth's systems becomes an important tool to elucidating the interactions and interrelations between elemental fluxes and natural compartments, either biotic or abiotic (Mason, 2011). Of special interest and relevance for health and environmental issues are the stable isotopic systems of (post-)transition metals (e.g. $\mathrm{Zn}, \mathrm{Cu}, \mathrm{Fe}, \mathrm{Mo}$ ). These elements are ubiquitous in the environment, normally occurring as trace metals (except Fe) (Adriano and Adriano, 2001). These elements are important micronutrients for living beings, play important economic and technological roles linked to industries, metallurgy, and mining, as well as present serious implications in environmental impacts triggered by these anthropogenic activities (Kossof et al., 2014; Ettler et al., 2016). Their cycles have been altered drastically due to their large anthropogenic remobilisation from deep reservoirs to the Earth's surface (for example, in ores, coal, and crude oil), which have lead to the contamination and enrichment of important natural compartments of soils, water and air (Mason, 2001). Depending on their bioavailability and speciation they can be 
incorporated to biogeosphere cycling, post-uptaking by microorganisms, plants and animals. Essential elements (e.g, $\mathrm{Zn}, \mathrm{Cu}, \mathrm{Mo}$ ) can play an important biological role, constituting basic components of enzymes and proteins (metalloproteins), and in biogeochemical reactions at the cellular level (Reilly, 2004). However, these same elements can present high toxicity to living organism in high concentrations (Adriano and Adriano, 2001; Sparks, 2005). Other transition metals do not present any biological function, and even in low concentrations can present high toxicity, as $\mathrm{Hg}$ and $\mathrm{Cd}$ (Adriano and Adriano, 2001; Sparks, 2005).

Stable isotopes of transition and post-transition metals are fractionated in nature or artificially during biogeochemical reactions, resulting in products or reservoirs isotopically distinct from the original substrate (Wiederhold, 2015). The understanding of the main factor of isotopic fractionation, and their magnitudes and mechanism (equilibrium vs. kinetics), open the possibility to use the isotope ratios of posttransition metals as powerful tracers to obtain important qualitative and quantitative information about sources, transport and fates of these elements (Wiederhold, 2015). Since such information are in the core of environmental contamination questions, these isotopes become a prominent tool to be applied for in environmental studies of biogeospheres.

Of the isotopic systems of transition and post-transition metals, $\mathrm{Zn}$ isotopes have been successfully employed in the discrimination and quantification of natural and anthropogenic sources including vehicle emissions and tire wear (Gioia et al., 2008; Thapalia et al., 2015), wastewaters and sewage (Chen et al., 2008; 2009), and mining and metallurgy byproducts (Dogolopova et al., 2006; Mattielli et al., 2006; Weiss et al., 2007; Sivry et al., 2008). The effectiveness of $\mathrm{Zn}$ isotopes is due to their nuclides undergoing strong isotopic fractionations in industrial processes (e.g metallurgy and combustion by high-temperature or electrolysis processes) resulting in fingerprints isotopically distinct for man-made materials and by-products from those found in nature (Kavner et al.; 2008; Sivry et al., 2008; Borrok et al.; 2010; Ochoa and Weiss, 2015; Thapalia et al., 2015; Yin et al.; 2016). In addition, low temperature biogeochemical processes such as adsorption on organic and inorganic solid surfaces, ligand exchange and complexation, precipitation, biological uptake, and intercellular transport can also fractionate the $\mathrm{Zn}$ isotopes, which is useful for distinguishing difference biogeochemical processes (Pichat et al., 2003; Stenberg et al., 2004; Weiss et al., 2004; Pokrovsky et 
al., 2005; Bermin et al., 2006; Gélabert et al., 2006; Balistrieri et al., 2008; Peel et al., 2009; Fujii et al.,2011; Jouvin et al., 2012; Little et al., 2014b; Kafantaris and Borrok, 2014; Matthies et al., 2014; Dekov et al., 2014; Coutaud et al., 2014; Zhao et al., 2014; Bryan et al., 2015; Veeramani et al., 2015).

However, when it comes to complex environments as coastal zones, the several factors involved on the $\mathrm{Zn}$ isotopic fractionation make the interpretation of their isotopic signatures a challenging task. The dynamic nature of estuaries and intertidal zones, characterized by strong chemical and physical gradients in the water and sediment properties, including $\mathrm{pH}$, potential redox, salinity and others, promote constant changes on solubility, mobility, bioavailability, and toxicity of trace metals. In addition, the pathways and sinks of these elements are conditioned by binding to organic and inorganic ligands, adsorption on colloids or surface solids (e.g, clay minerals, oxyhydroxides, organic matter), biogeochemical processes (e.g, microbiological activity and diagenesis), presence of multiple sources (urbanization, agriculture, energy production, industries) and climatic conditions (Biachi, 2007; Du Laing, 2009; Mason, 2013). In previous studies, in the Gironde fluvial-estuarine system (France), the Zn isotopic composition of suspended particulate matter (SPM) did not enable the separation between anthropogenic and natural sources, probably due to on-site remediation of the contamination source and the mixture with natural $\mathrm{Zn}$ in the fluvialestuarine continuum (Petit et al., 2015). In the dissolved phase, the large isotopic variation observed was attributed to adsorption processes in the estuary gradient and in the maximum turbidity zone (MTZ), rather than to sources contributions (Petit et al., 2015).

Zinc isotopes have also been determined in biological samples as tissues of bivalves mollusks intending to develop a new biomonitoring tool potentially capable of integrating sources, fates, and bioavailability information (Shiel et al.2012; Shiel et al.2013; Petit et al.2015). However, previous studies conducted with bivalves on the west coast in Canada and Gironde estuary, showed homogenous $\mathrm{Zn}$ isotopic signatures without correlation with anthropogenic sources neither in temporal or spatial analysis (Shiel et al.2012; Shiel et al.2013; Petit et al.2015). Thus, the applicability of Zn isotopes as tracer of sources and as a biomonitoring tool in coastal areas remains inconclusive. 
To improve our knowledge about metal transition and post-transition isotopes in coastal zones and mangroves, this thesis investigates the $\mathrm{Zn}$ isotope biogeochemistry in Sepetiba bay (Southern Brazil). This bay constitutes an ideal natural laboratory for evaluating the $\mathrm{Zn}$ isotopes as a tracer of metal contaminants in coastal areas, since it hosts important ecosystems of commercial and ecological interest - estuaries, mangroves and tidal flats- threaten by the metal contamination from an old electroplating activity and other anthropogenic diffuse sources (Molisani et al., 2004; Rodrigues et al., 2012). Previous geochemical studies performed in the last decades consolidated a good data base and an appreciable knowledge about the dispersion mechanisms of metal contaminants, which serve as important starting-point to sampling strategies and to interpret the $\mathrm{Zn}$ isotopic compositions of the natural samples collected in this complex system. (Molisani et al., 2004; Lacerda and Molisani, 2006).

This study is relevant because the trace metal contamination is supposedly more critical in coastal zones and mangrove since these areas are normally under greater anthropogenic pressure than inland. Coastal margins are inhabited by more than $60 \%$ of the world's population within $50 \mathrm{~km}$ of estuaries and play important roles for the supply and global transport via shipping of food, minerals, building materials and serves as strategical sites for transport and ore processing (Agardy and Alder, 2010). Such panorama induce major risks of metal contamination, threating important and unique, but vulnerable intertidal ecosystems, as mangroves, coral reefs, saltmarsh and seagrass which provide an ecological environment for diverse fauna and flora, sustaining a complex food web with intricate relationships between aquatic and terrestrial habitats (Agardy and Alder, 2010; Lewis, 2011; Bayen, 2012). As well as the releasing of metal contaminants into the environment, human activities have altered sediment flows in rivers due to erosion related to landscape use and dams, doubled the global average for nitrogen loading, and deteriorated the water quality by discharge of no treated sewage (Alcamo and Bennett, 2003). As a consequence, a series of dilemmas and trade-offs have arose between these important social and economic activities and the maintenance of the environmental quality. Such outcomes make it imperative to improve our understanding of trace metal biogeochemistry as well as to continue the development of tools capable of detecting changes in biogeochemical systems in order to auxiliary the prevention, monitoring, prediction of risks and remediation of impacted sites by metal contamination (Biachi, 2007). In this way, $\mathrm{Zn}$ isotopic signatures in natural samples such as sediments, water, leaves, and aquatic animals as bivalves are promising 
indicators of the environment quality and processes occurring in the determined sites of study.

\subsection{Objectives}

The main objective of this thesis was to investigate the applicability of $\mathrm{Zn}$ isotopes as a tracer of sources and biogeochemical processes, and as biomonitoring tool for metal contamination into coastal-zone ecosystems. The first step of this project was to set up a method for accurate and precise $\mathrm{Zn}$ isotopic measurements in environmental reference. Then, the stable isotopic composition of $\mathrm{Zn}$ was determined in several natural samples of Sepetiba bay (southeastern Brazil) and ore samples (from Vazante deposit, Minas Gerais, Brazil) refined in an old electroplating industry close the bay, in order:

i) To identify sources and sinks of anthropogenic $\mathrm{Zn}$;

ii) To reconstruct the temporal and spatial evolution of $\mathrm{Zn}$ contamination;

iii) To verify the influence of estuarine biogeochemical processes on the $\mathrm{Zn}$ isotopic signature during the element transport and deposition;

iv) To understand the effects of anthropogenic contamination on the mechanism of $\mathrm{Zn}$ uptake and tolerance of high-plant mangroves;

v) To unveil the meaning of bio-isotopic records of bivalves molluscs concerning the sources tracing and biogeochemical processes.

\subsection{Study area}

This study was conducted in Sepetiba Bay (southern Brazil), a microtidal estuary type lagoon, located $60 \mathrm{~km}$ west from Rio de Janeiro city (Fig.1). Sepetiba bay play a strategical role in the geo-economic center of Brazil, hosting a large population of metropolitan region of Rio de Janeiro City (estimated in 1,400000 inhabitants), an expressive industrial park, including the largest steel industry complex of American Latin and important harbor activity with three ports in operation. 

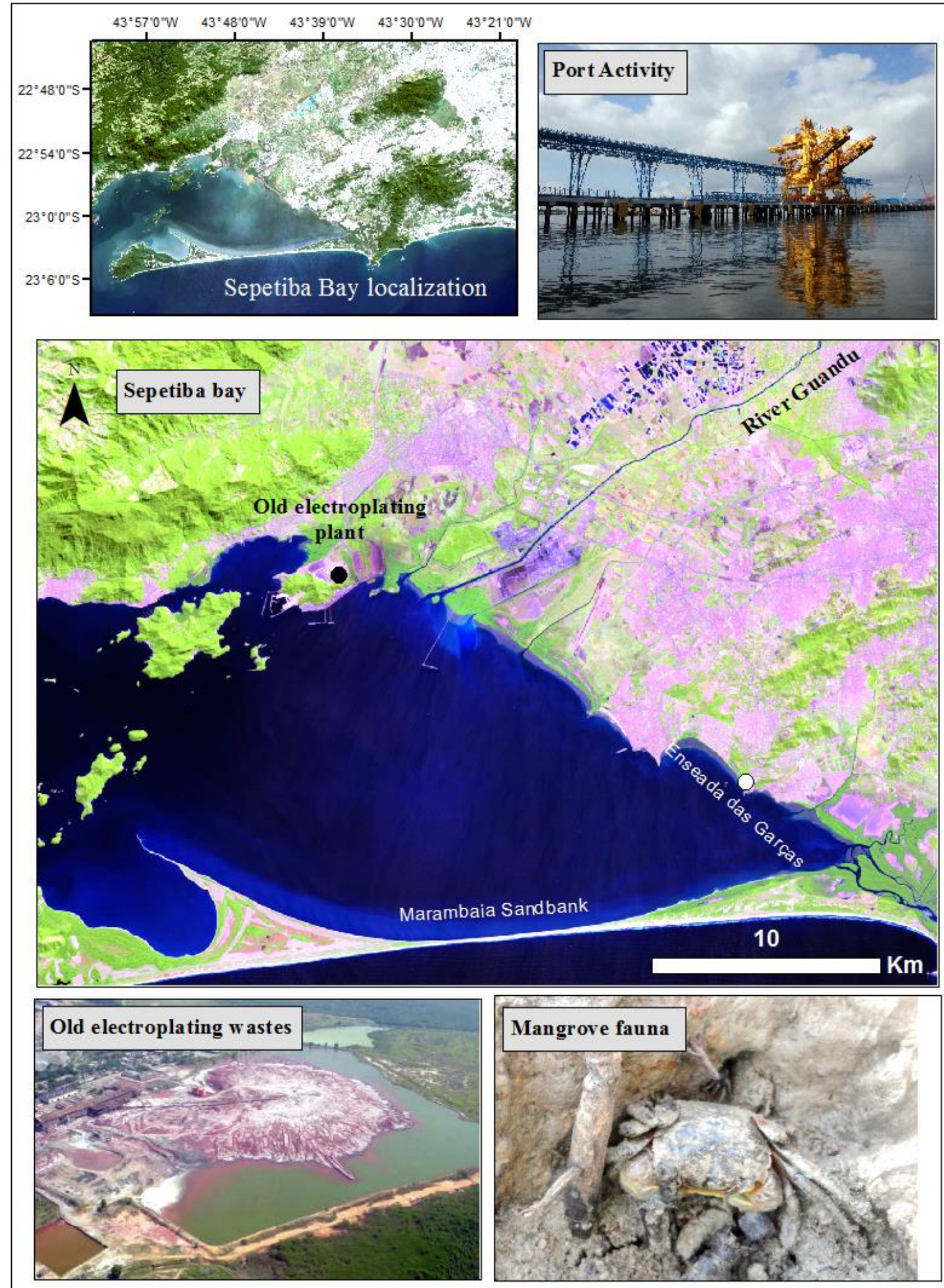

Fig.1. Localization of Sepetiba bay 
The water circulation in the bay is controlled by tides and the pattern of surface currents trends in a clockwise direction creating a preferential deposition area along the northern coast (Neto et al., 2006; Roncarati and Carelli, 2012). Water column depths ranging from 2 to $12 \mathrm{~m}$, except in navigation channels where the depth is greater (Molisani et al., 2004). Approximately 50\% of its area has water columns with depth less than $6 \mathrm{~m}$ (Molisani et al., 2004). The turnover time of the water mass was estimated at around 6 days with maximum current velocity at peak tides ranging from 50 to $75 \mathrm{~cm} . \mathrm{s}^{-1}$ (Molisani et al., 2004), being limited at the north and the east by the continent, and at the south by a sandbank (Fig.1).

The geological setting of the bay watershed is composed by Quaternary sediments spread in the low relief and granite-gneiss rocks in the ridge zones belong to the Proterozoic. The waters of three main rivers, Guandu, Guarda and Guandu-Mirim river, reach the bay by artificial channels that cross an industrial park (Molisani et al., 2006; Roncarati and Carelli, 2012). The São Francisco channel, with an annual flow of $6.5 \times 10^{9} \mathrm{~m}^{3}$, is responsible for over $86 \%$ of the total freshwater runoff flow. The fluvial waters dilute marine waters in the inner part of the bay resulting in salinities between 20 to 34 (Molisani et al., 2004).

The original hydrological features of this bay and its watershed have been affected since the 1950's when large scale works for the diversion of water and construction of reservoirs were performed in the main river of the bay (River Guandu), aimed at addressing the regional demand for water (Rodrigues et al., 2012). However, these changes on the drainage system resulted in an increase of sediment load and fresh water inputs into the lagoon system (Molisani et al., 2006). It is estimated there has been a rise of about $28 \%$ of sediment load delivered to the bay, an increase in sedimentation rates from 0.12 to $1.3 \mathrm{~cm}$ per year (Smoak and Patchineelam, 1999; Molisani et al., 2004; Marques et al., 2006; Molisani et al., 2006). Batimetric studies and tax sedimentation calculations have shown a continuous silting up in the inner bay, resulting in the expansion of tidal flats and the delta of São Francisco channel (Roncarati and Carelli, 2012).

In the 1960's, a large industrial park began to be implanted, inducing an unstructured, sprawled urbanization, drastic landscape alterations, sewage releasing into the environment, and metal contamination by metallurgic activities (Molisani et al., 2004). An electroplating plant started to operate in the Saco do Engenho close to the Itaguaí harbor (Fig.1). The zinc purification process used silicate ores (calamine- 
$\mathrm{Zn}_{2} \mathrm{SiO}_{3}(\mathrm{OH})_{2}$ and willemite- $\left.\mathrm{SiO}_{4} \mathrm{Zn}_{2}\right)$ acquired from Vazante (Minas Gerais, Brazil), the most important $\mathrm{Zn}$ deposit in Brazil. The ores were crushed and leached by sulfuric acid followed by filtration and purification of solution. Then the purified solution was carried to electrolytic cells where the zinc plates were produced. After this, the plates underwent smelting and casting processes (Barone, 1973). In 1996, the electroplating plant represented one of the three largest producers of zinc in Brazil with a total capacity of 60.000 tons per year (Barone, 1973).

The low production efficiency (75 to $90 \%$ ) in the employed technological process have been appointed as responsible factor for high production of wastes (Barcellos, 1994).

The electroplating wastes (estimated to about 600,000 tons, and containing about 200 tons of $\mathrm{Cd}$ and 50.000 tons of $\mathrm{Zn}$ ) were disposed in an area of $40 \mathrm{~m}^{2}$ adjacent to the small marine channel Saco do Engenho (Fig.1). Rainfalls continuously leached the waste tailing to this channel and into the bay (Barcellos, 1991). To reduce the transport of these materials to the coastal area a dike was built between the bay and the tailing disposal site in 1984. However its rupture in 1996 caused a large input of contaminants to the surrounding bay area. In 1998 the industrial activities ceased (Molisani et al., 2004).

Several studies identified high metal concentrations in biota and sediment compartments of Sepetiba Bay, particularly for Zn (Barcelos et al., 1991). Zinc content in sediments (Pellegati et al., 2001; Wasserman et al., 2001), oysters (Rebelo et al.2003) and brown algaes (Amado Filho et al., 1999) exceed 2000, 80000 and $800 \mu$ g.g- $^{1}$ respectively. Other toxic elements also have been reported with concentrations reaching $396 \mu \mathrm{g} \cdot \mathrm{g}^{-1}$ for Cd (Lacerda et al., 1988), $360 \mu \mathrm{g} \cdot \mathrm{g}^{-1}$ for As (Magalhães and Pfeiffer, 1994) and $460 \mu \mathrm{g}^{-\mathrm{g}^{-1}}$ for $\mathrm{Pb}$ (Lacerda et al.1987). Despite the end of electroplating refining of $\mathrm{Zn}$, high metal concentrations have been reported even ten years later (Marques et al.2006; Gomes et al.2009; Patchineelam et al.2011; Ribeiro et al.2013) possibly due to the continuous leaching of wastes and remobilization of sediments from the hot spot of contamination, Saco do Engenho, to across the bay. In 2012, the tailings of wastes was removed from the bay, leading to a probable decrease of metal inputs in the lagoon system. However no published study has reported the actual levels and tendencies in the metal contamination.

Recently, the Itaguaí port was expanded and adapted to become a Hub Port, capable of receiving big ships transporters of (cape size) bulk cargos like ores, charcoal, 
sulfur, and aluminium. A third port, Porto Sudeste, started its operation in 2015, with the capability to handle more than 50 million tonnes per year of iron ores and an expansion capacity prevised for up to 100 million tonnes per year. Due to traffic of large ships, major dredging actions have been performed to deepen the water column, leading to resuspension of sediment with potential remobilization of contaminants (Rodrigues et al., 2012).

Sediment mobilization is the main transport of metal and contaminants in Sepetiba bay (Lacerda et al., 1987). The complex hydrodynamic of the system and sediment re-suspension lead to large transport of suspended particles before its deposition promoting the remobilization and the dispersion of the contaminants along different zones of the bay (Barcellos, 1997). Computational modeling of the lagoon hydrodynamics shows a trend of fine sediments deposition along the northeastern coastal area of the bay where the tidal flats and mangroves acts as sinks of contaminants (Montezuma, 2013). In the mangroves and tidal flats sediments, the anoxic and organic matter-rich conditions result in the production of hydrogen sulfide $\left(\mathrm{H}_{2} \mathrm{~S}\right)$ in sediment pore waters and the formation of insoluble metallic sulfides and complexes with organic matter (Lacerda et al.1994; Machado et al.2008; Andrade et al., 2012). This leads to the immobilization of $\mathrm{Zn}$ and other toxic metals $(\mathrm{Cd}, \mathrm{Cu}, \mathrm{Ni}$ and $\mathrm{Pb})$ along the bay area (Andrade et al.2012; Ribeiro et al. 2013). 


\subsection{Thesis structure}

Apart from this introductory chapter, this thesis is composed of the following Chapters:

Chapter 2 - The trace metal biogeochemistry in coastal zones and mangroves: This chapter presents a brief literature review about the aspects of trace metal biogeochemistry cycling in coastal zones, in particular in estuaries, mud flats and intertidal zones. The chapter describes the sources, mechanism of transport and diagenetic processes in the sediment-water interface.

Chapter 3 - Zinc stable isotope biogeochemistry: a review: In paper format, this chapter provides a conceptual framework of main principles of isotopic fractionation, applications and important findings of the $\mathrm{Zn}$ isotope biogeochemistry.

Chapter 4 - Ion exchange chromatography and mass bias correction for accurate and precise $\mathrm{Zn}$ isotope ratio measurements in environmental reference materials by MC-ICP-MS: Here is presented the manuscript published as a paper in the Journal of the Brazilian Chemical Society (DOI: 10.5935/0103-5053.20160167). This paper discusses the $\mathrm{Zn}$ isotope methodology stablished in this work.

Chapter 5- Zinc isotopes as tracers of waste from electroplating industries in coastal environments: This chapter includes the manuscript submitted to Chemical Geology journal and accepted with corrections. It presents the results and discussion of sediments, rocks, leaves and ores concerning the application of $\mathrm{Zn}$ isotopes as a tracer of electroplating wastes in coastal environments and biogeochemical processes in mangroves.

Chapter 6- Zinc isotopes composition in bivalves mollusc tissues from a Brazilian estuary: implications for biomonitoring of metal contamination: In this chapter, it is presented a manuscript in preparation, where is discussed the $\mathrm{Zn}$ isotopic information in mollusc bivalves for biomonitoring studies.

Chapter 7- Summary and Conclusions: The main findings and conclusions of this project are presented in this chapter. 


\section{References}

Alcamo J. and Bennett E. Ecosystems and human well-being. Island Press, Washington, DC.

Agardy T. and Alder J.(2003) Coastal Systems (chapter 19) In: Ecosystems and human well-being(eds. Alcamo J. and Bennett E.). Island Press, Washington, DC.

Adriano D. and Adriano D. (2001) Trace elements in terrestrial environments. Springer, New York.

Andrade R., Sanders C., Boaventura G. and Patchineelam S. (2012) Pyritization of trace metals in mangrove sediments. Environ Earth Sci 67, 1757-1762.

Amado Filho G., Andrade L., Karez C., Farina M. and Pfeiffer W. (1999) Brown algae species as biomonitors of $\mathrm{Zn}$ and $\mathrm{Cd}$ at Sepetiba Bay, Rio de Janeiro, Brazil. Marine Environmental Research 48, 213-224.

Barone, R.H.T.1973. Perfil analítico do zinco. Ministério das Minas e Energia. Departamento Nacional da Produçao Mineral. Bolteim n²6. Rio de Janeiro, Brasil.

Bayen S. (2012) Occurrence, bioavailability and toxic effects of trace metals and organic contaminants in mangrove ecosystems: A review. Environment International 48, 84-101.

Baskaran M. (2011) Handbook of environmental isotope geochemistry. Springer, Berlin.

Bermin J., Vance D., Archer C. and Statham P. (2006) The determination of the isotopic composition of $\mathrm{Cu}$ and $\mathrm{Zn}$ in seawater. Chemical Geology 226, 280-297.

Barcellos C. and Lacerda L. (1994) Cadmium and zinc source assessment in the Sepetiba Bay and basin region. Environmental Monitoring and Assessment 29, 183-199.

Barcellos C., Rezende C. and Pfeiffer W. (1991) Zn and Cd production and pollution in a Brazilian coastal region. Marine Pollution Bulletin 22, 558-561.

Bianchi T. (2007) Biogeochemistry of estuaries.Oxford University Press, Oxford.

Borrok D., Gieré R., Ren M. and Landa E. (2010) Zinc Isotopic Composition of Particulate Matter Generated during the Combustion of Coal and Coal + Tire-Derived Fuels. Environmental Science \& Technology 44, 9219-9224.

Bryan A., Dong S., Wilkes E. and Wasylenki L. (2015) Zinc isotope fractionation during adsorption onto Mn oxyhydroxide at low and high ionic strength. Geochimica et Cosmochimica Acta 157, 182-197.

Chen J., Gaillardet J. and Louvat P. (2008) Zinc Isotopes in the Seine River Waters, France: A Probe of Anthropogenic Contamination. Environmental Science \& Technology 42, 6494-6501.

Chen J., Gaillardet J., Louvat P. and Huon S. (2009) Zn isotopes in the suspended load of the Seine River, France: Isotopic variations and source determination. Geochimica et Cosmochimica Acta 73, 40604076.

Coutaud A., Meheut M., Viers J., Rols J. and Pokrovsky O. (2014) Zn isotope fractionation during interaction with phototrophic biofilm. Chemical Geology 390, 46-60.

Dekov V., Vanlierde E., Billström K., Garbe-Schönberg C., Weiss D., Gatto Rotondo G., Van Meel K., Kuzmann E., Fortin D., Darchuk L. and Van Grieken R. (2014) Ferrihydrite precipitation in groundwater-fed river systems (Nete and Demer river basins, Belgium): Insights from a combined Fe-Zn-Sr-Nd-Pb-isotope study. Chemical Geology 386, 1-15.

Du Laing G., Rinklebe J., Vandecasteele B., Meers E. and Tack F. (2009) Trace metal behaviour in estuarine and riverine floodplain soils and sediments: A review. Science of The Total Environment 407, 3972-3985.

Ettler V., Quantin C. and Kersten M. (2016) Applied Geochemistry special issue on Environmental impacts of mining and smelting. Applied Geochemistry 64, 1.

Fujii T., Moynier F., Pons M. and Albarède F. (2011) The origin of Zn isotope fractionation in sulfides. Geochimica et Cosmochimica Acta 75, 7632-7643.

Gélabert A., Pokrovsky O., Viers J., Schott J., Boudou A. and Feurtet-Mazel A. (2006) Interaction between zinc and freshwater and marine diatom species: Surface complexation and Zn isotope fractionation. Geochimica et Cosmochimica Acta 70, 839-857.

Gioia S., Weiss D., Coles B., Arnold T. and Babinski M. (2008) Accurate and Precise Zinc Isotope Ratio 
Measurements in Urban Aerosols. Analytical Chemistry 80, 9776-9780.

Gomes, F. de C., Godoy J., Godoy M., Lara de Carvalho Z., Tadeu Lopes R., Sanchez-Cabeza J., Drude de Lacerda L. and Cesar Wasserman J. (2009) Metal concentrations, fluxes, inventories and chronologies in sediments from Sepetiba and Ribeira Bays: A comparative study. Marine Pollution Bulletin 59, 123-133.

Kafantaris F. and Borrok D. (2014) Zinc isotope fractionation during surface adsorption and intracellular incorporation by bacteria. Chemical Geology 366, 42-51

Kavner A., John S., Sass S. and Boyle E. (2008) Redox-driven stable isotope fractionation in transition metals: Application to Zn electroplating. Geochimica et Cosmochimica Acta 72, 1731-1741

Kossoff D., Dubbin W., Alfredsson M., Edwards S., Macklin M. and Hudson-Edwards K. (2014) Mine tailings dams: Characteristics, failure, environmental impacts, and remediation. Applied Geochemistry 51, 229-245.

Lacerda LD, Koudstaal R, Bower BT (1988) Sepetiba Bay management study: draft workplan. The International Federation of Institutes for Advanced Study, IFIAS Research Program on Coastal Resources Management, Maastricht.

Lacerda L. and Molisani M. (2006) Three decades of Cd and Zn contamination in Sepetiba Bay, SE Brazil: Evidence from the mangrove oyster Crassostraea rhizophorae. Marine Pollution Bulletin 52, 974-977.

Lacerda, L. D. and Rezende, C. E. (1987). Metal geochemistry in mangrove sediments. Simposio sobre Ecossistemas Costeiros da Costa Sul e Sudeste do Brasil. São Paulo: Academia de Ciências do Estado de São Paulo, 123-131 p

Langston W. and Bebianno M. (1998) Metal metabolism in aquatic environments., Chapman \& Hall, London.

Leal Neto A., Legey L., González-Araya M. and Jablonski S. (2006) A System Dynamics Model for the Environmental Management of the Sepetiba Bay Watershed, Brazil. Environmental Management $38,879-888$

Lewis M., Pryor R. and Wilking L. (2011) Fate and effects of anthropogenic chemicals in mangrove ecosystems: A review. Environmental Pollution 159, 2328-2346.

Little S., Vance D., Walker-Brown C. and Landing W. (2014) The oceanic mass balance of copper and zinc isotopes, investigated by analysis of their inputs, and outputs to ferromanganese oxide sediments. Geochimica et Cosmochimica Acta 125, 673-693.

Marques A., Monna F., da Silva Filho E., Fernex F. and Fernando Lamego Simões Filho F. (2006) Apparent discrepancy in contamination history of a sub-tropical estuary evaluated through $210 \mathrm{~Pb}$ profile and chronostratigraphical markers. Marine Pollution Bulletin 52, 532-539.

Magalhães V. F. de, and Pfeiffer W. (1995) Arsenic concentration in sediments near a metallurgical plant (Sepetiba Bay, Rio de Janeiro, Brazil). Journal of Geochemical Exploration 52, 175-181.

Mattielli N., Rimetz J., Petit J., Perdrix E., Deboudt K., Flament P. and Weis D. (2006) Zn-Cu isotopic study and speciation of airborne metal particles within a $5-\mathrm{km}$ zone of a lead/zinc smelter. Geochimica et Cosmochimica Acta 70, A401.

Matthies R., Krahé L. and Blowes D. (2014) Zinc stable isotope fractionation upon accelerated oxidative weathering of sulfidic mine waste. Science of the Total Environment 487, 97-101.

Molisani M., Kjerfve B., Silva A. and Lacerda L. (2006) Water discharge and sediment load to Sepetiba Bay from an anthropogenically-altered drainage basin, SE Brazil. Journal of Hydrology 331, 425433.

Mason R.(2013) Trace metals in aquatic systems. Willey-Blackwell, Oxford.

Montezuma P.N. (2012) Análise de prováveis fatores causadores do processo de assoreamento na Baía de Sepetiba-RJ. In: Bacia hidrográfica dos Rios Guandu, da Guarda e Guandu-Mirim. INEA, Rio de Janeiro.

Ochoa Gonzalez R. and Weiss D. (2015) Zinc Isotope Variability in Three Coal-Fired Power Plants: A Predictive Model for Determining Isotopic Fractionation during Combustion. Environmental Science \& Technology 49, 12560-12567.

Patchineelam S., Sanders C., Smoak J., Zem R., Oliveira G. and Patchineelam S. (2011) A historical 
evaluation of anthropogenic impact in coastal ecosystems by geochemical signatures. J. Braz. Chem. Soc. 22, 120-125.

Peel K., Weiss D. and Siggc L. (2009) Zinc isotope composition of settling particles as a proxy for biogeochemical processes in lakes: Insights from the eutrophic Lake Greifen, Switzerland. Limnol. Oceanogr. 54, 1699-1708.

Pellegatti F., Figueiredo A. and Wasserman J. (2001) Neutron Activation Analysis Applied to the Determination of Heavy Metals and Other Trace Elements in Sediments from Sepetiba Bay (RJ), Brazil. Geostandards and Geoanalytical Research 25, 307-315.

Petit J., Schäfer J., Coynel A., Blanc G., Chiffoleau J., Auger D., Bossy C., Derriennic H., Mikolaczyk M., Dutruch L. and Mattielli N. (2015) The estuarine geochemical reactivity of Zn isotopes and its relevance for the biomonitoring of anthropogenic $\mathrm{Zn}$ and $\mathrm{Cd}$ contaminations from metallurgical activities: Example of the Gironde fluvial-estuarine system, France. Geochimica et Cosmochimica Acta 170, 108-125.

Pichat S., Douchet C. and Albarède F. (2003) Zinc isotope variations in deep-sea carbonates from the eastern equatorial Pacific over the last $175 \mathrm{ka}$. Earth and Planetary Science Letters 210, 167-178.

Pokrovsky O., Viers J. and Freydier R. (2005) Zinc stable isotope fractionation during its adsorption on oxides and hydroxides. Journal of Colloid and Interface Science 291, 192-200.

Rebelo M. de F., Clara Rebouças do Amaral M. and Chritstian Pfeiffer W. (2003) High Zn and Cd accumulation in the oyster Crassostrea rhizophorae, and its relevance as a sentinel species. Marine Pollution Bulletin 46, 1354-1358.

Ribeiro A., Figueiredo A., Santos J., Dantas E., Cotrim M., Cesar Lopes Figueira R., V. Silva Filho E. and Cesar Wasserman J. (2013) Combined SEM/AVS and attenuation of concentration models for the assessment of bioavailability and mobility of metals in sediments of Sepetiba Bay (SE Brazil). Marine Pollution Bulletin 68, 55-63.

Rodrigues, M.A.C.; Silvia, D.P; Santos, S.B. dos.(2012). Baía de Sepetiba: Estado da Arte. Rio de Janeiro. Corbã.

Roncarati, H. and Carelli; S.G (2012). Consideraçoes sobre estado da arte dos processos geológicos cenozóicos atuantes na baía de Sepeitba. In Baía de Sepetiba: Estado da Arte. Rio de Janeiro: Corbã.

Sivry Y., Riotte J., Sonke J., Audry S., Schafer J., Viers J., Blanc G., Freydier R. And Dupre B. (2008) Zn isotopes as tracers of anthropogenic pollution from Zn-ore smelters The Riou Mort-Lot River system. Chemical Geology 255, 295-304.

Smoak J.M, Patchineelam S.R (1999) Sediment mixing and accumulation in a mangrove ecosystem evidence from ${ }^{210} \mathrm{~Pb},{ }^{234} \mathrm{Th}$ and ${ }^{7} \mathrm{Be}$. Mangroves Salt Marshes 3:17-27

Stenberg A., Andrén H., Malinovsky D., Engström E., Rodushkin I. and Baxter D. (2004) Isotopic Variations of Zn in Biological Materials. Analytical Chemistry 76, 3971-3978.

Szynkiewicz A. and Borrok D. (2016) Isotope variations of dissolved $\mathrm{Zn}$ in the Rio Grande watershed, USA: The role of adsorption on $\mathrm{Zn}$ isotope composition. Earth and Planetary Science Letters 433, 293-302.

Thapalia A., Borrok D., Van Metre P. and Wilson J. (2015) Zinc Isotopic Signatures in Eight Lake Sediment Cores from Across the United States. Environmental Science \& Technology 49, 132-140.

Sparks D. (2005) Toxic Metals in the Environment: The Role of Surfaces. Elements 1, 193-197.

Shiel A., Weis D., Cossa D. and Orians K. (2013) Determining provenance of marine metal pollution in French bivalves using $\mathrm{Cd}, \mathrm{Zn}$ and $\mathrm{Pb}$ isotopes. Geochimica et Cosmochimica Acta 121, 155-167

Shiel A., Weis D. and Orians K. (2012) Tracing cadmium, zinc and lead sources in bivalves from the coasts of western Canada and the USA using isotopes. Geochimica et Cosmochimica Acta 76, 175190.

Yin N., Sivry Y., Benedetti M., Lens P. and van Hullebusch E. (2016) Application of Zn isotopes in environmental impact assessment of $\mathrm{Zn}-\mathrm{Pb}$ metallurgical industries: A mini review. Applied Geochemistry 64, 128-135.

Wasserman J., Figueiredo A., Pellegatti F. and Silva-Filho E. (2001) Elemental composition of sediment cores from a mangrove environment using neutron activation analysis. Journal of Geochemical 
Exploration 72, 129-146.

Weiss D., Mason T., Zhao F., Kirk G., Coles B. and Horstwood M. (2004) Isotopic discrimination of zinc in higher plants. New Phytologist 165, 703-710.

Weiss D., Rausch N., Mason T., Coles B., Wilkinson J., Ukonmaanaho L., Arnold T. and Nieminen T. (2007) Atmospheric deposition and isotope biogeochemistry of zinc in ombrotrophic peat. Geochimica et Cosmochimica Acta 71, 3498-3517.

Wiederhold J. (2015) Metal Stable Isotope Signatures as Tracers in Environmental Geochemistry. Environmental Science \& Technology 49, 2606-2624

Zhao Y., Vance D., Abouchami W. and de Baar H. (2014) Biogeochemical cycling of zinc and its isotopes in the Southern Ocean. Geochimica et Cosmochimica Acta 125, 653-672. 


\section{Chapter 2}

\section{THE TRACE METAL BIOGEOCHEMISTRY IN COASTAL ZONES AND MANGROVES}

In coastal zones, the boundary between land and sea can take different forms including rocky cliffs, banks, sandy beaches, dunes, coral reef systems, lagoons, estuaries, intertidal zones or water wetlands as mangrove forests, marshes, etc. This chapter focuses on the biogeochemistry of trace metals in estuaries and intertidal sediments because of their ecological relevance concerning anthropogenic impacts and their potential risks to the biota and human health (Jickells and Rae, 1997; Alcamo and Bennett, 2003). In addition, the use of bivalve molluscs as biomonitors of metal contamination is also discussed.

Estuaries areas where the fresh water of rivers meets the salt water of oceans - are highly productive, dynamic, ecologically critical to other marine systems, and valuable to man (Agardy and Alder, 2010). Worldwide, some 1,200 major estuaries have been identified and mapped, yielding a total digitized area of approximately $500,000 \mathrm{Km}^{2}$. These aquatic systems are particularly important as nursery areas for fisheries and other species, and form one of the strongest linkages between coastal, marine, and freshwater systems and the ecosystem services they provide (Beck et al. 2001). Estuaries represent the main route in the transference of terrigenous and anthropogenic materials from watersheds to coastal zones and the ocean. Along the estuarine pathway, chemical compounds including trace metals, can undergo several biogeochemical processes that influence their fate and toxicity (Bianchi, 2007). The knowledge of the biogeochemistry of estuaries is, therefore, imperative to elucidate the metal cycling in the coastal zones either in a regional or global context (Bianchi, 2007).

Mangrove and tidal flats are ecosystems developed in intertidal zones. They present large biological diversity and productivity, contributing to the support of food webs with intricate relationships with neighboring habitats (Bayen, 2012). These ecosystems can act as a filter for chemical compounds in the interface between terrestrial and coastal areas, receiving and trapping potentially deleterious anthropogenic contaminants within its organic rich sediments (Machado and Lacerda, 2004). The high 
capabilities of retention within mangrove sediments contribute to the reduction of the metal transfer to adjacent coastal areas, however, depending on the changes in biogeochemical conditions, these elements can become bioavailable to plants and animals (MacFarlane et al., 2000). In the year 2000, the total area of mangroves in the world was estimated to $137,760 \mathrm{~km}^{2}$ in 118 countries (Giri et al., 2010), covering between 110,000 and $200,000 \mathrm{~km}^{2}$ along more than $70 \%$ of the world's tropical and subtropical coastlines (FAO, 2007; Spalding et al., 1997; Wilkie and Fortune, 2003). In this way, mangroves worldwide have a great influence on the metal dynamics of coastal areas (Fig.2).

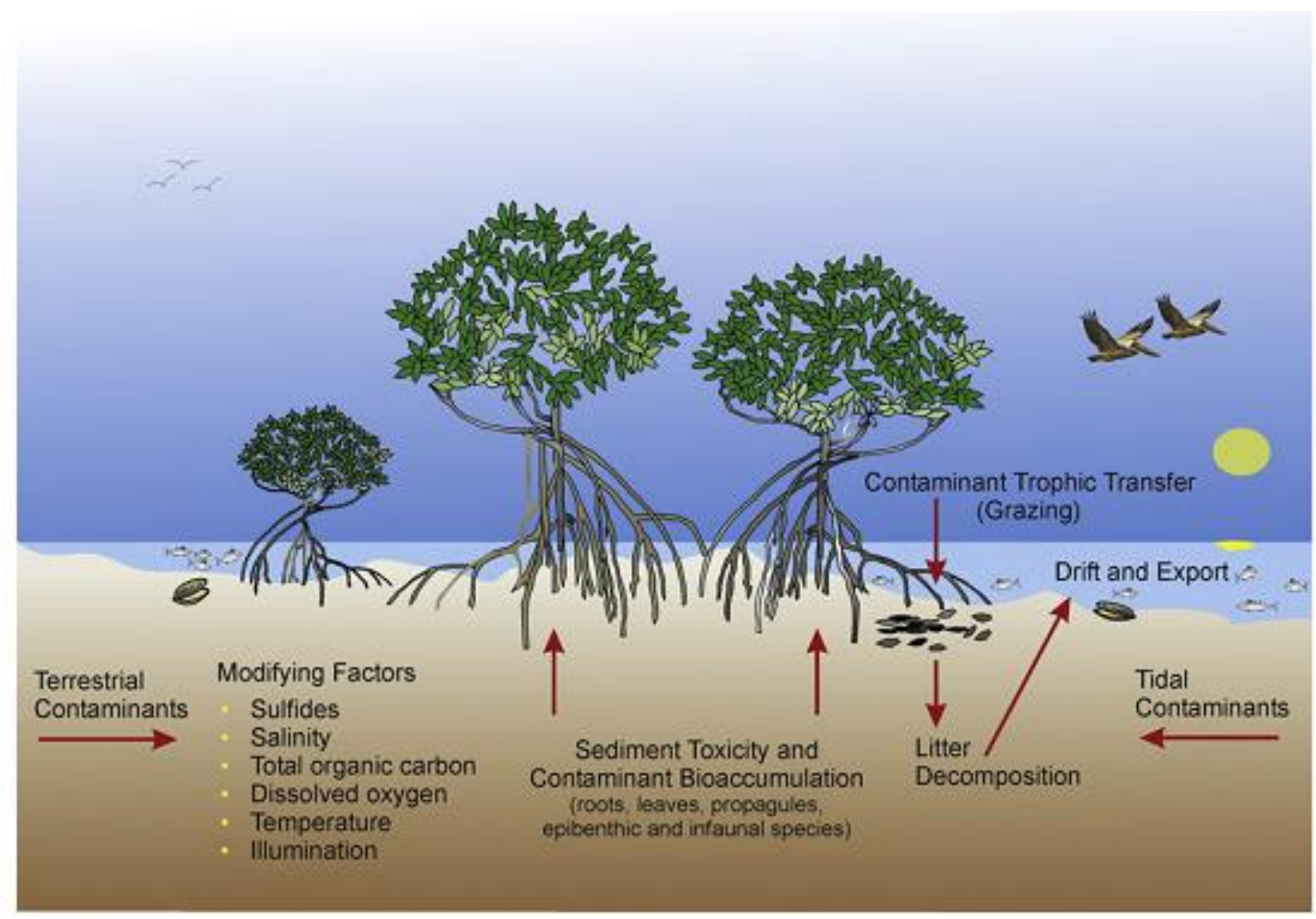

Fig.2. Pathways for contaminant toxicity and bioaccumulation on mangrove ecosystems. Source: Lewis et al., 2011.

\subsection{Trace metal in the estuarine system: sources, transport and fates.}

Estuaries are common features in the continent-ocean interface and can be defined as " $\mathrm{a}$ semi-enclosed coastal body of water that extends to the effective limit of tidal influence, within which sea water entering from one or more free connections with the open sea, or any other saline coastal body of water, is significantly diluted with fresh water derived from land drainage, and can sustain euryhaline biological species from either, part or the 
whole of their life cycle" (Perillo, 1995). They present internal water circulation, tidal cycles, sediment resuspension events, exchange of water flow with adjacent marshes, mangroves and other ecosystems, and receive river and groundwater discharges and atmospheric inputs (Leonard and Luther, 1995).

Estuaries are highly dynamic systems, characterized by strong chemical and physical gradients and multiple sources (Bianchi, 2007). This results in complex trace metal cycling, conditioned by a combination of factors such as redox conditions, ionic strength, abundance of adsorbing surfaces, $\mathrm{pH}$, primary activity, coagulation, flocculation, sediment resuspension, tidal cycles, tidal currents and post depositional processes in sediments such as diagenesis (Millward, 1995; Wen et al., 1999; Bianchi, 2007).

Trace metals release into estuaries from natural process such as weathering and erosion of rocks and soils, volcanic activity, or anthropic sources including industrial, agricultural and domestic activities present in the drainage basin (Adriano and Adriano, 2001; Sparks, 2005). They can reach in the estuaries system via the atmosphere, groundwater or via fluvial pathways, of which the latter constitutes the main input (Mason, 2013). Once they have entered the fluvial-estuarine waters, they are transformed by biogeochemical processes and distributed under various physico-chemical forms (Fig.3), i.e. particulate $(0.45 \mathrm{~mm})$, colloidal $(1 \mathrm{~nm}-0.45 \mathrm{~mm})$ and dissolved metal species $(<1 \mathrm{~nm})$. Overall, anthropogenic contributions and formation of stable complexes with dissolved organic matter enhance the metal concentrations in the dissolved phase (Windom and Smith 1985; Tercier-Waeber and Taillefert, 2008; Mason, 2013). In addition, as trace metals are strongly associated with particles, the total concentration in the dissolved phase is a strong function of the suspended particulate material loading (Tuner and Millward, 2002; Mason, 2013).

In the dissolved phase, the metal can occur in three main forms: free hydrated ion, inorganic and organic complexes. The five inorganic ligands of primary importance in natural waters are $\mathrm{F}^{-}, \mathrm{Cl}^{-}, \mathrm{SO}_{4}{ }^{2-}, \mathrm{OH}^{-}, \mathrm{HCO}_{3}{ }^{-}, \mathrm{CO}_{3}{ }^{2-}, \mathrm{HPO}_{3}{ }^{2-}, \mathrm{NH}_{3}$ and, in anoxic waters, $\mathrm{HS}^{-}$and $\mathrm{S}_{2}$ (Parametrix, 1995). Organic ligands include natural organic matter, often dominated by humic substances (decomposing organic matter), which present organic functional groups (carboxylic, amino, sulfidi and phenolic) as binding sites (Paquin et al.2002). The formation of complexes in natural waters can affect the rates of redox processes, mineral solubility and biochemical availability. The effect of these ligands on 
metal bioavailability is often seen as a direct consequence of dissolved ligand competition with binding sites on gills or gut surface for the free metal ion. They may also modify metal transport across membranes through several mechanisms, including competition with surface ligand sites, modification of lipid solubility, precipitation of complexes, and modification of biological processes (e.g., osmoregulation, respiration, excretion) (Newman and Jagoe, 1994). The free (hydrate)-metal ions are recognized as the most bioavailable and toxic form, while inorganic and organic complexes can also be potentially bioavailable presenting some toxicity (Anderson et al., 1984; Milero, 2001).

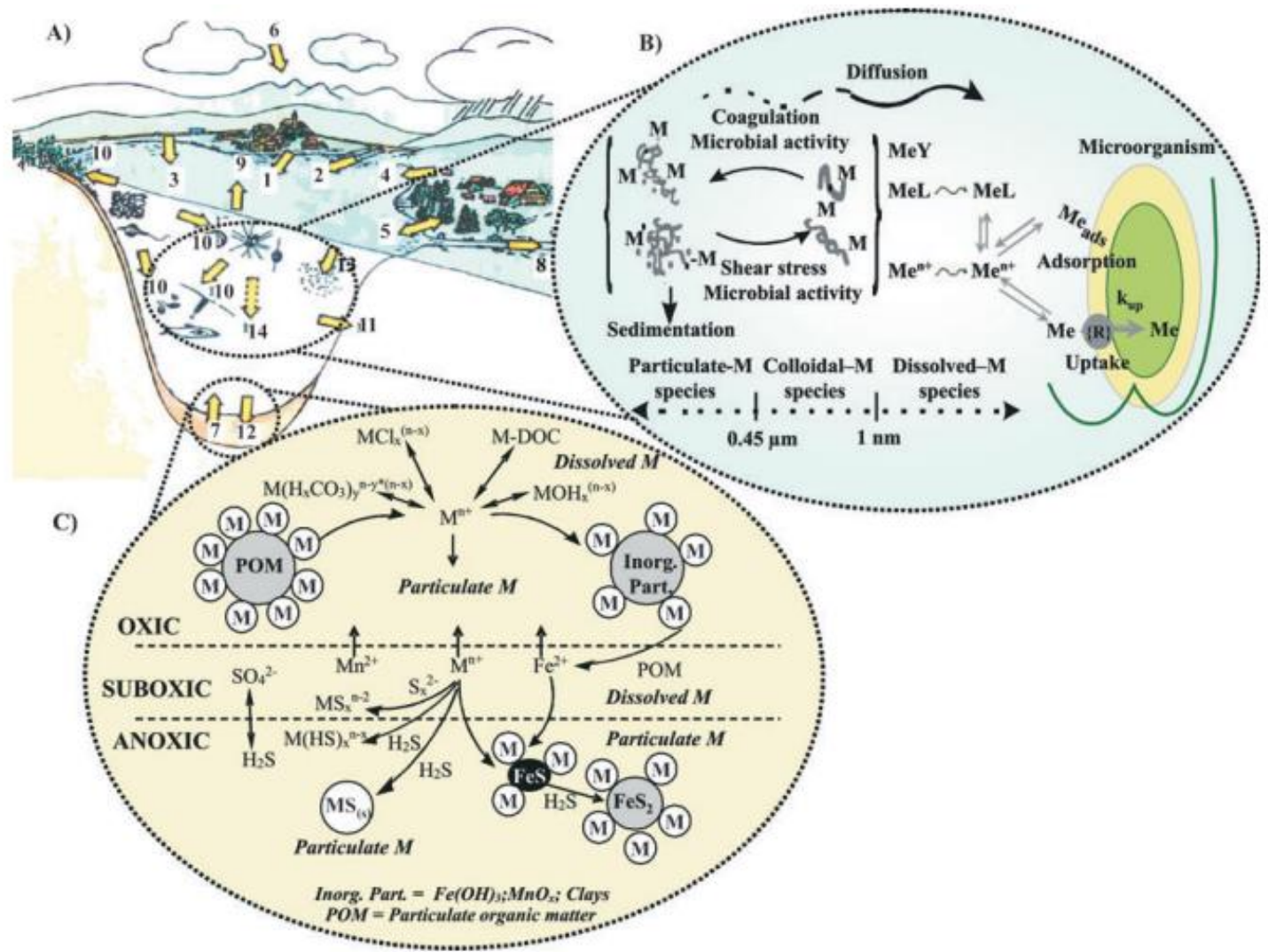

Fig.3. Schematic representation of the different fluxes of trace metals between aquatic ecosystems (A), with emphasis on the geochemical processes regulating metal cycling in the water column (B) and in sediments (C). Trace metals may reach aquatic systems via: (1) waste water treatment; (2) tributaries, surface runoff from (3) roads and (4) agricultural lands and soils, (5) exchange with groundwater, (6) atmospheric deposition, (7) release from sediments; they may be eliminated through: (8) discharge in effluents, (9) evaporation, (10) uptake by surrounding vegetation and organisms, (11) infiltration into subterranean waters, (12) reaction in the upper sediment layers, (13) adsorption by suspended matter, and (14) sedimentation. Source: Tercier-Waeber and Taillefert, 2008.

The distribution between the dissolved and particulate phase of trace metals is a function of the competition between the dissolved ligands and the sorption processes on the surface binding sites of materials sorbents. In particular, the finest particles and the colloidal fractions of inorganic (clay minerals, metal oxides and oxyhydroxides and sulfides) and biogenic materials (bacteria, fungi, protozoans, plankton, faecal matter, 
marine and terrestrial plant debris, proteins, carbohydrates, lipids and pigments) play a pivotal role on the sorption processes of trace metal due their significant surface area and surface charge (Oades, 1989; Mayer, 1994a,b; Aufdenkampe et al., 2001; Turner and Millward, 2002). Special attention have been given to the Fe and Mn-oxyhidroxides because they are found in a wide variety of geological settings, nearly ubiquitous in sediments and soils (Heyden and Roychoudhury, 2015). The interaction of these metals with even small amounts of Fe and Mn-oxyhidroxides has been reported to decrease the dissolved metal concentration by several orders of magnitude, and therefore, they constitute an important repository for a wide variety of metals such as $\mathrm{Cu}, \mathrm{Co}, \mathrm{Cd}, \mathrm{Zn}$, $\mathrm{Ni}, \mathrm{Sn}, \mathrm{Pb}, \mathrm{Ca}, \mathrm{Fe}, \mathrm{Ra}, \mathrm{Hg} \mathrm{U}, \mathrm{Pu}, \mathrm{Po}, \mathrm{As}, \mathrm{Se}$ and Th (Young and Harvey, 1992; Post, 1999, MERAG, 2007)

A general configuration of ions or complexes on a solid surface can be described by the diffuse double layer (DDL) model. At solid- solution interfaces, the counter-ions (ions with a charge opposite that of the solid surface) and co-ions (ions with a charge of the same sign as that of the surface) are diffusely distributed in the double layer, with counter-ions increasing in concentration toward the solid surface and co-ions increasing in concentration away the solid surface. The high concentration of counter ions close to clay surface gradually reduces, and reaches equilibrium concentration at a distance away from clay surfaces. For co-ions, concentration increases with distance from clay surfaces (Brown and Calas, 2011). Fig.4 illustrates schematically the distribution of counter-ions and co-ions on a particle surfaces.

The surface charge can be permanent, resulting from ionic substitution in the clay structure. Or the charge can be $\mathrm{pH}$ dependent, varying between negative, neutral or positive charges as $\mathrm{pH}$ increases or decreases. Clay minerals such as montmorillonite and vermiculite exhibit constant surface charge independent of $\mathrm{pH}$ variations. Clay minerals such as kaolinite and $\mathrm{Al}$ and Fe-oxides, organic matter and amorphous $\mathrm{Fe}$ and $\mathrm{Mn}-$ oxihydroxides reveal varying surface charge with $\mathrm{pH}$, becoming positively charged with the protonation of functional groups at low $\mathrm{pH}$ and negatively charged with deprotonation at high $\mathrm{pH}$ values (Sparks, 2005). Each ion has its own optimum $\mathrm{pH}$ range for adsorption, but in general, for cationic trace metals, the adsorption efficiency increases with $\mathrm{pH}$. When surface charge becomes neutral at a determined $\mathrm{pH}$, i.e, the total concentration of surface anionic sites is equal to the total concentration of surface cationic sites, this $\mathrm{pH}$ 
value is named the Point of Charge Zero (PCZ) (Sparks 2005). At pH values above the PCZ, the surface is overall negatively charged, and vice-versa.

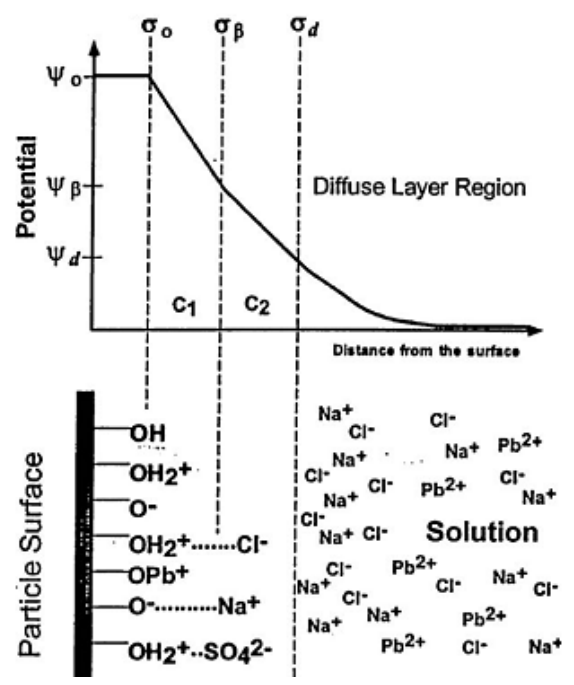

Fig.4. Schematic view of the electrical double layer at a mineral/aqueous solution interface showing possible inner-sphere $\left(\mathrm{Pb}^{2+}\right)$ and outer-sphere $(\mathrm{Cl}$, $\mathrm{Na}^{+}, \mathrm{SO}_{4}{ }^{2-}$ ) complexes and the drop off of the electrical potential away from the interface. Source: Hayes, 1987.

Both physical and chemical forces are involved in sorption processes. Physical forces include van der Waals forces (e.g. partitioning) and electrostatic coulombic interactions and tends to occur in outer-sphere complexation processes, i.e, during interactions between hydrated ions complexes and the solid surface. The presence of water molecules prevents the close approach of the metal ion to the surface functional groups of the solid surface, not allowing the formation of chemical bonds (Sposito, 1989). The outer-sphere processes is usually a rapid process that is reversible, and the adsorption occurs only on surfaces that are of opposite charge to the adsorbate. Chemical forces occurs in short-range interactions during inner-sphere complexation processes and involve ligand exchange mechanism, covalent bonding, and hydrogen bonding. Adsorption of ions via inner-sphere complexation can occur surface regardless of the original surface charge and is usually slower than outer-sphere complexation and is often not reversible (Stumm 1992; Sparks 2005; Heyden and Roychoudhury, 2015). A scheme of these different modes of adsorption is shown in Fig.5 using $\mathrm{Sr}$ as an example: i) the sorption of $\mathrm{Sr}\left(\mathrm{H}_{2} \mathrm{O}\right)_{8}{ }^{2+}$ aqueous complex onto the surface of Mn-oxyhidroxide via weak outer-sphere sorption in which the waters of hydration around $\operatorname{Sr}($ II) are retained and the 
interaction is electrostatic, ii) intermediate H-bonding interactions between the aqueous complex and the solid surface, and iii) strong inner-sphere bonding in which some of the waters of hydration are lost and the $\mathrm{Sr}^{+2}$ ion bonds directly to the Mn-oxyhidroxide surface, forming partly covalent bonds (Brown and Calas, 2011)..

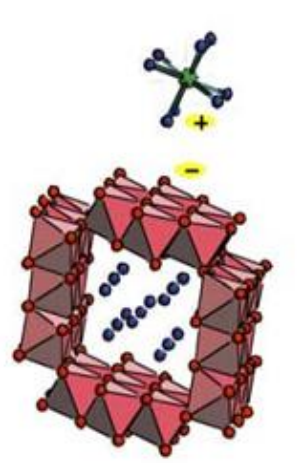

Outer-Sphere (electrostatic)

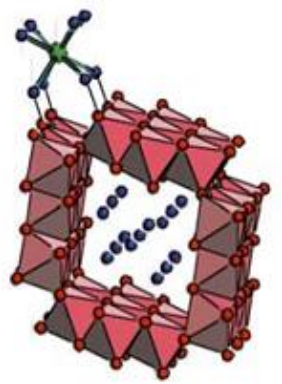

Intermediate (H-Bonding)
- STRONTIUM

- SURFACE HYDROXYL

- water molecule

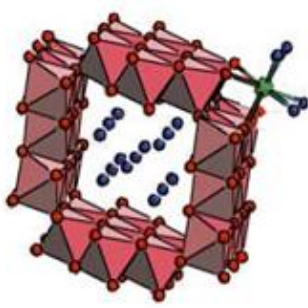

Inner-Sphere (covalent bonding)

Fig.5. Schematic illustration of different modes of $\operatorname{Sr}\left(\mathrm{H}_{2} \mathrm{O}\right)_{8}{ }^{2+}$ sorption onto Mn-oxidehydroxides surfaces. Source: Grolimund et al., 2000.

The metals weakly adsorbed (i.e. H-bonded or electrostatically bonded to mineral surfaces), can be released to solution by a simple change in the ionic strength or $\mathrm{pH}$ of the solution. In contrast, metal strongly adsorbed (i.e. forming direct covalent/ionic bonds with reactive sites on mineral surfaces) undergo desorption processes only with significant changes in the aqueous solution. Such dramatic lowering of $\mathrm{pH}$ is due to acid mine drainage (Brown and Calas, 2011). Therefore, determining the mode of binding of metal cations and oxyanions to mineral surfaces is an essential step in evaluating their mobility in aquatic systems. For this, synchrotron-based XAFS spectroscopy has been the main method for elucidating the dominant binding mode (i.e. inner- vs. outer-sphere, monodentate vs. bidentate, mononuclear vs. multinuclear) and average structure of metal ion and oxyanion sorption complexes at mineral/aqueous solution interfaces (Brown and Sturchio, 2002; Brown and Calas, 2011).

In the marine and fresh water mixing zone of estuaries, the partition between dissolved and particulate fractions is affected by coagulation, sedimentation and successive sorption processes triggered by a set of changes in physical and chemical conditions of the water column including salinity, temperature, dissolved oxygen and 
suspended material (Tercier-Waeber and Taillefert, 2007; Chester, 2000). All these processes induce either the addition or removal of dissolved components via particulate trapping on bottom sediments (Eby, 2004).

As fresh water enters a marine estuary, the $\mathrm{pH}$ increases from typical circumneutral to alkaline values above 8, leading to deprotonation of functional groups and increasing of sorption capacity of binding surfaces (Eby, 2004). In turn, the increasing of salinity (or ionic strength) leads to the release of metals adsorbed on colloids and particulate matter due to the competition between bound metal ions and major ions of marine water or due to the formation of soluble chloride complexes (Du Laing et al., 2009). The salinity also favors the coagulation and flocculation of suspended material by neutralizing the negative charges of the particles by electrolytes of seawater (Turner and Millward, 2000). The coagulation and flocculation and posterior settling on bottom sediment promote the water column scavenging by the adsorption of dissolved metals on the surface of particle sediments. (Mason, 2013). The region of high particulate load and settling is termed as Turbidity Maximum Zone (TMZ). As the sediment plumes obstruct light penetration in this zone, the highest productivity on the water column normally occur farther, in an area known as the Chlorophyll Maximum Zone-CMZ. The delimitations of these zones are variable, depending on estuarine type, circulation, and freshwater flow (Bianchi, 2007). These two regions account for most of the particulate settling and trace metal removal in the water mixing zone, which become the estuarine sediments; the main sink of metals exported from the continent toward the oceans (Bianchi, 2007; Mason, 2013).

\subsection{Biogeochemistry processes in the intertidal zones: tidal flats and mangroves}

The fluvial-estuarine sediments deposit within the intertidal zones at tidal flats and mangroves. These consist of the accumulation of large amounts of organic matter and nutrients brought by the rivers or produced by the primary activity linked to aquatic biomass of algae and phytoplankton (Jickells and Rae, 1997; Mason, 2013).

This organic matter can also be known as $\mathrm{CH}_{2} \mathrm{O}$ (formaldehyde), a very simple compound precursor of sugars and which is oxidized into $\mathrm{HCO}_{3}{ }^{-}$, the stable form of carbon in solution (Albarède, 2009). The labile fraction of the organic matter is associated with unstable compounds such as detritus of dead organisms, fecal pellets and low weight 
molecules such as carbohydrates, proteins, lipids, nucleic acids and pigments (Bianchi, 2007). Once in the environment, this fraction tends to decompose in relatively short times, from some hours to days. In turn, the most resistant (or inert) part of the organic pool tends to be less reactive in the environment. This fraction is generally associated to humic substances and/or molecules with long aliphatic chains of lipids derived from membrane material and the aromatic compounds derived from the phenol rings of lignin (Albarède, 2009).

Within sediments, the organic matter recycling (i.e, its remineralization) is directly influenced by the microbial activity. In order to obtain energy, these microorganisms promote the oxidation of the labile organic matter via enzymes using different metabolic pathways and oxidants (or electron acceptors: $\mathrm{O}_{2}, \mathrm{NO}_{3}{ }^{-}, \mathrm{MnO}_{2}$, $\mathrm{FeOOH}, \mathrm{SO}_{4}{ }^{2-}$ and $\mathrm{CO}_{2}$ ) following a sequence of reactions determined by energetic advantages and by the supplying of determined oxidant species (Chester 2000; Ebay, 2004) (Fig.6).

The oxygen penetration depth is a function of the relative supply of organic matter compared to the rate of diffusion of oxygen into the sediments. In the deep sea, organic matter supply is low and sediments are permeable, and so oxygen supply is sufficient to support aerobic degradation (Burdige, 2005). In estuarine sediments, the presence of mud flats with high content of organic matter results in the lowest oxygen penetration and in the dominance of anaerobic processes involving alternative oxidant species commonly abundant in marine sediments and marine water such as $\mathrm{MnO}_{2}, \mathrm{FeOOH}, \mathrm{SO}_{4}{ }^{2-}$ (Jickells and Rae, 1997).

Biogeochemical reactions and redox gradients driven by the decomposition of organic matter is given the term Diagenesis. Thus, the diagenetic processes can be defined as the combination of biological, chemical, and physical processes in the interstitialwater-sediment interface which lead to the formation of new and altered mineral phase, changes in the composition of waters themselves and the quantity and composition of the organic matter (Berner, 1980; Chester, 2000). In the case of intertidal zones, the diagenesis are also influenced by bioturbation processes and by the redox variations associated to often submersion and air exposition during tidal cycles (Ebay, 2004; Chester, 2000). 


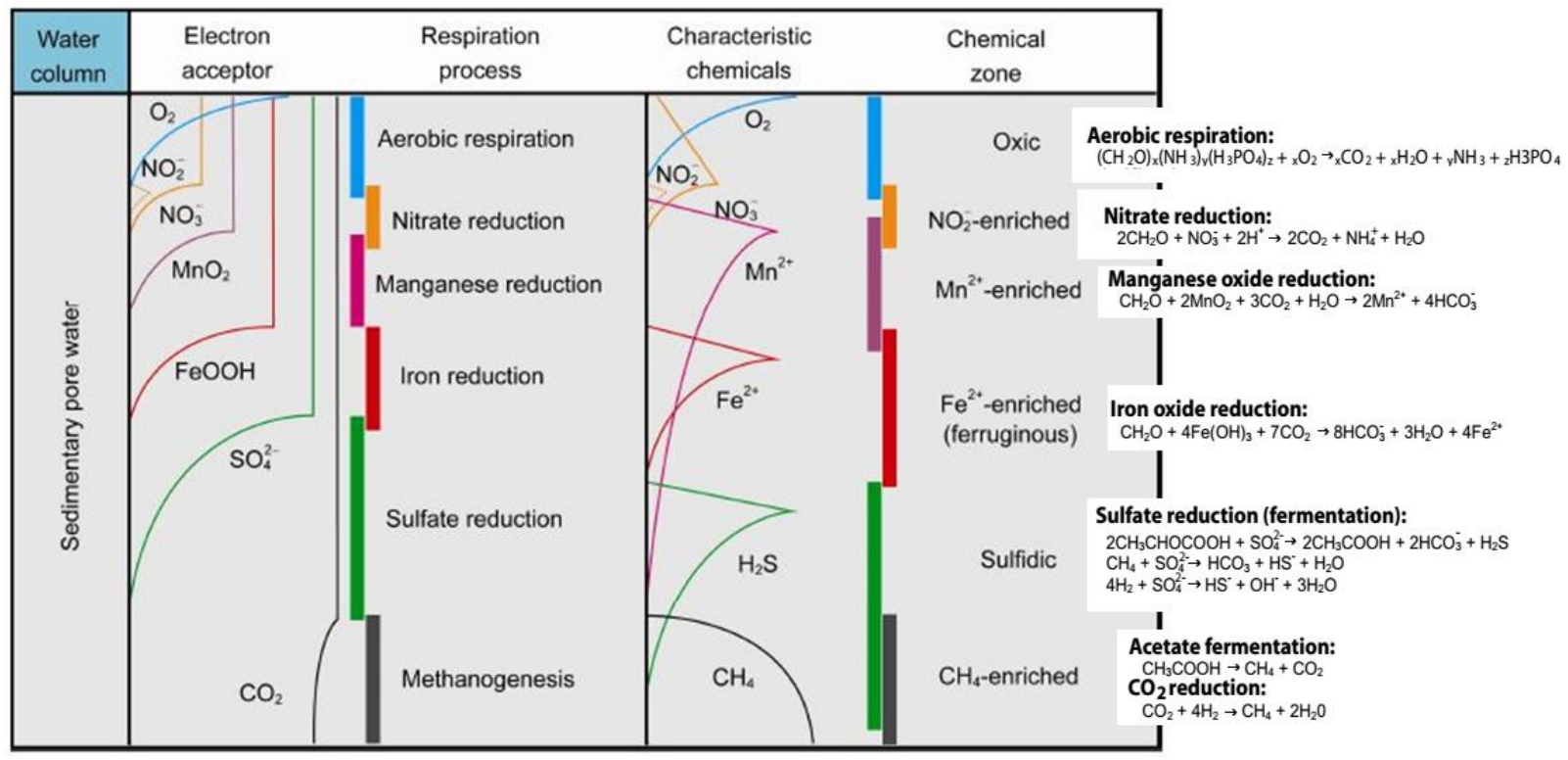

Fig.6. Bacterial decomposition of organic matter in marine/estuarine sediment through a sequence of terminal electron acceptors (e.g., $\mathrm{O}_{2}, \mathrm{NO}_{3}{ }^{-}, \mathrm{MnO}_{2}, \mathrm{FeOOH}, \mathrm{SO}_{4}{ }^{2-}$ and $\mathrm{CO}_{2}$ ) and changing redox. Source: Li et al.2015, modified from Canfield and Thamdrup, 2009.

In mud flat and mangrove sediments, the top oxic layers are well oxygenated by the bioturbation of burrowing animals, and so microorganisms use aerobic respiration mechanisms to oxidize the organic matter and converting it in carbon dioxide plus water (Albarède, 2009). As oxygen is exhausted, the organisms switch to a succession of anaerobic pathways using alternative terminal electron acceptors to oxidize organic matter (Fig.6). In these anaerobic conditions, nitrate $\left(\mathrm{NO}_{3}{ }^{-}\right)$is reduced to nitrogen (denitrification), which is lost to the overlying water through diffusion and advection of pore waters. The use of $\mathrm{O}_{2}$ and $\mathrm{NO}_{3}{ }^{-}$as oxidants causes a slight decrease in the $\mathrm{pH}$ of the pore waters, to values around 5 , an increase in the concentration of $\mathrm{CO}_{2}$ as a result of degradation of organic matter and increments in $\mathrm{Ca}^{+2}$ concentration and alkalinity, as a result the dissolution of $\mathrm{CaCO}_{3}$ ( $\mathrm{Li}$ et al., 2015).

After depletion of the nitrate supplying, ferric iron $\left(\mathrm{Fe}^{3+}\right)$ and $\mathrm{Mn}^{+4}$ present as hydroxides $\left(\mathrm{MnO}_{2}, \mathrm{FeOOH}\right)$ are progressively reduced and dissolved in the oxidation of the organic matter. While the most of the reduced $\mathrm{Mn}^{2+}$ returns to the column water, ferrous iron $\left(\mathrm{Fe}^{+2}\right)$ reacts with the sulfur liberated by the dissimilatory reduction of sulfate and precipitates as insoluble iron sulfides (amorphous-FeS, mackinawite-FeS, greigite$\mathrm{Fe}_{3} \mathrm{~S}_{4}$, pyrrhotite $\mathrm{FeS}_{1.1}$ ) and posteriorly as pyrite-FeS $\mathrm{S}_{2}$ (Huerta-Diaz and Morse, 1990; Morse and Luther, 1999; Machado et al.,2014). The latter constitutes a common 
authigenic mineral in sediments with high organic matter content. The anaerobic degradation of organic matter using $\mathrm{MnO}_{2}, \mathrm{FeOOH}, \mathrm{SO}_{4}{ }^{2-}$ as oxidants is accompanied by an increase in alkalinity with production of $\mathrm{HCO}^{3-}, \mathrm{HS}^{-}, \mathrm{HPO}_{4}{ }^{2-}, \mathrm{FeS}_{2}, \mathrm{NH}_{4}{ }^{+}$and precipitated of $\mathrm{CaCO}_{3}$ in the form of aragonite and calcite produced biologically. The $\mathrm{CO}_{2}$ produced in this decomposition is the precursor of anion $\mathrm{HCO}_{3}{ }^{-}$, which is primarily responsible for the alkalinity (Albarède, 2009).

The diagenesis have important implications for trace metal cycling. In low oxygen environments, the anaerobic metabolic processes can induce dissolution of Fe and $\mathrm{Mn}$ oxyhydroxides phases leading to the release of trace metals to interstitial water. This can make these metals available for transport, organism incorporation or sediment redistribution (Mason, 2013). In cases of environments with high degree of anoxia and sulfate supplying the trace meals can also interact with insoluble sulfides adsorbing it, entering the iron sulfides structure via isomorphic substitution, or forming its own minerals (Morse and Luther, 1999; Huerta-Diaz and Morse, 1990). This association of trace metals to insoluble sulfides decrease the biological availability and the potential of toxicity for the biota (Ankley et al., 1996, MERAG, 2007).

In mangroves sediments, the intense diageneses promote the partition of trace metal between the different sorbent phases (Fe-Mn oxyhidroxides, organic matter, clay minerals, sulphides, etc.) in stratified redox zones from oxic to anoxic layers (Fig.7). This partition is largely influenced by the controlling factors of redox conditions as the quantity and reactivity of organic matter, sediment grain size, bioturbation activity, rhizosphere processes, and periods of water logging during tidal cycles (Lewis, 2011; Marchand et al., 2011). In general, the characteristic high organic matter and sulfides in the anoxic zones of mangroves gives this system its large capacity to retain metals and act as sinks for these elements. The formation of sulfides is favored during high tide where sediments become waterlogged and remain under anoxic conditions (Andrade et al.2012; HuertaDiaz and Morse, 1990). Furthermore, the sulfidic phase can be oxidized when exposed to air during the low tide or by the $\mathrm{O}_{2}$ inputs driven by the exchanges between rhizosphere and atmosphere or diffused by bioturbation activity (Lewis, 2011; Bayen 2012; Machado et al.2014). The oxidation of sulphides result in the precipitation of Fe-oxyhydroxides and formation of Fe plaques around root surfaces and ultimately results in significant accumulation of trace metals in these zones (Lacerda et al., 1993;Chaudhuri et al., 2014). Thus, the redox variations in mangrove sediments can be understand as two contrasting 
effects taking place in the biogeochemical cycling of trace metals: first, the oxidation process of sulfides increases the mobility and availability of trace elements, then, the precipitation of $\mathrm{Fe}$-oxyhydroxides tends to decrease the mobility and biodisponibility to plant uptaking (Lacerda et al., 1993; Chaudhuri et al., 2014)

The formation of metal-sulfides, metal-organic matter complexes and adsorption on Fe-plaques on the roots of plants restricts their bioavailability for plant uptake. This results in a low metal allocation in leaves, which in turn reduces the metal export through leaf litter transport, as well as the metal availability to enter in food chains based on leaf consumption (Machado and Lacerda, 2004). Low metal concentrations in leaves have also been attributed to tolerance mechanism of mangroves to exclude metals or regulate their translocation to the shoot and leaves (McFarlane and Burchett, 2002). The metal uptake can be regulated at the root endodermis through modifying uptake from predominantly apoplastic to selective symplastic transport (McFarlane and Burchett, 2000). Overall, mangrove plants tend to operate as excluder species for non-essential metals and regulators of essential metals (MacFarlane et al., 2007). 


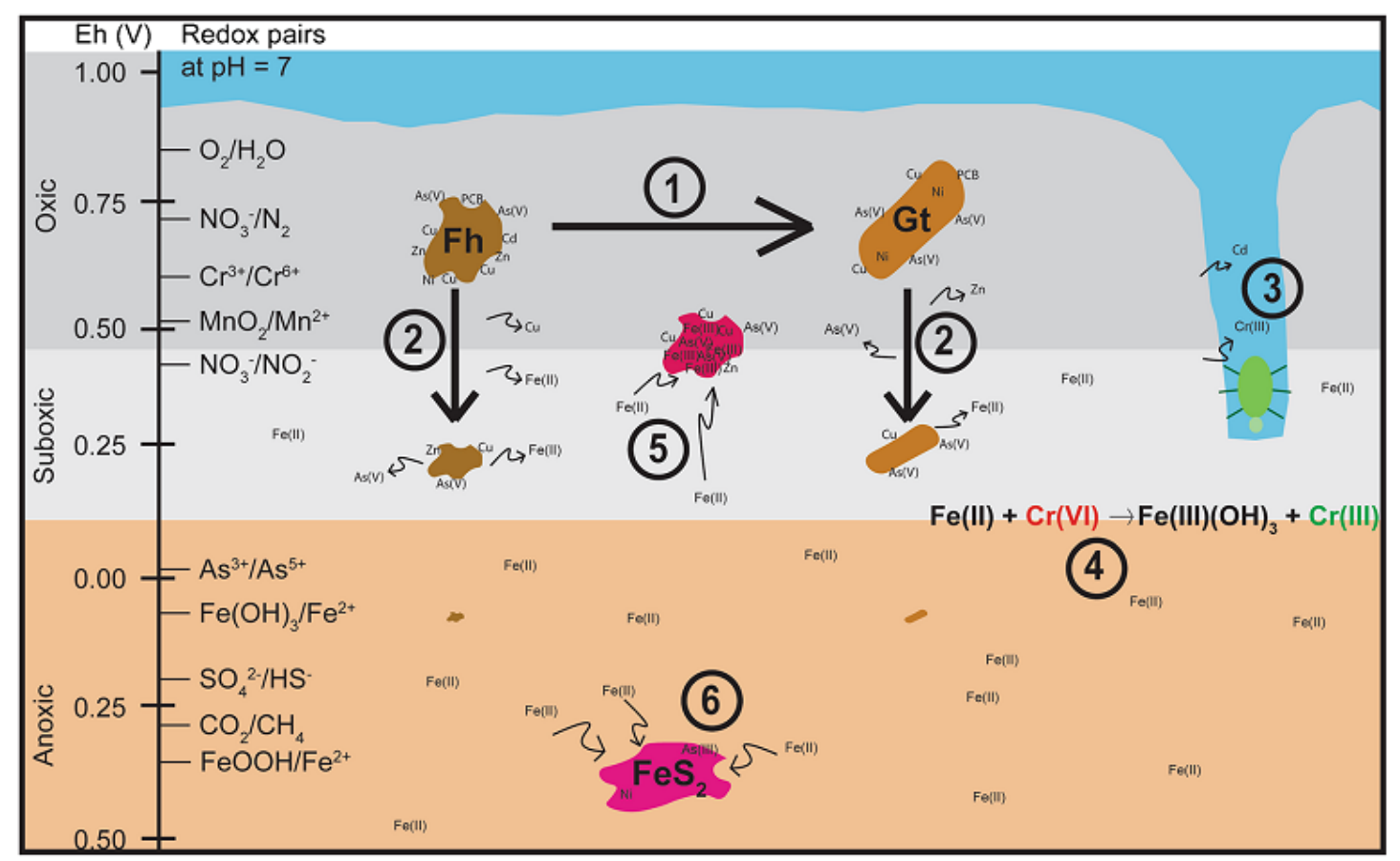

Fig.7. Interactions between Fe mineral phases and inorganic and organic contaminants and the transformations and variations that occur due to sediment biogeochemistry. (1) Ageing transformations from poorly crystalline phases (e.g. ferrihydrite, schwertmannite) to more crystalline phases (e.g. goethite, hematite) typically lead to an expulsion of adsorbed contaminants due to decreases in mineral surface area. However, divalent cations associated with the more crystalline phases typically become more recalcitrant. (2) Reductive dissolution of Fe oxide minerals leads to the release of adsorbed and co-precipitated contaminants, with a concomitant release of reduced Fe(II) into solution. (3) Disturbances to the sediment structure during diagenesis (e.g. bioturbation, dredging and sediment re-suspension) can lead to speciation changes (due to infiltrating $\mathrm{O}_{2}$ ) and can also lead to release of contaminants into the water column, thus posing a threat to aquatic organisms. (4) The released flux of Fe(II) can act as an electron donor during coupled redox transformation of contaminant phases. This is the premise on which the $\mathrm{Fe}(0)$ and $\mathrm{Fe}(\mathrm{II})$ amendment strategies are based. (5) The reduced Fe(II) flux can also reprecipitate at the redox boundary to form poorly crystalline phases (including mixed metal species such as FeAsO4-H2O) which can incorporate various trace metal contaminants. (6) Under highly anaerobic conditions, sulphur speciation has the strongest control on contaminant chemistry. Pyrite readily precipitates and can incorporate trace metals such as Co and Ni. Source: Heyden and Roychoudhury, 2015.

\subsection{Bivalve molluscs: ecological importance and applicability as biomonitors of metal contamination}

Chemical analysis of natural mediums such as water, soil and sediment is widely employed as the most direct approach to assess the metal(oid) contamination status 
and possible risks for the biota (Zhou et al.2008). However, these samples are limited to evaluate the bioavailability and toxicity of the contamination on the organisms and ecosystem. Alternatively, the sampling and analysis of biological samples (biomonitors) such as individual organism's tissues and fluids, can inform about the amounts of metals that have entered and remained in the organisms, indicating the portions of the total ambient metal load that present ecotoxicological relevance, as well as possible deleterious effects (Raibow, 1995; Market et al., 2003). Thus, biomonitors are useful to establishing either geographical and temporal variations in the bioavailabilities of metals and are advantageous to reduce the costs of environmental monitoring programmes (Raibow, 1995).

For aquatic metal contamination, biomonitor samples include plankton, insects, molluscs, fish, plants, and birds. While macrophytic alga responds essentially to dissolved metal sources only, bivalve mollusc responds to metal sources in dissolved and suspended phases, and a deposit feeder responds to metal available in sediment (Zhou et al., 2008; Raibow, 1995).

Despite this variety of options and their specificities, bivalve molluscs have been the class of animals most employed in environment studies concerning metal contamination due their several suited tributes as biomonitor and ecological relevance (Oehlmann and Schulte-Oehlmann, 2003). The bivalves represent the second most abundant between the six classes of the phyla Mollusca, which is one of the most diverse phyla in the animal kingdom (more than 130.000 known species; Gosling, 2003). Molluscs bivalves are soft-bodied animals laterally compressed by two protective shells. Abundant and ubiquitous in nature, they occur in almost all coastal habitats found on Earth on a large variety of substrates including rocky shores, coral reefs, mud flats, and sandy beaches and have a vital ecological role in different aquatic and terrestrial ecosystems. Molluscs are responsible for litter decomposition and contribute large amounts of biomass to the different trophic levels in ecosystems (from primary consumers to top predators), and are common preys of other animals like echinoderms, fish, birds and mammals (Castro and Huber, 2010). Bivalve molluscs are also economically important. They constitute an important part of the diet of many human populations, mainly in coastal zones, presenting high nutritious value, with high protein content, many amino acids, and relatively low fat content (actionbioscience, 2016). Today, the knowledge of mollusc reproductive cycles has led to the development of hatcheries and new culture techniques. In 1999, over $95 \%$ of all oysters were consumed 
from aquaculture origin whereas the corresponding figures for mussels, scallops and clams were $86 \%, 63 \%$ and $77 \%$, respectively (FAO, 2001). Since the molluscs can contain toxins (produced by theyself or accumulated from environment), or act as vectors for a number of human-relevant parasites and diseases, their consumption requires special attention by public-health organisations (Goslim, 2003). Bivalves are also important for the economy in the production of pearls industry (Fassler, 1995).

Several attributes make molluscs good organisms for environmental monitoring: firstly, their sedentary nature does not require consideration of complex migratory factors in the interpretation of the bioaccumulation data (Gupta and Singh, 2011; Zhou et al., 2008). Secondly, they are strong bioaccumulators of chemicals, possessing high uptake and low efflux rates for metals, capable of filtrating large water volumes and incorporating metals in their tissues and shells in higher than the surrounding environment (Gupta and Singh, 2011; Wang et al., 1996). Thus, chemicals present at undetectable levels in water can be identified in bivalves due to their high bioaccumulation ability. Bivalves present other desirable characteristics for biomonitors. They are abundant and widely found, geographical, show tolerance to environmental alterations and various environmental contaminants, have wide and stable populations, reasonably long-lived, reasonable sized, and withstand rough environments during laboratory and infield studies (Oehlmann and Schulte-Oehlmann, 2003).

Despite bivalves adequately fulfilling the requirements as biomonitors, it is import to emphasizes that it is impossible to determine contamination levels in an aquatic ecosystem directly or in an absolute way, using only metal bioaccumulation data in bivalves because they are influenced by a number of biotic and abiotic factors (Zuykov et al., 2013). Bioaccumulation results from a dynamic equilibrium between exposure from the outside environment and uptake, excretion, storage, and degradation within an organism. These in turn, are influenced by biotic and abiotic factors (e.g., species variability, gender, age, body size, nutrition, reproductive status, temperature, salinity, pH, light, mode of exposure, etc.) (Raiwbow, 1995; Zhou et al., 2008; Zuykov et al., 2013). Furthermore, due to a depuration effect, the residence time of the pollutant may be shorter than the time interval separating two sampling periods (Freitas et al., 2012). Understanding of the dynamic process of bioaccumulation is, therefore, crucial for accurately interpret the magnitude of environmental impacts. 


\subsection{Bivalve mollusc morphology and feeding behavior}

Bivalves are characterized by two oval or elongate valves, which enclose the visceral mass. They are entirely aquatic and rather stationary organisms, generally possessing a muscular foot which they use to attach themselves to the substrate and/or burrow down into sediments (Castro and Huber, 2010).

The first part of a bivalve shell to develop is the umbo which is seen as a large bump towards the anterior end of the dorsal side of the shell. An internal elastic ligament automatically opens the valves, but by contracting one of two of its adductor muscles it is able to hold the shell shut. The inner surface of the shell is lined by the mantle, so that the whole body lies in the mantle cavity, a large space between the two halves of the mantle (Castro and Huber, 2010).

As mentioned before, bivalves are filtering-feeding, i.e, obtain their aliment (bacteria, phytoplankton, microzooplankton, detritus, amino acids and sugar) through water passing over a specialized filtering structure. For this, two siphons are used: one, the inhalant siphon, which carries water to the internal cavity, while the exhalant siphon takes water away from the internal cavity. In certain cases these siphons can be fused, but the water in the two tubes still remains separate. Once inside the water runs by folded gills, which are used not only to obtain oxygen, but also to filter and sort via cilia small food particles from the water. The gills also can control the rate at which suspended material is removed from the surrounding water by ciliary beat or muscular expansion of the ostia. Most bivalves retain particles as small as $0.4-0.6 \mu \mathrm{m}$ with $86 \%$ of its efficiency for larger particle capture (Goslim, 2003). The retained food particles are incorporated to a mucus and then carried by cilia along food grooves on the edges of the gills to the mouth region, where the particles are sorted on the ciliated labial palps before to pass the mouth, esophagus and reach the stomach (Goslim, 2003).

The digestive gland opens into the stomach by several ducts, which liberate digestive enzymes to mix with ingested particles. The ciliary system of the stomach beast coordinately causing the rotation of the crystalline style, an elongated rod of solidified mucus, which promotes the constant mixing of particles and digestive enzymes and propels food particles into a sorting region at the rear of the stomach, distributing smaller particles into the digestive glands, and heavier particles into the intestine. Some of digestive glandes also include cells that phagocytose food particles, and digest them 
intracellularly. Waste or segregated material not digested are channeled into the intestine along a deep rejection groove and eliminated by the anus as pellets (Goslim, 2003).

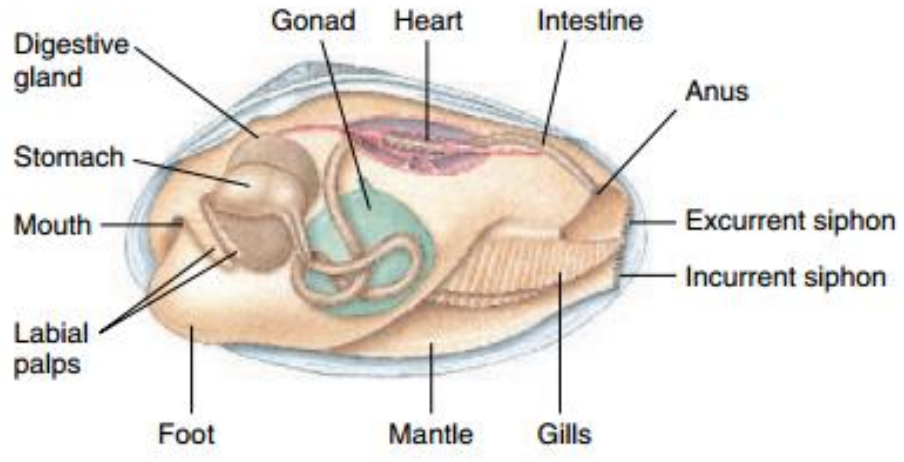

(a)

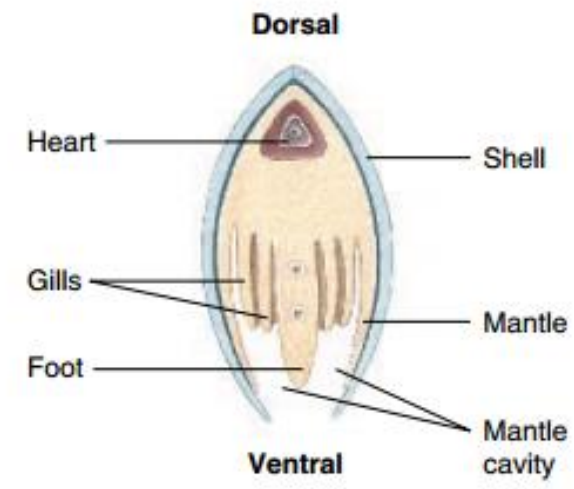

(c)

Fig.8. A laterally compressed body is the most distinctive feature of bivalves, illustrated here by a clam. The gills, which hang on both sides of the body $(a, c)$, sort out food particles and transport them to the mouth with the help of cilia and mucus. The palps then push the food into the mouth. Food is then digested in the stomach with the help of the crystalline style (b). The path of the particles from the incurrent siphon to the mouth is indicated by arrows (d). Source: (Castro and Huber, 2010).

\subsection{Metal bioaccumulation mechanisms and their implications for environmental} risk assessing

Bivalves are able to uptake metals in different forms by different routes (free metal ions, metal complexes, and particle-bound metals), as schematized in Fig.9. The most important sites for absorption of dissolved metals are the gills. Metals bound to particulate phases can be incorporated post desorption or solubilization by enzymes and non- 
enzymatic ligands during digestion processes in the gastro-intestinal tract (Griscom and Fishcer, 2004).

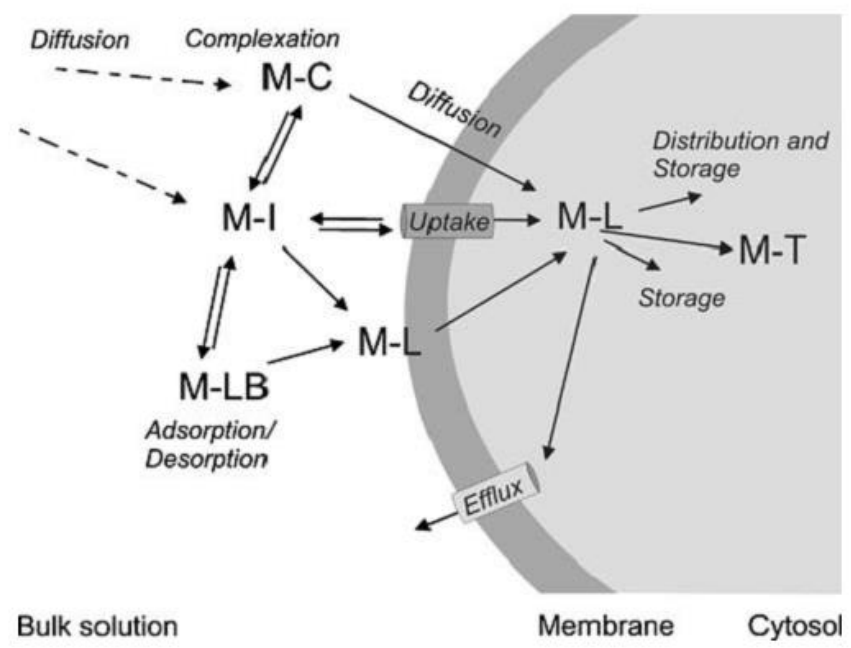

Fig.9. Conceptual model of the main processes and sources for uptake of trace metals at a biological membrane. (M-C metal complex, MImetal ion, M-LB labile particle-bound metal, M-T metal at target site, M-L metal bound to a biological ligand). Source: Ahlf et al., 2009.

Not all ingested metal is assimilated during the digestion processes. The assimilation efficiency (AE), defined as the fraction of metal incorporated into animal tissue after initial absorption across the gut lining following digestion, is conditioned by several factors. These include the nature and physiology of the organism (ingestion rate, gut passage time, and relative significance of extracellular and intracellular digestion), characteristics of the ingested particles (size, organic content and composition, degree of metal contamination, abundance of microalgae and adherent bacteria), and the nature and reactivity of the metal (distribution coefficient, redox behavior, ability to penetrate cytosolic material and gut lining) (Wang, 2002). In general, metals which preferentially sorb to fine, organic-rich particles, or linked to the cytosolic material, desorb at $\mathrm{pH} 5$ to 6 (the conditions in the bivalve gut), and occur in organometallic forms are assimilated with greatest efficiency (Decho and Luoma, 1994; Lee and Luoma, 1998; Griscom et al., 2002).

The assimilation of metals to the bivalve tissue occurs across the plasma membrane of epithelial cells of the gills or gut, which most likely occurs via facilitated diffusion or by energy dependent processes such (i) transport by a membrane-protein of relatively wide specificity; (ii) transport by specific proteins of the plasma membrane 
through which metal ions pass selectively; or (iii) endocytosis (Langston and Bebianno, 1998).

After crossing the plasma membrane, the incoming metal binds immediately to ligands and distributes between sites of storage, efflux, or toxic action (Ahlf et al., 2009). In the case of an essential metal, it is available to bind to sites where it can play an essential role (e.g. zinc in the enzyme carbonic anhydrase or copper in haemocyanin) or, if present in excess (caused by entry at too high a rate), to sites where it may cause toxic effects. To avoid reaching toxication, the bivalve cells can activate detoxification mechanisms, which involves the binding of metals to proteins such as metallothioneins or to insoluble metaliferous granules, in order to make the metal unavailable to play any activity in metabolic processes (Rainbow, 2002; Raibow, 2007). In this way, the accumulated trace metal in the organism can be classified into two components: (i) metabolically available metal and (ii) stored detoxified metal. Toxicity results when the rate of metal uptake from all sources (via particulate and dissolved) exceeds the combined rates of detoxification and excretion of the metal concerned (Rainbow, 2002; Ahlf et al., 2009).

The link between bioavailability, metal bioaccumulation mechanisms and toxicity effects in aquatic invertebrates are currently ongoing research themes (Luoma and Rainbow, 2005; Bourgeault et al., 2011; Rainbow and Luoma, 2011). Of major interest is the understanding of the factors controlling metal bioavailability and the routes of metal assimilation (via dissolved, food or particulate) for better regulation of water and sediment quality criteria, comprehension of metal trophic transfer and biogeochemical cycling in coastal systems (Wang and Fishier, 1999). In this sense, different approaches have been used to predict the bioavailability and toxicity of metals in water and sediment. The first, named Biotic Ligand Model (BLM), have been developed to explain and predict the effects of water chemistry on the toxicity of metals (MERAG, 2007; Ahlf et al., 2009). This model combines the geochemical complexities and biological ligands that affect metal exposure, considering the influences of speciation (e.g., free metal ion, dissolved organic complexation) and cationic competition (e.g., $\mathrm{K}^{+}, \mathrm{Na}^{+}, \mathrm{Ca}^{2+}$ and $\mathrm{Mg}^{2+}$ ) on metal toxicity to organisms (Di Toro et al., 2001; Santore et al., 2001; Deleebeeck et al., 2007). The biological surface (e.g., gill) is seen as a ligand competing with other organic molecules in the water phase. This kind of equilibrium partitioning method is a tool, which is increasingly used for regulatory purposes (US EPA 2003; MERAG, 2007). Although the model has been validated in a couple of studies, some inherent limitations 
have been documented for organisms that can uptake metals from algae, bacteria and colloidal matter, beyond of the dissolved phase (Hassler et al. 2004).

Other approach for risk assessment of metals, applicable for anoxic sediments, is the concept of sulfide bound metals described by the ratio of simultaneously extracted metals (SEM) and acid volatile sulfide concept (AVS). This model assumes that the potential bioavailability of a metal could be predicted by comparing the relative molar concentrations of the SEM and AVS, both obtained in extraction with $1 \mathrm{M} \mathrm{HCl}$. If sufficient sulfide exists to bind all SEM as insoluble compounds, no release of metal to pore water occurs and metal toxicity will not expected. Unlike, if SEM exceed the AVS concentration, a potential toxicity can be expected. The SEM-AVS concept has been shown to be predictive for the lack of toxicity for metals having a high affinity for AVS, e.g., $\mathrm{Cd}, \mathrm{Cu}, \mathrm{Pb}, \mathrm{Ag}$, and $\mathrm{Zn}$. As the BLM model, the SEM-AVS approach assumes also that the free ion concentration is the greatest exposure pathway (MERAG, 2007; Ahlf et al.2009).

Approaches have also been developed to predict and understand the metal concentrations in aquatic invertebrates (Wang and Fisher, 1999; Wang, 2002; Griscom and Fisher, 2004). One is by the use of a simple kinetic model which considers the metal uptake by dissolved and dietary phases as first-order physiological process (Luoma and Rainbow, 2005). This model represents the accumulation of metals in an animal as a balance of the rates of metal uptake into and loss out of the organism (Fig.10), where uptake from each source is additive (food + water). Loss of metals from an animal proceeds by excretion, diffusion, and fecal depuration. Furthermore, the relative importance of each uptake pathway can then be quantitatively assessed by comparing influx rates into the animals from each source. However, the model requires metal uptake and loss rates, typically quantified in laboratory experiments, and measurements of metal concentrations in food (including sediments) and water from a specific study area (Wang and Fisher, 1999; Griscom and Fisher, 2004; Luoma and Rainbow, 2005). The rate determinations, combined with field concentrations of metal in food and water from the study area are used to predict metal concentrations in animals from that particular area. Because the variability of each physiological parameter can be measured over a wide range of environmental conditions, the kinetic model is more flexible than empirical studies for delineating metal exposure pathways under different field conditions (Wang and Fisher, 1999; Griscom and Fisher, 2004; Luoma and Rainbow, 2005). 


\section{Conceptual View of Model \\ (Simple one-box system)}

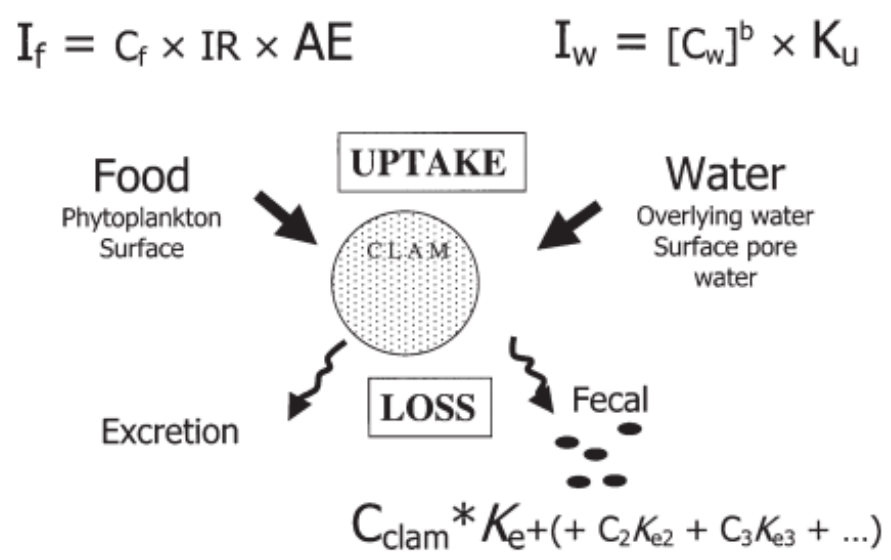

Fig.10. Conceptual view of the biokinetic model and the equations used to understand the concentrations of trace metals accumulated by aquatic invertebrates. If : influx rate of metal from food ( $\mu \mathrm{g} \mathrm{metal} \mathrm{g}^{-1}$ animal dry wt $\left.\mathrm{d}^{-1}\right)$; Cf : metal concentration in the food $\left(\mu \mathrm{g}\right.$ metal $\mathrm{g}^{-1}$ food dry $\left.\mathrm{wt}\right)$; IR: ingestion rate $(\mathrm{g}$ food dry wt $\mathrm{g}^{-1}$ clam dry wt); AE: assimilation efficiency of ingested metal; Iw: the influx rate from water ( $\mu \mathrm{g}$ metal $\mathrm{g}^{-1}$ animal dry wt $\left.\mathrm{d}^{-1}\right)$; ku: uptake rate constant from dissolved phase $\left(\mathrm{g} \mathrm{g}^{-1} \mathrm{~d}^{-1}\right)$; Cw: metal concentration in dissolved phase $\left(\mu \mathrm{gl}^{-1}\right)$; b: power of the relationship, typically $=1 \pm 0.1$, unless metal uptake is biologically regulated; ke : the rate constant of loss (from the slowest compartment; $\mathrm{d}^{-1}$ ); C2and C3,ke and ke:metal concentrations in compartments $\mathrm{Cn}$ in the clam with loss rates. Source: Griscom and Fisher, 2004. 


\section{References}

ActionBioscience (2016)-promoting bioscience literacy. Actionbioscience.org. Available at: http://www.actionbioscience.org/ [Accessed July 21, 2016].

Adriano D. and Adriano D. (2001) Trace elements in terrestrial environments. Springer, New York.

Agardy, T. and Alder, J.(2003) Coastal Systems (chapter 19) In: Ecosystems and human well-being(eds Alcamo J. and Bennett E.). Island Press, Washington, DC.

Ahlf W., Drost W. and Heise S. (2009) Incorporation of metal bioavailability into regulatory frameworksmetal exposure in water and sediment. J Soils Sediments 9, 411-419.

Albarède F. (2009) Geochemistry an introduction. Cambridge University Press, Cambridge.

Alcamo J. and Bennett E. (2003) Ecosystems and human well-being., Island Press, Washington, DC.

Anderson D., Lively J. and Vaccaro R. (1984) Copper complexation during spring phytoplankton blooms in coastal waters. Journal of Marine Research 42, 677-695.

Andrade R., Sanders C., Boaventura G. and Patchineelam S. (2012) Pyritization of trace metals in mangrove sediments. Environ Earth Sci 67, 1757-1762.

Ankley G.T. (1996) Evaluation of metal/acid-volatile sulfide relationships in the prediction of metal bioaccumulation by benthic macroinvertebrates. Environmental Toxicology and Chemistry, 15 (12), 21382146.

Aufdenkampe A., Hedges, J.I., and Richey J.E. (2001) Sorptive fractionation of dissolved organic nitrogen and amino acids onto fine sediments within the Amazon Basin. Limnol. Oceanogr. 46, 1921-1935.

Bayen S. (2012) Occurrence, bioavailability and toxic effects of trace metals and organic contaminants in mangrove ecosystems: A review. Environment International 48, 84-101.

Beck, M.W., K.L. Heck, K.W. Able, D.L. Childers, D.B. Eggleston, et al. 2001: The identification, conservation, and management of estuarine and marine nurseries for fish and invertebrates. Bioscience, 51(8), 633-641.

Berner, R.A. (1980) Early Diagenesis: a Theoretical Approach. Princeton, NJ: Princeton University Press.

Bianchi T. (2007) Biogeochemistry of estuaries.Oxford University Press, Oxford.

Bourgeault A., Gourlay-Francé C., Priadi C., Ayrault S. and Tusseau-Vuillemin M. (2011) Bioavailability of particulate metal to zebra mussels: Biodynamic modelling shows that assimilation efficiencies are site-specific. Environmental Pollution 159, 3381-3389.

Brown G. and Calas G. (2011) Environmental mineralogy - Understanding element behavior in ecosystems. Comptes Rendus Geoscience 343, 90-112.

Brown Jr. G.E., Sturchio, N.C., 2002. An overview of synchrotron radiation applications to low temperature geochemistry and environmental science. Rev. Mineral. Geochem. 49, 1-115

Burdige, D.J. (2005) Burial of terrestrial organic matter in marine sediments: A re-assessment. Global Biogeochemical Cycles, 19(4), Article \# GB002368

Canfield D., Thamdrup B. and Hansen J. (1993) The anaerobic degradation of organic matter in Danish coastal sediments: Iron reduction, manganese reduction, and sulfate reduction. Geochimica et Cosmochimica Acta 57, 3867-3883.

Castro P. and Huber M. (2010) Marine biology. McGraw-Hill, New York.

Chaudhuri P., Nath B. and Birch G. (2014) Accumulation of trace metals in grey mangrove Avicennia marina fine nutritive roots: The role of rhizosphere processes. Marine Pollution Bulletin 79, 284-292.

Chester R. (2000) Marine Geochemistry.Blackwell science, Malden.

Decho A. and Luoma S. (1994) Humic and fulvic acids: sink or source in the availability of metals to the marine bivalves Macoma balthica and Potamocorbula amurensis?. Marine Ecology Progress Series $108,133-145$.

Deleebeeck NME, De Schamphelaere KAC, Janssen CR (2008) A novel method predicting nickel bioavailability and toxicity to Daphnia magnain artificial and natural waters. Environ Toxicol Chem 27:2097-2108 
Di Toro DM, Allen HE, Bergman HL, Meyer JS, Paquin PR (2001) Biotic ligand model of the acute toxicity of metals. 1. Technical basis. Environ Toxicol Chem 20:2383-2396.

Du Laing G., Rinklebe J., Vandecasteele B., Meers E. and Tack F. (2009) Trace metal behaviour in estuarine and riverine floodplain soils and sediments: A review. Science of The Total Environment 407, 3972-3985.

Eby G. (2004) Principles of environmental geochemistry., Thomson-Brooks/Cole, Australia.

FAO Food and Agricultural Organisation (2001) Aquaculture production 1970-1999. Fish stat Plus (v. 2.30. FAO, Rome.

FAO Food and Agriculture Organization of the United Nations (2007) The world's mangroves 1980-2005. Forestry Paper 153. FAO, Rome.

Fassler C.R. (1995) Farming jewels: new developments in pearl farming.World Aquaculture, 26, 5-10.

Freitas R., Ramos Pinto L., Sampaio M., Costa A., Silva M., Rodrigues A., Quintino V. and Figueira E. (2012) Effects of depuration on the element concentration in bivalves: Comparison between sympatric Ruditapes decussatus and Ruditapes philippinarum. Estuarine, Coastal and Shelf Science 110, 43-53.

Giri C., Ochieng E., Tieszen L., Zhu Z., Singh A., Loveland T., Masek J. and Duke N. (2010) Status and distribution of mangrove forests of the world using earth observation satellite data. Global Ecology and Biogeography 20, 154-159.

Gosling E. (2003) Bivalve molluscs. Fishing News Books, Oxford.

Griscom S., Fisher N. and Luoma S. (2002) Kinetic modeling of Ag, Cd and Co bioaccumulation in the clam Macoma balthica: quantifying dietary and dissolved sources. Marine Ecology Progress Series 240, 127-141.

Griscom S. and Fisher N. (2004) Bioavailability of sediment-bound metals to marine bivalve molluscs: An overview. Estuaries 27, 826-838.

Grolimund D., Warner J.A., Carrier X., Brown Jr. G.E., (2000). Chemical behavior of strontium at the solid-liquid interface of hydrous manganese oxide: A molecular-level studyusing EXAFS (abstr.), Goldschmidt 2000. J. Conf. Abstr. 5, 461.

Gupta S. K., and Singh J. (2011). Evaluation of mollusc as sensitive indicatior of heavy metal pollution in aquatic system: a review. The IIOAB Journal,2(1), 49-57.

Hayes KF, Leckie JO. Modelling ionic strength effects on cationsorption at hydrous oxide/solution interfaces. J Colloid InterfaceSci. 1987;115:564-72.

Heyden B., von der and Roychoudhury A. (2015) Application, Chemical Interaction and Fate of Iron Minerals in Polluted Sediment and Soils. Curr Pollution Rep 1, 265-279.).

Huerta-Diaz M. and Morse J. (1990) A quantitative method for determination of trace metal concentrations in sedimentary pyrite. Marine Chemistry 29, 119-144.

Jickells T. and Rae J. (1997) Biogeochemistry of intertidal sediments., Cambridge University Press, Cambridge, U.K.

Lacerda L., Carvalho C., Tanizaki K., Ovalle A. and Rezende C. (1993) The Biogeochemistry and Trace Metals Distribution of Mangrove Rhizospheres. Biotropica 25, 252.

Langston W. and Bebianno M. (1998) Metal metabolism in aquatic environments., Chapman \& Hall, London.

Langston, W.J., Bebianno, M.J., Burt, G.R., (1998). Metal handling strategies in molluscs. In: Langston, W.J., Bebianno, M. (Eds.), Metal Metabolism in Aquatic Environments. Chapman and Hall, London, pp. 219-283.

Lee B. and Luoma S. (1998) Influence of microalgal biomass on absorption efficiency of Cd, Cr, and $\mathrm{Zn}$ by two bivalves from San Francisco Bay. Limnol. Oceangr. 43, 1455-1466.

Leonard, L.A., and Luther, M.E. (1995) Flow hydrodynamics in tidal marsh canopies.Limnol. Oceanogr. 40, 1474-1484.

Lewis M., Pryor R. and Wilking L. (2011) Fate and effects of anthropogenic chemicals in mangrove ecosystems: A review. Environmental Pollution 159, 2328-2346.

Li C., Cheng M., Algeo T. and Xie S. (2015) A theoretical prediction of chemical zonation in early oceans 
(>520 Ma). Science China Earth Sciences 58, 1901-1909.

Luoma SN, Rainbow PS (2005) Why is metal bioaccumulation so variable? Biodynamics as a unifying concept. Environ Sci Technol 39:1921-1931

MacFarlane G.R., Burchett M.D., (2000). Cellular distribution of copper, lead and zinc in the grey mangrove,Avicennia marina(Forsk.) Vierh. Aquatic Botany 68, 45e59.

MacFarlane G.R., Burchett M.D., (2002). Toxicity, growth and accumulation relationships of copper, lead and zinc in the grey mangrove Avicennia marina (Forsk.) Vierh. Marine Environmental Research 54, $65 \mathrm{e} 84$.

Machado W., Lacerda, L. (2004) Overview of the Biogeochemical Controls and Concerns with Trace Metal Accumulation in Mangrove Sediments In: Environmental geochemistry in tropical and subtropical environments (ed. Lacerda L.). Springer, Berlin.

MacFarlane, G.R., Koller, C.E., Blomberg, S.P., 2007. Accumulation and partitioning of heavy metals in mangroves: a synthesis offield studies. Chemosphere 69, 1454e1464.

Manceau A, Charlet L. (1994) The mechanism of selenite adsorption on goethite and hydrous ferric oxide. J Colloid Interface Sci.;168:87-93.

Marchand C., Allenbach M. and Lallier-Vergès E. (2011) Relationships between heavy metals distribution and organic matter cycling in mangrove sediments (Conception Bay, New Caledonia). Geoderma $160,444-456$.

Markert B., Breure A. and Zechmeister H. (2003) Bioindicators \& biomonitors., Elsevier, Amsterdam.

Martin, J.M., and Wollast, R., eds.), pp. 165-180, John Wiley, New York.

Mason A.Z., Jenkins, K.D., 1995. Metal detoxification in aquatic organisms. In: Tessier, A., Turner, D.R. (Eds.), Metal Speciation and Bioavailability in Aquatic Systems. John Wiley \& Sons, Chichester, UK, pp. 479-608.

Mason R.(2013) Trace metals in aquatic systems. Willey-Blackwell, Oxford.

Mayer L.M. (1994a) Surface area control of organic carbon accumulation on continentalshelf sediments. Geochim. Cosmochim. Acta 58, 1271-1284.

Mayer, L.M. (1994b) Relationships between mineral surfaces and organic carbonconcentrations in soils and sediments. Chem. Geol. 114, 347-363.

MERAG (2007) Metals Environmental Risk Assessment Guidance. The International Council on Mining and Metals (ICMM).

Millero F. (2001) Speciation of metals in natural waters. Geochem. Trans. 2, 56.

Millward G. (1995) Processes affecting trace element speciation in estuaries. A review. The Analyst 120, 609.

Millward, G.E., and Turner, A. (1995) Trace metals in estuaries.InTrace Elements in Natural Waters (Salbu, B., and Steinnes, E., eds.), pp. 223-245, CRC Press, BocaRaton, FL.

Morel, F.M.M., Dzombak, D.A., and Price, N.M. (1991) Heterogeneous reactions incoastal waters.InOcean Margin Processes in Global Change (Mantoura. R.F.C.

Morse J. and Luther G. (1999) Chemical influences on trace metal-sulfide interactions in anoxic sediments. Geochimica et Cosmochimica Acta 63, 3373-3378.

Newman M.C., and Jagoe C.H. 1994. Ligands and the bioavailability of metals in aquatic environments. In Bioavailability: physical, chemical, and biological interactions. Edited by J.L. Hamelink, P.F. Landrum, H.L. Bergmann, and W.H. Benson. Lewis Publishers, Boca Raton, Fla. pp. 39-61.

Oades J.M. (1989) An introduction to organic matter in mineral soils In: Mineral in Soil Environments (eds.Dixon, J.B., and Weed, S.B.), pp. 89-159, Soil Science Society of America, Madison, Willblack.

Oehlmann and Schulte-Oehlmann, (2003) Molluscs as bioindicators In: Bioindicators \& biomonitors (eds. Markert B., Breure A. and Zechmeister H.). Elsevier, Amsterdam.

Paquin P.R., Gorsuch J.W., Apte S., Batley G.E., Bowles K.C., Campbell P.G.C., Delos C.G, Di Toro D.M., Dwyer R.L., Galvez F., Gensemer R.W.,Goss G.G., Hogstrand C., Janssen C.R., McGeer J.C., Naddy R.B., Playle R.C., Santore R.C., Schneider U., Stubblefield W.A., Wood C.M. and Wu, K.B. (2002) The biotic ligand model: a historical overview.Comp. Biochem. Physiol. Part C 133, 3-35. 
Parametrix (1995) Persistence, Bioaccumulation and Toxicity of Metals and Metal Compounds.

Perillo G.M.E. (ed.) (1995) Definitions and geomorphic classifications of estuaries. In Geomorphology and Sedimentology of Estuaries. Developments in Sedimentology 53, pp. 17-47, Elsevier Science, New York

Post J.E. (1999) Manganese oxide minerals: crystal structures and economic and environmental significance. Proc. Natl.Acad.Sci.USA, 96, 347-3454.

Rainbow P. (1995) Biomonitoring of heavy metal availability in the marine environment. Marine Pollution Bulletin 31, 183-192.

Rainbow P. (2002) Trace metal concentrations in aquatic invertebrates: why and so what?. Environmental Pollution 120, 497-507.

Rainbow P. (2007) Trace metal bioaccumulation: Models, metabolic availability and toxicity. Environment International 33, 576-582.

Rainbow PS. (1998) Phylogeny of trace metal accumulation in crustaceans. In: Metal metabolism in aquatic environments (Eds. Langston WJ, Bebianno M). Chapman and Hall, London.

Rainbow P. and Luoma S. (2011) Metal toxicity, uptake and bioaccumulation in aquatic invertebratesModelling zinc in crustaceans. Aquatic Toxicology 105, 455-465.

Santore C, Di Toro DM, Paquin PR, Allen HE, Meyer JS (2001) Biotic ligand model of the acute toxicity of metals. 2. Application to acute copper toxicity in freshwater fish and Daphnia. Environ Toxicol Chem 20:2397-2402

Sparks D. (2005) Toxic Metals in the Environment: The Role of Surfaces. Elements 1, 193-197.

Sposito G (1989) The Chemistry of Soils. Oxford University Press, New York

Stumm W (1992) Chemistry of the Solid Water Interface. Wiley, New York

Stumm W., Morgan J.J. Aquatic chemistry: chemical equilibria and rates in natural waters (Vol. 126). John Wiley \& Sons. 2012.

Tercier-Waeber M. and Taillefert M. (2008) Remote in situ voltammetric techniques to characterize the biogeochemical cycling of trace metals in aquatic systems. J. Environ. Monit. 10, 30-54.

Turner A. and Millward G. (2002) Suspended Particles: Their Role in Estuarine Biogeochemical Cycles. Estuarine, Coastal and Shelf Science 55, 857-883.

US EPA (Environmental Protection Agency) (2003) Guidance for theDevelopment of Ecological Soil Screening Levels. Office of Solid Waste and Emergency Response, Washington, DC (OSWER Directive 92857-55)

Young, L.B, Dutton, M. and Pick, F.R.(1992) Contrasting two methods for determining trace metal partitioning in oxidized lake sediments. Biogeochem. 17, 205-219.

Wang W. (2002) Interactions of trace metals and different marine food chains. Marine Ecology Progress Series 243, 295-309.

Wang W. and Fisher N. (1999) Delineating metal accumulation pathways for marine invertebrates. Science of The Total Environment 237-238, 459-472.

Wang W.X., Fisher N.S., Luoma S.N. (1996) Kinetic determinations of trace elementbioaccumulation in the musselMytilus edulis. Mar. Ecol. Prog. Ser. 140, 91-113.

Waychunas GA, Kim CS, Banfield JF. Nanoparticulate iron oxideminerals in soils and sediments: unique properties and contaminant scavenging mechanisms. J Nano Res. 2005;7(4-5):409-33.

Wilkie, M.L. and Fortune, S. (2003) Status and trends of mangrove area worldwide. Forest Resources Assessment Working Paper No. 63. Food and Agriculture Organization of the United Nations, Rome.

Wen, L., Shiller, A., Santschi, P.H., and Gill, G. (1999) Trace element behavior in Gulfof Mexico estuaries In: Biogeochemistry of Gulf of Mexico Estuaries (Bianchi, T.S.,Pennock, J.R., and Twilley, R.R., eds.), pp. 303-346, John Wiley, New York

Windom, H.L. and Smith, R. (1985) Factors influencing the concentration and distribution of trace metals in the South Atlantic Bight. In Oceanography of the Southeastern U.S. Continental Shelf, L.P. (eds. Atkinson, D.W. Menzel and K.A. Bush), 141-152. Washington, DC: AGU

Zhou Q. Zhang J., Fu J., Shi J. and Jiang G. (2008) Biomonitoring: An appealing tool for assessment of 
metal pollution in the aquatic ecosystem. Analytica Chimica Acta 606, 135-150.

Zuykov M., Pelletier E. and Harper D. (2013) Bivalve molluscs in metal pollution studies: From bioaccumulation to biomonitoring. Chemosphere 93, 201-208. 


\title{
Chapter 3
}

\section{ZINC STABLE ISOTOPE BIOGEOCHEMISTRY: A REVIEW}

\author{
Daniel Araújo ${ }^{1-2}$
}

\section{Author's filiation}

1- Universidade de Brasília, Instituto de Geociências, Campus Darcy Ribeiro, L2, Asa Norte, Brasília, Distrito Federal, Brazil.

2- Géosciences Environnement Toulouse (GET-UMR 5563 CNRS, Université Paul Sabatier, IRD), 14 Edouard Belin, 31400, Toulouse, France.

\begin{abstract}
Zinc $(\mathrm{Zn})$ is a chacophile metal of Group 12, ubiquitous in the environment and with important participation in many biogeochemical processes that take place in the cellules and in abiotic systems, from the Earth core up to surface environment, and in primitive extraterrestrial materials. In the last 20 years, advances in the mass spectrometry instrumentation have allowed to measure, with precision, the $\mathrm{Zn}$ isotopic fractionation in natural and anthropogenic samples, leading to emergence of the field of $\mathrm{Zn}$ stable isotope biogeochemistry. Supported by a solid theoretical background inherited from the classical non-metal stable isotopes $(\mathrm{C}, \mathrm{N}, \mathrm{H}, \mathrm{O}, \mathrm{N})$, the understanding of the control factors of $\mathrm{Zn}$ isotopic fractionation in the nature have rapidly evolved. Here, we review the main applications and findings of $\mathrm{Zn}$ isotopes in diverse issues of the most variated scientific domains including metal contamination, magmatic differentiation, cosmochemistry, plant uptaking, weathering, global climate changes, dietary and trophic chains and biomedicine. The analytical aspects for their determination in solid and water samples and the mechanisms responsible for the $\mathrm{Zn}$ isotopic fractionation in the nature are also revisited. Thus, we aim to give a general panorama of $\mathrm{Zn}$ isotope biogeochemistry, demonstrating the versatility and potentiality of this isotopic system to elucidate the $\mathrm{Zn}$ elemental cycle through the biogeosphere and in extraterrestrial materials.
\end{abstract}




\section{Graphical Abstract}

\section{Zinc isotope compositons in the nature $\left(\delta^{66 / 64} \mathrm{Zn}_{\mathrm{JMC}}\right)$}

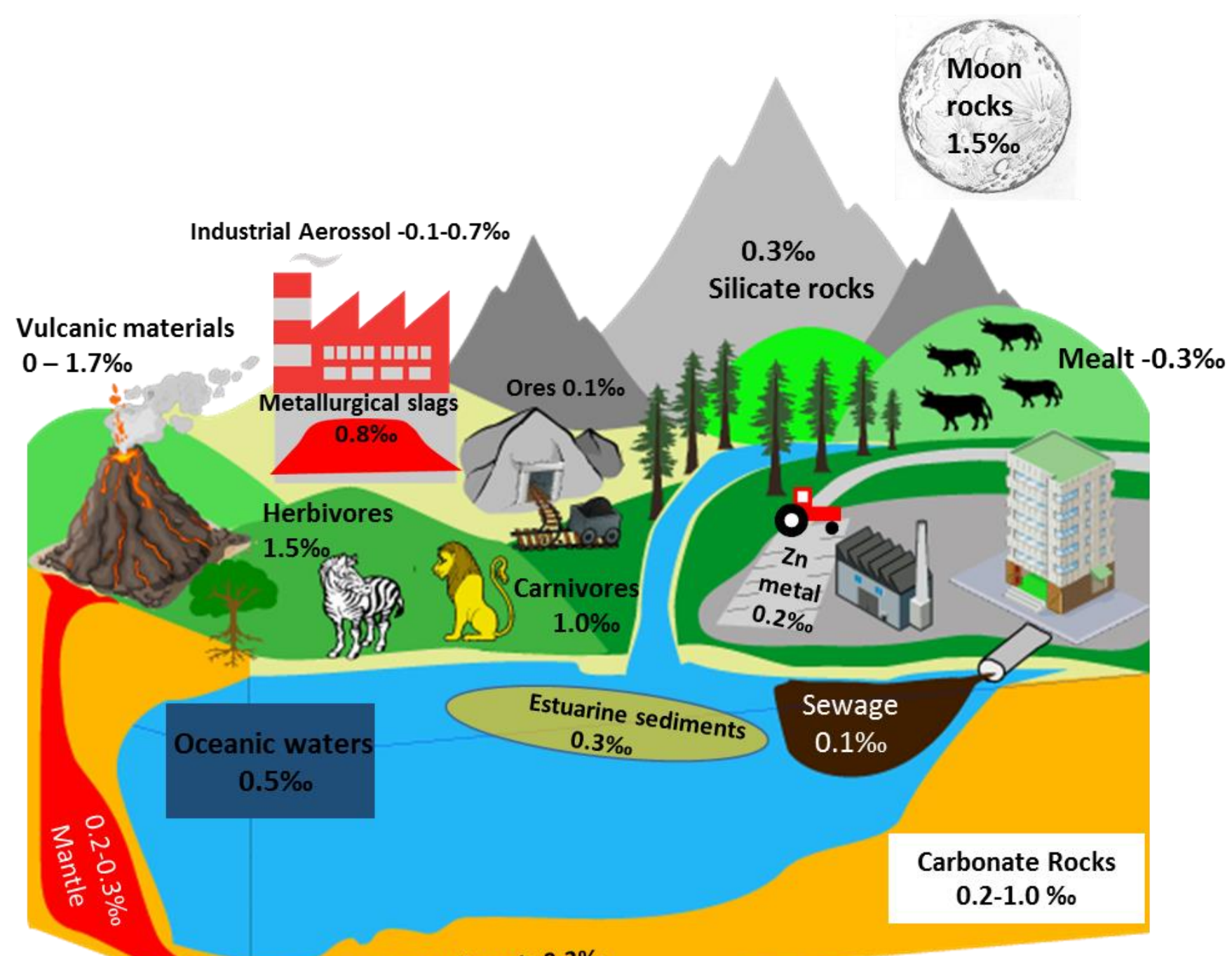

Marine sediments $0.3 \%$ 


\section{Introduction}

In the last 20 years, the metal stable isotopes have been applied in diverse fields of the knowledge such as inorganic chemistry, biomedicine, environmental, anthropology, ecology, climate changes and geology. The main factor of this propulsive scientific interest is the result of the advances in the mass spectrometry instrumentation and sample preparation methods, which allowed to determine precisely the isotopic compositions of metals in natural and manmade materials (Johnson et al., 2004; Bullen and Eisenhauer, 2009; Wiederhold, 2015).

Notoriously, the advent of the multicollector- inductively coupled plasma mass spectrometry (MC-ICP-MS) opened the access to several isotopic systems of periodic table until then unexplored due the analytical limitations or unsuitable techniques of analysis (Johnson et al., 2004; Weiss et al.2007; Bullen, 2011). The MC-ICP-MS present a variety of sample introduction systems (e.g., nebulizer/spray chambers, desolvation, and laser ablation) allowing to work with different matrices and low concentrations (Prohaska et al., 2015). The coupling of the high ionization efficiency of the ICP source, a sector mass analyzer and a double focusing multicollector array system gives it a high sensibility and precision capable to discriminate until small isotopic variations lower 0.1\% in the samples (Becker, 2007; Bullen, 2011). In other hand, the MC-ICP-MS creates some unavoidable obstacles that can hamper precise and accurate measurements such as: (a) the formation of polyatomic species at the ICP source from unwanted molecular ions, (b) potential isobaric interferences from atmospheric and plasma gases, and (c) higher instrumental fractionation or mass bias requiring more rigorous corrections methods. In this way, many laboratories have been struggling to overcome these analytical challenges and today, accurate and precise methods to determine the isotopic compositions are available for many elements (Johnson et al., 2004; Mason et al., 2007; Prohaska et al., 2015)

Amidst the new disponible isotopic systems, increasing interest has been addressed to $\mathrm{Zn}$ isotopes because of the relevance of this element for healthy, economic, technological and environmental studies (Weiss et al., 2007; Adriano and Adriano, 2011; Bullen, 2011). It is an essential micronutrient for organisms and an important cofactor of several enzymes. In high concentrations however, it can be toxic (KabataPendias, 2008; Adriano and Adriano, 2011). This metal is used in alloys, pesticides and 
electroplating and is commonly associated with mining environmental impacts (Sivry et al.,2008; Yin et al.2015).

In this review, the $\mathrm{Zn}$ isotope biogeochemistry is presented, including the general methodological aspects of metal isotope analysis, mechanisms of isotope fractionation and the main applications and findings of $\mathrm{Zn}$ isotopes in themes including metal contamination, magmatic differentiation, cosmochemistry, plant uptake, weathering, global climate changes, dietary and trophic chains, and biomedicine.

\section{General Biogeochemistry of Zinc}

Zinc ( $\mathrm{Zn}$, atomic number 30) is a chacophile metal of Group 12 (d-block), the $24^{\text {th }}$ most abundant element in Earth's Crust, ubiquitous in the environment and with important participation in diverse biogeochemical processes in the cellular metabolism and abiotic compartments of terrestrial and aquatic systems. With more than 200 zinc enzymes known, this metal plays vital functions for the living beings, including the provisioning of structural integrity to several metabolically important proteins (Cloquet et al., 2006; Hansch and Mendel, 2009). In an adult human, about $2 \mathrm{~g}$ of $\mathrm{Zn}$ are distributed throughout the body, composing important enzymes such as carbonic anhydrase and carboxypeptidase A (Cloquet et al., 2006). This great usefulness in biological systems is accounted for by a combination of chemical properties. The electronic configuration of $\mathrm{Zn}$ is $[\mathrm{Ar}] \mathrm{d}^{10} \mathrm{~s}^{2}$, but in the nature is found as a divalent ion (i.e, $\mathrm{Zn}^{2+}$ ) through the loss of the valence shell electrons (Adriano and Adriano, 2011). Because its d-shell orbital is filled, the zinc atom has a ligand-field stabilization energy of zero in all coordination geometries, and hence the lack of an energy barrier to access different coordination geometries can be used by zinc metalloenzymes to alter the reactivity of the metal ion and catalyze many biochemical reactions (Reilly, 2004). Since $\mathrm{Zn}$ serves as micronutrient for almost all living beings, the organisms have evolved mechanisms to supply their needs regardless the external concentration, maintaining the $\mathrm{Zn}$ homeostasis (Bird, 2015). However, in environments containing $\mathrm{Zn}$ at concentrations either so high or so low that overcome the organism's ability to regulate it, undesirable effects may occur (Bird, 2015). Dietary deficiency on $\mathrm{Zn}$ have been associated to deleterious effects on immune system, while high concentrations have been linked to poisoning of individuals, causing nausea, abdominal cramping, vomiting, tenesmus, and diarrhea with or without bleeding (Salgueiro, 2000; Reilly, 2004). 
Zinc is found primarily combined with sulfur and oxygen, in the form of sulphide or oxide associated. The principal ores of $\mathrm{Zn}$ are composed of sphalerite and wutzite, $\mathrm{ZnS}$, of the same chemical formula but with distinguished crystallographic structures, cubic and hexagonal, respectively. Other important ores are zincite $(\mathrm{ZnO})$, smithsonite $\left(\mathrm{ZnCO}_{3}\right)$, willemite $\left(\mathrm{Zn}_{2} \mathrm{SiO}_{4}\right)$ and hemimorphite $\left(\mathrm{Zn}_{4} \mathrm{Si}_{2} \mathrm{O}_{7}(\mathrm{OH})_{2} \cdot \mathrm{H}_{2} \mathrm{O}\right.$. Considering only the mass of the zinc contained in the ores, the world reserve of zinc is more than 480 million tons (Neves, 2011). These mineral reserves are distributed mainly (more than 70\%) over Australia, China, USA, Mexico, Canada, Peru, Bolivia and Kazakhstan (USGS, 2016). In silicate rocks, Zn occurs as trace element uniformly distributed in magmatic rocks (40-120 ppm), whereas in sedimentary rocks it is likely to be concentrated in argillaceous sediments comprising the range of 80-120 ppm. In coal, $\mathrm{Zn}$ concentrations varies from 52 to $19,000 \mathrm{ppm}$. Mean $\mathrm{Zn}$ for worldwide soils is calculated as 64 ppm (Kabata-Pendias, 2008). In the ocean, Zn displays nutrient-like depth profiles (Mason, 2013), generally with lower concentrations at surface water and higher in deep waters, reflecting intense removal of this element into phytoplankton and posterior regeneration at depth. It has been suggested, based on laboratory studies, that Zn could limit phytoplankton growth (Shaked et al., 2006).

Most of the $\mathrm{Zn}$ produced ( $95 \%$ ) in the world comes from ores containing $\mathrm{Zn}$ sulfide minerals (http://www.zinc.org). As Zn ores normally contain 5-15\% zinc, they are concentrated first by crushing and grounding to enable optimal separation from the other minerals. Typically, a zinc concentrate contains about $55 \%$ of zinc and $25-30 \%$ or more of sulfur as well as different amounts of iron, lead, silver and other minerals. Today, over $90 \%$ of global metal $\mathrm{Zn}$ is produced hydrometallurgically in electrolytic plants (http://www.zinc.org). First, ore concentrate is brought to a temperature of more than $900^{\circ} \mathrm{C}$, so the zinc sulfide $(\mathrm{ZnS})$ converts into the more active zinc oxide $(\mathrm{ZnO})$. Then, the zinc oxide is separated from the other calcines by dissolution in sulfuric acid (Yin et al.2015). After some purification steps, the sulfuric leached passes through an electrolytic cell, where an electrical current is circulated through it by applying an electrical difference between the anode and the cathode, causing the zinc to deposit on the cathodes (zinc.org, 2016). Most part of the refined zinc produced is used as a coating to protect iron and steel from corrosion (galvanized metal), as well as alloying metal to make bronze and brass and zinc-based die casting alloy (USGS, 2016). Other secondary applications of $\mathrm{Zn}$ compounds are as catalyst in several chemical production 
(e.g., rubber, pigments, plastic, lubricants, and pesticides) and as component in technological devices such as batteries, television-screen phosphors and automotive equipment (Bullen, 2011).

The large disturbances in the natural $\mathrm{Zn}$ cycle associated to its exploitation, production and releasing by anthropogenic activities, such as vehicle emission, sewage sludge, road runoff, industrial emission and mining and metallurgy, have led to an enrichment of this element in soils, air, waters, sediments and biota (John et al., 2007; Weiss et al.2007; Chen et al.2009; Juillot et al., 2011; Yin et al., 2015). The inputs to atmosphere have been increased by $25 \%$ for $\mathrm{Zn}$ due anthropogenic activities and these impact on rainwater chemistry has been clearly demonstrated in large cities and even in regions far from industrial centers (Gaillardet et al., 2003; Mason, 2013). In addition to these emissions related to human activity, a natural Zinc cycling continues uninterruptedly through the environment due to the natural processes of weathering and erosion (Kabata-Pendias, 2008; Adriano and Adriano, 2001). All these processes mobilize a variety of $\mathrm{Zn}$ compounds in the environment.

\section{Sample preparation for isotope analysis}

\subsection{Solid and water samples}

Collection of solid samples of soils, biological tissues and landfill materials, among others, should be collected into plastic bags, and care should be taken to ensure that sampling equipment (e.g. shovels, augers stem wood borers) does not contain the metal of interest (Gill, 1997; Bullen 2011). The determination of isotope composition of solid samples can be performed in situ using laser ablation techniques, but the conversion to liquid form via acid dissolution for nebulization introduction onto spectrometer is more common. In this last case, the bulk sample should be first crushed to disaggregation in order to facilitate the acid dissolution, as well as homogenized in order to reduce the volume for storage (Gill, 1997). Sediments and soils normally require drying (e.g, at $60^{\circ} \mathrm{C}$, disaggregation and sieving $(<63 \mu \mathrm{m}$ and $<2 \mathrm{~mm}$, respectively). Rocks are crushed and grinded into fine power using agate, swing or ball mill. In case of biological tissues such as plants, bivalves, fish and other organisms, water removal by freeze drying is crucial to avoid sample deterioration (Gill, 1997). After this pre-preparation, the samples are dissolved totally with concentrated acid mixing of $\mathrm{HF}, \mathrm{HNO}_{3}$ and $\mathrm{HCl}$, 
using preferentially PFA labwares on hot plates. In case of refractories samples, digestion assisted by microwave is more indicated. The reagents employed on the sample preparation must be preferentially of high purity to keep the blank as low possible. The sub-boiling distillation of acids are commonly used to remove impurities of the acid reagents.

The sampling protocol for transition or post-transition metal isotope analysis of water is similar to that for standard dissolved cation analysis (Bullen, 2011). The sample is collected using plastic tubing for pumps or plastic containers for dipping and placed into plastic containers that have been rinsed several times with the water being collected. Pre-cleaning of the plastic containers with nitric acid is required to assure lower blanks. The water sample needs to be filtered passing through membranes with pore-size normally varying between 0.45 and $0.22 \mu \mathrm{m}$ (Chen et al., 2008; Bullen, 2011). Depending on scientific purposes, the ultra-centrifugation can be an option to separate the colloidal phase for analysis. After obtaining the dissolved fraction, this should be acidified with nitric or hydrochloric acid to a $\mathrm{pH}$ of approximately 2.0 for sample preservation (APHA, 2005). Knowledge of metal concentrations in the sample prior to collection for isotope analysis is useful in order to ensure that sufficient metal is collected to meet the requirements of the analytical technique. The minimum amount of $\mathrm{Zn}$ required for isotope analysis ranges from as $100 \mathrm{ng}$ to $1000 \mathrm{ng}$, depending on factors such as ionization efficiency in the mass spectrometer, instrumental settings and laboratorial blank (Bullen, 2011). After collection, water samples can be dried and afterwards digested with acids for posterior analyte separation and analysis (Borrok et al.,2007). In case of very diluted waters or marine waters which present high degree of dissolved solids, the dryness method for concentration become unfeasible. As alternative, pre-concentration methods can be performed using specifics resin such as BioRad Chelex ${ }^{\circledR} 100$ column or by co-precipitation adding basic compounds to water samples (Bermin et al., 2006).

All chemical procedures of sample dissolution and $\mathrm{Zn}$ chromatographic separation (discussed on the next section) are normally conducted in clean laboratory enable with class 100-1000 hoods. 


\subsection{Analyte separation: eliminating matrix interferences}

Prior to mass spectrometry, the metal of interest must be isolated from the rest of the sample matrix and particularly from elements that would produce isobaric interferences on the target masses for analysis (Becker, 2005). To this end, the ion exchange chromatography separation is the technique more widely used (Marèchal et al.1999; Chapman et al., 2006; Bullen, 2011). It consists in eluting the sample in the liquid form (mobile phase) through a specific resin packed in a column (stationary phase), where the analyte of interest will be retained while other the matrix elements are lixiviated (Collins et al., 2006). The principle of the technique is based on the different specifics affinities of the ions between the mobile and the steady phase, which depends on the charge/ratio of the ions in the mobile phase and the dipole moment of functional groups in the steady phase (Collins et al., 2006). The adsorption of ion on the stationary phase are reversible, being adjusted by $\mathrm{pH}$ and ionic strength (Skoog, 2000). For separating metal transition elements like $\mathrm{Zn}, \mathrm{Cu}$ and $\mathrm{Fe}$, it is usual to use the anionic type, in which analyte is converted from free ion to complexes chlorides or bromides of negative charge in acid hydrochloric or acid bromidic medium (Maréchal et al., 1999; Borrok et al., 2009). Because the ion-exchange process between the eluted metals and resin can fractionate $\mathrm{Zn}$ isotopically, a recovery close to $100 \%$ is required to avoid a significant change of original isotope compositions of the samples (Maréchal and Albarède, 2002). That process requires a prior calibration and tuning of chromatography protocol to assure reliable data after isotope measurements.

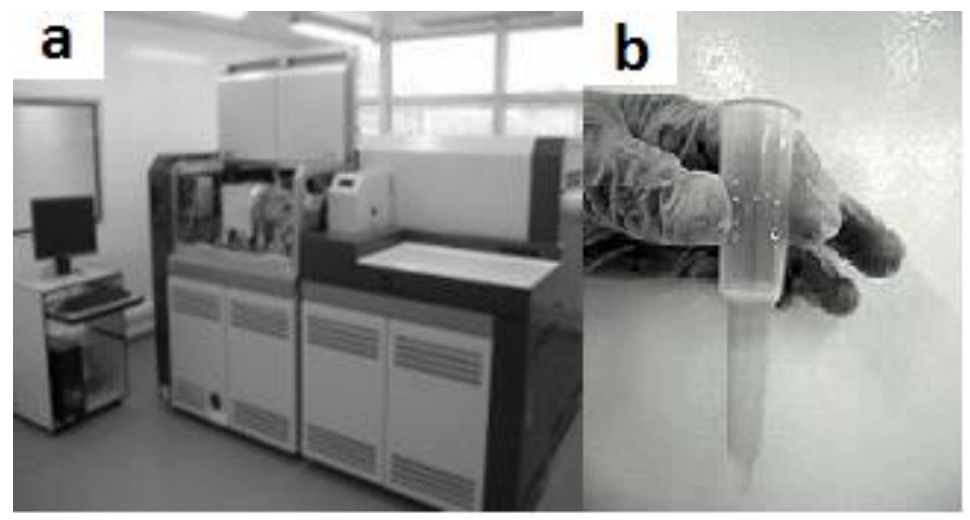

Fig.1. a) A multicollector-inductively coupled plasma mass spectrometry (MC-ICP-MS) from the laboratory of Estudos Geodinâmicos e Ambientais (University of Brasília); b) A chromatographic column packed with ionic exchange resin AG MP-1 (BioRad®). 


\section{The MC-ICP-MS instrumentation}

The MC-ICP-MS is the most suitable analytical instrument to measure the (post-) transition metal isotopic ratios (Fig.2). This instrument consists basically on three main components: ion source, ion optics (ion acceleration, ion beam focusing, and isotope mass separation by magnetic sector) and ion collection by Faraday cups or microionic counters (Becker, 2005; Allègre, 2007).

The sample is injected into the source region either as a nebulized liquid aerosol or as an ablated solid particulate in a gaseous stream which passes through a hightemperature Ar plasma (up to 10,000 K) at near-atmospheric pressure (Johnson et al., 2004). At this high temperature, atoms of the sample material are vaporized, atomized and ionized very efficiently, which works for almost all elements across the periodic table (Johnson et al., 2004). The ions produced then enter the optics region, where they are accelerated through a large potential (up to $10 \mathrm{kV}$ ) and focused electronically to create an ion beam. The accelerated and focused ion beam then passes through a slit into the flight tube where the different isotopes of the element are reflected and separated by the magnetic sector (Allègre, 2007). This slit allows only ions with an energy within an acceptable range to be transmitted in the direction of the magnetic sector (Vanhaecke and Degryse, 2012). By reducing the width of an entrance and exit slit, the mass resolution can be increased to discriminate the analyte ions from interfering species of similar mass (isobaric interferences). High mass resolution is often enabled to resolve some critical interferences like the one from ${ }^{56} \mathrm{Fe}$ derived from polyatomic species formed in the plasma as ${ }^{40} \mathrm{Ar}^{16} \mathrm{O}$. However, the use of narrower slits presents some disadvantages such as the decreasing of analysis sensibility. To counterbalance these effects an electrostatic sector is placed before the magnetic sector in order to improve the ion beam transmission (Vanhaecke and Degryse, 2012). This combination of electrostatic and magnet sector are referred as double-focusing geometry. Most commercially available MC-ICP-MS instruments use a $90^{\circ}$ electrostatic sector immediately after the ion source for velocity focusing, followed by a $90^{\circ}$ magnetic sector. This double-focusing configuration is known as Nier-Johnson geometry (Vanhaecke and Degryse, 2012). The inverse order, i.e, the electrostatic sector placed after the magnetic sector, is known as inverse Nier-Johnson geometry (Fig.2). In the magnetic sector, the magnetic field exerts a perpendicular force onto the ion beam, bending it down according to Lorentz law. The lighter ions 
suffer more deflection than the heavier ones, and so the ions can be sorted according to their mass-to-charge ratio $(\mathrm{m} / \mathrm{z})$. The ion beam deflection is related to the intensity of magnetic field, the radius of the magnet and the voltage applied on the ion extraction (Vanhaecke and Degryse, 2012; Becker, 2005).

Ion detection collectors are set to intersect the resulting flight paths of the ions. The MC-ICP-MS are enabled with Faraday cup detectors: credit-card sized in thin rectangular boxes, open on one narrow end with a deep bucket to receive and trap ions on the internal surfaces, resulting in a measurable total ion current on the internal surfaces (Prohaska, 2011). Made from graphite or graphite-coated metal, Faraday cups are connected to current amplifiers with high-ohmic feedback resistors, typically on the order of $10^{11} \Omega$. These detector are highly robust with large range of linearity and elevated accuracy (Prohaska, 2011; Vanhaecke and Degryse, 2012). Secondary electron multipliers can also be used in cases of extremely low ion currents. Incoming ions strike a conversion dynode that ejects several electrons per incoming ion (Vanhaecke and Degryse, 2012; Prohaska, 2011). These ions are accelerated towards a second conversion dynode where each electron again causes the ejection of several secondary electrons. Several cascading dynode stages result in gains of anywhere from $10^{5}$ - to $10^{8}$ -fold, depending on the voltage bias applied on the device (typically from 500 to 2000 V). Secondary electron multipliers are bulky devices and cannot be placed adjacent to each other in an MC array to allow high-sensitivity ion current detection of neighboring masses. In this case, miniaturized conversion dynodes (channeltrons) that are identical in size with the standard Faraday cups can be inserted directly in the collector array (Prohaska, 2011; Vanhaecke and Degryse, 2012).

An important component in the MC-ICP-MS instrument design is the vacuum system, where several pumping stages are required to maintain an ultra-high vacuum in its inner. Otherwise ions transmitted from ion source will lose their charge by collision with air molecules and return to the atom state deteriorating the instrumental sensitivity (Becker, 2005). In general, a vacuum of $10^{-7}$ millibars near the source, and another vacuum of $10^{-9}$ millibars or lower near the collector is produced via efficient mechanical and electrical "ion getter" vacuum pumps (Prohaska et al., 2011; Vanhaecke and Degryse, 2012). The pumping of the interface is only required if the plasma is in operation. As a consequence, the interface pump is operating separately from the highvacuum system. (Prohaska et al., 2011; Vanhaecke and Degryse, 2012). 
After acquired the $\mathrm{Zn}$ isotope compositions data, it is necessary to correct it, discounting the instrumental fractionation (or mass bias) and drifts that took place during analysis. The mass bias occurs because isotopes are transmitted with different efficiencies by the mass spectrometer, resulting in non-uniform sensitivity across the mass range and in inaccurate isotope ratio measurements (Heumann, 1998; Maréchal et al.1999; Mason et al.2004). The simplest technique used to correct mass bias is sample standard bracketing (SSB), which consists of analyzing an unknown sample "bracketed" by standards that are used to interpolate and correct the mass bias drift during data collection (Archer and Vance, 2004; Peel et al.2008). Another technique widely applied is the external normalization which consists of doping samples and standard with an element with a known isotope composition and similar fractionation behavior to the element being analyzed (e.g. $\mathrm{Zr}$ doping to Mo isotope analysis, $\mathrm{Mg}$ doping for $\mathrm{Si}$ and $\mathrm{Cu}$ doping for $\mathrm{Zn}$ isotope analysis). The measured isotope ratio of the dopant can be compared to its known value to quantify machine-induced fractionation (or factor of fractionation $-f$ ) and a correction can then be applied to the isotope ratio of the target element (Heumann, 1998; Archer and Vance, 2004; Peel et al.2008). A well-established technique that is applicable to any element that has four or more isotopes is the DoubleSpike (DS) technique (Johnson et al., 2004). In the last years, some works have been applied the (DS) technique for $\mathrm{Zn}$ isotopic determinations (Arnorld et al.2008; Moeller et al.2012; Costa-Rodriguez et al.2014) which the main advantages over the standardsample bracketing technique and external normalization are the no requirement of quantitative yields since the mass fractionation that occurs during chemical separation can be corrected for determinations (Johnson et al., 2004; Arnorld et al.2008; Moeller et al.2012; Costa-Rodriguez et al.2014). The main difficult to apply the DS technique are: obtaining pure spikes, determining optimal double spike compositions and double spike-sample mixing proportions, and calibrating the double spike (Johnson et al., 2004; Arnorld et al.2008; Moeller et al.2012; Costa-Rodriguez et al.2014). 


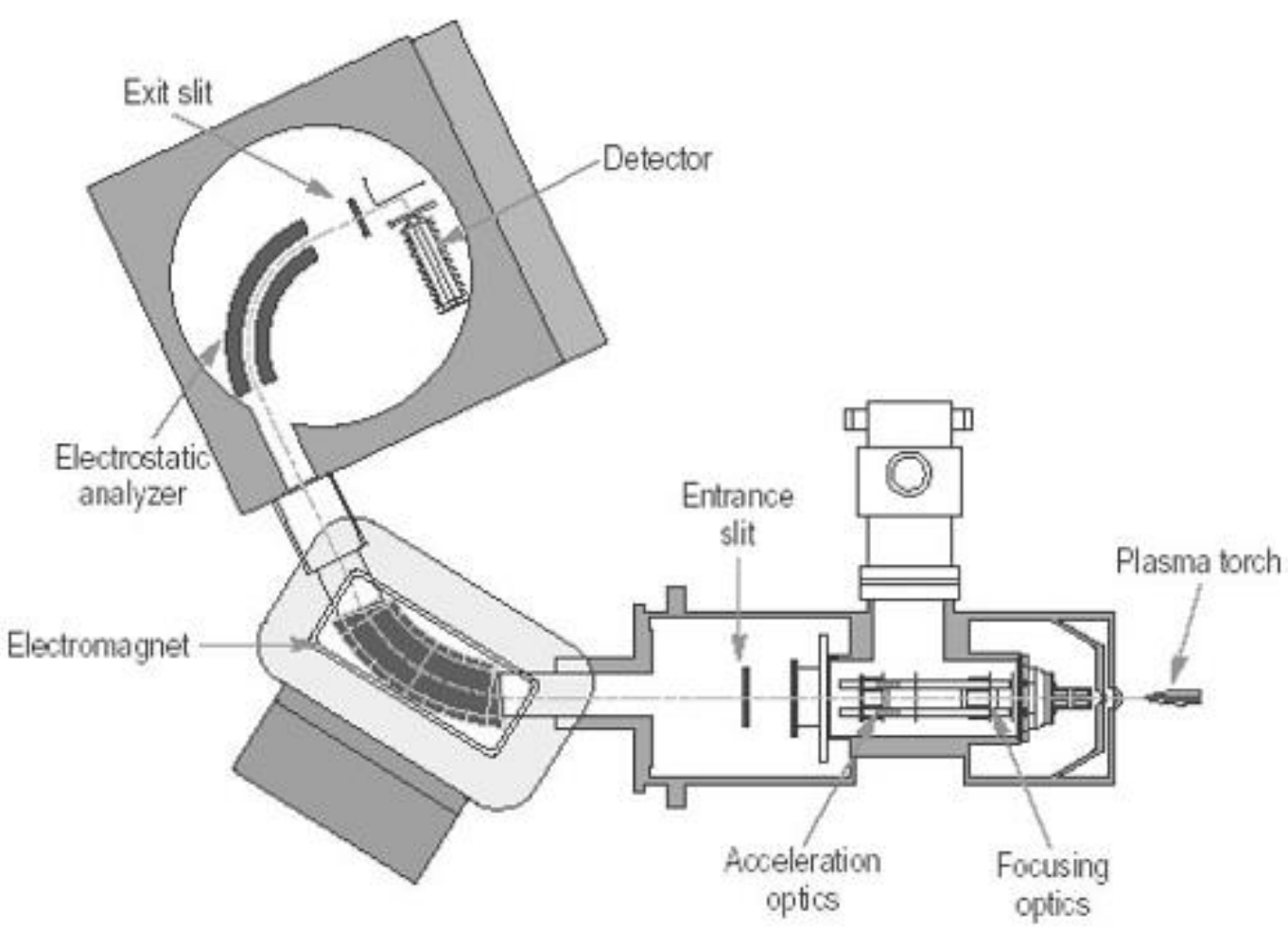

Fig.2. Scheme of a reverse geometry double-focusing magnetic-sector mass spectrometer. Source: Moldovan et al., 2004.

\section{Data reporting and analytical quality control}

The $\mathrm{Zn}$ stable isotope variations are reported as relative values compared with standard reference materials using delta values $(\delta)$ expressed on per mil, which can assume positive or negative values. As the heavy isotope is used in the numerator and the light in the denominator, the ratios more positive are "heavier" compared to the standard ones, while negative values are "lighter". For the $\mathrm{Zn}$ isotopic system, the $\left({ }^{66} \mathrm{Zn} /{ }^{64} \mathrm{Zn}\right)$ ratio is commonly chosen because of the high abundance of these isotopes and are expressed as $\delta^{66 / 64} \mathrm{Zn}$ values as follow:

$$
\delta^{66 / 64} Z n=\frac{\left(\frac{{ }^{66} Z n}{{ }^{64} Z n}\right)_{\text {sample }}}{\left(\frac{{ }^{66} Z n}{{ }^{64} Z n}\right)_{\text {standard }}}-1
$$


The $\delta$-notation are also advantageous because overcome the analytical problem of comparing directly the measured ratios amongst the laboratories, which is difficult to replicate in an accurately and precisely way (Wiederhold, 2015). Establishing a common Standard Reference Materials (SRM) as "zero baseline", it is possible to perform comparisons and calibrations interlaboratories. For the $\mathrm{Zn}$ isotopic system, two certified isotopic reference materials (iCRMs) are available commercially, supplied by the Institute for Reference Materials and Measurements (IRMM-651 and IRMM-3702) (Vogl and Pritzkow, 2012; Irrgeher, 2015). However, the Zn elemental solution JMC 3$0749 \mathrm{~L}$ ("JMC") have been adopted in most of published works within the appurtenant literature, hence was chosen for this work to express the $\mathrm{Zn}$ isotope compositions. Because iCRMs and elemental standards are synthetic solutions, not suitable for sample preparation validation and effect matrix control, many laboratories have analyzed certified reference materials for elemental concentrations, being the most available $\mathrm{Zn}$ isotopic data provided for silicate rocks such as the RMs BHVO-2 basalt, BCR-2 basalt and AGV-2 andesite (Moeller et al.2012). Data for RMs with environmental matrices such as soils, plants, and sediments are still scarce (Araújo et al., 2016). 
Table 1. Main Zinc isotope compositions of reference isotopic standards and reference Materials

\begin{tabular}{|c|c|c|c|}
\hline $\begin{array}{c}\text { Isotopic Standard/ } \\
\text { RMs }\end{array}$ & Reference & $\delta^{66 / 64} \mathrm{Zn} \mathrm{JMC}$ & $\begin{array}{c}N \\
\text { (measurements) }\end{array}$ \\
\hline \multirow[t]{2}{*}{ IRMM-3702 } & Araújo et al., 2016 & $-0.27 \pm 0.07$ & 30 \\
\hline & Sossi et al., 2015 & $-0.30 \pm 0.02$ & \\
\hline \multirow[t]{4}{*}{$\begin{array}{c}\text { BHVO-2 } \\
\text { Basalt }\end{array}$} & Araújo et al., 2016 & $+.25 \pm 0.09$ & 10 \\
\hline & Herzog et al.,2009 & $+0.29 \pm 0.09$ & \\
\hline & Moynier et al., 2009 & $+0.21 \pm 0.09$ & \\
\hline & Moeller et al., 2012 & $+0.48 \pm 0.13$ & 3 \\
\hline \multirow[t]{7}{*}{ BCR-2 } & Araújo et al., 2016 & $+0.25 \pm 0.08$ & 10 \\
\hline & Archer and Vance, 2004 & $+0.20 \pm 0.09$ & 12 \\
\hline & Chapman et al., 2006 & $+0.29 \pm 0.12$ & 8 \\
\hline & Cloquet et al., 2007 & $+0.32 \pm 0.13$ & 2 \\
\hline & Sonke et al., 2008 & $+0.25 \pm 0.04$ & 4 \\
\hline & Herzog et al., 2009 & $+0.33 \pm 0.09$ & \\
\hline & Moeller et al., 2012 & $+0.33 \pm 0.13$ & 3 \\
\hline \multirow[t]{3}{*}{$\begin{array}{c}\text { AGV-2 } \\
\text { Andesite }\end{array}$} & Araújo et al., 2016 & $+0.29 \pm 0.06$ & 2 \\
\hline & Moynier et al., 2009a & $+0.25 \pm 0.09$ & \\
\hline & Chen et al., 2013 & $+0.32 \pm 0.04$ & \\
\hline \multirow[t]{2}{*}{ BCR -482 Lichen } & Weiss et al., 2007 & $+0.14 \pm 0.03$ & 8 \\
\hline & Cloquet et al., 2006 & $+0.07 \pm 0.10$ & 3 \\
\hline $\begin{array}{c}\text { 2709 San Joaquin } \\
\text { Soil }\end{array}$ & Araújo et al., 2016 & $+0.28 \pm 0.10$ & 4 \\
\hline $\begin{array}{c}\text { 1646a Sediment } \\
\text { Estuarine }\end{array}$ & Araújo et al., 2016 & $+0.32 \pm 0.06$ & 4 \\
\hline $\begin{array}{c}\text { 1573a } \\
\text { Tomate Leaves }\end{array}$ & Araújo et al., 2016 & $+0.79 \pm 0.09$ & 4 \\
\hline $\begin{array}{c}\text { BCR-176 } \\
\text { Incineration Fly Ash }\end{array}$ & $\begin{array}{l}\text { Gonzalez and Weiss, } \\
2015\end{array}$ & $-0.17 \pm 0.13$ & 45 \\
\hline $\begin{array}{c}\text { Nod-P-1 Manganese } \\
\text { Nodule }\end{array}$ & Chapman et al., 2006 & $+0.78 \pm 0.09$ & 9 \\
\hline BCR-027 Blend Ore & Chapman et al., 2006 & $+0.33 \pm 0.07$ & 8 \\
\hline
\end{tabular}




\section{Metal isotope fractionation mechanisms}

Physical, chemical and biological processes (e.g., evaporation, melting, crystallization, diffusion, complexation, adsorption, precipitation, cell membrane transportation, etc.) can affect the relative abundance of stable isotopes of an element between the reactant and product phases (Hoefs, 2009). This isotope effect is named isotopic fractionation and occurs on account of the quantum mechanical effects associated to differences on the energy levels of vibrational frequency of bonds between the isotopes and adjacent ligands (Fig.3, McSween et al., 2003). The vibrational frequency of a bond is inversely proportional to its mass, hence if two stable isotopes of an element are distributed randomly in molecules of the same substance, the vibrational frequency associated with bonds to the lighter isotope will be greater than that with bonds to the heavier one (Fig.3, Hoefs, 2009; McSween et al., 2003). In this way, molecules formed with the light isotope will more likely to react than molecules with the heavier one. These different reactivities of light and heavy isotopes result in a partition of them between products and reactants. The enrichment in the heavy or light isotope in a certain reservoir must always be balanced by a corresponding depletion in another reservoir, in such way the isotopic mass balance of the overall system remains unchanged (Allègre, 2008). The magnitude of isotopic fractionation is proportional to the mass differences amongst the isotopes of an element, excepting when the isotopic fractionation is ruled by processes independent of mass as occurs for S and Hg (Hoefs, 2009; Wilderhold, 2015). The latter, nonetheless, is out of the scope of this review.
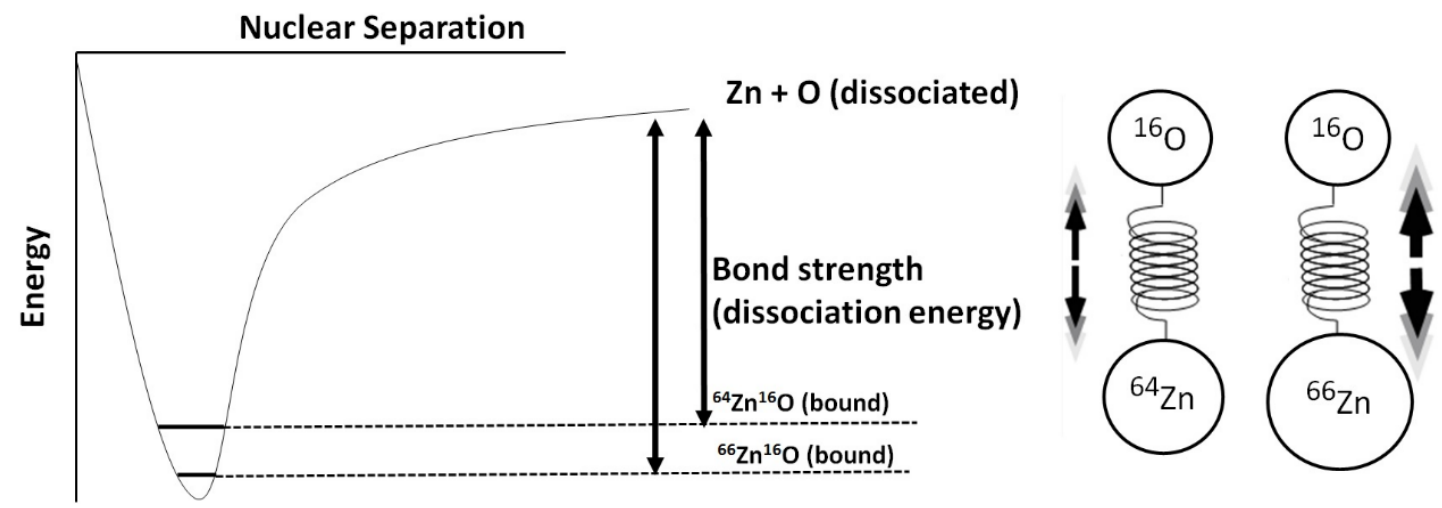

Fig.3. Zinc isotope fractionation during chemical reactions is fundamentally a quantum chemical phenomenon that arises from differences in the basal energies between chemical bonds of the isotopes. The bond between atoms in a molecule can be modeled as a spring. The vibration frequency $(f)$ of a ${ }^{64} \mathrm{Zn}-$ ${ }^{16} \mathrm{O}$ bond is higher than the vibration frequency of a ${ }^{66} \mathrm{Zn}-{ }^{16} \mathrm{O}$ bond, and therefore, is broken faster than the bond of the heavy isotope. 
The mass-dependent isotope fractionation can undergo by two main mechanism: kinetic and equilibrium. The first occurs in irreversible and unidirectional reactions like evaporation, dissociation reactions, biologically mediated reactions, and diffusion. The kinetics fractionation favor the formation of products enriched in the light isotope because bonds with the lighter isotope are broken faster in collation to bonds involving the heavy isotope (Weiss et al., 2007; McSween et al., 2003). The influence of kinetic effects on the sample isotopic composition depends strongly on the relative extent of reaction progress. The largest effects are observed in remaining reactants that can be strongly enriched in heavy isotopes due to the continuous preferential removal of light isotopes, especially when reactions have proceeded far toward completion (Allègre, 2008). The isotopic equilibrium fractionation involves the redistribution (or exchange) of isotopes of an element amongst various species or compounds during a chemical equilibrium reaction, in which the heavy isotopes are enriched in the compounds thermodynamically more stable or with stronger bonding (Wiederhold, 2015). As rule of thumb, the enrichment of the heavy isotope is expected in compounds that present higher degree of oxidation (ions of high charge tend to form more stable bonds), low spin electronic configuration and lower number of coordination (Anbar and Rouxel, 2007). In the equilibrium state, the rates of forward and backward reactions are identical and the equilibrium isotope effect tends to decrease as temperature increases, in most case proportional to $1 / \mathrm{T}^{2}$ (Allègre, 2008; Wiederhold, 2015).

The partitioning of two stable isotopes of an element in two substances or phases controlled by equilibrium or kinetics is described by the isotopic fractionation factor $\alpha$ (Allègre, 2008):

$$
\alpha=\frac{R_{B}}{R_{A}} \quad \text { eq. } 2
$$

where $R_{A}$ and $R_{B}$ are the ratios of heavy to light isotopes in the substance or phases $A$ and $B$, respectively. In general, the equilibrium fractionation factor $\left(\alpha_{\mathrm{eq}}\right)$ is smaller than the kinetic fractionation factor $\left(\alpha_{\text {kin }}\right)$. Because $\alpha$ is very close to 1 , it can be related to $\delta$ values by the simplified equations $\alpha$ (Allègre, 2008):

$$
10^{3} \ln \alpha_{B-A} \approx \delta^{i / j} X_{B}-\delta^{i / j} X_{A} \approx \Delta^{i / j} X_{B-A} \quad \text { eq. } 3
$$


where $\delta^{\mathrm{i} / j} \mathrm{X}_{\mathrm{A}}$ and $\delta^{\mathrm{i} / \mathrm{j}} \mathrm{X}_{\mathrm{B}}$ are the $\delta$ values of substances or phases $\mathrm{A}$ and $\mathrm{B}$, respectively; and the isotope pair $\mathrm{i}$ and $\mathrm{j}$ corresponding to heavier (numerator) and light isotopes (denominator), respectively; $\Delta^{\mathrm{i} / j} \mathrm{X}_{\mathrm{B}-\mathrm{A}}$ is the fractionation between phases $\mathrm{A}$ and $\mathrm{B}$.

Given a fractionation factor, isotopic compositions of reactants and products can usually be calculated once it have been known if the reaction is reversible and if it is an open or a closed system. In a closed-system equilibrium the isotopic difference between products and reactants will be controlled by the fractionation factor $(\alpha)$ and a mass balance will be taken account $\alpha$ (Weiss et al.,2007; Allègre, 2008). In this case, the $\delta^{\mathrm{i} / j} \mathrm{X}_{\mathrm{B}}$ at a given fraction of $\mathrm{A}$ is described as:

$$
\delta^{i / j} X_{B}=\delta^{i / j} X_{o}+\Delta^{i / j} X_{B-A} \cdot f_{A}
$$

Where $\delta^{i / j} \mathrm{X}_{\mathrm{o}}$ is the initial $\delta$ value of the substance $\mathrm{B}$ and $\mathrm{f}_{\mathrm{A}}$ is the elemental fraction of the substance or phase A (Fig.4).

To describe the evolution of isotope ratios during incomplete unidirectional reactions, either controlled by kinetic or equilibrium mechanism, in which the product is physically removed or prevented from isotopically interacting with the reactant, the Rayleigh model is employed (Hayes, 2004). This model is expresses as:

$$
\left(\frac{\delta^{i / j} X_{A}+1000}{\delta^{i / j} X_{O}+1000}\right)=f^{(\alpha-1)}
$$

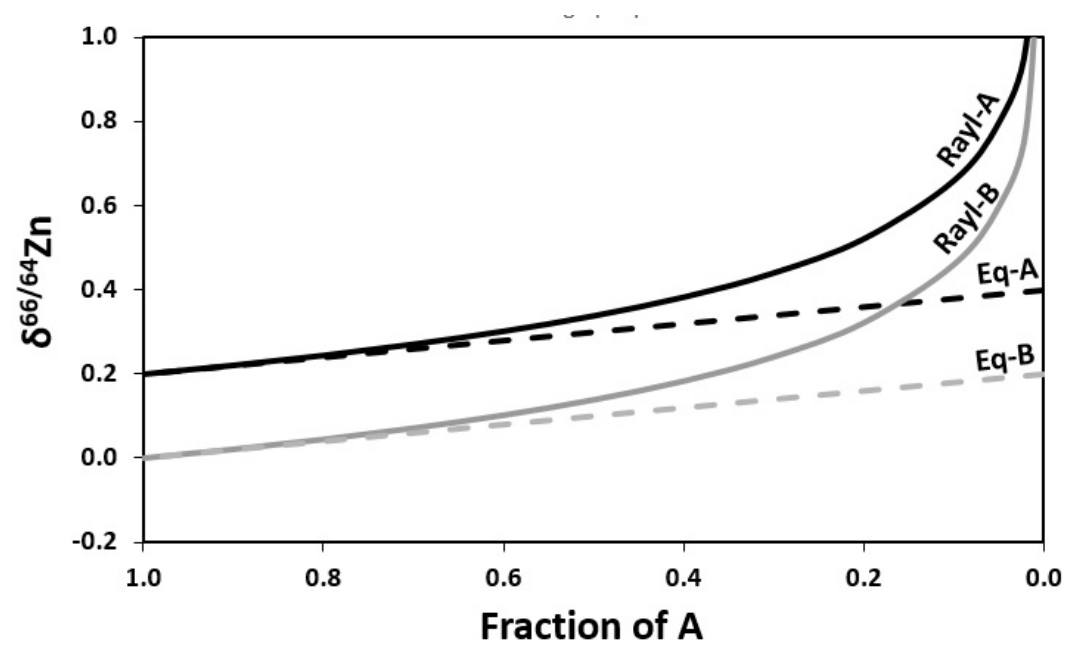

Fig.4. A hypothetic isotopic fractionation during a reaction where phase A reacts to phase B, under (1) equilibrium conditions in a closed system (Eq-A and Eq-B, dotted lines)and (2) unidirectional conditions (Ral-A and RalB, solid lines). The initial isotope ratio of the system is $0.2 \%$ (only phase A is present), and the fractionation factor is $-0.2 \%$; thus $\alpha_{\mathrm{B}-\mathrm{A}}=0.998$. 


\section{Zinc isotopic fractionation in natural and anthropogenic processes}

7.1 High temperature igneous processes and extraterrestrial materials

Zinc isotopic variation on silicate rocks (including igneous, metamorphic and sedimentary) are small and tend to cluster within a narrow range of $+0.20-+0.40 \%$ o (Chapman et al.2006; Cloquet et al.2006; Herzog et al.2009; Moynier et al.2009; Chen et al.2013). Investigations on suites of volcanic rocks have shown that high temperature igneous induces fractionations no larger than $0.10 \%$ and, therefore, $\mathrm{Zn}$ isotopes seems limited to reveal planetary formation and differentiation processes (Chen et al.2013). Based on that findings and assuming a homogenous Earth's mantle and that $\mathrm{Zn}$ is not partitioned into the core, a $\mathrm{Zn}$ isotope composition for the bulk Earth estimated in $+0.28 \pm 0.05 \%$ o $(2 \sigma)$ have been proposed (Chen et al.2013). Despite this overall restricted $\mathrm{Zn}$ isotopic range for rocks, cases of geological settings with contrasting $\delta^{66 / 64} \mathrm{Zn}$ values have been reported (e.g, Taiwan orogen), which can enable the use of $\mathrm{Zn}$ isotopes as tracer for sedimentary provenance (Bentahila et al., 2004). The very homogenous $\mathrm{Zn}$ isotopic composition of the Earth is most likely the result of large-scale melting, mixing and differentiation events that occurred in the terrestrial mantle during and post-accretion (Chen et al.2013).

In other hand, as $\mathrm{Zn}$ is a moderately volatile element (condensation temperature of $\sim 730 \mathrm{~K}), \mathrm{Zn}$ isotope signatures have a large potential to explore evaporationcondensation processes in actively degassing volcanoes, planetary bodies as lunar sample and shocked rocks from terrestrial impact crater as tektites. At Merapi Vulcano degassing, the gas cooling from 590 to $297{ }^{\circ} \mathrm{C}$ is accompanied by a decreasing on $\mathrm{Zn}$ concentrations of gaseous phase, which become gradually enriched in the light $\mathrm{Zn}$ isotope, while the condensates become progressively enriched in the heavier isotopes (Toutain et al., 2008). Gas and condensate isotopic compositions could be explained by a Rayleigh condensation model (Toutain et al., 2008). The $\delta^{66 / 64} \mathrm{Zn}$ of lunar basalt is $\sim 1 \%$ heavier than terrestrial basalt, suggesting that this fractionation occurred during a large-scale evaporation event, likely related to the giant impact that originated the Moon (Paniello et al.,2012). Tektites samples showed also broader $\delta^{66 / 64} \mathrm{Zn}$ values than terrestrial crust, encompassing from lighter values of +0.3 until anomalous values of $+2.49 \%$. All these values were negatively correlated to the elemental abundance of $\mathrm{Zn}$, 
evidencing the isotopic fractionation occurred by evaporation during the heating event upon tektite formation (Moynier et al.2009b).

Investigations on $\mathrm{Zn}$ isotope compositions of meteorites showed $\delta^{66 / 64} \mathrm{Zn}$ values spread over a range of $+0.3 \%$ for carbonaceous chondrites, $2 \%$ for ordinary chondrites, and 4\%o for irons (Luck et al.2005; Brigdestock et al., 2014). All meteoritic and terrestrial samples plot on the same mass dependent fractionation line which implies that $\mathrm{Zn}$ from the inner Solar System formed from a single isotopically homogeneous reservoir (Luck et al., 2005). For CI chondrites, the $\delta^{66 / 64} \mathrm{Zn}$ values of $+0.46 \pm 0.08 \%$ o have been attributed as the best estimate for the primordial $\mathrm{Zn}$ isotope composition of solar system (Barrat et al., 2012). The large range of $\mathrm{Zn}$ isotope compositions observed in the most part of primitive meteorites is thought to be related to variable mixing of isotopically distinct components in the case of the carbonaceous chondrites (Luck et al., 2005), and in the case of the ordinary and EL enstatite chondrites, related to thermal reworking on parent bodies (Moynier et al., 2011). In turn, Ureilites samples which showed a range of $\delta^{66 / 64} \mathrm{Zn}$ values about $0.7 \%$, and a negative correlation between the elemental abundance of $\mathrm{Zn}$ and $\delta^{66 / 64} \mathrm{Zn}$ values, which evidences isotopic fractionation occurred by evaporation during the heating event on the ureilite parent body by possible impacts (Moynier et al., 2011).

\subsection{Pedogenesis and soil-plant system}

Soils present larger range of isotope compositions in relation to the parental rock variation from -0.18 to $0.55 \%$ (unpolluted soils, Fekiacova et al.,2015), which can be attributed to combination of natural abiotic and biological processes in the redistribution of $\mathrm{Zn}$ into different soil horizons during the pedogenesis (Viers et al.2007). Due to the inherent complexity of pedogenesis processes, pattern on $\mathrm{Zn}$ isotopic signatures between horizons are difficult to stablish, but a general tendency to $\delta^{66 / 64} \mathrm{Zn}$ values centered on $0.1 \%$ and on $0.2 \%$ in the $\mathrm{B}$ and $\mathrm{O}$ horizons, respectively, have been noticed (Fekiacova et al.,2015). The isotopic composition of soil profile from Central Siberia is rather constant with a $\delta^{66} \mathrm{Zn}$ value around $0.2 \%$ close to the value of various basalts (Viers et al., 2015). The processes of humicafication that take place in the Siberian soils leads the preferential retention of heavier $\mathrm{Zn}$ and the releasing of the lighter isotopes in solution, preserving the heavy isotopes in the humification products. (Viers et al., 2015). 
In addition to the pedogenesis, the several, chemical reactions of soils change the $\mathrm{Zn}$ speciation and consequently its isotope composition. A study of $\mathrm{Zn}$ isotopes combined with EXAFs spectroscopy in a soil wetland system observed that tetrahedral $\mathrm{Zn}$ species were enriched in heavy isotopes $(+0.33 \%$ ), whereas octahedral $\mathrm{Zn}$ compounds were enriched in light isotopes (-0.04\%) (Aucour et al., 2013). Such results have important implications to source tracing since the isotopic signatures of sources can potentially be overprinted by biogeochemical processes. For example, Juillot et al.(2011) suggested alterations post deposition of anthropogenic isotopic signatures of $\mathrm{Zn}$ in smelter-impacted soils triggered by pedological processes and vegetation influence.

Moreover, the geochemistry of soils are largely affected by the plants which may accelerate chemical weathering by a factor of 2 to 5 (Berner et al. 2004) and act as important pump recycling metals through the biogeosphere (Blackenburg, 2009). Previous studies have demonstrated significant $\mathrm{Zn}$ isotopic fractionation on the continuum soil-plant (Viers et al.2007) and large isotopic variations during uptake, translocation and distribution of $\mathrm{Zn}$ between the internal compartments of plants (Jouvin et al., 2012; Caldelas et al., 2011; Moynier et al., 2009; Weiss et al., 2005; Viers et al., 2007). The magnitude and direction (toward light or heavy isotopic compositions) are related to the interspecies specificities, uptake strategies (types I and II), nutritive solution concentration, elemental speciation, ligands, transpiration flow and height (Weiss et al.2005; Moynier et al.2009; Arnold et al.2010 Caldelas et al., 2011; Jouvin et al.2012; Couder et al.2015). Models of the $\mathrm{Zn}$ transference across the root cell membrane have been based in kinetic fractionations with preferential incorporation of light isotope via diffusion in low-affinity plants; or with preferential heavy isotope incorporation via Zn complexation in carrier-mediated transport (e.g, ZIP - Zinc/Ironregulated Protein) in high-affinity pathways (Jouvin et al.2012). The preferential adsorption of the heavy isotope on cell wall of roots also seems to induce lighter isotope into solution. The pattern of $\mathrm{Zn}$ isotopic compositions in plant may also vary depending on the toxic conditions of the grown medium, where chelation and compartmentation preferential of the heavy isotope of $\mathrm{Zn}$ exceed in the roots would leader to a lighter isotopic pool of the $\mathrm{Zn}$ translocated to aerial compartments. These results were consistent with the pattern of $\mathrm{Zn}$ isotope compositions of plants grew in laboratory using as substrate contaminated soils from a metallurgic site (Couder et al., 2016). 


\subsection{Aquatic systems}

The weathering and erosion of soils and rocks constitute the main source of sediments to aquatic sediments. Thus, both fluvial and terrestrial sediments seems to inherit the lithogenic $\mathrm{Zn}$ isotope composition: $\delta^{66 / 64} \mathrm{Zn}=+0.31 \pm 0.04 \%$ o $(2 \sigma, \mathrm{n}=4)$ for the background areas of Lot Watershed in France (Sivry et al.2008); $\delta^{66 / 64} \mathrm{Zn}=+0.31$ $\pm 0.09 \%$ o $(2 \sigma, \mathrm{n}=4)$ for background area of Lommel in Belgium (Sonke et al.2008); $\delta^{66 / 64} \mathrm{Zn}=+0.23 \pm 0.08 \%$ ( $(2 \sigma, \mathrm{n}=20)$ for marine sediments and $+0.28 \pm 0.02 \%$ o $(2 \sigma, \mathrm{n}=3)$ for sapropels (Marèchal et al.2000). In turn, the $\mathrm{Zn}$ dissolved pool of rivers and estuaries show large range of $\delta^{66 / 64} \mathrm{Zn}$ values varying from -0.57 (Rio Grande, USA, Szynkiewicz and Borrok,2016) to $+0.90 \%$ (Gironde, France, Petit et al., 2015), associated to the multiplicity of biogeochemical processes involving the $\mathrm{Zn}$ transport in waters.

Amongst them and of pivotal importance on the mobility of $\mathrm{Zn}$ in aqueous systems are the sorption processes. Thus, many works have investigated on controlled experiments the isotopic effects related to the aqueous solid interactions in variable $\mathrm{pH}$ values and ionic strength conditions. Overall, the results demonstrate that the adsorption of $\mathrm{Zn}$ on solid surface (such as mineral particles and membranes) generally lowers the $\delta^{66 / 64} \mathrm{Zn}$ of dissolved $\mathrm{Zn}$ in solution because of the preferential incorporation of heavier $\mathrm{Zn}$ isotopes in adsorbed phase (Pokrovsky et al., 2005; Gélabert et al., 2006; Balistrieri et al., 2008; Juillot et al., 2008; Kafantaris and Borrok, 2014; Bryan et al., 2015; Guinoiseau et al., 2016). At surface of clay minerals (kaolinite), the fractionation between the adsorbed pool and the solution $\left(\Delta^{66 / 64} \mathrm{Zn}_{\text {adsorbed-solution }}\right)$ ranged from $0.11 \%$ at low $\mathrm{pH}$ and low ionic strength to $0.49 \%$ at high $\mathrm{pH}$ and high ionic strength. The $\mathrm{Zn}$ isotopic fractionation at the surface of iron oxides with respect to coexisting solution

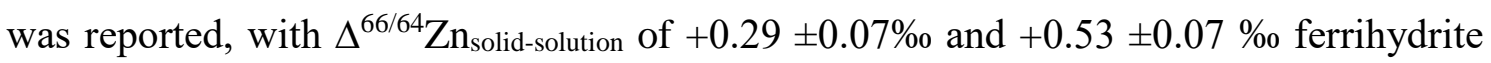
(Balistrieri et al., 2009; Juillot et al., 2008). For $\mathrm{Zn}$ adsorption on birnessite (manganese oxides), $\mathrm{Zn}$ isotopes showed limited fractionation at low ionic strength, while heavy $\mathrm{Zn}$ isotopes are sorbed preferentially at high ionic strength $\left(\Delta^{66 / 64} \mathrm{Zn}_{\text {solid-solution }}\right.$ from 0.52 to $0.77 \%$, Bryan et al., 2015). Regarding organic matter, $\mathrm{Zn}$ binds to the phenolic sites of purified humic acid with a $\Delta^{66 / 64} \mathrm{Zn}_{\text {solid-solution }}=0.24 \pm 0.06 \%$ (Jouvin et al., 2011).

In agreement with the laboratorial findings, a field work on Rio Grande (USA) performed by Szynkiewicz and Borrok (2016) have reported that increase in water $\mathrm{pH}$ from 7.5 to 8.5 lead to a considerable decrease in the $\delta^{66 / 64} \mathrm{Zn}$ of dissolved $\mathrm{Zn}\left(\mathrm{R}^{2}\right.$ 
$=-0.37, \mathrm{p}=0.003, \mathrm{n}=22$ ), and to a isotopic fractionation average between the adsorbed and dissolved pool ( $\Delta^{66 / 64}$ Znadsorbed-dissolved) of $+0.31 \%$. However, in disagreement with these last findings, in the Gironde estuary, the dissolved $\mathrm{Zn}$ showed an enrichment in heavy isotopes due to the preferential light isotope sorption onto suspended particulate matter, maybe associated to kinetically driven adsorption caused by the strongly increasing of sorption sites in water mixing zone of the estuary (Petit et al.2015).

Other laboratorial experiments have shown significant $\mathrm{Zn}$ isotopic fractionation during chemical diffusion, precipitation and biological incorporation by the phytoplankton. Veeramani et al.(2015) showed increasing trend to heavier values of $\delta^{66 / 64} \mathrm{Zn}$ in solution during sphalerite $(\mathrm{ZnS})$ formation, but decreasing trend in $\delta^{66 / 64} \mathrm{Zn}$ during the precipitation of hydrozincite $\left(\mathrm{Zn}_{5}\left(\mathrm{CO}_{3}\right)_{2}(\mathrm{OH})_{6}\right)$ and hopeite $\left(\mathrm{Zn}_{3}\left(\mathrm{PO}_{4}\right)_{2} \cdot 4 \mathrm{H}_{2} \mathrm{O}\right)$. An experimental study by John et al. (2007) reported the $\mathrm{Zn}$ isotope compositions of intracellular $\mathrm{Zn}$ in cultured diatoms. Low $\mathrm{Zn}$ concentrations in media drove high-affinity uptake and a more negative isotope fractionation effect $\left(\Delta^{66 / 64} \mathrm{Zn}_{\text {cells- }}\right.$ medium $=-0.8 \%$ o) compared to low affinity transport when more $\mathrm{Zn}$ was available $\left(\Delta^{66 / 64} \mathrm{Zn}_{\text {cells-medium }}=-0.2 \%\right)$.

In the ocean, data from the Southern ocean, North Atlantic and North Pacific, are strikingly homogeneous, with an average $\delta^{66 / 64} \mathrm{Zn}=+0.53 \pm 0.14 \%$ o $(2 \sigma= \pm 0.03, \mathrm{n}=$ 21). The surface Southern Ocean is more variable, with $\delta^{66 / 64} \mathrm{Zn}$ ranging from +0.07 to $+0.80 \%$. A common thin horizon at 40-80 m Southern ocean, North Atlantic and North Pacific with lighter $\delta^{66 / 64} \mathrm{Zn}$ values close $+0.3 \%$ have been attribute to the preferential biological uptake of the light isotope. Then, the primary activity and the removal of the light isotope have been evoked to explain the heavier isotopic compositions of authigenic marine sediment, including $\mathrm{Fe}-\mathrm{Mn}$ nodules $\left(\delta^{66 / 64} \mathrm{Zn}=+0.90 \pm 0.28 \%\right.$; Maréchal et al., 2000), biogenic carbonates $\left(\delta^{66 / 64} \mathrm{Zn}=0.91 \pm 0.24 \%\right.$; Pichat et al., 2003), and biogenic opal ( $\delta^{66 / 64} \mathrm{Zn}=0.76-1.47 \%$; Andersen et al., 2011). However, estimates on mass balance between inputs and outputs of $\mathrm{Zn}$ isotopes on the oceans do not match, appointing that a missing light sink is still to be located (Little et al., 2014).

The biological isotope fractionation have also been evoked to explain the temporal variations of $\delta^{66 / 64} \mathrm{Zn}$ values in particulate matter from a temperate Swiss lake (Lake Greifen, Peel et al., 2009). These samples showed distinct variations from -0.66 to $+0.21 \%$ with the highest negative values observed after the spring productive period, 
among June and September and most positive values from May to July. The observed temporal pattern is consistent with the preferential uptake of the lighter $\mathrm{Zn}$ isotopes during photosynthesis and incorporation of $\mathrm{Zn}$ into the algal material, which result in in the depletion of $\mathrm{Zn}$ in the surface waters and at same time the enrichment of the heavier $\mathrm{Zn}$ isotopes in the residual dissolved and particulate $\mathrm{Zn}$ pool (according to Rayleigh distillation dynamics). At the end of productive period, the algal detrital material enriched in the light isotope pass to contribute to bulk particulate matter, leading the particulate $\mathrm{Zn}$ pool to lighter isotope compositions.

\subsection{Paleoclimate}

Since assimilatory uptake of $\mathrm{Zn}$ appears to fractionate its isotopes, $\mathrm{Zn}$ isotope ratios measured in carbonate precipitated seems reflect fluctuations in primary productivity (Pichat et al.2003). Zinc isotopic data from a Neoproterozoic cap dolostone (the Nuccaleena Formation in the Flinders Ranges, South Australia) have been interpreted as a two-stage evolution of the deglacial ocean pos snow ball event (Fig.5). Slightly ${ }^{66} \mathrm{Zn}$ enriched values at the base of the cap dolostone indicate immediate resumption of the biological pump upon melting of the surface ocean, but this signal was diluted by intense surface runoff that drove $\delta^{66 / 64} \mathrm{Zn}$ values down to the composition of continentally derived $\mathrm{Zn}$. A subsequent rise in $\delta^{66 / 64} \mathrm{Zn}$ values seem records a vigorous increase in primary production (associated to the removal of light isotope) and export from a nutrient-laden surface ocean. 


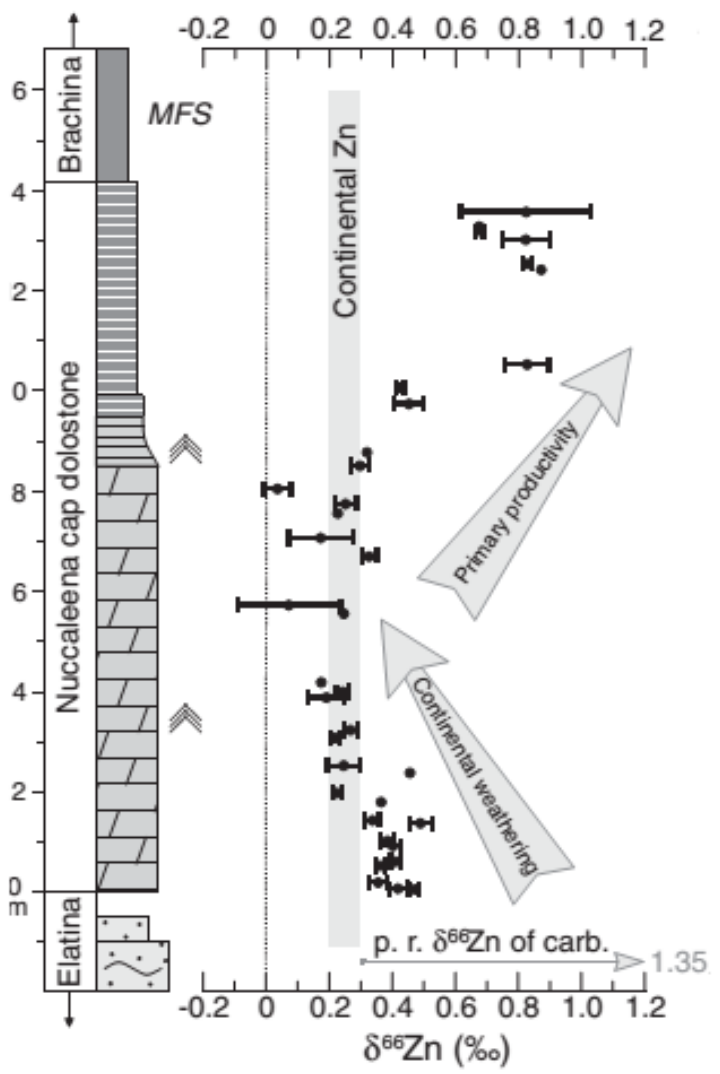

\section{Purple shale}

Shale with dolostone beds

Dolostone with shale beds

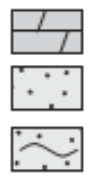

Buff-yellow dolostone

Sandstone

Flaser-bedded sandstone
Giant wave ripple

Maximum flooding

MFS surface

Fig.5. Lithostratigraphy and isotope chemostratigraphy of the investigated Nuccaleena cap dolostone section.

7.5 Ore deposits, coal and industrial and metallurgical processes

Some $\mathrm{Zn}$ isotope studies have been conducted in ore deposits like on the Alexandrinka volcanic-hosted massive sulfide deposit (Mason et al. 2005), the carbonate-hosted Zn$\mathrm{Pb}$ deposits of the Irish Midlands ore field (Wilkinson et al. 2005; Crowther 2007), the Red Dog shale-hosted base metal deposit (Kelley et al. 2009), and modern submarine hydrothermal systems (John et al. 2008). All these studies showed that the $\mathrm{Zn}$ isotope composition of sphalerite is controlled by the composition of the source-rock(s), and, temperature-related and kinetic fractionation during precipitation of sulfides (Pasava et al.,2014). Based on a compilation of data set published in the literature for $\mathrm{Zn}$ ores sulfides, Sonke et al.(2008) calculated an average of $\delta^{66 / 64} \mathrm{Zn}$ of $+0.16 \pm 0.20 \%$ o $(2 \sigma, \mathrm{n}=$ 10 mines, $n=61$ analyses). Coal and Coal mixture with fuels tire-derived present 
$\delta^{66 / 64} \mathrm{Zn}_{\text {JMC }}$ values from +0.13 to +0.88 (Borrok et al., 2010; Gonzalez and Weiss; 2016). Such range in coal is suggested be related to different $\mathrm{Zn}$ speciation and diagenetic processes in the precursor material of the coal (Gonzales and Weiss, 2016).

The isotopic signatures of feed ores and coals have important implications to final products and byproducts produced in metallurgic and coal-fired power plants. High temperature processes employed during sulfide ores smelting and coal combustion induce significant isotope fractionation (Fig.6), with lighter $\mathrm{Zn}$ isotopes entering the vapor phase and leaving the residual material (e.g fly ash particles, slags) enriched with the heavier isotopes according to the Rayleigh's law (Sivry et al., 2008; Borrok et al., 2010; Yin et al., 2015; Gonzalez and Weiss, 2016). In case of ores refining, the additional electroplating step also seems affect the $\mathrm{Zn}$ isotope fractionation, as demonstrated in controlled electrochemical experiments (Kavner et al.,2008, Black et al., 2011; Black et al., 2014) and evidenced in analysis of contaminated sediment by metallurgic slags (Sivry et al., 2016). Apart these gaps concerning the electrochemistry effects on industrial plants, a general trend have been observed in $\mathrm{Zn}$ extraction of sulfide ores: the production of air emissions with the lightest signature $\left(\delta^{66 / 64} \mathrm{Zn}=\right.$ $0.66 \%$, Mattielli et al., 2009), slags with the heaviest $\left(\delta^{66 / 64} \mathrm{Zn}=1.49 \%\right.$, Sivry et al., 2008) and final products (refined $\mathrm{Zn}$ electroplated materials) with isotope compositions close to the ores $\left(\delta^{66 / 64} \mathrm{Zn}=0.22 \%\right.$, Yin et al., 2015). The significant difference in the isotopic compositions derived of anthropogenic sources compared to the natural background (soils and rocks, for example) have enable $\mathrm{Zn}$ isotopes as a powerful tracer of sources capable of discriminate and quantify several pollutant sources concerning mining and metallurgy byproducts (Dogolopova et al., 2006; Mattielli et al., 2006; Weiss et al., 2007; Sivry et al., 2008), and others such as vehicle emissions and tire wear (Gioia et al., 2008; Thapalia et al., 2015), and wastewaters and sewage (Chen et al., 2008; 2009). 


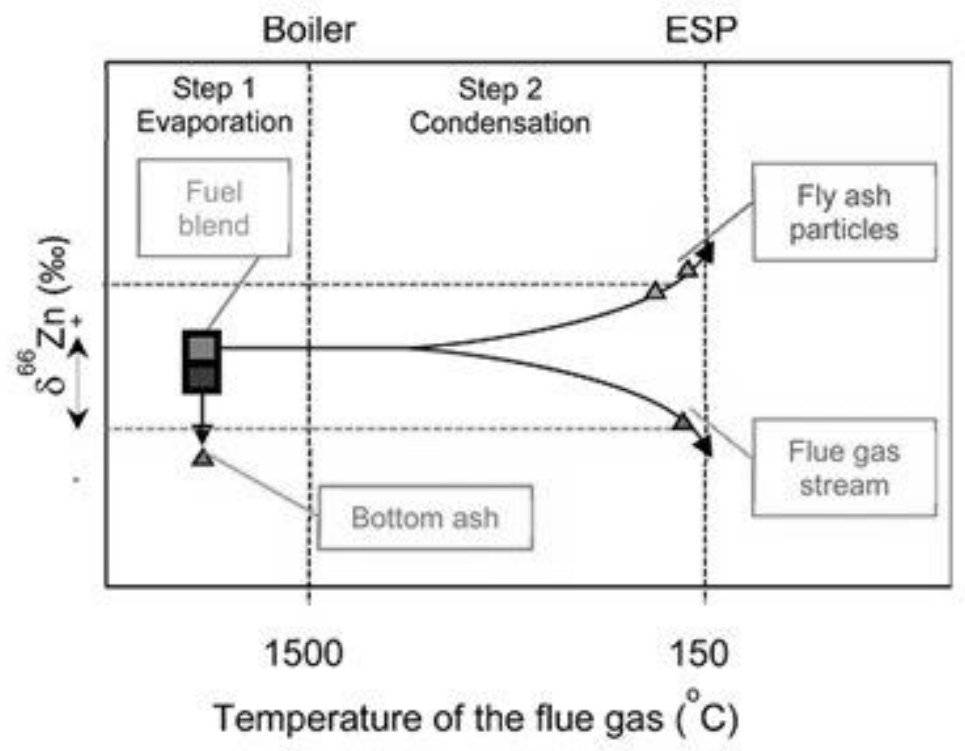

Fig.6.Conceptual model for predicting $\mathrm{Zn}$ isotopic fractionation during coal combustion, after pass by the boiler and electrostatic precipator (ESP) steps. Source: Gonzalez and Weiss, 2015.

In acid mine drainage (AMD) or acid rock drainage (ARD) context, the zinc isotopic signature of dissolve phase are similar to the original ores (sphalerites for examples) and few correlations with geochemical parameters ( $\mathrm{pH}$, ionic strength, temperature and diel changes) suggests limited fractionation due to ore weathering or and, therefore, $\mathrm{Zn}$ isotopic signatures reflect basically the original source of sulfides minerals

In biomonitoring studies, $\mathrm{Zn}$ isotopes have been determined in tissues of bivalves mollusks as a novel tool, potentially capable of integrating sources, fates, and bioavailability information for detection, evaluation and biomonitoring of environmental contamination (Shiel et al.,2012; Shiel et al.2013; Petit et al.2015). However, its effectiveness for sources tracing remain inconclusive. Studies conducted with bivalves on the west coast in Canada showed homogenous $\mathrm{Zn}$ isotopic signatures that overlapped those of unpolluted soils, sediments and marine water (Shiel et al.,2012). In the Gironde-estuary (a site historically impacted by metallurgy) the isotopic record of oysters seemed to rather reflect adsorption processes along the Maximum Turbid Zone (MTZ) rather than different Zn sources (Petit et al.2015). 
7.6 Dietary, trophic chains and human body

The range of $\delta^{66 / 64} \mathrm{Zn}$ values observed in food products is approximately $1.9 \%$ and the strong differences in the blood Zinc isotopic signatures of vegetarians and omnivores reflect the effects of diet of each group (Costas-Rodríguez et al., 2014). In general, vegetables, cereals and derived products showed an enrichment of the heavier $\mathrm{Zn}$ isotopes, whereas a depletion was observed in products of animal origin (meat, fish, egg and semi-skimmed milk), relative to human blood samples. Thus, the lower $\delta^{66 / 64} \mathrm{Zn}$ values found in food products of animal origin appear to be reflected in the lower $\delta^{66 / 64} \mathrm{Zn}$ value observed in blood from an omnivorous population compared to that from a vegetarian population (Van Heghe et al., 2012; Costas-Rodríguez et al., 2014). Beyond the dietary, correlations between $\mathrm{Zn}$ isotope compositions of blood with age were also found in the isolated population of Yakut (Jaouen et al., 2016). These same sampling showed a discrepant average of $\delta^{66 / 64} \mathrm{Zn}$ value in comparion to European and Japanese poluations, which can be associated to different metabolic rates (Jaouen et al., 2013). The lighter $\delta^{66 / 64} \mathrm{Zn}$ values in the food of animal origin seems to reflect the isotopic fractionation that take place along the trophic chains. In African terrestrial food webs, $\delta^{66 / 64} \mathrm{Zn}$ values in both bone and dental enamel of carnivore animals were lighter by approximately $0.4-0.5 \%$ in comparison to bones and dental enamel of herbivores. In the analysis of marine mammal bones (walruses, bearded seals, ringed seals and polar bears), the $\delta^{66 / 64} \mathrm{Zn}$ values of marine mammal bones also showed a trend toward lighter isotopes compositions with the increasing of trophic level. However, different $\mathrm{Zn}$ isotope pattern were found in terrestrial trophic chain of South Africa, where no significant $\mathrm{Zn}$ isotopic fractionation was observed between bones of herbivores and bones of carnivores (including lion and hyena) (Jaouen et al., 2012).

More studies regarding to internal $\mathrm{Zn}$ isotopic fractionation within animal bodies and the relation between dietary and bioavailability are necessary to understand how $\mathrm{Zn}$ isotope fractionate from low to high trophic steps. For example, the tendency of heavier $\mathrm{Zn}$ isotope compositions of herbivores face to plants have been attributed to the precipitation of $\mathrm{Zn}$ with phytates in the intestine, inhibiting its absorption. This precipitation favors the binding of light $\mathrm{Zn}$ isotopes to the phytates, which implies that heavy $\mathrm{Zn}$ isotopes are more bioavailable (Jaoun et al.,2012). In controlled feeding studies, it have been demonstrated that for modern mammals, muscle tissue and bones have a different $\mathrm{Zn}$ isotopic composition (Moynier et al., 2009; Balter et al., 2013), 
where muscle tissue had ${ }^{66} \mathrm{Zn}$-depleted values compared to the food ( $\Delta^{66 / 64} \mathrm{Zn}_{\text {muscles-food }}$ $\approx-0.2 \%$ ) and bone had ${ }^{66} \mathrm{Zn}$-enriched values $\left(\Delta^{66 / 64} \mathrm{Zn}_{\text {bones-food }} \approx 0.1\right.$ to $0.4 \%$ ). In contrast, a feeding experiment using sheep reported that, for the four animals analyzed, there were similar values between bone and muscle tissue, and both tissues were enriched in heavy isotopes relative to their diet (Balter et al., 2010).

The partition processes of $\mathrm{Zn}$ isotope between tissues and organs within an organism have been also explored to biomedicine purposes such as early diagnostic biomarker for breast cancer. The $\mathrm{Zn}$ isotopic signatures of various tissues in breast cancer patients and controls showed to have a significantly lighter $\mathrm{Zn}$ isotopic composition than those that can be found in blood, serum or healthy breast tissue. This change of isotopic signatures for carcinogenic tissues may be associated to a mechanism of $\mathrm{Zn}$ delivery and posterior $\mathrm{Zn}$-sequestering in vesicles by metallothioneins (Larner et al., 2015). 


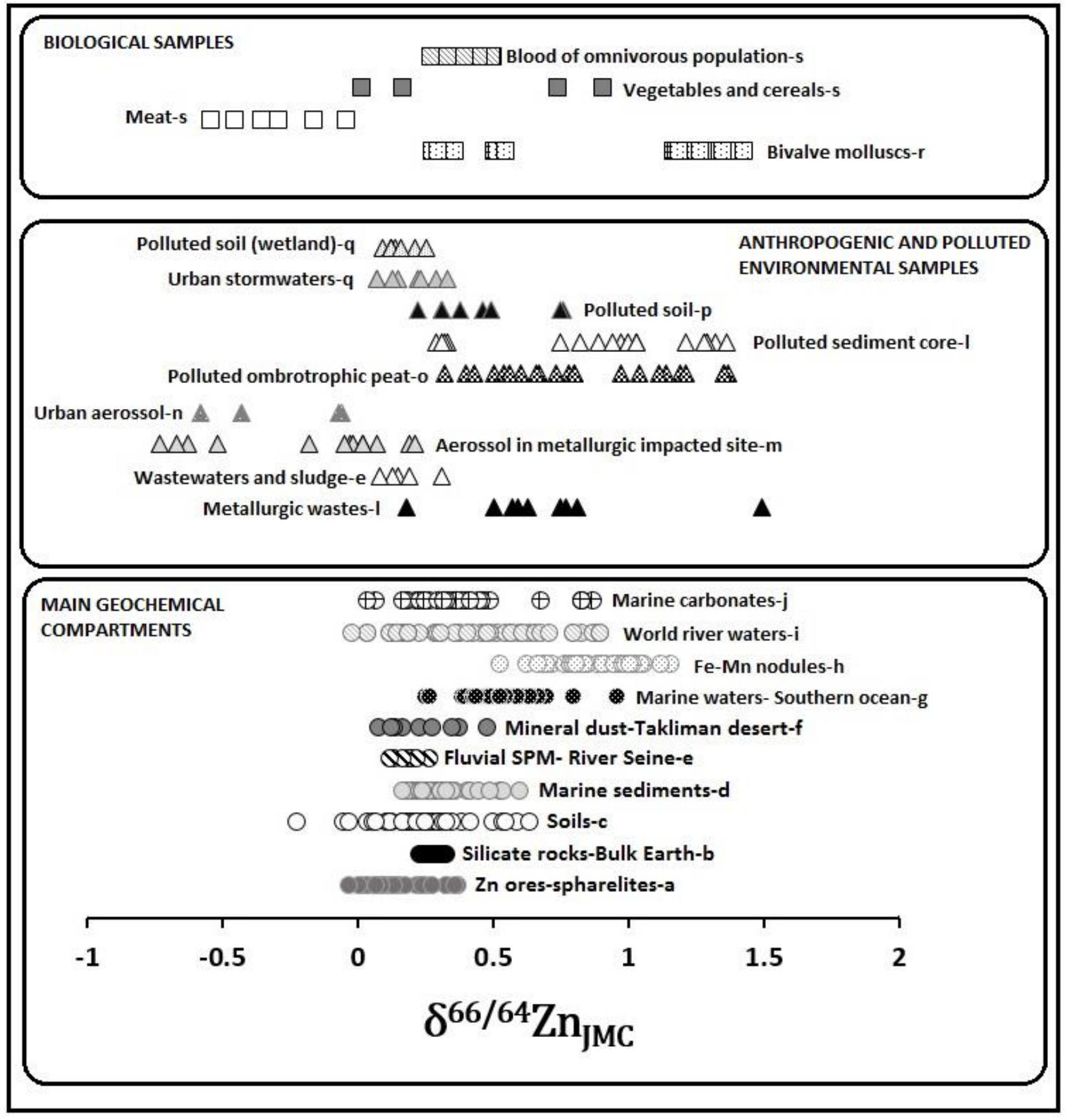

Fig.7. Zinc isotope compositions (expressed relative to JMC standard) of the main geochemical compartments, anthropogenic and environmental polluted samples and biological samples.a-Sonket et al., 2008; b- Chen et al., 2013; cVance et al., 2016 ; Viers et al., 2015; d- Maréchal et al., 2000; Bentahila et al., 2008; e-Chen et al., 2009; f-Dong et al., 2013;g-Zhao et al., 2014; h-Maréchal et al., 2000; i-Little et al., 2014 ; Petit et al., 2015;j-Kuzmann et al., 2012; 1-Sivry et al., 2008; m-Mattielli et al., 2009; n-Gioia et al., 2008 ; o-Weiss et al., 2007; p-Juillot et al., 2011; q-Aucour et al., 2011; r- Shiel et al., 2012; Shiel et al., 2013 ; Petit et al., 2015; s- Costa-rodriguez et al., 2014. 


\section{Conclusions}

The versatility and usefulness of $\mathrm{Zn}$ isotopes is proved by the many applications in different scientific fields, as seen in this review. The current increasing of research groups on metal isotope biogeochemistry will contribute to the continuous developing of the $\mathrm{Zn}$ isotope biogeochemistry, leading to new methodologies and advances in the theoretical understanding about the factors that control its isotopic fractionation in the nature. Challenging, but promising is the coupling between chromatographic separation techniques (GC or HPLC) and the MC-ICP-MS instruments. The isotopic determinations combined with $\mathrm{Zn}$ speciation are an important step forward to the understanding of biogeochemical and environmental cycles, and can open new frontiers in the biomedicine applications, including the establishment of the medical isotope metallomics field.

Future studies are required to link the $\mathrm{Zn}$ speciation and bioavailability and mechanisms of isotopic fractionation during its incorporation to the biota. and subsequent partition within human and animal body. The development of selective or sequential extraction for isotopic analysis of different phases of soils and sediments could be an interesting auxiliary tool for comprehend the isotopic fractionation during uptake. However, more robust and reproducible protocols are required, beyond the verification of possible artifacts associated to the chemical procedure.

Apart from the analytical and methodological advances, additional investigations as into deposit ores, including that with non-sulfidic mineral phases, as occurring in some Brazilian deposits (Vazante, Minas Gerais), may provide new insights into the genesis of ore systems. Concomitant, new efforts to increase the dataset in environmental compartments can contribute to identify sources and sinks of anthropogenic $\mathrm{Zn}$ and its cycling through the biogeosphere, either in local or global scale. Of special concern for aquatic systems is the analysis of the pore waters, since it present important implications to understand diagenetic reactions and bioavailability, mainly in coastal zones and wetlands, where the large gradients of redox conditions promote periodical releasing and trapping of metal on sediments. In biomonitoring context, more tests in other biomonitors organisms must be encouraged to verify the feasibility of $\mathrm{Zn}$ isotopes as monitor of metal contamination. Actually, its use in bivalve molluscs have been hampered by the lack of knowledge about physiological influence 
on the $\mathrm{Zn}$ bioisotopic record. Other gap is related the studies addressed to the agriculture or urban diffuse sources. The legitimacy of $\mathrm{Zn}$ isotopes as a monitoring tool for atmospheric contamination in big cities has already been demonstrated (Gioia et al., 2008), but still demands for more works for a better characterization of anthropogenic and natural sources. At last, new theoretical and controlled experiments regarding the effects of chemistry coordination of $\mathrm{Zn}$ with different ligand will be useful to interpret and predict the isotopic fractionation in the environment and biological systems, encompassing since stratigraphic $\mathrm{Zn}$ profiles along the geological time until cellular metabolism processes.

\section{Acknowledgement}

The author acknowledge the financial support and grants provided by CNPq (Brazilian Research Council, grant numbers: 161944/2012-4 and 211238/2014-7); Dominik Weiss, Wilson Machado and Jeremie Garnier for stimulating scientific discussions; and Ronaldo Leite for his substantial help in the manuscript revision.

\section{References}

Adriano D. and Adriano D. (2001) Trace elements in terrestrial environments. Springer, New York.

Albarède F. (2015) Metal Stable Isotopes in the Human Body: A Tribute of Geochemistry to Medicine.Elements 11, 265-269.

Allègre C. 2008. Isotope geology. Cambridge University Press, Cambridge, UK.

APHA (2005) Standard methods for the examination of water and wastewater. APHA, Washington, DC, USA.

Anbar A. and Rouxel O. (2007) Metal Stable Isotopes in Paleoceanography. Annu. Rev. Earth Planet. Sci. 35, 717-746.

Aranda S., Borrok D., Wanty R. and Balistrieri L. (2012) Zinc isotope investigation of surface and pore waters in a mountain watershed impacted by acid rock drainage. Science of The Total Environment420, 202-213.

Araújo D., Boaventura G., Viers J., Mulholland D., Weiss D., Araújo D., Lima B., Ruiz I., Machado W., Babinski M. and Dantas E. (2016) Ion Exchange Chromatography and Mass Bias Correction for Accurate and Precise Zn Isotope Ratio Measurements in Environmental Reference Materials by MC-ICP-MS. Journal of the Brazilian Chemical Society.

Archer C. and Vance D. (2004) Mass discrimination correction in multiple-collector plasma source mass spectrometry: an example using $\mathrm{Cu}$ and $\mathrm{Zn}$ isotopes. Journal of Analytical Atomic Spectrometry 19, 656.

Arnold T., Kirk G., Wissuwa M., Frei M., Zhao F., Mason T. And Weiss D. (2010) Evidence for the mechanisms of zinc uptake by rice using isotope fractionation. Plant, Cell \& Environment 33, 370381. 
Aucour A., Bedell J., Queyron M., Magnin V., Testemale D. and Sarret G. (2015) Dynamics of Zn in an urban wetland soil-plant system: Coupling isotopic and EXAFS approaches. Geochimica et Cosmochimica Acta 160, 55-69.

Balistrieri L., Borrok D., Wanty R. and Ridley W. (2008) Fractionation of Cu and Zn isotopes during adsorption onto amorphous Fe(III) oxyhydroxide: Experimental mixing of acid rock drainage and ambient river water. Geochimica et Cosmochimica Acta 72, 311-328.

Barrat J., Zanda B., Moynier F., Bollinger C., Liorzou C. and Bayon G. (2012) Geochemistry of CI chondrites: Major and trace elements, and $\mathrm{Cu}$ and $\mathrm{Zn}$ Isotopes. Geochimica et Cosmochimica Acta83, 79-92.

Baskaran M. (2011) Handbook of environmental isotope geochemistry., Springer, Berlin.

Blanckenburg, F. Von, Wirén, N. Von, Guelke, M., Weiss, D. J., \& Bullen, T. D. (2009). Fractionation of Metal Stable Isotopes by Higher Plants, elements (1), 375-380.

Black J., Kavner A. and Schauble E. (2011) Calculation of equilibrium stable isotope partition function ratios for aqueous zinc complexes and metallic zinc. Geochimica et Cosmochimica Acta 75, 769783.

Black J., John S. and Kavner A. (2014) Coupled effects of temperature and mass transport on the isotope fractionation of zinc during electroplating. Geochimica et Cosmochimica Acta 124, 272-282.

Borrok D., Gieré R., Ren M. and Landa E. (2010) Zinc Isotopic Composition of Particulate Matter Generated during the Combustion of Coal and Coal + Tire-Derived Fuels. Environmental Science \& Technology 44, 9219-9224.

Borrok D., Nimick D., Wanty R. and Ridley W. (2008) Isotopic variations of dissolved copper and zinc in stream waters affected by historical mining. Geochimica et Cosmochimica Acta 72, 329-344.

Borrok D., Wanty R., Ian Ridley W., Lamothe P., Kimball B., Verplanck P. and Runkel R. (2009) Application of iron and zinc isotopes to track the sources and mechanisms of metal loading in a mountain watershed. Applied Geochemistry 24, 1270-1277.

Borrok D., Wanty R., Ian Ridley W., Lamothe P., Kimball B., Verplanck P. and Runkel R. (2009) Application of iron and zinc isotopes to track the sources and mechanisms of metal loading in a mountain watershed. Applied Geochemistry 24, 1270-1277.

Borrok D., Wanty R., Ridley W., Wolf R., Lamothe P. and Adams M. (2007) Separation of copper, iron, and zinc from complex aqueous solutions for isotopic measurement. Chemical Geology 242, 400414.

Bridgestock L., Williams H., Rehkämper M., Larner F., Giscard M., Hammond S., Coles B., Andreasen R., Wood B., Theis K., Smith C., Benedix G. and Schönbächler M. (2014) Unlocking the zinc isotope systematics of iron meteorites. Earth and Planetary Science Letters 400, 153-164.

Bryan A., Dong S., Wilkes E. and Wasylenki L. (2015) Zinc isotope fractionation during adsorption onto Mn oxyhydroxide at low and high ionic strength. Geochimica et Cosmochimica Acta 157, 182-197.

Bullen T. and Eisenhauer A. (2009) Metal Stable Isotopes in Low-Temperature Systems: A Primer.Elements 5, 349-352.

Bullen T. and Walczyk T. (2009) Environmental and Biomedical Applications of Natural Metal Stable Isotope Variations. Elements 5, 381-385.

Caldelas C., Dong S., Araus J. and Jakob Weiss D. (2010) Zinc isotopic fractionation in Phragmites australis in response to toxic levels of zinc. Journal of Experimental Botany 62, 2169-2178.

Chen J., Gaillardet J. and Louvat P. (2008) Zinc Isotopes in the Seine River Waters, France: A Probe of Anthropogenic Contamination. Environmental Science \& Technology 42, 6494-6501.

Chen H., Savage P., Teng F., Helz R. and Moynier F. (2013) Zinc isotope fractionation during magmatic differentiation and the isotopic composition of the bulk Earth. Earth and Planetary Science Letters369-370, 34-42.

Cloquet C., Carignan J., Lehmann M. and Vanhaecke F. (2008) Variation in the isotopic composition of zinc in the natural environment and the use of zinc isotopes in biogeosciences: a review. Anal Bioanal Chem 392, 319-319. 
Costas-Rodríguez M., Van Heghe L. and Vanhaecke F. (2014) Evidence for a possible dietary effect on the isotopic composition of $\mathrm{Zn}$ in blood via isotopic analysis of food products by multi-collector ICP-mass spectrometry. Metallomics 6, 139-146.

Couder E., Mattielli N., Drouet T., Smolders E., Delvaux B., Iserentant A., Meeus C., Maerschalk C., Opfergelt S. and Houben D. (2015) Transpiration flow controls Zn transport in Brassica napus and Lolium multiflorum under toxic levels as evidenced from isotopic fractionation. Comptes Rendus Geoscience 347, 386-396.

Coutaud A., Meheut M., Viers J., Rols J. and Pokrovsky O. (2014) Zn isotope fractionation during interaction with phototrophic biofilm. Chemical Geology 390, 46-60.

Fekiacova Z., Cornu S. and Pichat S. (2015) Tracing contamination sources in soils with $\mathrm{Cu}$ and $\mathrm{Zn}$ isotopic ratios. Science of The Total Environment 517, 96-105.

Gaillardet J., Viers J. and Dupré B. (2003) Trace elements in River Waters in: Treatise of Geochemistry (ed. H.D Holland and K.K. Turekain), Elsevier, Amsterdam.

Gélabert A., Pokrovsky O., Viers J., Schott J., Boudou A. and Feurtet-Mazel A. (2006) Interaction between zinc and freshwater and marine diatom species: Surface complexation and $\mathrm{Zn}$ isotopefractionation. Geochimica et Cosmochimica Acta 70, 839-857.

Gioia S., Weiss D., Coles B., Arnold T. and Babinski M. (2008) Accurate and Precise Zinc Isotope Ratio Measurements in Urban Aerosols. Analytical Chemistry 80, 9776-9780.

Gill R. (1997) Modern analytical geochemistry. Longman, Harlow, Essex, England.

Gonzalez R. and Weiss D. (2015) Zinc Isotope Variability in Three Coal-Fired Power Plants: A Predictive Model for Determining Isotopic Fractionation during Combustion. Environmental Science \& Technology 49, 12560-12567.

Guinoiseau D., Gélabert A., Moureau J., Louvat P. and Benedetti M. (2016) Zn Isotope Fractionation during Sorption onto Kaolinite. Environmental Science \& Technology 50, 1844-1852.

Hänsch R. and Mendel R. (2009) Physiological functions of mineral micronutrients (Cu, Zn, Mn, Fe, Ni, Mo, B, Cl). Current Opinion in Plant Biology 12, 259-266.

Hayes, J. M. (2004). An Introduction to Isotopic Calculations. Atomic Energy, (January), 1-10.

Heumann K., M. Gallus S., Rädlinger G. and Vogl J. (1998) Precision and accuracy in isotope ratio measurements by plasma source mass spectrometry. Journal of Analytical Atomic Spectrometry 13, 1001 .

Herzog G., Moynier F., Albarède F. and Berezhnoy A. (2009) Isotopic and elemental abundances of copper and zinc in lunar samples, Zagami, Pele's hairs, and a terrestrial basalt. Geochimica et Cosmochimica Acta 73, 5884-5904.

Hoefs J.(2009) Stable isotope geochemistry. Springer-Verlag, Berlin.

Irrgeher J. and Prohaska T. (2015) Application of non-traditional stable isotopes in analytical ecogeochemistry assessed by MC ICP-MS - A critical review. Anal Bioanal Chem 408, 369-385.

Jaouen K., Beasley M., Schoeninger M., Hublin J. and Richards M. (2016) Zinc isotope ratios of bones and teeth as new dietary indicators: results from a modern food web (Koobi Fora, Kenya). Sci. Rep.6, 26281.

Jaouen K., Gibert M., Lamboux A., Telouk P., Fourel F., Albarède F., Alekseev A., Crubézy E. and Balter V. (2013) Is aging recorded in blood $\mathrm{Cu}$ and $\mathrm{Zn}$ isotope compositions?. Metallomics 5, 10161024.

Jaouen K., Pons M. and Balter V. (2013) Iron, copper and zinc isotopic fractionation up mammal trophic chains. Earth and Planetary Science Letters 374, 164-172.

Jaouen K., Szpak P. and Richards M. (2016) Zinc Isotope Ratios as Indicators of Diet and Trophic Level in Arctic Marine Mammals. PLOS ONE 11, e0152299.

John S., Park J., Zhang Z. and Boyle E. (2007) The isotopic composition of some common forms of anthropogenic zinc. Chemical Geology 245, 61-69.

John, S. G., \& Conway, T. M. (2014). A role for scavenging in the marine biogeochemical cycling of zinc and zinc isotopes. Earth and Planetary Science Letters, 394, 159-167.

http://doi.org/10.1016/j.eps1.2014.02.053 
Johnson, B. Beard, F. Albaréde (2004) Geochemistry of Non-Traditional Stable Isotopes. Mineralogical Society Of America, Washington, DC, 2004.

Jouvin D., Louvat P., Juillot F., Maréchal C. and Benedetti M. (2009) Zinc Isotopic Fractionation: Why Organic Matters. Environmental Science \& Technology 43, 5747-5754.

Jouvin D., Weiss D., Mason T., Bravin M., Louvat P., Zhao F., Ferec F., Hinsinger P. and Benedetti M. (2012) Stable Isotopes of $\mathrm{Cu}$ and $\mathrm{Zn}$ in Higher Plants: Evidence for $\mathrm{Cu}$ Reduction at the Root Surface and Two Conceptual Models for Isotopic Fractionation Processes. Environmental Science \& Technology 46, 2652-2660.

Juillot F., Maréchal C., Morin G., Jouvin D., Cacaly S., Telouk P., Benedetti M., Ildefonse P., Sutton S., Guyot F. and Brown G. (2011) Contrasting isotopic signatures between anthropogenic and geogenic $\mathrm{Zn}$ and evidence for post-depositional fractionation processes in smelter-impacted soils from Northern France. Geochimica et Cosmochimica Acta 75, 2295-2308.

Juillot F., Maréchal C., Ponthieu M., Cacaly S., Morin G., Benedetti M., Hazemann J., Proux O. and Guyot F. (2008) Zn isotopic fractionation caused by sorption on goethite and 2-Lines ferrihydrite. Geochimica et Cosmochimica Acta 72, 4886-4900.

Kabata-Pendias A., (2008) Trace Elements in Soils and Plants. Springer, Berlin.

Kafantaris F. and Borrok D. (2014) Zinc isotope fractionation during surface adsorption and intracellular incorporation by bacteria. Chemical Geology 366, 42-51.

Kavner A., John S., Sass S. and Boyle E. (2008) Redox-driven stable isotope fractionation in transition metals: Application to Zn electroplating. Geochimica et Cosmochimica Acta 72, 1731-1741.

Kunzmann M., Halverson G., Sossi P., Raub T., Payne J. and Kirby J. (2012) Zn isotope evidence for immediate resumption of primary productivity after snowball Earth. Geology 41, 27-30.

Little S., Vance D., Walker-Brown C. and Landing W. (2014) The oceanic mass balance of copper and zinc isotopes, investigated by analysis of their inputs, and outputs to ferromanganese oxide sediments. Geochimica et Cosmochimica Acta 125, 673-693.

Luck J., Othman D. and Albarède F. (2005) Zn and Cu isotopic variations in chondrites and iron meteorites: Early solar nebula reservoirs and parent-body processes. Geochimica et Cosmochimica Acta 69, 5351-5363.

McSween H., Richardson S., Uhle M., Richardson S. (2003) Geochemistry:pathways and processes. Columbia University Press, New York.

Mason T., Weiss D., Horstwood M., Parrish R., Russell S., Mullane E. and Coles B. (2004) Highprecision $\mathrm{Cu}$ and $\mathrm{Zn}$ isotope analysis by plasma source mass spectrometry. Journal of Analytical Atomic Spectrometry 19, 218.

Mattielli N., Rimetz J., Petit J., Perdrix E., Deboudt K., Flament P. and Weis D. (2006) Zn-Cu isotopic study and speciation of airborne metal particles within a 5-km zone of a lead/zinc smelter.Geochimica et Cosmochimica Acta 70, A401.

Moeller K., Schoenberg R., Pedersen R., Weiss D. and Dong S. (2012) Calibration of the New Certified Reference Materials ERM-AE633 and ERM-AE647 for Copper and IRMM-3702 for Zinc Isotope Amount Ratio Determinations. Geostandards and Geoanalytical Research 36, 177-199.

Moldovan M., Krupp E., Holliday A. and Donard O. (2004) High resolution sector field ICP-MS and multicollector ICP-MS as tools for trace metal speciation in environmental studies: a review. $J$. Anal. At. Spectrom. 19, 815-822.

Moynier F., Beck P., Jourdan F., Yin Q., Reimold U. and Koeberl C. (2009) Isotopic fractionation of zinc in tektites. Earth and Planetary Science Letters 277, 482-489.

Moynier F., Beck P., Yin Q., Ferroir T., Barrat J., Paniello R., Telouk P. and Gillet P. (2010) Volatilization induced by impacts recorded in $\mathrm{Zn}$ isotope composition of ureilites. Chemical Geology 276, 374-379.

Moynier F., Blichert-Toft J., Telouk P., Luck J. and Albarède F. (2007) Comparative stable isotope geochemistry of $\mathrm{Ni}, \mathrm{Cu}, \mathrm{Zn}$, and $\mathrm{Fe}$ in chondrites and iron meteorites. Geochimica et Cosmochimica Acta 71, 4365-4379. 
Moynier F., Paniello R., Gounelle M., Albarède F., Beck P., Podosek F. and Zanda B. (2011) Nature of volatile depletion and genetic relationships in enstatite chondrites and aubrites inferred from $\mathrm{Zn}$ isotopes. Geochimica et Cosmochimica Acta 75, 297-307.

Moynier F., Pichat S., Pons M., Fike D., Balter V. and Albarède F. (2009) Isotopic fractionation and transport mechanisms of $\mathrm{Zn}$ in plants. Chemical Geology 267, 125-130.

Paniello R., Day J. and Moynier F. (2012) Zinc isotopic evidence for the origin of the Moon. Nature490, 376-379.

Pašava J., Tornos F. and Chrastný V. (2014) Zinc and sulfur isotope variation in sphalerite from carbonate-hosted zinc deposits, Cantabria, Spain. Mineralium Deposita 49, 797-807.

Pokrovsky O., Viers J. and Freydier R. (2005) Zinc stable isotope fractionation during its adsorption on oxides and hydroxides. Journal of Colloid and Interface Science 291, 192-200.

Peel K., Weiss D. and Siggc L. (2009) Zinc isotope composition of settling particles as a proxy for biogeochemical processes in lakes: Insights from the eutrophic Lake Greifen, Switzerland. Limnol. Oceanogr. 54, 1699-1708.

Peel K., Weiss D., Chapman J., Arnold T. and Coles B. (2008) A simple combined sample-standard bracketing and inter-element correction procedure for accurate mass bias correction and precise $\mathrm{Zn}$ and $\mathrm{Cu}$ isotope ratio measurements. J. Anal. At. Spectrom. 23, 103-110.

Prohaska T. (2015) Sector field mass spectrometry for elemental and isotopic analysis. Royal Society of Chemistry, Cambridge.

Reilly C. (2004) The nutritional trace metals., Blackwell Pub., Oxford, OX, UK.

Sabine Becker J. (2005) Recent developments in isotope analysis by advanced mass spectrometric techniques : Plenary lecture. Journal of Analytical Atomic Spectrometry 20, 1173.

Salgueiro M., Zubillaga M., Lysionek A., Sarabia M., Caro R., De Paoli T., Hager A., Weill R. and Boccio J. (2000) Zinc as an essential micronutrient: A review. Nutrition Research 20, 737-755.

Shaked Y., Xu Y., Leblanc K. and Morel F. (2006) Zinc availability and alkaline phosphatase activity in Emiliania huxleyi: Implications for Zn-P co-limitation in the ocean. Limnol. Oceanogr. 51, 299309.

Shiel A., Weis D. and Orians K. (2012) Tracing cadmium, zinc and lead sources in bivalves from the coasts of western Canada and the USA using isotopes. Geochimica et Cosmochimica Acta 76, 175190.

Shiel A., Weis D., Cossa D. and Orians K. (2013) Determining provenance of marine metal pollution in French bivalves using $\mathrm{Cd}, \mathrm{Zn}$ and $\mathrm{Pb}$ isotopes. Geochimica et Cosmochimica Acta 121, 155-167.

Sivry Y., Riotte J., Sonke J., Audry S., Schäfer J., Viers J., Blanc G., Freydier R. and Dupré B. (2008) Zn isotopes as tracers of anthropogenic pollution from $\mathrm{Zn}$-ore smelters The Riou Mort-Lot River system. Chemical Geology 255, 295-304.

Sonke J., Sivry Y., Viers J., Freydier R., Dejonghe L., Andre L., Aggarwal J., Fontan F. And Dupre B. (2008) Historical variations in the isotopic composition of atmospheric zinc deposition from a zinc smelter. Chemical Geology 252, 145-157.

Sossi P., Halverson G., Nebel O. and Eggins S. (2014) Combined Separation of Cu, Fe and Zn from Rock Matrices and Improved Analytical Protocols for Stable Isotope Determination. Geostandards and Geoanalytical Research 39, 129-149.

Szynkiewicz A. and Borrok D. (2016) Isotope variations of dissolved $\mathrm{Zn}$ in the Rio Grande watershed, USA: The role of adsorption on $\mathrm{Zn}$ isotope composition. Earth and Planetary Science Letters 433, 293-302.

Thapalia A., Borrok D., Van Metre P. and Wilson J. (2015) Zinc Isotopic Signatures in Eight Lake Sediment Cores from Across the United States. Environmental Science \& Technology 49, 132-140.

Thapalia A., Borrok D., Van Metre P., Musgrove M. and Landa E. (2010) Zn and Cu Isotopes as Tracers of Anthropogenic Contamination in a Sediment Core from an Urban Lake. Environmental Science \& Technology 44, 1544-1550.

Toutain J., Sonke J., Munoz M., Nonell A., Polvé M., Viers J., Freydier R., Sortino F., Joron J. and Sumarti S. (2008) Evidence for Zn isotopic fractionation at Merapi volcano. Chemical Geology253, 74-82. 
USGS Mineral Resources Program (2016). Minerals.usgs.gov. Available at: http://minerals.usgs.gov/ [Accessed August 2, 2016].

Vance, D., Matthews, A., Keech, A., Archer, C., Hudson, G., Pett-ridge, J., \& Chadwick, O. A. (2016). The behaviour of $\mathrm{Cu}$ and $\mathrm{Zn}$ isotopes during soil development : Controls on the dissolved load of rivers. Chemical Geology. http://doi.org/10.1016/j.chemgeo.2016.06.002

Vanhaecke F. \& Degryse P. 2012. Isotopic analysis. Wiley-VCH, Weinheim.

Vance D., Matthews A., Keech A., Archer C., Hudson G., Pett-Ridge J. and Chadwick O. (2016) The behaviour of $\mathrm{Cu}$ and $\mathrm{Zn}$ isotopes during soil development: Controls on the dissolved load of rivers.Chemical Geology.

Veeramani H., Eagling J., Jamieson-Hanes J., Kong L., Ptacek C. and Blowes D. (2015) Zinc Isotope Fractionation as an Indicator of Geochemical Attenuation Processes. Environmental Science \& Technology Letters 2, 314-319.

Viers J., Oliva P., Nonell A., Gélabert A., Sonke J., Freydier R., Gainville R. and Dupré B. (2007) Evidence of $\mathrm{Zn}$ isotopic fractionation in a soil-plant system of a pristine tropical watershed (Nsimi, Cameroon). Chemical Geology 239, 124-137.

Viers J., Prokushkin A., Pokrovsky O., Kirdyanov A., Zouiten C., Chmeleff J., Meheut M., Chabaux F., Oliva P. and Dupré B. (2015) Zn isotope fractionation in a pristine larch forest on permafrostdominated soils in Central Siberia. Geochem Trans 16.

Wiederhold J. (2015) Metal Stable Isotope Signatures as Tracers in Environmental Geochemistry.Environmental Science \& Technology 49, 2606-2624.

Yin N., Sivry Y., Benedetti M., Lens P. and van Hullebusch E. (2015) Application of Zn isotopes in environmental impact assessment of $\mathrm{Zn}-\mathrm{Pb}$ metallurgical industries: A mini review. Applied Geochemistry 64, 128-135.

Zhao Y., Vance D., Abouchami W. and de Baar H. (2014) Biogeochemical cycling of zinc and its isotopes in the Southern Ocean. Geochimica et Cosmochimica Acta 125, 653-672. 


\section{Chapter 4}

ION EXCHANGE CHROMATOGRAPHY AND MASS BIAS CORRECTION FOR ACCURATE AND PRECISE Zn ISOTOPE RATIO MEASUREMENTS IN ENVIRONMENTAL REFERENCE MATERIALS BY MC-ICP-MS

Manuscript published as paper in the Journal of the Brazilian Chemical Society, DOI: 10.5935/0103-5053.20160167

Daniel F. Araújo ${ }^{\mathrm{a}-\mathrm{b}^{*}}$; Geraldo R. Boaventura ${ }^{\mathrm{a}}$; Jerôme Viers ${ }^{\mathrm{b}}$; Daniel S. Mulholland Dominik Weiss ${ }^{\mathrm{d}}$; Débora Araújo ${ }^{\mathrm{e}}$; Bárbara Lima ${ }^{1}$; Izabel Ruiz; Wilson Machado ${ }^{\mathrm{g}}$; Marly Babinski ${ }^{\mathrm{f}}$, Elton Dantas ${ }^{\mathrm{a}}$

a- Universidade de Brasília, Instituto de Geociências, Campus Darcy Ribeiro, L2, Asa Norte, Brasília, Distrito Federal, Brazil.

b- Géosciences Environnement Toulouse (GET-UMR 5563 CNRS, Université Paul Sabatier, IRD), 14 Edouard Belin, 31400, Toulouse, France.

c- Universidade Federal do Tocantins, Departamento de Química Ambiental, Rua Badejós, Lote 7, Chácaras 69/72, Zona Rural, Gurupi, Tocantins, Brazil.

d- Imperial College London, Earth Science and Engineering, London, United Kingdom

e- Rio Tinto Exploration, 1 Research Ave Bundoora VIC 3083 Australia.

f- Universidade de São Paulo, Instituto de Geociências, Rua do Lago 562, Cidade Universitária, São Paulo, Brazil.

g- Universidade Federal Fluminense, Departamento de Geoquímica, Campus do Valonguinho, Niterói, Rio de Janeiro, Brazil.

Corresponding author*: Daniel F. Araújo, email:danielunb.ferreira@ gmail.com; phone: +55 (61) 31070142. 


\section{Graphical Abstract}

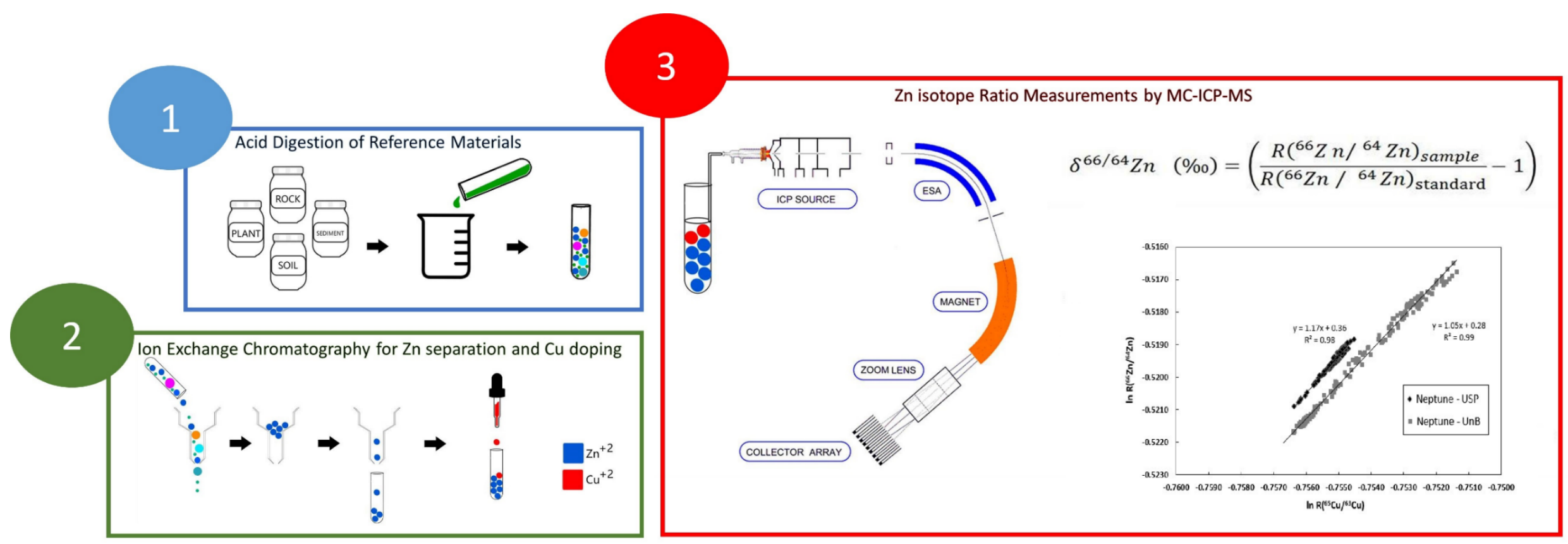

Zinc isotope ratios were determined in soil, plant, rock and sediment reference materials by MC-ICP-MS. The procedure encompassed an improved ion exchange chromatography protocol for a fast and simple $\mathrm{Zn}$ separation, investigations into the instrumental mass bias processes and its correction using different approaches. 


\section{Abstract}

We present precise and accurate $\delta^{66 / 64} \mathrm{Zn}$ data for environmental reference materials (RMs) including rocks, sediments, soils, and plants in order to improve the metrological traceability and analytical control of $\mathrm{Zn}$ isotopes ratio determinations in future environmental studies. We adjusted a previously developed ion exchange chromatography protocols to enable faster sample throughput and investigated the instrumental mass bias processes. The improved chromatographic protocol yielded precise and quantitative recoveries $(99 \pm 7 \%, \sigma, \mathrm{n}=16)$, while the mass bias correction using $\mathrm{Cu}$ as external dopant provided precisions better than $0.02 \%, 2 \sigma, \mathrm{n}=7$. Investigations into spectral and non-spectral interferences identified significant formation of $\mathrm{Cr}$ and $\mathrm{Ti}$ oxides and hydroxides ionic species. The analysis of six RMs (BHVO-2 basalt; BCR-2 basalt; AGV-2 andesite; 2709 San Joaquin soil, 1646a estuarine sediment and 1573a tomato leaves) showed good reproducibility $(<0.01 \%$, $2 \sigma, 5 \leq \mathrm{n} \geq 1)$.

Keywords: Analytical geochemistry; Zn isotopes; Isotope geochemistry; Mass spectrometry; Metal isotopes. 


\section{Introduction}

The advent of multi-collector inductively coupled plasma mass spectrometry (MC-ICPMS) promoted the development of new research areas in the isotope geosciences, in particular the stable isotope biogeochemistry of transition metals such as $\mathrm{Cu}, \mathrm{Zn}, \mathrm{Fe}$ and others. $^{1-3}$ Recent studies have shown the great potential of stable metal isotopes to identify contaminant sources, ${ }^{4-5}$ to constrain biogeochemical processes during nutrient cycling, ${ }^{6}$ weathering, ${ }^{7-8}$ and to reconstruct metal transfer processes in complex systems such as the human body. ${ }^{9-10}$ Special attention has been given to $\mathrm{Zn}$ due to its key function as micronutrient in the biosphere and as pollutant in industrial, mining and urban environments. ${ }^{1-3,11}$

The natural variations in the $\mathrm{Zn}$ isotopic composition are small $(<1 \%)$, requiring reliable analytical procedures including chromatographic separation of $\mathrm{Zn}$ from the matrix ${ }^{12-14}$ and accurate correction of the instrumental mass bias. ${ }^{14-16}$ To date, a number of ion exchange chromatographic protocols for specific sample types such as rocks, sediments, marine and fresh water, aerosols, plants and food have been published. ${ }^{17-26}$ Moreover, our understanding about instrumental controls of mass bias including effect of acid strength, dopant/analyte ratios, wet and dry plasma, and matrix has improved. ${ }^{27-32}$ However, the rapid advance of the stable metal isotopes field has not been accompanied by the supply of reference materials (RM), hindering the inter laboratory studies and quality assurances. ${ }^{16}$ For $\mathrm{Zn}$ isotopic compositions, only two certified isotopic reference materials (iCRMs) are available commercially, supplied by the Institute for Reference Materials and Measurements (IRMM-651 and IRMM-3702). ${ }^{16,33}$ These two iCRMs are synthetic solutions that do not matrix match with environmental and geological samples, hence they are not suitable for sample preparation and effect matrix control. ${ }^{16}$

To address this problem, many laboratories have analyzed certified reference materials for elemental concentrations. ${ }^{34}$ To date, the most available $\mathrm{Zn}$ isotopic data have been provided for silicate rocks such as the RMs BHVO-2 basalt, BCR-2 basalt and AGV2 andesite. $^{27}$ Data for RMs with environmental matrices such as soils, plants, and sediments are rarely published, such that only one environmental RM (BCR-281 rye grass) ${ }^{20}$ was reported in a data compilation from different laboratories(see Table 1 in reference 11). 
Thus, improvement of metrological traceability, data quality control and methodological validation for the production of reliable and comparable data on metal isotopes analysis it of the utmost urgency. ${ }^{12,34}$

To address this gap, we set up a method for accurate and precise $\mathrm{Zn}$ isotopic measurements in environmental reference materials in two Brazilian laboratories (Laboratório de Geocrologia at University of Brasília, UnB, and the CPGeo at University of São Paulo, USP). To this end we 1) introduced and calibrated a fast and simple chromatographic separation for $\mathrm{Zn} ; 2$ ) assessed critically mass bias effects related to the analyte-dopant ratios $(\mathrm{Zn} / \mathrm{Cu}) ; 3)$ quantified effects of spectral and non-spectral interferences on $\mathrm{Zn}$ isotopic compositions; and 4) determined new isotopic values for RMs of soils, sediments and plant matrices (2709 San Joaquin soil, 1646a estuarine sediment and $1573 \mathrm{a}$ tomato leaves) extending the data base for $\delta^{66 / 64} \mathrm{Zn}$ in materials relevant for environmental studies. We further expanded the database for previously analyzed RMs like the BHVO-2 basalt, BCR-2 basalt and AGV-2 andesite.

\section{Experimental}

\subsection{Reagents, standards and reference materials}

The work was carried out under clean laboratories conditions in "Class 100" fume hoods, utilizing only Savillex® PFA labware. Ultrapure acids (Merck®) distilled by sub-boiling in Teflon stills, Merck Suprapur $\mathrm{H}_{2} \mathrm{O}_{2}$ (30\%), and de-ionized water (Milli-Q, 18.2 M $\Omega$ ) were used. Multi-element standard solutions (Merck®) were used to produce calibration curves to measure $\mathrm{Cu}, \mathrm{Zn}, \mathrm{Na}, \mathrm{Fe}, \mathrm{Al}, \mathrm{Ca}, \mathrm{Mg}, \mathrm{Ti}, \mathrm{Cr}$ and $\mathrm{K}$ by inductively coupled plasma optical emission spectrometer (ICP OES) and quadrupole inductively coupled plasma mass spectrometry (Q ICP-MS).

The reference materials BHVO-2 basalt (USGS), BCR-2 basalt (USGS) and the AGV-2 andesite (USGS) were used to assess the quantitative recovery of acid dissolution and ion exchange chromatography and the accuracy of the $\mathrm{Zn}$ isotope ratio determinations. The RM 2709 San Joaquin soil (NIST), 1646a estuarine sediment (NIST) and 1573a tomato leaves (NIST) were analyzed to extent the isotope data set for environmental reference materials. The RMs BHVO-2, BCR-2 and AGV-2 were processed and analyzed for comparison with literature data. 


\subsection{Isotopic reference materials and data presentation}

Stable isotopic variations are reported as relative values compared to a reference material and generally expressed in terms of $\delta$-values. ${ }^{1} \mathrm{Zinc}$ has five stable isotopes, ${ }^{64} \mathrm{Zn},{ }^{66} \mathrm{Zn}$, ${ }^{67} \mathrm{Zn},{ }^{68} \mathrm{Zn}$ and ${ }^{70} \mathrm{Zn}$, with average natural abundances of 48.63, 27.90, 4.10, 18.75, and $0.62 \%$, respectively. ${ }^{12}$ The isotope ratio $\mathrm{R}\left({ }^{66} \mathrm{Zn} /{ }^{64} \mathrm{Zn}\right)$ is commonly used because of the highest abundance of the isotopes ${ }^{66} \mathrm{Zn}$ and ${ }^{64} \mathrm{Zn}$. In this work, the $\delta$-values of $\mathrm{Zn}$ isotopic composition are expressed in per mil relative to the Zn standard MERCK (\#9953), henceforward labeled "Zn UnB":

$$
\delta^{66 / 64} Z_{U n B}(\% 0)=\left(\frac{R\left({ }^{66} Z n /{ }^{64} Z n\right)_{\text {sample }}}{R\left({ }^{66} Z n /{ }^{64} Z n\right)}-1\right)(1)
$$

Since common RMs are established as "zero baseline" for isotopic analyses, the results of different laboratories can be compared. ${ }^{11,12}$ To date, the $\delta^{66 / 64} \mathrm{Zn}$ values have been reported in relation to the RM Johnson Matthey® zinc (JMC 3-0749), labeled as $\delta^{66 / 64} \mathrm{Zn}_{\text {JMC. }}{ }^{11,12}$ Since this standard is no longer available, the $\mathrm{Zn}$ isotopic certified reference material from the Institute for Reference Materials and Measurements -IRMM3702 (Zn) have been adopted $\left(\delta^{66 / 64} \mathrm{Zn}_{\mathrm{IRMM}}\right){ }^{27}$ Our $\mathrm{Zn}$ UnB Merck solution was calibrated against Zn JMC 3-0749 and IRMM-3702 to enable comparisons with values of literature.

\subsection{Dissolution of reference materials}

Soils, sediments and rocks reference materials (RMs) were weighed in Savillex ${ }^{\circledR}$ Teflon beakers with sample masses ranging from 20 to $150 \mathrm{mg}$ and digested using a multiplestep acid attack on a hot plate: 1) $1 \mathrm{ml}$ of $14 \mathrm{~mol} \mathrm{~L}^{-1} \mathrm{HNO}_{3}+4 \mathrm{ml}$ of $21 \mathrm{~mol} \mathrm{~L}^{-1} \mathrm{HF}$ for $48 \mathrm{~h}$; drying at $100^{\circ} \mathrm{C}$; 2) $3 \mathrm{ml}$ of $6 \mathrm{~mol} \mathrm{~L}{ }^{-1} \mathrm{HCl}+1 \mathrm{ml}$ of $14 \mathrm{~mol} \mathrm{~L}^{-1} \mathrm{HNO}_{3}$; for $24 \mathrm{~h}$; drying at $100^{\circ} \mathrm{C}$; 3) $1 \mathrm{ml}$ of $6 \mathrm{~mol} \mathrm{~L}^{-1} \mathrm{HCl}+0.5 \mathrm{ml}$ of $14 \mathrm{~mol} \mathrm{~L}^{-1} \mathrm{HNO}_{3}$ for $24 \mathrm{~h}$; drying at $100^{\circ} \mathrm{C}$; 4) $1 \mathrm{ml}$ of $6 \mathrm{~mol} \mathrm{~L}^{-1} \mathrm{HCl}$. Subsequently, the samples were dried again and redissolved in $1 \mathrm{ml}$ of $2 \mathrm{~mol} \mathrm{~L}^{-1} \mathrm{HCl}$ prior to $\mathrm{Zn}$ chromatographic purification (protocol details in the following sections). Blanks and the RMs (BCR-2 or BHVO-2) were included in every sample batch as analytical controls in the elemental analysis. For the plant reference material (1573a tomato leaves, NIST), the digestion was performed using 
microwave digestion (Speedwave 4, Berghof) with an acid mixture of $3 \mathrm{ml}$ of $21 \mathrm{~mol} \mathrm{~L}^{-}$ ${ }^{1} \mathrm{HF}+5 \mathrm{ml}$ of $14 \mathrm{~mol} \mathrm{~L}^{-1} \mathrm{HNO}_{3}+4 \mathrm{ml}$ of $6 \mathrm{~mol} \mathrm{~L}^{-1} \mathrm{HCl}$. After digestion, the solution was transferred to Savillex ${ }^{\circledR}$ Teflon beakers dried on a hot plate at $100^{\circ} \mathrm{C}$, dissolved in 1 $\mathrm{ml}$ of $2 \mathrm{~mol} \mathrm{~L}^{-1} \mathrm{HCl}$, dried again and re-dissolved in $1 \mathrm{ml}$ of $2 \mathrm{~mol} \mathrm{~L}^{-1} \mathrm{HCl}$.

\subsection{Determination of elemental concentration}

Zinc concentrations in the acid dissolutions were determined using ICP OES (Spectroflame FVM03, Spectro Analytical Instrumental GmbH). Zinc in the purified fractions after the chromatographic separation and in the procedural blanks were analyzed using Q ICP-MS (XSeries2, Thermo Scientific). The isotopes ${ }^{66} \mathrm{Zn},{ }^{68} \mathrm{Zn},{ }^{49} \mathrm{Ti},{ }^{47} \mathrm{Ti},{ }^{52} \mathrm{Cr}$, ${ }^{53} \mathrm{Cr},{ }^{56} \mathrm{Fe}$ and ${ }^{57} \mathrm{Fe}$ were analyzed in CCT mode (Collision Cell Technology), and ${ }^{43} \mathrm{Ca}$, ${ }^{43} \mathrm{Ca},{ }^{27} \mathrm{Al},{ }^{24} \mathrm{Mg},{ }^{25} \mathrm{Mg}$ and ${ }^{23} \mathrm{Na}$ were analyzed in the standard mode. The accuracy of concentration determinations in ICP OES and Q ICP-MS was verified with the certified values of the RMs BHVO-2 and BCR-2. The determined elemental concentrations were always within $10 \%$ of the certified values.

2.5 Zinc chromatographic separation: column specifications and development of the elution protocol

The Zinc separation procedure was developed using Poly-prep Bio-Rad chromatography columns with $2 \mathrm{ml}$ of bed volume $(0.8 \times 4 \mathrm{~cm})$ and $9 \mathrm{~cm}$ height, loaded with AG MP1 Bio-Rad macro porous resins (100-200 mesh) and was based on the protocol originally published for the separation of $\mathrm{Zn}, \mathrm{Cu}$ and Fe. ${ }^{12}$ Since $\mathrm{Zn}$ was the only element of interest, the protocol was modified to reduce time; reagents and sample mass (Table 1). In our protocol, the sample is loaded directly in the column with a molarity of $2 \mathrm{~mol} \mathrm{~L}^{-1}$, where $\mathrm{Zn}$ has a high sorptive capacity for the resin AG MP- $1,{ }^{35}$ thus avoiding undesirable loses of $\mathrm{Zn}$ during the matrix elution process. 
Table 1. Original Protocol of Maréchal et al. ${ }^{12}$ and the modified protocol used in this study

\begin{tabular}{|c|c|c|}
\hline \multicolumn{3}{|c|}{ Maréchal et al ${ }^{12}$ protocol } \\
\hline Step & Volume (ml) & Eluent \\
\hline Column conditioning & 6 & $7 \mathrm{~mol} \mathrm{~L}^{-1} \mathrm{HCl}+0.001 \% \mathrm{H}_{2} \mathrm{O}_{2}$ \\
\hline Sample loading & 1 & $7 \mathrm{~mol} \mathrm{~L}^{-1}+0.001 \% \mathrm{H}_{2} \mathrm{O}_{2}$ \\
\hline Matrix elution & 10 & $7 \mathrm{~mol} \mathrm{~L}^{-1}+0.001 \% \mathrm{H}_{2} \mathrm{O}_{2}$ \\
\hline $\mathrm{Cu}$ elution & 20 & $7 \mathrm{~mol} \mathrm{~L}^{-1}+0.001 \% \mathrm{H}_{2} \mathrm{O}_{2}$ \\
\hline Fe elution & 10 & $2 \mathrm{~mol} \mathrm{~L}^{-1} \mathrm{HCl}$ \\
\hline Rinse & 2 & $0.5 \mathrm{~mol} \mathrm{~L}^{-1} \mathrm{HNO}_{3}$ \\
\hline Zn elution & 8 & $0.5 \mathrm{~mol} \mathrm{~L}^{-1} \mathrm{HNO}_{3}$ \\
\hline \multicolumn{3}{|c|}{ Quartz column; high column: $4.3 \mathrm{~cm}$; resin volume: $1.6 \mathrm{ml}$} \\
\hline \multicolumn{3}{|c|}{ Modified Protocol - This study } \\
\hline Step & Volume (ml) & Eluent \\
\hline Column conditioning & 10 & $2 \mathrm{~mol} \mathrm{~L}^{-1} \mathrm{HCl}$ \\
\hline Sample loading & 1 & $2 \mathrm{~mol} \mathrm{~L}^{-1} \mathrm{HCl}$ \\
\hline Matrix elution & 20 & $2 \mathrm{~mol} \mathrm{~L}^{-1} \mathrm{HCl}$ \\
\hline Zn elution & 12 & $0.5 \mathrm{~mol} \mathrm{~L}^{-1} \mathrm{HNO}_{3}$ \\
\hline
\end{tabular}

Biorad $^{\circledR}$ column; height column: $5 \mathrm{~cm}$; resin volume: $2.0 \mathrm{ml}$

The mass of sample loaded on the column was calculated to avoid saturation of exchange sites, since amounts of $\mathrm{Fe}>20 \%$ of theoretical resin saturation can lead to the early elution of light $\mathrm{Zn}$ isotopes and induce its fractionation. ${ }^{13}$ Thus, the content of Fe in each sample was calculated so as not to exceed this value. Considering the theoretical capacity of AG MP1 Bio-Rad resin is $1 \mathrm{meq} / \mathrm{ml}, 2 \mathrm{ml}$ of resin support $4 \times 10^{-4}$ moles or $22.4 \mathrm{mg}$ of Fe. ${ }^{13}$ The resin was cleaned by passing three times $5 \mathrm{ml}$ of $0.5 \mathrm{~mol} \mathrm{~L}^{-1} \mathrm{HNO}_{3}$ and $5 \mathrm{ml}$ of de-ionized water before and after each chromatographic procedure.

\subsection{Assessment of the ion exchange chromatography procedure}

The RMs 1646a Estuarine Sediment (NIST), 1573a Tomato Leaves (NIST), BHVO-2 Basalt (USGS), BCR-2 Basalt (USGS), AGV-2 andesite (USGS) were used to assess the chromatographic separation with respect to recovery, reproducibility and matrix separation efficiency. 
The recovery of $\mathrm{Zn}$ is a critical methodological step for its accurate isotopic determination since the ionic exchange process along the chromatographic column induces isotope fractionation throughout the Zn elution. ${ }^{36}$ The recovery was calculated from the difference between the amount of mass $\mathrm{Zn}$ recovered from purified solution at the end of chromatographic separation and the amount of $\mathrm{Zn}$ initially loaded on the column. The amount of $\mathrm{Zn}$ loaded on the column ( 1 to $3.5 \mu \mathrm{g}$ ) was calculated using the certified values of the elemental standards and RMs. The reproducibility was estimated as the relative standard deviation (RSD) from the $\mathrm{Zn}$ mass recovery of different replicates. In addition, possible chromatographic isotopic fractionation on the column was assessed measuring the $\mathrm{Zn}$ isotopic composition of the $\mathrm{RM} \mathrm{Zn} \mathrm{UnB}$ before and after the ion exchange procedure using the proposed protocol.

Matrix separation efficiency was assessed analyzing the residual matrix elements ( $\mathrm{Ti}, \mathrm{Cr}, \mathrm{Al}, \mathrm{Fe}, \mathrm{Mg}, \mathrm{Ca}$ ) in the $\mathrm{Zn}$ fractions of the RMs after passing through the column. Procedural blanks of the entire analytical protocol including digestion and chromatographic separation were performed during the processing of the sample batches Zinc isotope ratio measurements

Zinc isotopic compositions of sediments sample and reference materials were measured using a ThermoFinnigan Neptune MC-ICP-MS at the Laboratório de Geocronologia of the University of Brasília $(\mathrm{UnB})$ and at the Centro de Pesquisas Geocronológicas (CPGeo) of the University of São Paulo (USP). Both instruments were configured in similar ways using the same inlet system, cones and acid concentrations. The typical operating conditions of the Neptune from both laboratories are shown in the Table 2.

The inlet system consisted of a stable introduction system (SIS) composed by a tandem quartz glass spray chamber (cyclone + standard Scott double pass) coupled with a low flow PFA nebulizer $\left(50 \mu \mathrm{L} \mathrm{min}{ }^{-1}\right)$. The masses $62(\mathrm{Ni}), 63(\mathrm{Cu}), 64(\mathrm{Zn} / \mathrm{Ni}), 65$ $(\mathrm{Cu}), 66(\mathrm{Zn}), 67(\mathrm{Zn})$ and $68(\mathrm{Zn})$ were detected simultaneously using Faraday cups.

The analytical sequences ran automatically using a Cetac ASX-100 autosampler and low mass resolution collector slits, matching $\mathrm{Cu}$ and $\mathrm{Zn}$ concentrations at $300 \mu \mathrm{g} \mathrm{\textrm {L } ^ { - }}$ ${ }^{1}$. Using the standard-sample bracketing technique, each sample was bracketed by a mixed isotopic reference solution ( $\mathrm{Zn} \mathrm{UnB} \mathrm{+} \mathrm{Cu} \mathrm{NIST} \mathrm{SRM} \mathrm{976)} \mathrm{with} \mathrm{rinses} \mathrm{between} \mathrm{sample}$ and standard analyses with $0.05 \mathrm{~mol} \mathrm{~L}^{-1} \mathrm{HNO}_{3}$ from two different vials for 1 minute each. Blank measurements consisted of 1 block of 10 cycles (8s) while samples and the isotopic reference solution were measured in 2 blocks of 20 cycles of 8 s each. For a single 
measurement (40 cycles), internal precision ranged from 3 to $8 \mathrm{ppm}(2 \sigma)$ for both $\mathrm{Cu}$ and Zn. An on-peak baseline correction was applied to correct instrumental and acid blank interference.

The $\mathrm{Zn}$ isotopic determinations of the RM samples were carry out on replicates prepared in separate batches (thus separate digestion and chromatography for each batch). The AGV-2 RM was prepared using a single aliquot.

Table 2. Typical Neptune operating conditions of the USP and UnB laboratories

\begin{tabular}{lcc} 
& CPGeo-USP & Geocronologia-UnB \\
Extraction [V]: & -2000.0 & -1816.3 \\
Focus[V]: & -720.1 & -651.7 \\
Source Quad1[V]: & 248.0 & 248.7 \\
Rot-Quad1[V]: & -6.6 & -2.7 \\
Foc-Quad1[V]: & -19.5 & -19.4 \\
Rot-Quad2[V]: & -0.1 & 28.8 \\
Source Offset[V]: & 20.0 & 0.0 \\
Matsuda Plate[V]: & -1.0 & 0.0 \\
Cool Gas[1/min]: & 16.5 & 15.3 \\
Aux Gas[1/min]: & 0.8 & 0.7 \\
Sample Gas[1/min]: & 1.1 & 1.0 \\
Operation Power[W]: & 1303 & 1263 \\
X-Pos[mm]: & 0.6 & 1.6 \\
Y-Pos[mm]: & -2.6 & -4.8 \\
Z-Pos[mm]: & -3.2 & -7.0 \\
Ampl.-Temp[ $\left.{ }^{\circ} \mathrm{C}\right]:$ & 46.79 & 45.86 \\
Fore Vacuum[mbar]: & $1.61 \times 10^{-3}$ & $1.43 \times 10^{-3}$ \\
High Vacuum[mbar]: & $1.38 \times 10^{-7}$ & $1.12 \times 10^{-7}$ \\
IonGetter-Press[mbar]: & $1.8 \times 10^{-8}$ & $1.31 \times 10^{-8}$ \\
Ni cones & & \\
Low resolution & & \\
\hline
\end{tabular}

\subsection{Instrumental mass bias corrections}

Mass bias (or instrumental fractionation) is a process in which isotopes of the same chemical element are transmitted with different efficiencies by the mass spectrometer resulting in non-uniform sensitivity across the mass range and inaccurate isotope ratio measurements. ${ }^{14,15,29,31,37}$

The simplest technique used to correct mass bias is sample standard bracketing (SSB), which consists of analyzing an unknown sample "bracketed" by standards that are used to interpolate and correct the mass bias drift during data collection. ${ }^{15,31}$ The SSB 
approach assumes that temporal drift in mass bias between bracketing standards is predictable and approximates to a simple mathematical expression (typically a linear interpolation), requiring a stable mass bias over the measurement session there is no significant matrix-induced mass bias. ${ }^{15,29,31}$

Another technique widely applied is the external normalization which consists of doping samples and standard with an element with a known isotope composition and similar fractionation behavior to the element being analyzed (e.g. $\mathrm{Zr}$ doping to Mo isotope analysis, $\mathrm{Mg}$ doping for $\mathrm{Si}$, and $\mathrm{Cu}$ doping for $\mathrm{Zn}$ isotope analysis). ${ }^{15,31,38}$ The measured isotope ratio of the dopant can be compared to its known value to quantify instrumentinduced fractionation (or factor of fractionation $-f$ ) and a correction can then be applied to the isotope ratio of the target element. ${ }^{15,31,38}$ Different mathematical laws are used to associate the true isotopic composition with the measured values and the respective $(f)$ values. For the instrumental fractionation (mass bias) of $\mathrm{Zn}$ and $\mathrm{Cu}$, the exponential law (Equation 2) has been indicated as the most appropriate law to describe it: ${ }^{12}$

$$
R_{\text {meas }}=R_{\text {true }} \cdot\left(\frac{\operatorname{mass}^{i} E}{\text { mass }_{E}}\right)^{f}
$$

where $\operatorname{mass}^{i} E$ and $\operatorname{mass}^{j} E$ represent the masses of the isotopes $i$ and $j$ of the analyteelement E; Rmeas and Rtrue represent the isotopic ratio measured experimentally and the true isotopic ratio of the analyte-element $E$, respectively.

Maréchal and coworkers ${ }^{12}$ demonstrated that $\mathrm{Cu}$ and $\mathrm{Zn}$ isotopes do not fractionate to the same extent but the empirical relationship of $f(\mathrm{Cu}) / f(\mathrm{Zn})$ can be determined plotting the natural logarithm of the raw $\mathrm{Cu}$ and $\mathrm{Zn}$ isotope ratios of standards measured during an analytical session and be used to correct the measured ratios of the analyte element. The corrected $\mathrm{R}\left({ }^{66} \mathrm{Zn} /{ }^{64} \mathrm{Zn}\right)$ ratios for each sample and its bracketing standards are used to calculate the $\delta^{66 / 64} \mathrm{Zn}$ values by $\delta$-equation (equation 1 ). In this work, external normalization was performed by doping samples and bracketing standards with $\mathrm{Cu}$ NIST SRM 976. The certified isotopic value of 0.4456 was used to correct the $\mathrm{Zn}$ isotopic ratios by application of the exponential law. ${ }^{12}$ 


\subsection{Effect of variable analyte-dopant $(\mathrm{Zn} / \mathrm{Cu})$ ratios on $\mathrm{MC}-\mathrm{ICP}-\mathrm{MS}$}

The extent of mass bias is a function of the analyte-dopant $(\mathrm{Zn} / \mathrm{Cu})$ ratio and plasma condition (wet versus dry). ${ }^{19,23}$ Wet plasma conditions show a stronger effect of the $\mathrm{Zn} / \mathrm{Cu}$ ratio compared to the dry plasma (using Aridus I, DSN-100 or Apex HF), likely because of stronger turbulence effects during ionization, vaporization, atomization and excitation. ${ }^{23}$ To this end, we conducted an experiment with sequential analysis of a mixed isotopic reference solution ( $\mathrm{Zn} \mathrm{UnB}+\mathrm{Cu}$ NIST SRM 976) with variable concentration ratios ranging from 1 to 8 . The $\delta$-values were calculated using the SSB and external normalization approaches to compare accuracy and precision for different concentration ratios $(\mathrm{Cu} / \mathrm{Zn})$ and mass bias correction methods. This experiment also allows the identification of the best $\mathrm{Cu} / \mathrm{Zn}$ ratio to be use in the established method and offer a good opportunity to verify similarities and differences between instruments of the same model under different laboratory conditions.

\subsection{Spectral and non-spectral interferences}

Matrix elements induce spectral (isobaric) and non-spectral (matrix effects) interferences, inducing suppression or enhancement of signals, changes on sensitivity and instrumental mass bias, and overlap between the analyte isotopes and other elemental isobars (e.g., ${ }^{64} \mathrm{Ni}$ at ${ }^{64} \mathrm{Zn}$ ), polyatomic ions species such as oxides $(\mathrm{MO})^{+}$and hydroxides $(\mathrm{MOH})^{+}$or double charged ions (e.g., ${ }^{48} \mathrm{Ca}^{2+}$ at $\left.{ }^{24} \mathrm{Mg}\right) .{ }^{19,29,30}$

Even post-chromatographic separation procedures, some residual matrix elements can remain in the purified samples solution, affecting the accurate and precise determinations of $\mathrm{Zn}$ isotope ratios. As demonstrated in previous studies, the $\mathrm{Zn}$ solutions doped with different elements ( $\mathrm{Na}, \mathrm{Fe}, \mathrm{Mg}, \mathrm{Al}, \mathrm{Ti}, \mathrm{V}, \mathrm{Cr}, \mathrm{Ba}$ and $\mathrm{Ce}$ ) showed different magnitudes of interference on the $\mathrm{Zn}$ isotopic ratios, which $\mathrm{Cr}$ and $\mathrm{Ti}$ oxides and hydroxides ions species formed in the plasma were the main isobaric interferences for $\mathrm{Zn}$ isotopes. ${ }^{19,30}$ Other polyatomic species formed in the plasma such $\left({ }^{27} \mathrm{Al}^{40} \mathrm{Ar}^{+}\right)$can cause strong isobaric interference while remaining major elements as $\mathrm{Fe}$ can induce matrix affect $\mathrm{Zn}$ isotope ratio measurements. ${ }^{19,30}$ These studies, however, were carry out on VG Axiom, MicroMass Isoprobe and $\mathrm{Nu}$ Plasma ${ }^{19,30}$ but not on a MC-ICP-MS Neptune instrument. 
In this work, we assessed the potential interferences of $\mathrm{Fe}, \mathrm{Cr}, \mathrm{Al}, \mathrm{Ti}, \mathrm{Mg}, \mathrm{Na}$ and $\mathrm{Ca}$ in a Neptune MC-ICP-MS, doping the isotopic references solution (Cu NIST SRM $976+\mathrm{Zn} \mathrm{UnB}$ ) with these representative matrix elements in the proportion $1: 1$ at concentrations of $300 \mu \mathrm{g} \mathrm{L}^{-1}$. The interference magnitude on $\mathrm{Zn}$ isotope ratios was estimated using the $\delta^{66 / 64} \mathrm{Zn}$ UnB values for the doped reference isotopic solution against the average of the undoped bracketed isotopic reference solution using SSB and external normalization for mass bias correction.

\section{Results and Discussion}

3.1 Assessing the ion exchange chromatographic procedure: recovery, reproducibility, matrix separation and blanks

The experiment of $\mathrm{Zn}$ recovery using replicates of RMs are shown in the Table 3. The chromatographic procedure yielded, on average, recoveries of $99.3 \pm 7.1 \%(\sigma, n=16)$, which falls within the relative error of $\pm 10 \%$ for the certified concentrations values of the CRMs analyzed by ICP OES and Q ICP-MS in our laboratories. Average reproducibility of replicates was c.a. $5 \%$, expressed as percentage of relative standard deviation of the replicates, indicating that the procedure including digestion and chromatographic separation is robust, and confirms quantitative recovery during the separation process. The RMs processed on the column and analyzed by MC-ICP-MS in an intra-run showed $\delta^{66 / 64} \mathrm{Zn}$ values of $0.01 \pm 0.02 \%$ ( 3 replicates, $\sigma, \mathrm{n}=6$ measurements). This uncertainty is well within the reproducibility estimated from repeated measurements of the iCRM Zn IRMM-3702 relative to the RM Zn UnB during several analytical session-days $( \pm 0.03 \%$, $\mathrm{n}=30$, table 5), confirming that the chromatographic column does not induce significant isotopic fractionation on the samples.

The Q ICP-MS scan of all the samples and most of the certified reference materials processed using the ion exchange procedure showed efficient separation of potential interfering elements and $\mathrm{Al} / \mathrm{Zn}, \mathrm{Mg} / \mathrm{Zn}, \mathrm{Ca} / \mathrm{Zn}, \mathrm{Na} / \mathrm{Zn}, \mathrm{Ti} / \mathrm{Zn}$ and $\mathrm{Cr} / \mathrm{Zn}$ ratio were all below $<0.001$. The purified $\mathrm{Zn}$ fractions were free from the main potential interfering metals $\mathrm{Cr}$ and Ti. The reference materials BHVO-2 (basalt) and Estuarine Sediment 1646a had Fe remaining after the chromatographic separation with $\mathrm{Fe} / \mathrm{Zn}$ values corresponding 0.12 and 0.02 respectively. 
The blank contribution of our total procedure including dissolution reagents and chromatography elution was about $44 \pm 14 \mathrm{ng}(\sigma, \mathrm{n}=6)$, which correspond less than $0.1 \%$ of the total $\mathrm{Zn}$ found in samples. This low blank did not require any additional corrections.

Table 3. Zinc recovery yields and reproducibility data obtained for replicates of reference materials.

\begin{tabular}{|c|c|c|c|c|}
\hline Replicates $^{\mathrm{a}}$ & $\begin{array}{l}\mathrm{Zn} \text { mass loaded } \\
(\mu \mathrm{g})\end{array}$ & $\begin{array}{l}\text { Zn recovered } \\
(\mu \mathrm{g})\end{array}$ & $\begin{array}{l}\text { Recovery } \\
(\%)\end{array}$ & $\begin{array}{l}\text { Reproducibility } \\
(\%)^{\mathrm{b}}\end{array}$ \\
\hline Zn UnB - a & 1.0 & 0.95 & 95.0 & 1.5 \\
\hline Zn UnB - a & 1.0 & 0.93 & 93.0 & \\
\hline BHVO-2 basalt- a & 1.0 & 1.08 & 108.0 & 4.9 \\
\hline BHVO-2 basalt- a & 1.0 & 1.01 & 100.8 & \\
\hline BCR-2 basalt $-\mathrm{a}$ & 2.5 & 2.50 & 99.8 & 2.8 \\
\hline BCR-2 basalt $-\mathrm{b}$ & 2.5 & 2.40 & 96.0 & \\
\hline San Joaquin soil - a & 5.0 & 5.15 & 103.0 & 5.4 \\
\hline San Joaquin Soil - b & 5.0 & 4.77 & 95.4 & \\
\hline $1646^{\mathrm{a}}$ Estuarine Sediment- a & 3.5 & 3.65 & 104.2 & 7.0 \\
\hline $1646^{a}$ Estuarine Sediment- b & 3.5 & 3.07 & 87.8 & \\
\hline $1646^{\mathrm{a}}$ Estuarine Sediment- c & 3.5 & 3.36 & 96.0 & \\
\hline $1646^{\mathrm{a}}$ Estuarine Sediment $-\mathrm{d}$ & 3.5 & 3.36 & 96.0 & \\
\hline $1573^{\mathrm{a}}$ Tomate Leaves $-\mathrm{a}$ & 5.0 & 5.28 & 105.6 & 11.4 \\
\hline $1573^{\mathrm{a}}$ Tomate Leaves $-\mathrm{b}$ & 5.0 & 5.88 & 117.6 & \\
\hline $1573^{\mathrm{a}}$ Tomate Leaves $-\mathrm{c}$ & 5.0 & 4.68 & 93.6 & \\
\hline AGV andesite & 1.0 & 0.97 & 97.2 & \\
\hline Average & & & $99.3 \pm 7.1$ & 5.2 \\
\hline
\end{tabular}

\subsection{Determining the optimum analyte-dopant ratio $(\mathrm{Zn} / \mathrm{Cu})$ of isotopic measurements}

The effect of variable $\mathrm{Cu} / \mathrm{Zn}$ ratios on the mass bias was investigated using bi-variant plots of raw $\mathrm{Cu}$ and $\mathrm{Zn}$ isotope ratios (i.e, ratios uncorrected for the mass bias effect) of standards in the ln-ln space (Fig.1). We find consistently straight lines indicating constant instrumental fractionation behavior of $\mathrm{Zn}$ and $\mathrm{Cu}$ confirming invariable $\mathrm{fZn} / \mathrm{fCu}$ over the analytical sessions. The slope ranges between 0.99 and 1.22 for the different $\mathrm{Cu} / \mathrm{Zn}$ ratios, however, demonstrating the mass bias behavior of $\mathrm{Zn}$ and $\mathrm{Cu}$ depend on the analyte/dopant ratio. Our results reinforce the importance of verify empirically the 
relationship between the factor of fractionation of $\mathrm{Zn}(f \mathrm{Zn})$ and $\mathrm{Cu}(f \mathrm{Cu})$ for each analytical season if the SBB is used and highlight the importance of matching dopant $(\mathrm{Cu})$ analyte (Zn) concentrations of samples and standards. ${ }^{23}$

Table 4 shows the $\delta^{66 / 64} \mathrm{Zn}$ values and precision (expressed as $2 \sigma$ of the total number measurements) of the mixed reference isotopic solution ( $\mathrm{Zn} \mathrm{UnB}+\mathrm{Cu}$ NIST SRM 976) analyzed sequentially with different ratios of $\mathrm{Cu} / \mathrm{Zn}$. We find that variable $\mathrm{Cu} / \mathrm{Zn}$ ratios do not have significant effects on accuracy of $\delta^{66} \mathrm{Zn}$ values (all $\delta^{66} \mathrm{Zn}$ values obtained were close to $0.00 \pm 0.01 \%, \sigma, \mathrm{n}=31$ ). However, the analytical precision (or external reproducibility) is affected by the different $\mathrm{Cu} / \mathrm{Zn}$ ratios and hence the mass bias corrections (Table 4). The best external reproducibility $( \pm 0.02 \%, 2 \sigma, n=7)$ was obtained using the $\mathrm{Cu} / \mathrm{Zn}$ ratio of 1 and correcting the ratios by external normalization using the exponential law. The $\mathrm{Cu} / \mathrm{Zn}$ ratio of 1 yielded the best correlation and the slope closest to the theoretical value (0.96) indicating that $f \mathrm{Cu} \approx f \mathrm{Zn}$. Therefore, this experiment shows that the higher the coefficient of determination $\left(\mathrm{R}^{2}\right)$ between the natural logarithms of $\mathrm{Cu}$ and $\mathrm{Zn}$, more precise will be the correction by the external normalization.

Since instrument mass bias behavior can change day to day, a plot of the measurements of the mixed reference isotopic solution ( $\mathrm{Zn} \mathrm{UnB} \mathrm{+} \mathrm{Cu} \mathrm{NIST} \mathrm{SRM} \mathrm{976)}$ analyzed on consecutive days $(n=121)$ are presented in Fig.2. The results showed that the $\mathrm{Cu} / \mathrm{Zn}$ ration of 1 maintains the slope of the mass bias line close to 1.0 and a good correlation coefficient on both instruments. Throughout this study, the largest extent of mass bias was observed in the Neptune-at UnB (Fig.2).

Summarizing our recent results using different $\mathrm{Cu} / \mathrm{Zn}$ ratios, the use of $\mathrm{Cu}$-doping in the proportion of $1: 1$ with $\mathrm{Zn}$ (at concentrations of $300 \mu \mathrm{g} \mathrm{L}^{-1}$ ) provided the more constant mass bias and consequently more precise results using the external normalization. Thus, the ratio $\mathrm{Cu} / \mathrm{Zn}$ ration of 1 was applied to all samples and isotopic reference solution measured in this study. 
Table 4. Accuracy and reproducibility for the isotopic reference solution (Zn UnB + Cu NIST SRM 976) using different methods of mass bias correction and different $\mathrm{Cu} / \mathrm{Zn}$ concentration ratios.

\begin{tabular}{|c|c|c|c|c|c|}
\hline & \multirow{2}{*}{$\begin{array}{c}\delta^{66 / 64} \mathrm{Zn}_{\mathrm{UnB}} \mathrm{SSB} \\
\text { average }\end{array}$} & \multicolumn{3}{|c|}{$\delta^{66 / 64} \mathrm{Zn}_{\mathrm{UnB}} \mathrm{Ext}$} & \multirow[t]{2}{*}{$n^{*}$} \\
\hline & & $2 \sigma$ & average & $2 \sigma$ & \\
\hline $\mathrm{Cu} / \mathrm{Zn}=1$ & 0.01 & 0.07 & 0.00 & 0.02 & 7 \\
\hline $\mathrm{Cu} / \mathrm{Zn}=2$ & -0.01 & 0.17 & -0.01 & 0.11 & 6 \\
\hline $\mathrm{Cu} / \mathrm{Zn}=4$ & 0.00 & 0.05 & 0.00 & 0.05 & 6 \\
\hline $\mathrm{Cu} / \mathrm{Zn}=8$ & 0.00 & 0.06 & 0.00 & 0.08 & 12 \\
\hline
\end{tabular}

$n^{*}:$ number of measurements

SSB: sample standard bracketing.

Ext: external normalization applying the exponential law.

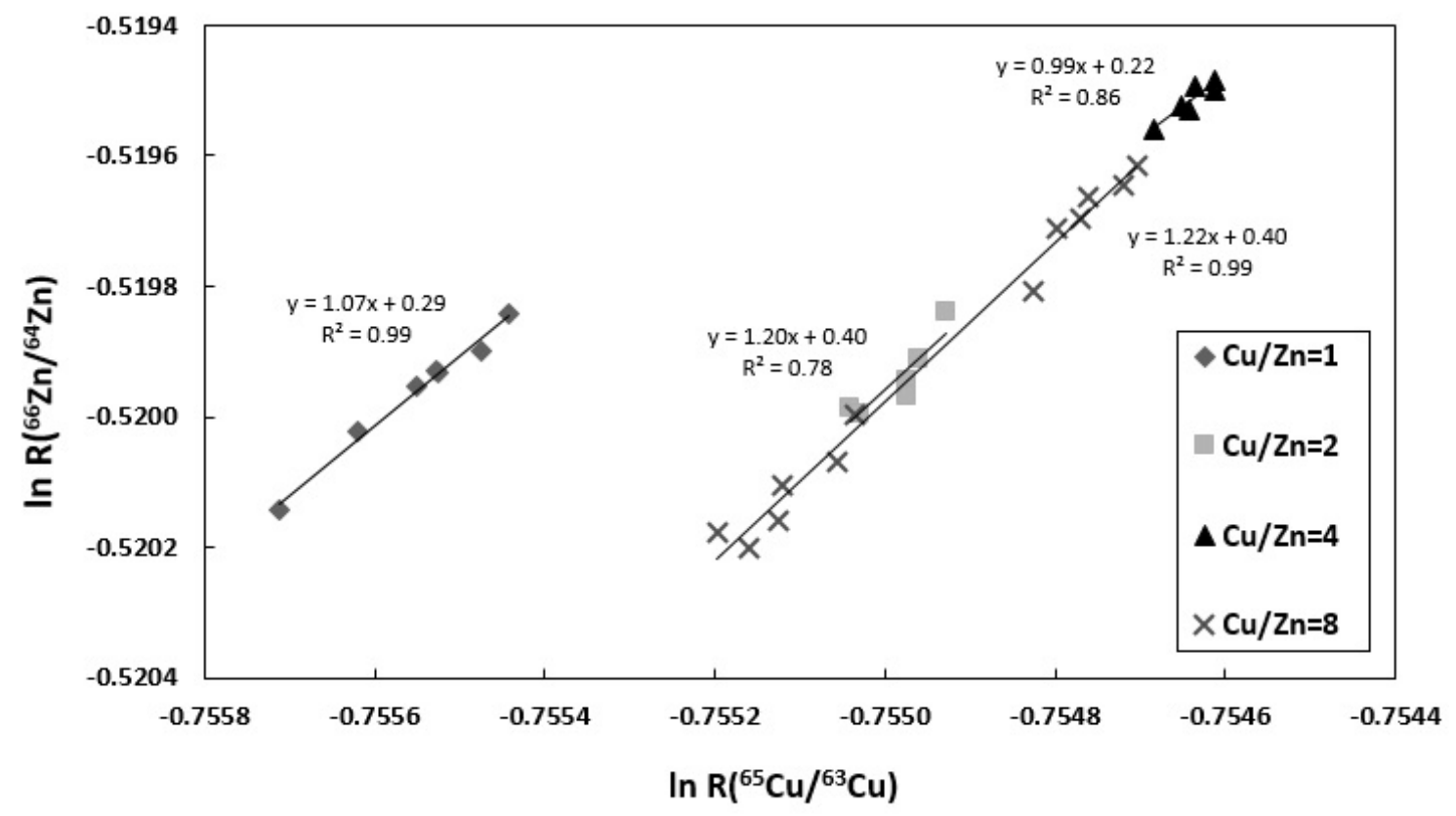

Fig.1. The effect of variable $\mathrm{Cu} / \mathrm{Zn}$ ratios performed on the Neptune USP using the mixed reference isotopic solution ( $\mathrm{Zn} \mathrm{UnB}+\mathrm{Cu}$ NIST SRM 976). The $\mathrm{Cu} / \mathrm{Zn}$ ration of 1 showed the closest slope to the theoretical value $(\approx 0.96)$ and the best coefficient of determination $\left(\mathrm{R}^{2}=0.99\right)$. 


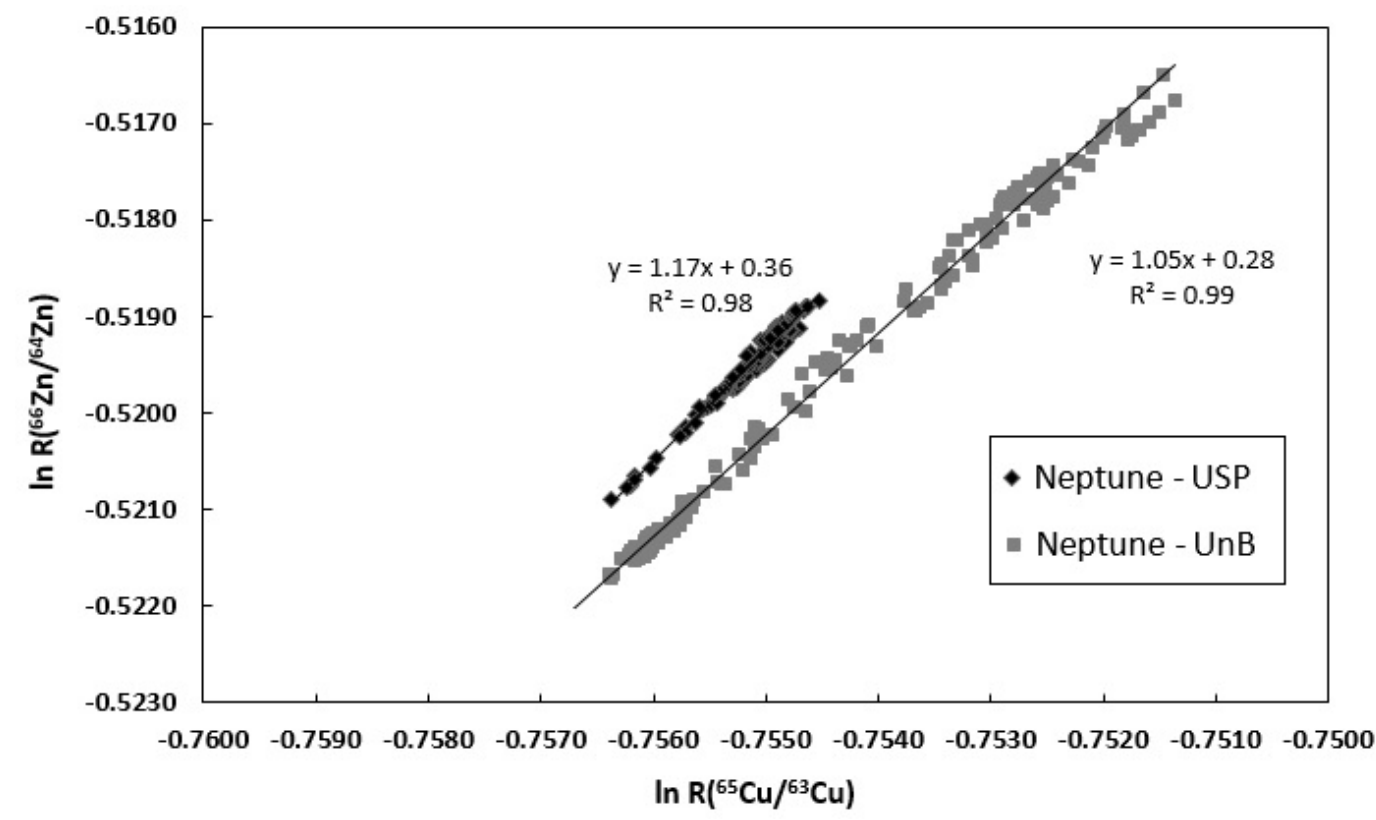

Fig.2. Plot of $\ln \mathrm{R}\left({ }^{66} \mathrm{Zn} /{ }^{64} \mathrm{Zn}\right)$ versus $\ln \mathrm{R}\left({ }^{65} \mathrm{Cu} /{ }^{63} \mathrm{Cu}\right)$ for 121 measurements of the isotopic solution ( $\mathrm{Zn} \mathrm{UnB}+\mathrm{Ni}$ NIST 986) over several analytical sessions on consecutive days using the Neptunes of USP and UnB universities over a year. The slopes of the mass bias lines obtained in both instruments (1.17 at USP and 1.05 at $\mathrm{UnB})$ is close to the theoretical value $(\approx 0.96)$ indicating that $f C u \approx f Z n$. Moreover, both instruments maintained good correlations between the $\mathrm{Cu}$ and $\mathrm{Zn}$ isotopic ratios. In general, the Neptune-UnB showed large mass bias drift over time.

\subsection{Assessing spectral and non-spectral interferences effects on Zn isotopic ratios}

The doped isotopic reference solution ( $\mathrm{Zn} \mathrm{UnB}+\mathrm{Cu}$ NIST SRM 976) with matrix elements, i.e, $\mathrm{Fe}, \mathrm{Cr}, \mathrm{Al}, \mathrm{Ti}, \mathrm{Mg}$, and $\mathrm{Ca}$ showed a strong effect on the accuracy of the $\delta^{66 / 64} \mathrm{Zn}$ values (Fig.3). Chromium and titanium induced shifts higher than $0.1 \%$ due to the isobaric oxides and hydroxide ionic species $\left({ }^{48} \mathrm{Ti}^{16} \mathrm{O}\right)^{+},\left({ }^{48} \mathrm{Ti}^{16} \mathrm{OH}\right)^{+},\left({ }^{52} \mathrm{Cr}{ }^{16} \mathrm{O}\right)^{+}$, $\left({ }^{52} \mathrm{Cr}^{16} \mathrm{O}^{1} \mathrm{H}\right)^{+}$, while $\mathrm{Fe}, \mathrm{Al}, \mathrm{Ca}, \mathrm{Mg}$ inducing lower shifts $(<0.1 \%)$. This pattern was observed in previous studies ${ }^{19,30}$ and suggests that inlet systems and ICPs from different MC-ICP-MS models do not differ with respect to the production of interferences when operating in wet plasma. Mason et al. ${ }^{30}$ found little differences in the formation and/or persistence of matrix related polyatomic species in the VG Axiom or the Isoprobe instruments. Our data suggests that the MC-ICP-MS Neptune instrument operated in the wet mode is affected in a similar way to other instruments.

Comparing the isotopic compositions by the different mass bias correction approaches, the external normalization method improved precision compared to the SSB method. This demonstrates that external normalization is capable of attenuating (but not 
totally) the matrix effects, reinforcing the importance of chemical separation quality prior the chromatography. As demonstrated by Mason et al. ${ }^{30}$ and Petit et al. ${ }^{22}$, the reduction of oxide and hydroxide ionic species using dry plasma or a second passage through the column are the best alternatives in case of remaining matrix elements on the sample solution. ${ }^{39}$

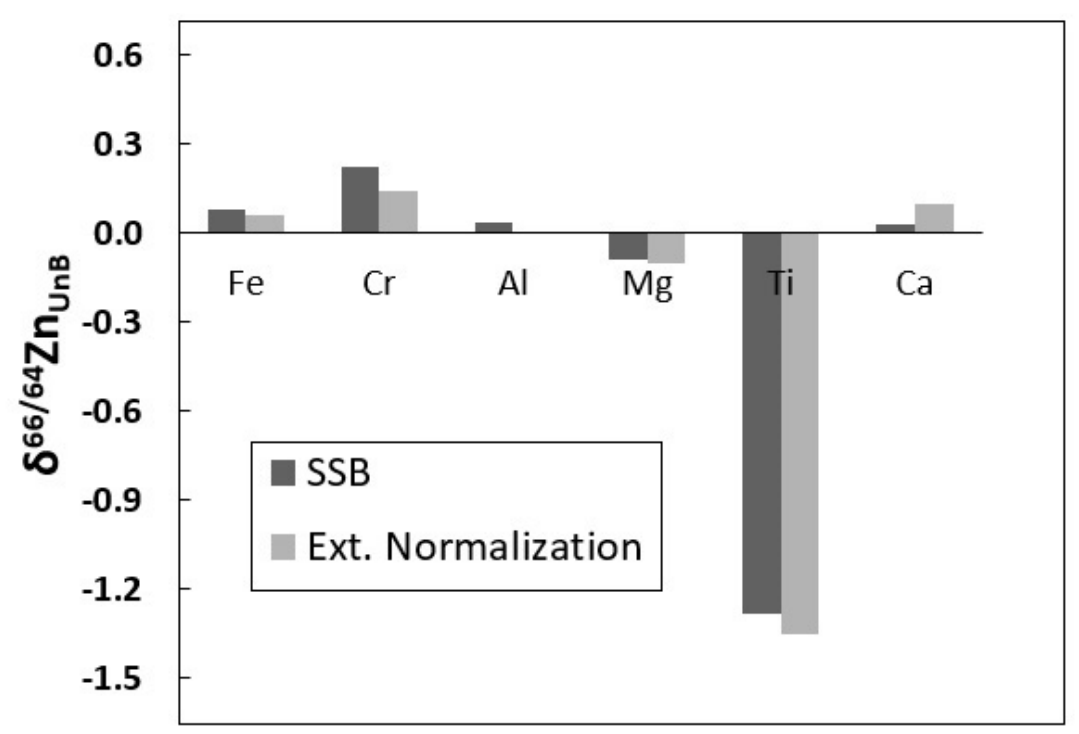

Fig.3. Interference assessed for different elements of the $\mathrm{Zn}$ isotopic compositions. The $\delta$-values of doped mixed reference isotopic solution ( $\mathrm{Zn} \mathrm{UnB}$ + $\mathrm{Cu}$ NIST SRM 976) were calculated against the undoped bracketed mixed reference solution using the sample standard bracketing (SSB) and external normalization (Ext) corrections.

\subsection{Zn isotopic compositions of environmental RMs}

The RM Zn UnB was calibrated against the iCRM Zn IRMM 3702 and the RM Zn JMC 3-0749 during several analytical session. The instrumental settings and analytical procedures were the same applied to the samples, using the external normalization for mass bias corrections, $\mathrm{Cu}$-dopant and $\mathrm{Zn}$-analyte matched at concentrations of $300 \mu \mathrm{g} \mathrm{L}^{-}$ ${ }^{1}$ and the RM Zn UnB as a bracketed standard. The results are presented in Table 5 and the conversion of the $\delta^{66} \mathrm{Zn}_{\text {UnB }}$ values to $\delta^{66 / 64} \mathrm{Zn}_{\text {IRMM }}$ and $\delta^{66 / 64} \mathrm{Zn}_{\text {JMC }}$ values is obtained applying the following equations:

$$
\begin{aligned}
& \delta^{66 / 64} \mathrm{Zn}_{\text {UnB }}=\delta^{66 / 64} \mathrm{Zn}_{\text {IRMM }}+0.13 \% \\
& \delta^{66 / 64} \mathrm{Zn}_{\text {UnB }}=\delta^{66 / 64} \mathrm{Zn}_{\mathrm{JMC}}-0.14 \%
\end{aligned}
$$


The $\delta^{66 / 64} \mathrm{Zn}_{\mathrm{UnB}}$ and $\delta^{66 / 64} \mathrm{Zn}_{\text {JMC-3-0749L }}$ determined for the iCRM Zn IRMM 3702 are

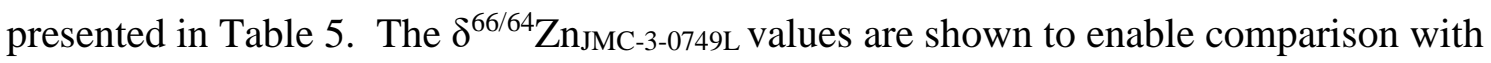
the literature since the $\delta^{66 / 64} \mathrm{Zn}_{\mathrm{JMC}}$ continues to be the more widely reported reference standard. Error propagations were used to calculate the error of $\delta^{66 / 64} \mathrm{Zn}_{\text {JMC }}$ values

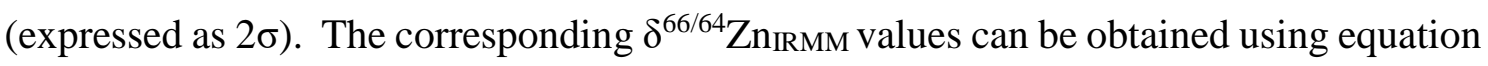
3.

The external reproducibility $(2 \sigma)$ for replicate measurements ( $n=2$ to 5 ) of $R M$ with environmental matrices are below 0.1\%o (Table 5). For the synthetic RMs Zn UnB and Zn JMC 3-0749, the reproducibility calculated from 34 measurements in different analytical sessions were 0.08 and $0.06 \%$, respectively.

The RMs BHVO-2 and BCR-2 were used to test critically the analytical accuracy of our analytical procedures as it allows comparison with previously published data (Table 5), while the RMs 2709 San Joaquin soil, 1646a estuarine sediment and 1573a tomato leaves are reported to enable future quality controls of $\mathrm{Zn}$ isotope ratio measurements related to environmental studies. The results of our BHVO-2 and BCR-2 $\left(\delta^{66 / 64} \mathrm{ZnJMC}=+0.25 \pm 0.09\right.$ and $+0.25 \pm 0.10 \%$, $2 \sigma$, respectively $)$ are in line with previously published values (Table 5) ranging between +0.2 and $+0.3 \%$ associated to igneous rocks. ${ }^{40}$ The $\delta^{66 / 64} \mathrm{Zn}_{\mathrm{JMC}}$ value for 1646 a estuarine sediment $(+0.32 \pm 0.07 \%$ o, $2 \sigma$, $\mathrm{n}=8)$ is close to typical values for igneous rocks, marine sediments and sapropels $(0.23$ $\pm 0.08 \%$ o $2 \sigma, \mathrm{n}=20 ; 0.28 \pm 0.02 \%, 2 \sigma, \mathrm{n}=3$, respectively). ${ }^{41}$

The $\delta^{66 / 64} \mathrm{Zn}_{\mathrm{JMC}}$ value for the 2709 San Joaquin soil is $0.28 \pm 0.09 \%$ which is close to the $\delta^{66 / 64} \mathrm{Zn}_{\text {JMC }}$ of $0.2 \%$ suggested for unpolluted soils. ${ }^{42}$ The $\delta^{66 / 64} \mathrm{Zn}_{\text {JMC values of }}$ $0.79 \pm 0.09 \%$ o $(2 \sigma, n=8)$ for 1573 a tomato is within the large range found in the plant leaves ranging from -0.91 to $0.63 \%$ for herbaceous species and $0.98 \pm 0.19 \%$, $2 \sigma$ for bamboo leaves. ${ }^{7,43}$ The several factors of fractionation such as diffusive processes in cross-cell membrane transport, $\mathrm{Zn}$ bioavailable speciation, and rhizosphere reactions ${ }^{44,45}$ probably is associated to this heavy isotopic compositions of $1573 \mathrm{a}$ tomato leaves compared with soils and sediments. 
Table 5. Results of Zinc isotope determinations of Reference Isotopic Standards and Reference Materials.

\begin{tabular}{|c|c|c|c|c|}
\hline $\begin{array}{c}\text { Isotopic Standard/ } \\
\text { RMs }\end{array}$ & Reference & $\delta^{66 / 64} \mathrm{Zn} \mathrm{JMC}$ & $\delta^{66 / 64} \mathrm{Zn} \mathrm{UnB}$ & $\begin{array}{c}n \\
\text { (Replicates) }^{b}\end{array}$ \\
\hline \multirow[t]{2}{*}{ IRMM-3702 } & This study & $-0.27 \pm 0.07$ & $+0.13 \pm 0.03$ & $30(1)$ \\
\hline & Moeller et al. ${ }^{27}$ & $-0.30 \pm 0.05^{\mathrm{a}}$ & & \\
\hline \multirow[t]{5}{*}{$\begin{array}{c}\text { BHVO-2 } \\
\text { Basalt }\end{array}$} & This study & $0.25 \pm 0.09$ & $0.08 \pm 0.08$ & $10(5)$ \\
\hline & Herzog et al. ${ }^{46}$ & $0.29 \pm 0.09$ & & \\
\hline & Moynier et al. ${ }^{47}$ & $0.21 \pm 0.09$ & & \\
\hline & Moeller et al. ${ }^{27}$ & $0.48 \pm 0.13$ & & 3 \\
\hline & Chen et al. ${ }^{41}$ & $0.33 \pm 0.04$ & & \\
\hline \multirow[t]{7}{*}{$\begin{array}{l}\text { BCR-2 } \\
\text { Basalt }\end{array}$} & This study & $0.25 \pm 0.08$ & $0.08 \pm 0.06$ & $10(5)$ \\
\hline & Archer and Vance 32 & $0.20 \pm 0.09$ & & 12 \\
\hline & Chapaman et al. ${ }^{13}$ & $0.29 \pm 0.12$ & & 8 \\
\hline & Cloquet et al. $^{12}$ & $0.32 \pm 0.13$ & & 2 \\
\hline & Sonke et al. ${ }^{5}$ & $0.25 \pm 0.04$ & & 4 \\
\hline & Herzog et al. ${ }^{46}$ & $0.33 \pm 0.09$ & & \\
\hline & Moeller et al. ${ }^{27}$ & $0.33 \pm 0.13$ & & 3 \\
\hline \multirow[t]{3}{*}{$\begin{array}{c}\text { AGV-2 } \\
\text { Andesite }\end{array}$} & This study & $0.29 \pm 0.06$ & $0.12 \pm 0.03$ & $2(1)$ \\
\hline & Moynier et al. ${ }^{47}$ & $0.25 \pm 0.09$ & & \\
\hline & Chen et al. ${ }^{41}$ & $0.32 \pm 0.04$ & & \\
\hline $\begin{array}{c}\text { 2709 San Joaquin } \\
\text { Soil }\end{array}$ & This study & $0.28 \pm 0.10$ & $0.11 \pm 0.09$ & $4(2)$ \\
\hline $\begin{array}{c}\text { 1646a Sediment } \\
\text { Estuarine }\end{array}$ & This study & $0.32 \pm 0.06$ & $0.15 \pm 0.04$ & $4(2)$ \\
\hline $\begin{array}{c}\text { 1573a } \\
\text { Tomate Leaves }\end{array}$ & This study & $0.79 \pm 0.09$ & $0.62 \pm 0.07$ & $4(2)$ \\
\hline
\end{tabular}

a-The value reported represent the average of the values published in the literature. ${ }^{11,14,19}$

b- For the standards and reference materials analyzed in this study, the number of replicates are indicated in the parentheses. Each replicate was prepared separately with different digestions and chromatographic separation for the determination of the $\mathrm{Zn}$ isotopic compositions. 


\section{Conclusion}

A procedure for determining the $\mathrm{Zn}$ isotopic compositions in environmental samples has been developed through the co-operation between two Brazilian laboratories. The method focused on establishing of a simple and fast chromatographic separation of $\mathrm{Zn}$ isotopes from complexes environmental matrices (soils, sediments, rocks and plants), on instrumental controls of mass bias and matrix interferences and on the determinations of $\mathrm{Zn}$ isotopic compositions in reference materials from NIST and USGS.

The chromatographic column calibration experiments showed a fit-for-purpose matrix separation, reproducibility $(<0.01 \%, 5 \leq \mathrm{n} \geq 1,2 \sigma)$ and practically $100 \%$ recoveries yields. During analysis sessions, both laboratories instruments (ThermoFinnigan Neptune) presented similar mass bias behavior with $f \mathrm{Zn} \approx f \mathrm{Cu}$. External normalization using Cu NIST SRM 976 with the dopant/analyte ration $(\mathrm{Cu} / \mathrm{Zn})$ of 1 produced more precise results than Standard Sample Bracketing (SSB) for the mass bias corrections. Investigations on spectral and non-spectral interferences in matrix-doped standards identified the formation of $\mathrm{Cr}$ and $\mathrm{Ti}$ oxides and hydroxides ionic species in the plasma as the main interferences on $\mathrm{Zn}$ isotopes ratios. Other elements such $\mathrm{Fe}, \mathrm{Ca}, \mathrm{Mg}$ do not produce large interferes, with shifts commonly lower than $0.1 \%$.

Six certified reference materials (USGS and NIST materials) were analyzed: BHVO-2 basalt; BCR-2 basalt; AGV-2 andesite; San Joaquin Soil SRM 2709, 1646a Estuarine Sediment and 1573a tomato leaves. In the case of rock RMs (BHVO-2 basalt; BCR-2 basalt; AGV-2 andesite) the $\delta^{66 / 64} \mathrm{Zn}_{\mathrm{JMC}}$ values were in agreement with the values reported in the literature.

This work contributed with a simplified chromatographic protocol for $\mathrm{Zn}$ separation, additional insights about the mass bias processes in the MC-ICP-MS instruments and a new dataset of $\mathrm{Zn}$ isotopic compositions for environmental reference materials in order to fill a gap in the metrological traceability and analytical control of $\mathrm{Zn}$ isotopic data, and stimulate future inter-laboratorial calibrations.

\section{Acknowledgements}

CAPES and CNPq provided the scholarships that supported this work of Daniel Araújo. We thank all the laboratory personnel of the Institute of Geociences at UnB and USP, especially, Erico Zacchi, Myller Tonhá, Fernando Cavalcante and Jeane Chaves for their 
collaboration in this study. Timothy Mulholland is thanked for his substantial support on English grammar correction. We thank the two anonymous reviewers for their valuable suggestions and comments.

\section{References}

1. Wiederhold, J.; Environ. Sci. Technol. 2015, 49, 2606.

2. Bullen, T. In Handbook of Environmental Isotope Geochemistry; Baskaran, M., ed.; Springer: Heidelberg, Germany, 2011.

3. Weiss, D.; Rehkdmper, M.; Schoenberg, R.; McLaughlin, M.; Kirby, J.; Campbell, P.; Arnold, T.; Chapman, J.; Peel, K.; Gioia, S.; Environ. Sci. Technol. 2008, 42, 655.

4. Yin, N.; Sivry, Y.; Benedetti, M.; Lens, P.; van Hullebusch, E.; Appl. Geochem. 2016, 64, 128.

5. Sonke, J.; Sivry, Y.; Viers, J.; Freydier, R.; Dejonghe, L.; Andre, L.; Aggarwal, J.; Fontan, F.; Dupre, B.; Chem. Geol. 2008, 252, 145.

6. Peel, K.; Weiss, D.; Siggc, L.;Limnol. Oceanogr. 2009, 54, 1699.

7. Viers, J.; Oliva, P.; Nonell, A.; Gelabert, A.; Sonke, J.; Freydier, R.; Gainville, R.; Dupre, B.; Chem. Geol. 2007, 239, 124.

8. Mulholland, D.; Poitrasson, F.; Boaventura, G.; Allard, T.; Vieira, L.; Santos, R.; Mancini, L.; Seyler, P.; Geochim. Cosmochim. Ac. 2015, 150, 142.

9. Jaouen, K.; Pons, M.; Balter, V.; Earth Planet. Sc. Lett. 2013, 374, 164.

10.Larner, F.; Woodley, L.; Shousha, S.; Moyes, A.; Humphreys-Williams, E.; Strekopytov, S.; Halliday, A.; Rehkämper, M.; Coombes, R.; Metallomics 2015, 7, 112.

11. Cloquet, C.; Carignan, J.; Lehmann, M.; Vanhaecke, F.; Anal Bioanal Chem 2008, 392, 451.

12. Maréchal, C.; Télouk, P.; Albaréde, F.; Chem. Geol. 1999, 156, 251.

13. Chapman, J.; Mason, T.; Weiss, D.; Coles, B.; Wilkinson, J.; Geostand. Geoanal. Res.2006, 30, 5.

14. 7.Sossi, P.; Halverson, G.; Nebel, O.; Eggins, S. ;Geostandards and Geoanalytical Research 2014, 39.

15. Peel, K.; Weiss, D.; Chapman, J.; Arnold, T.; Coles, B.; J. Anal. At. Spectrom. 2008, 23, 103.

16. Irrgeher, J.; Prohaska, T. ;Anal Bioanal Chem, 2015, 408:369-385.

17. Sivry, Y.; Riotte, J.; Sonke, J.; Audry, S.; Schafer, J.; Viers, J.; Blanc, G.; Freydier, R.; 
Dupre, B.; Chem. Geol. 2008, 255, 295.

18. Thapalia, A.; Borrok, D.; Van Metre, P.; Musgrove, M.; Landa, E.; Environ. Sci. Technol. 2010, 44, 1544.

19. Petit, J.; de Jong, J.; Chou, L.; Mattielli, N.; Geostand. Geoanal. Res.2008, 32, 149.

20. Weiss, D.; Rausch, N.; Mason, T.; Coles, B.; Wilkinson, J.; Ukonmaanaho, L.; Arnold, T.; Nieminen, T.; Geochim. Cosmochim. Ac.2007, 71, 3498.

21. Conway, T.; Rosenberg, A.; Adkins, J.; John, S.; Anal. Chim. Acta 2013, 793, 44.

22. Chen, J.; Gaillardet, J.; Louvat, P.; Huon, S.; Geochim. Cosmochim. Ac.2009, 73, 4060.

23. Chen, J.; Louvat, P.; Gaillardet, J.; Birck, J.; Chem. Geol. 2009, 259, 120.

24. Gioia, S.; Weiss, D.; Coles, B.; Arnold, T.; Babinski, M.; Anal. Chem.2008, 80, 9776.

25. Arnold, T.; Schönbächler, M.; Rehkämper, M.; Dong, S.; Zhao, F.; Kirk, G.; Coles, B.;

Weiss, D.; Anal Bioanal Chem 2010, 398, 3115.

26.Costas-Rodríguez, M.; Van Heghe, L.; Vanhaecke, F. ;Metallomics 2014, 6.

27. Moeller, K.; Schoenberg, R.; Pedersen, R.; Weiss, D.; Dong, S.; Geostand. Geoanal. Res.2012, 36, 177.

28. Zhu, Z.; Jiang, S.; Yang, T.; Wei, H.; Int. J. Mass. Spectrom. 2015, 393, 34.

29. Albarède, F.; Beard, B. In Geochemistry of Non-Traditional Stable Isotopes. Johson, C.M; Beard, B.; Albarède, F, eds.; Mineralogical Society of America: Washigton, United States of America, 2004.

30. Mason, T.; Weiss, D.; Horstwood, M.; Parrish, R.; Russell, S.; Mullane, E.; Coles, B.; J. Anal. Atom. Spectrom. 2004, 19, 209.

31. Mason, T.; Weiss, D.; Horstwood, M.; Parrish, R.; Russell, S.; Mullane, E.; Coles, B.; J. Anal. Atom. Spectrom. 2004, 19, 218.

32. Archer, C.; Vance, D.; J. Anal. Atom. Spectrom. 2004, 19, 656.

33. Vogl J, Pritzkow W; Reference materials in isotopic analysis. In: Isotopic analysis. WileyVCH Verlag GmbH \& Co. KGaA, pp 139-163. 2012.

34. de Laeter JR; Geostand Geoanal Res, 2005, 29(1):53-61.

35. Kraus, K.; Moore, G.; J. Am. Chem. Soc. 1953, 75, 1460.

36.Maréchal, C.; Albarède, F. ;Geochimica et Cosmochimica Acta 2002, 66(9): 1499-1509.

37. Heumann, G. K.; Gallus, M. S.; Rädlinger, G.; Vogl, J.; J. Anal. Atom. Spectrom. 1998, 13,1001 .

38. Longerich, H.; Fryer, B.; Strong, D.; Spectrochim. Acta B. 1987, 42, 39.

39. Dong, S.; Weiss, D.; Strekopytov, S.; Kreissig, K.; Sun, Y.; Baker, A.; Formenti, P. ;Talanta 2013, 114. 
40. Chen, H.; Savage, P.; Teng, F.; Helz, R.; Moynier, F.; Earth Planet. Sc. Lett. 2013, 369, 34.

41. Maréchal, C.; Nicolas, E.; Douchet, C.; Albarède, F.; Geochemistry Geophys. Geosystems 2000, 1 .

42.Fekiacova, Z.; Cornu, S.; Pichat, S.; Sci. Total. Environ. 2015, 517, 96.

43. Moynier, F.; Pichat, S.; Pons, M.; Fike, D.; Balter, V.; Albarède, F.; Chem. Geol 2009, 267, 125 .

44. Jouvin, D.; Weiss, D.; Mason, T.; Bravin, M.; Louvat, P.; Zhao, F.; Ferec, F.; Hinsinger, P.; Benedetti, M.; Environ. Sci. Technol. 2012, 46, 2652.

45. Coutaud, A.; Meheut, M.; Viers, J.; Rols, J.; Pokrovsky, O.; Chem. Geol. 2014, 390, 46.

46.Herzog, G.; Moynier, F.; Albarède, F.; Berezhnoy, A. ;Geochimica et Cosmochimica Acta 2009, 73.

47.Moynier, F.; Beck, P.; Yin, Q.; Ferroir, T.; Barrat, J.; Paniello, R.; Telouk, P.; Gillet, P. ;Chemical Geology 2010, 276. 


\section{Chapter 5}

\section{ZINC ISOTOPES AS TRACERS OF WASTE FROM ELECTROPLATING INDUSTRIES IN COASTAL ENVIRONMENTS}

(manuscript summited to Chemical Geology Journal and accepted with corrections)

Daniel F. Araújo ${ }^{\mathrm{a}-\mathrm{b}-1}$; Geraldo R. Boaventura ${ }^{\mathrm{a}}$; Wilson Machado ${ }^{\mathrm{c}}$; Jerome Viers ${ }^{\mathrm{b}}$; Dominik Weiss ${ }^{\mathrm{d}}$; Sambasiva R. Patchineelamc; Izabel Ruiz ; Ana Paula C. Rodrigues ${ }^{\mathrm{c}}$; Marly Babinski ${ }^{\mathrm{e} ;}$ Elton Dantas ${ }^{\mathrm{a} ;}$

a. Universidade de Brasília, Instituto de Geociências, Campus Darcy Ribeiro, L2, Asa Norte, Brasília, Distrito Federal, Brazil.

b. Géosciences Environnement Toulouse (GET-UMR 5563 CNRS, Université Paul Sabatier, IRD), 14 Edouard Belin, 31400, Toulouse, France.

c. Universidade Federal Fluminense, Departamento de Geoquímica, Campus do Valonguinho, Niterói, Rio de Janeiro, Brazil.

d. Imperial College London, Earth Science and Engineering, London, United Kingdom

e. Universidade de São Paulo, Instituto de Geociências, Rua do Lago 562, Cidade Universitária, São Paulo, Brazil.

1-Corresponding author: Daniel F. Araújo: danielunb.ferreira@gmail.com, phone: +5561983080712 


\section{Abstract}

The legitimacy of $\mathrm{Zn}$ isotopes to trace anthropogenic sources in coastal areas has been tested in this study. We determined the stable isotopic composition of $\mathrm{Zn}$ of five sediment cores, surface sediment samples, suspended particulate matter (SPM), leaves of mangrove trees and rocks collected at the Sepetiba Bay, an estuarine-lagoon impacted by an industrialized coastal area near Rio de Janeiro, Brazil, as well as in ore samples. The aim was to test if this tracer system enables i) to identify sources and sinks of anthropogenic $\mathrm{Zn}$; ii) to reconstruct the temporal and spatial evolution of $\mathrm{Zn}$ contamination; iii) to verify the influence of estuarine biogeochemical processes on the $\mathrm{Zn}$ isotopic signature during the element transport and deposition and iv) to investigate the effects of anthropogenic contamination on the $\mathrm{Zn}$ isotopes signature of mangrove leaves. Zinc contents in the more contaminated sampling site reached levels up to $4 \%$ of sediment dry weight. The zinc isotopic compositions (expressed using the $\delta^{66} \mathrm{Zn}$ notation relative to the JMC 3-0749-L solution) showed significant variations in the sediment cores, the SPM, leaves and willemite ore minerals ranging between -0.01 and $+1.15 \%$. Sediment cores showed high correlation between $\delta^{66} \mathrm{Zn}$ and $\mathrm{Zn}$ enrichment factors, suggesting good preservation of the isotopic record. The $\mathrm{Zn}$ isotopic composition of leaves is lighter than in the contaminated sediments confirming isotopic fractionation occurring during plant uptake. The sediments and SPM samples collected close to old metallurgic area have the highest $\mathrm{Zn}$ concentrations and the heaviest isotopic compositions. The $\delta^{66} \mathrm{Zn}_{\mathrm{JMC}}$ signature for metallurgical wastes was estimated to $+0.86 \pm 0.15 \%$ o $(2 \sigma)$, which is heavier than the values observed for willemite (ranging from -0.1 to $0.14 \%$ ). This suggests a significant fractionation induced by electroplating processes. The sediment core sampled from a mangrove located close to the metallurgical wastes source preserved the isotopic signatures of this source in most layers. However, there is evidence that biogeochemical processes triggered by hydrodynamics, bioturbation and rhizosphere processes slightly changed the isotopic signatures in some layers from this core toward heavier $\delta^{66} \mathrm{Zn}_{\mathrm{JMC}}$ values above $+1.0 \%$. The $\delta^{66} \mathrm{Zn}_{\text {JMC }}$ signature for the terrestrial natural material background end member was $+0.28 \pm 0.12 \%(2 \sigma)$. The isotopic compositions of the sediments are in line with source mixing involving terrestrial, marine and the major anthropogenic source (i.e., metallurgical waste). Mixing model calculations quantified the contribution of this major anthropogenic source of $\mathrm{Zn}$ as ranging from negligible values in the pre-industrial period to nearly $80 \%$ during periods of electroplating activities. The sedimentary records of this anthropogenic contribution consistently 
decreased in different areas of the bay during the most recent years, reflecting the end of metallurgical activities in 1998. Our work clearly demonstrates that $\mathrm{Zn}$ isotopes trace metallurgical wastes spatially and temporally in coastal areas and mangrove forests and extents the applicability of this novel tool to trace human sources and processes affecting the fate of $\mathrm{Zn}$ in these areas.

\section{Introduction}

Coastal areas worldwide are under strong pressure from anthropogenic pollution as most of the global population and of economic activities are concentrated along the coasts and estuaries (Clark, 1996; Lewis et al., 2011). The main activities include mining and metallurgy and large quantities of waste (slags, ash, liquid effluents) containing elevated concentrations of metals are released during the ore processing, contaminating the surrounding atmosphere, soils, sediments and waters (Hudson-Edwards, 2011; Kossof et al., 2014). Estuaries and mangrove forests act as sinks of the contaminants transported via rivers and their environmental health is seriously threatened by pollutants (MacFarlane et al., 2007; Lewis et al., 2011).

A representative example of coastal areas impacted by metallurgical industry is Sepetiba Bay, a lagoon system with $519 \mathrm{~km}^{2}$ located $60 \mathrm{~km}$ from Rio de Janeiro City, southeastern Brazil. This site has been severely impacted by toxic metals, notably $\mathrm{Zn}$ and $\mathrm{Cd}$, since the implementation of the industrial park in its watershed during the 1960s (Molisani et al., 2004). Zinc content in sediments (Pellegati et al., 2001; Wasserman et al., 2001), oysters (Rebelo et al., 2003; Larcerda and Molisani, 2006;) and brown algas (Amado Filho et al., 1999) exceed 2,000, 80,000 and $800 \mu \mathrm{g} \mathrm{g}^{-1}$, respectively. Cadmium reaches concentrations in sediments that are comparable to the concentrations found in soils of sites with historical of Itai-itai disease outbreak (Kasuya et al., 1992). The main source of these contaminant is an old stack of tailings (estimated as 600,000 tons) derived from a $\mathrm{Zn}$ electroplating plant, which was exposed to the open air for almost 50 years and its materials have been transported to the bay and mangroves of the region (Barcellos et al., 1991, 1992; Barcellos and Lacerda, 1994). The estimated input rates from the electroplating waste into the bay were about $24 \mathrm{t} \mathrm{y}^{-1}$ of $\mathrm{Cd}$ and 3,660 $\mathrm{t}^{-1}$ for $\mathrm{Zn}$ during electroplating activity (Molisani et al., 2004). Other diffuse contaminant sources include the industrial district located along the watershed which host petrochemical, pyrometallurgical, smelter, plastic and rubber production and food and beverage plants, 
and port activities that include sediment remobilization by dredging (Molisani et al., 2004). In addition, the watershed is threatened by increasing population of Sepetiba city (from 0.6 million in 1980 to 1.34 million in 2000) and an inappropriate infra structure to domestic effluents (Leal Neto et al., 2006). Reconstructions of past pollution using coastal sediment cores as archive have shown increasing inputs of $\mathrm{Cu}, \mathrm{Pb}, \mathrm{Cr}, \mathrm{Cd}$ and $\mathrm{Zn}$ (Molisani et al., 2004; Marques et al., 2006; Gomes et al., 2009; Patchineelam et al., 2011), resulting in high enrichment factors of the elements in surface sediments. However, while increasing fluxes and enrichment factors are evidences of the human impact, sources contributions and pathways of the contaminants remain little constrained (Molisani et al., 2004; Ribeiro et al., 2013). Fate and mobility of the metals after release into aquatic systems is controlled by numerous biogeochemical processes including complexation with organic and inorganic ligands, uptake by microorganisms or adsorption onto suspended particulate matter, which will eventually settle on bottom sediments (Langston, 1988; Adriano and Adriano, 2001; Du Laing et al., 2008). The inherent complexity of metal cycles challenge the identification and understanding about their sources, sinks and related risks for the human and biota health.

In recent years, stable isotopes have been critically assessed as potential tool to obtain improved qualitative and quantitative information about sources, pathways and biogeochemical processes of $\mathrm{Zn}$ in the environment (Wiederhold, 2015). This element is ubiquitous in the biosphere and geosphere. It is an essential micronutrient to organisms and an important cofactor of several enzymes, however, in high concentrations can be toxic (Adriano and Adriano, 2001). It is used in alloys, pesticides, electroplating and commonly associated to mining impacts due the economic importance of its ores (Hudson-Edwards et al., 2011, Gordon et al., 2013). Previous work suggested that Zn isotopes fractionate during anthropogenic process such as smelting (Shiel et al., 2010), combustion (Ochoa and Weiss, 2015) and electroplating (Kavner et al., 2008), generating anthropogenic fingerprints isotopically distinct from natural isotopic compositions (Yin et al., 2016). High-temperature processes involved during roasting and smelting of ores tend to fractionate $\mathrm{Zn}$ isotopes in the gas phase, with an enrichment of the lightest $\mathrm{Zn}$ isotopes in air emissions and heavier $\mathrm{Zn}$ isotopes in slags and effluents (Sonke et al., 2008; Borok et al., 2010; Ochoa and Weiss, 2015; Yin et al., 2016). In contrast to these anthropogenic high temperature processes, geological high temperature processes including magmatic differentiation seems not produce significant isotopic fractionation resulting in a homogeneous $\mathrm{Zn}$ isotopic composition for the bulk Earth (Chen et al., 2013). 
The significant difference in the isotopic compositions derived of anthropogenic sources compared to the natural background (soils and rocks, for example) suggest that $\mathrm{Zn}$ isotopes are a powerful tracer of sources capable of discriminate and quantify several pollutant sources, such as vehicle emissions and tire wear (Gioia et al., 2008; Thapalia et al, 2010; Thapalia et al., 2015), wastewaters and sewage (Chen et al., 2008; 2009), mining and metallurgy byproducts (Dolgopolova et al., 2006; Mattielli et al., 2006; Weiss et al., 2007; Sivry et al., 2008).

A critical appreciation of $\mathrm{Zn}$ isotopes as tracers of biogeochemical processes and sources in coastal environmental has been scarce to date. In the Gironde fluvial-estuarine system (France), the isotopic composition of suspended particulate matter (SPM) did not enable the separation of the anthropogenic and natural sources, probably due to on-site remediation of the contamination source and the mixture with natural $\mathrm{Zn}$ in the fluvialestuarine continuum (Petit et al., 2015). In the dissolved phase, the large isotopic variation observed was attributed to adsorption processes in the estuary gradient and maximum turbidity zone (MTZ), rather than sources contributions (Petit et al., 2015). Therefore, the applicability of $\mathrm{Zn}$ as tracer of metallurgical sources in coastal areas remains not conclusive, requiring additional investigations.

Sepetiba Bay offers an ideal environment to test the possible application of $\mathrm{Zn}$ isotopes as tracers of contaminants in coastal areas because the observed isotopes ratios can be correlated to the well-documented history of metallurgic activities in this area. In this work, the stable isotopic composition of $\mathrm{Zn}$ was determined in five sediment cores, surface mangrove sediments, suspended particulate matter (SPM), leaves of mangrove trees, rock samples and ore samples, with the aim of to develop new constraints on the use of a novel tracer for coastal areas to i) identify sources and sinks of anthropogenic $\mathrm{Zn}$, ii) to reconstruct the temporal and spatial evolution of $\mathrm{Zn}$ contamination, iii) to verify the influence of estuarine biogeochemical processes on the $\mathrm{Zn}$ isotopic signature during the element transport and deposition and for last, iv) to investigate the effects of anthropogenic contamination on the $\mathrm{Zn}$ isotope composition of mangrove leaves.

\section{Study area}

\subsection{General characteristics}

Sepetiba Bay (Fig.1) is a 519-km², semi-enclosed water body located $60 \mathrm{~km}$ south of Rio de Janeiro City. In the vicinity, a wide intertidal area with about $40 \mathrm{~km}^{2}$ of mangrove 
ecosystems has developed (Leal Neto et al., 2006; Roncarati and Carelli, 2012). Water circulation in the bay is controlled by tides and the pattern of surface currents tends to clock direction, creating a preferential deposition area along the northern coast (Neto et al., 2006; Roncarati and Carelli, 2012). Main river estuaries and extensive mangrove vegetation occur in the northern and eastern portions of the bay, respectively. Nine rivers drain an extensive watershed of approximately $2,654 \mathrm{~km}^{2}$, which includes agricultural, industrial and urban areas. The geological setting is composed by Quaternary sediments and granite-gneisses rocks. Three main waterways (Guandu, Guandu-Mirim and Guarda rivers) contribute with more than $>90 \%$ of watershed's total input of fresh water to the bay. The waters of , Guarda and Guandu-Mirim rivers reach the bay by artificial channels, crossing an industrial park (Molisani et al., 2004; Roncarati and Carelli, 2012). The São Francisco channel, with an annual flow of $6.5 \times 10^{9} \mathrm{~m}^{3}$, is responsible for over $86 \%$ of the total freshwater runoff input (Molisani et al., 2004). The extensive contribution of sediments to the bay coming from the rivers result in sedimentation rates of 0.12 to 1.3 cm per year (Smoak and Patchineelam, 1999; Molisani et al., 2004; Marques et al., 2006; Gomes et al., 2009). Numerous industrial plants are located in the bay watershed, including a large metallurgical complex between the Guandu and São Francisco channels at the border of the bay, while two important harbors operate in the bay area, besides a past electroplating industry refuse pile located at the northern bay margin (Fig.1), which promoted the major anthropogenic Zn input to the bay (Molisani et al., 2004).

\subsection{History of environmental impacts}

The population of Sepetiba Bay drainage basin increased significantly in the 1970s, from 600,000 to up 1.34 million today, resulting in an inadequate infrastructure to support the population growth (Leal Neto, 2006). In the 1960s, an electroplating plant started to operate, close to the Itaguaí harbor (Fig.1). In 1996, the electroplating plant represented one of the three largest producers of zinc in Brazil, with a total capacity of 60.000 tons per year. The zinc purification process used silicate ores (calamine and willemite) acquired from Vazante (Minas Gerais, Brazil), the most important Zn deposit in Brazil. The ores were crushed and leached by sulfuric acid followed by filtration and purification of solution. The purified solution was then carried to electrolytic cells where the zinc plates were produced. After this, the plates underwent smelting and casting processes (Barone, 1973). The low production efficiency (75 to 90\%) of this process contributed 
for the high production of wastes (Barcellos and Lacerda, 1994), that had inadequate contention.

The electroplating wastes (estimated to about 600,000 tons, and containing about 200 tons of $\mathrm{Cd}$ and 50,000 tons of $\mathrm{Zn}$ ) were disposed in an area adjacent to the small tidal creek of Saco do Engenho (Fig.1). Rainfall continuously leached the waste tailing to this channel and to the bay (Barcellos et al., 1991). To reduce the transport of these materials to the coastal area a dike was built between the bay and the tailing disposal site in 1984 . However, its rupture in the 1996 caused a large input of contaminants to the surrounding bay area. In 1998, the industrial activities of this electroplating plant ceased (Molisani et al., 2004).

Several studies identified high metal concentrations in biota and sediment compartments of Sepetiba Bay, particularly for Zn and Cd (Amado Filho et al., 1999; Pellegati et al., 2001; Wasserman et al., 2001; Rebelo et al., 2003; Lacerda and Molisani, 2006). Some authors suggest that the complex hydrodynamics of the system and sediment re-suspension eventually lead to large transport of suspended particles before its deposition, promoting the remobilization and the dispersion of the contaminants along different zones of the bay (Barcellos et al., 1997). Computational modeling of the lagoon hydrodynamics shows a trend of fine sediments deposition along the northeastern coastal area of the bay, where the tidal flats and mangroves acts as sinks of contaminants (Montezuma, 2013). In the mangroves and mud flats sediments, the anoxic and organic matter-rich conditions result in the formation of insoluble metallic sulfides and metalorganic matter complexes, as indicated for $\mathrm{Zn}$ and other toxic metals $(\mathrm{Cd}, \mathrm{Cu}, \mathrm{Ni}$ and $\mathrm{Pb})$ along the bay area (Lacerda et al., 1993; Machado et al., 2008; Andrade et al., 2012; Ribeiro et al., 2013).

\section{Materials and Methods}

\subsection{Sampling and sample preparation}

The sediment cores were collected from five different locations within the Sepetiba Bay (Fig.1). The core T1 was sampled within a white mangrove (Laguncularia racemosa) stand, located into the Saco do Engenho tidal creek, representing the contamination hot spot due to the leaching process of the electroplating wastes and deposition in this area. The other cores were collected in subtidal or intertidal mud flats located along the inner 
bay areas. The core T2 was collected next to the Saco do Engenho channel mouth, while the core T3 was located near the mouth of the São Francisco channel. The T4 core was collected in Enseada das Garças, in a tidal flat located in the northeastern bay area, close to an ecological reserve with mangrove vegetation, but under the influence of anthropogenic activities, such as the discharge of untreated domestic sewage. In contrast to the cores collected close to the northeastern shore, the T5 core was collected near the Marambaia sandbar and the main communication of the bay with the open sea. All sediment cores were taken using $6 \mathrm{~cm}$-diameter, $60 \mathrm{~cm}$-length acrylic tubes, and sectioned in the field at $5 \mathrm{~cm}$ intervals. Each sub-sample was stored in polyethylene bags and kept frozen. The samples were dried at $40{ }^{\circ} \mathrm{C}$, crushed and sieved at $63 \mu \mathrm{m}$. This grain size fraction $(<63 \mu \mathrm{m})$ was used for elemental and isotopic analyses.

Surface sediments were collected at three different mangrove sites (Fig.1), during low tide. The first is located in the Saco do Engenho (station MSE), the second is located close the mouth of São Francisco channel (station MSF) and the third is located in the mangrove of Enseada das Garças (station MENS). At each sampling station, three superficial ( 0-5 cm depth) sediment replicates were sampled into polyethylene bags and kept frozen. The surface sediment samples were processed as described for sediment cores. In the three sampling stations, L. racemosa trees colonized the sediments. $L$. racemosa leaves were also sampled in triplicate from trees surrounding the sampled sediments. The leaf samples were stored in plastic bags until the return to the laboratory for cleaning with ultrapure water. These samples were dried at $80^{\circ} \mathrm{C}$ during $24 \mathrm{~h}$ and finely ground for homogenization.

The sampling locations for suspended particulate matter (SPM) were chosen with the aim to characterize: 1) the fluvial material, which includes the natural terrestrial material and potential contaminants brought to the bay by the San Francisco Channel and Guandu Rivers, 2) the contaminant wastes transported by the creek that cross the Saco do Engenho's mangrove, and 3) the ocean particulate matter that enters the bay to the west (Fig.1). The SPM samples from the rivers were collected $6 \mathrm{~km}$ upstream during the low tide to represent best the fluvial inputs. Conductivity was controlled to guarantee the sampling in the fresh waters. Bottles for sampling were washed overnight in sub-boiling $\mathrm{HCl}$ and rinsed three times with pure water prior to using in the field. After sample collection, between 150 and $500 \mathrm{ml}$ of water was filtered through a $0.45 \mu \mathrm{m}$ acetate cellulose membrane previously dried and weighted. Back to the laboratory SPM samples were dried and weighed again to calculate the mass of the suspended material. 
Granite rock samples were collected around a quarry located at north of the Saco do Engenho's mangrove. The rocks were split in two group and crushed. The two groups were pulverized separately, constituting two aliquots representative for the geology of the study area. Three willemite ores originated from hypogene non-sulfide zinc deposit from the Vazante Mine, Minas Gerais, Brazil were used to represent the main mineral refined during the industrial electroplating process (Barone, 1973).

\subsection{Sample treatment}

All reagents used for the samples digestion were prepared using > $18.2 \mathrm{M} \Omega \mathrm{H}_{2} \mathrm{O}$ (Nanop System $\left.{ }^{\circledR}\right)$ and ultra-pure acids (Merck $\left.{ }^{\circledR}\right)$ distillated by sub-boiling in teflon stills. The chemical procedures for trace elements were performed under clean-air conditions and evaporations were conducted in clean boxes. The samples were weighed in Savillex ${ }^{\circledR}$ Teflon beakers with sample masses ranging from 20-100 mg (sediments, rocks and certified reference materials, i.e. BCR-2 and BHVO-2, USGS) and 5-10mg for willemite ores were digested on a hot plate using a multiple-step acid procedure with $\mathrm{HF}, \mathrm{HNO}_{3}$, $\mathrm{HCl}$. Suprapur $\mathrm{H}_{2} \mathrm{O}_{2} 30 \%$ (Merck®) was used to oxidize organic matter in some sediment samples. Subsequently, the samples were evaporated to dryness on a hot plate and $1 \mathrm{ml}$ of concentrated $\mathrm{HNO}_{3}$ was added to drive off the remaining HF. After, the samples were dissolved in $6 \mathrm{M} \mathrm{HCl}$ evaporated to dryness again and redissolved in $2 \mathrm{M} \mathrm{HCl}$. From each digested sample, two separated aliquots were taken for chemical $\mathrm{Zn}$ separation and trace elements analysis. Leaf samples were digested using a microwave system (Speedwave 4, Berghof) and concentrated acid mixing ( $\mathrm{HF}, \mathrm{HCl}$ and $\mathrm{HNO}_{3}$ ). After digestion, the solution was transferred to Savillex ${ }^{\circledR}$ Teflon beakers dried on a hot plate, the remaining $\mathrm{HF}$ drive off by concentrate $\mathrm{HNO}_{3}$ addition and subsequently dissolved in $6 \mathrm{M} \mathrm{HCl}$, dried again and re-dissolved in $2 \mathrm{M} \mathrm{HCl}$.

For major elements analysis, ca $20 \mathrm{mg}$ of sediment and rock samples were weighted in platinum crucible and digested by alkaline fusion with lithium metaborate followed by dissolution in $2 \mathrm{M} \mathrm{HCl}$.

\subsection{Elemental analysis}

Major elements (Al, Fe, Ti, Ca, Mg, P, Mn and Si) and trace elements ( $\mathrm{Zn}, \mathrm{Cu}, \mathrm{Ni}$ and Cr) were analyzed using ICP-OES (ICP Spectro Ciros Vision, Spectro). Potassium was 
analyzed by AAS (Analyst 200, Perkin Elmer). Multi-element standard solutions (Merck $\left.{ }^{\circledR}\right)$ were used to produce external calibration curves. Certified reference materials (BHVO-2 and BCR-2 basalts from USGS; 1646a estuarine sediment and 1573a from NIST) and an internal basalt standard were used to assess the accuracy of analysis. The accuracy expressed as percentage relative error were always within $10 \%$ of the certified values for all the elements studied.

Energy dispersive spectroscopy (EDS) analysis was performed using an electron microprobe (Jeol JXA-8230) with scanning electron microscopy (SEM). The sediment samples were deposited in double-sided tape over laminar glass. The samples were coated by gold sputtering using the coating system of Quorum Q150R ES.

\subsection{Enrichment factor, bio-concentration factor and multivariate statistic}

The enrichment Factor (EF) was used to identify and quantify anthropogenic impact:

$$
\mathrm{EF}=([\mathrm{X}] /[\mathrm{Al}])_{\text {sample }} /([\mathrm{X}] /[\mathrm{Al}])_{\text {reference }}
$$

where $\left([\mathrm{X}] /[\mathrm{Al}]_{\text {sample }}\right)$ represents the concentration ratio in the sample, $([\mathrm{X}] /[\mathrm{Al}])_{\text {reference }}$ the concentration ratio in the rock granite collected near the Sepetiba bay, $[\mathrm{X}]$ is the element of interest and [Al] is the reference element with no significant anthropogenic source.

The biota-sediment accumulation factor (BSAF) was used to assess bioaccumulation of $\mathrm{Zn}$ in biota relative to the sediments (Arnot and Gobas, 2006). The BSAFs values were calculated dividing average $\mathrm{Zn}$ leaf concentration to corresponding average $\mathrm{Zn}$ concentration of the sediment.

A multivariate approach (Principal Component Analysis -PCA) using the software SPPS ${ }^{\circ}$ (IBM) was performed as auxiliary tool to interpret the set of data of sediment cores. A correlation matrix with varimax rotation was used to calculate the factor loads and the sample factor scores. The principal components (PCs) that had eigenvalues higher than one were selected (Voudouris et al., 1997). The communalities values of all variables equal or higher than 0.5 was used as criterions for PCA results acceptance.

\subsection{Zinc isotope ratio analysis}

Prior to the mass spectrometry, Zn was separated from matrix components by anion exchange chromatography using a modified procedure from that proposed by Maréchal 
et al., (1999). Bio-Rad PolyPrep columns were filled with $2.0 \mathrm{ml}$ of the anion exchange resin AG-MP1 (100-200 mesh size) and 1 to $4 \mu \mathrm{g}$ of sample were loaded in $2 \mathrm{M} \mathrm{HCl}$. Once the sample is loaded, matrix elements are eluted with $20 \mathrm{ml}$ of $2 \mathrm{M} \mathrm{HCl}$. Then $\mathrm{Zn}$ is eluted with $12 \mathrm{ml}$ of $0.5 \mathrm{M} \mathrm{HNO}_{3}$. The $\mathrm{Zn}$ purified samples were dryness and redissolved in $0.05 \mathrm{M} \mathrm{HNO}_{3}$. To test for the complete recovery aliquots of $\mathrm{Zn}$ purified samples were measured by ICP-MS. The yield was $99 \pm 7 \%$.

Zinc isotopic ratios were measured using the ThermoFinnigan Neptune MC-ICPMS at the Laboratório de Geocronologia of the University of Brasília and at the Laboratorio de Geocronologia of the University of Sao Paulo. The introduction interface consisted of quartz glass spray chamber (cyclone + standard Scott double pass) coupled with a low flow PFA nebulizer $\left(50 \mu \mathrm{min}^{-1}\right)$. After a minimum of two hours of warm up and tuning to achieve the best sensibility, the analytical sequences ran automatically using a Cetac ASX-100 autosampler and low mass resolution collector slits. Masses 62 (Ni), 63 $(\mathrm{Cu}), 64(\mathrm{Zn} / \mathrm{Ni}), 65(\mathrm{Cu}), 66(\mathrm{Zn}), 67(\mathrm{Zn})$ and $68(\mathrm{Zn})$ were detected simultaneously. A $\mathrm{Cu}$ standard (NIST 976) was added to all samples and matched in the proportion 1:1 (300 $\mu \mathrm{g} / \mathrm{ml}$ in $\left.0.05 \mathrm{M} \mathrm{HNO}_{3}\right)$.

The $\mathrm{Zn}$ isotopes ratios were measured relative to the in-house $\mathrm{Zn}$ single element standard MERCK Lot \#9953 labeled henceforward as Zn UnB standard. The standardsample bracketing technique was used, i.e, each sample was bracketed by standard solution mixture ( $\mathrm{Zn} \mathrm{UnB}$ and Cu NIST 976) with rinses between sample and standard analyses with $3 \%(\mathrm{v} / \mathrm{v}) \mathrm{HNO}_{3}$. Instrument blanks were analyzed after each sample and each bracketing standard and on-line subtracted. Typical sample and standard signals were $3 \mathrm{~V}$ to ${ }^{64} \mathrm{Zn}$ and ${ }^{65} \mathrm{Cu}$ masses. Blank measurements consisted of 1 block of 10 cycles (8s) while samples and standards were measured in 2 blocks of 20 cycles of $8 \mathrm{~s}$ each. For a single measurement (40 cycles), internal precision ranged from 3 to $8 \mathrm{ppm}(2 \sigma)$. The raw ratios were corrected for instrumental mass fractionation using the exponential law based and the certified ratio (0.4456) for $\mathrm{Cu}$ of the NIST SRM 976 standard.

\subsection{Zinc isotopic data presentation, reproducibility and accuracy}

The $\delta^{66} \mathrm{Zn}$ of the samples were then calculated as the deviation of the mass bias corrected $\mathrm{Zn}$ isotope ratio of the samples from the mean of the mass bias-corrected $\mathrm{Zn}$ isotopes rations of the bracketing standards: 


$$
\delta^{66} \mathrm{Zn}(\%)=\left(\frac{{ }^{66} \mathrm{Zn} /{ }^{64} \mathrm{Zn}_{\text {sample }}}{{ }^{66} \mathrm{Zn} /{ }^{64} \mathrm{Zn}_{\text {standard }}}-1\right) \quad \text { eq. } 1
$$

$\mathrm{Zn}$ isotopic data reported in this study are expressed relative to the Johnson Matthey Company 3-0749-L ( $\mathrm{JMC}_{3-0749-\mathrm{L})}$ reference standard calibrated against our $\mathrm{Zn} \mathrm{UnB}$ standard $\left(\Delta \mathrm{Zn}_{\mathrm{JMC}-\mathrm{UnB}}=+0.17 \%\right)$. Error propagations were used to calculate the error (expressed as $2 \sigma$ ) of $\delta^{66} \mathrm{Zn}_{\mathrm{JMC}}$ values. The calibration is based in a total of $n=30$ analysis $( \pm 0.05,2 \sigma)$. More methodological details concerning the $\mathrm{Zn}$ isotopes measurements in our laboratories can be found in Araújo et al.(2016).

For asses the accuracy of analysis, the Zn IRMM 3702 were measured two and three times along the session analysis yielding a $\delta^{66} \mathrm{Zn}_{\text {JMC }}$ value of $-0.27 \pm 0.06 \%$ o $(n=30$, $2 \sigma$ ), comparable to values published previously (Moeller et al., 2012). Different certified reference were prepared in different replicates (full protocol including digestion, ionexchange chromatography and replicated isotopic analyses) to assess the accuracy analytical and procedural: BHVO-2 and BCR- 2 basalts $(n=5)$, to AGV-2 andesite $(n=1)$ and NIST 1646a estuarine sediment $(n=2)$. Each replicate was measured twice. The $\delta^{66} \mathrm{Zn}_{\text {JMC }}$ values obtained to BHVO-2 and BCR-2 basalts were $+0.25 \pm 0.10 \%$ o $(2 \sigma)$ and $+0.25 \pm 0.08 \%$ o $(2 \sigma)$ respectively. The $\delta^{66} \mathrm{Zn}_{\mathrm{JMC}}$ value obtained to AGV-2 was $+0.29 \pm 007$ $(2 \sigma)$. The results agree well with those reported in the literature (Archer and Vance, 2004; Chapman et al., 2006; Sonke et al., 2008; Moynier et al., 2010; Chen et al., 2013). The $\delta^{66} \mathrm{Zn}_{\text {JMC }}$ value for 1646 a estuarine sediment was $+0.32 \pm 0.07 \%$ o, $2 \sigma, n=8$ ), close to silicate rocks, marine sediments $(+0.23 \pm 0.08 \%, 2 \sigma, n=20$ Maréchal et al., 2000) and sapropels $(+0.28 \pm 0.02 \%, 2 \sigma, n=3$, Maréchal et al., 2000). The average of external reproducibility of unknowing samples was $\pm 0.04 \%(2 \sigma)$ (one replicate, two or three measurements). The average reproducibility of the certified reference material $\mathrm{Zn}$ IRMM and unknown samples was $0.06 \%(2 \sigma)$. This value was considered the external reproducibility of the method and applied to all samples in all tables and graphs of this work.

\section{Results}

\subsection{Zinc isotopic compositions and enrichment factors of sediment cores}

The $\delta^{66} \mathrm{Zn}_{\mathrm{JMC}}$ values of the sediment cores are shown in Table 1 and Fig. 2. We find a significant range of $\mathrm{Zn}$ isotopic signatures within the individual profiles and between the 
cores. Core T1 (sampled within the mangrove of the Saco do Engenho channel, the hot spot of the contamination from the electroplating waste) showed extremely high $\mathrm{Zn}$ concentrations, resulting in EF values varying between 117 and 784 . The $\delta^{66} \mathrm{Zn}_{\text {JMC }}$ values in this core ranged from +0.72 to $+1.15 \%$. The heaviest isotopic composition found $\left(\delta^{66} \mathrm{Zn}_{\mathrm{JMC}}=+1.15 \%\right)$ was observed in the deeper sediments $(80-85 \mathrm{~cm}$ depth $)$ from this core. From the core base to the $50 \mathrm{~cm}$ depth, the isotopic signatures decreases toward lighter values, reaching $+0.72 \%$. From $50 \mathrm{~cm}$ depth to upper layers, the isotopic signatures shows large variations, with peaks of +1.03 and $+1.00 \%$ at 25 and $10 \mathrm{~cm}$ depth, respectively (Fig. 2). Core T2 (located near to the Saco do Engenho creek mouth) also has very high EF, varying between 68 to 697, and heavier isotopic compositions, with a smaller range of $\delta^{66} \mathrm{Zn}_{\mathrm{JMC}}$ values $(+0.65$ to $+0.83 \%$ ) than core $\mathrm{T} 1$. We find a slight upward shift to heavier isotopic composition in this core, although most isotopic signatures are statistically not differentiable (taking the error bars into account, $\pm 0.06 \%$ ). Core T3 (São Francisco channel mouth) displays EF values between 1.7 to 8.2 and the $\delta^{66} \mathrm{Zn}_{\text {JMC }}$ values range between +0.30 and $+0.75 \%$. This profile shows a progressive increase of $\delta^{66} \mathrm{Zn}_{\mathrm{JMC}}$ values and EF from bottom to the middle, with a salient peak at 20 $\mathrm{cm}$ depth corresponding to the heaviest $\delta^{66} \mathrm{Zn}_{\mathrm{JMC}}$ value $(+0.75 \%$ o) and highest EF value (8.2). Following this peak, $\delta^{66} \mathrm{Zn}_{\mathrm{JMC}}$ and EF values decrease to $+0.46 \%$ and 181 in the core top. Core T4 (Enseada das Garças), collected in a tidal flat more than $20 \mathrm{~km}$ away from the point source of metallurgic wastes, displays higher EF than T3 core (between 11.9 and 18.2). The $\delta^{66} \mathrm{Zn}_{\mathrm{JMC}}$ values from this core show isotopically heavy $\mathrm{Zn}(+0.67$ to $+0.74 \%$ ), comparable to $\mathrm{T} 1$ and $\mathrm{T} 2$ cores collected near the old wastes of the metallurgical refining. From the base to the top, $\delta^{66} \mathrm{Zn}_{\mathrm{JMC}}$ and EF values decrease slightly (Fig.2). Core T5 (Marambaia) exhibits EF values higher than T3 core and lower than cores T1, T2 and T4, while the $\delta^{66} \mathrm{Zn}_{\mathrm{JMC}}$ values are comparable to core T3. From the base $(45 \mathrm{~cm})$ to $35 \mathrm{~cm}$ depth, EF and $\delta^{66} \mathrm{Zn}$ values increase from 10.5 and $+0.60 \%$ to 14.2 and $+0.71 \%$, respectively. Above $35 \mathrm{~cm}$ depth, $\mathrm{EF}$ and $\delta^{66} \mathrm{Zn}$ values decreased continuously until the values of 6.9 and $+0.36 \%$, respectively.

Correlations between $\delta^{66} \mathrm{Zn}_{\mathrm{JMC}}$, Zn concentration and enrichment factor (EF) for each core are assessed in Fig.3A and 3B, respectively. We find a strong positive correlation between $\delta^{66} \mathrm{Zn}$ values and enrichment factor in cores T2, T3, T4 and T5 $\left(\mathrm{R}^{2}=\right.$ $0.90,0.87,0.84$ and $0.74, \mathrm{p}<0.01$, respectively; Fig. 3B). The T1 core displays an absence of correlation for the whole profile, but a moderate correlation $\left(\mathrm{R}^{2}=0.51\right)$ from the top until $35 \mathrm{~cm}$. An overview of all results plotted in the Fig. 3A and 3B reveals a 
general model of mixing between the samples of lithogenic origin (granite rock and T2 core) and those collected in the metallurgic impacted zone (samples from the Saco do Engenho creek). The T4 core slightly deviates from this mixing trend, suggesting the influence of other source of $\mathrm{Zn}$, as the visible discharge of sewage near the sampling site.

\section{2 $\mathrm{Zn}$ isotopic compositions of rocks and willemite ores}

The granites have average $\delta^{66} \mathrm{Zn}_{\text {JMC }}$ value of $+0.21 \pm 0.01 \%$ o $(2 \sigma, n=2)$. This value is well within the range of igneous rocks reported in the literature (from +0.20 to $+0.40 \%$, Cloquet et al., 2007; Chen et al., 2013). The willemite ores have $\delta^{66} \mathrm{Zn}_{\mathrm{JMC}}$ values ranging between -0.1 and $+0.14 \%$ o (average of $0.03 \pm 0.24 \%, n=3$ ). These values are well in the range of $+0.16 \pm 0.20 \%$ proposed for sphalerite ores from various deposits worldwide (Mason et al., 2005; Wilkinson 2005; Sonke et al., 2008; Kelly et al., 2009).

\section{3 $\mathrm{Zn}$ isotopic compositions of surface sediments and mangrove leaves}

The results for surface sediments and mangrove leaves (Laguncularia racemose) are shown in table 2 and presented in the Fig.4. The surface sediments collected in the mangrove close to the São Francisco Channel (station MSF) display $\delta^{66} \mathrm{Zn}_{\text {JMC }}$ values between +0.44 and $+0.49 \%$ (average of $+0.47 \%$ ), slightly heavier than the values found in the mangrove of Enseada das Garças (station MENS) ranging between $+0.36 \%$ to $+0.42 \%$ (Fig.4A). Samples from the Saco do Engenho mangroves (station MSE) exhibit the highest values, ranging between +0.80 and $+0.84 \%$ (Fig. $4 \mathrm{~A}$ ), which are very close to the values obtained to the SPM samples collected in the mouth of Saco do Engenho channel (Table 3). The highest $\mathrm{Zn}$ concentrations are found in the MSE station (21,551 \pm $\left.2,072 \mu \mathrm{g} \cdot \mathrm{g}^{-1}, 1 \sigma, n=3\right)$, intermediate values in the MENS stations $\left(316 \pm 12 \mu \mathrm{g} \cdot \mathrm{g}^{-1}, 1 \sigma\right.$, $n=3)$, and the lowest values in the MSF (164 $\left.\pm 17 \mu \mathrm{g} \cdot \mathrm{g}^{-1}, 1 \sigma, n=3\right)$.

The average $\mathrm{Zn}$ concentrations of $L$. racemose leaves in the mangrove stations show the same pattern observed for sediments, i.e. the highest concentrations are observed in the MSE station $\left(47 \pm 5 \mu \mathrm{g} . \mathrm{g}^{-1}, 1 \sigma, n=3\right)$, followed by the MSENS $\left(25 \pm 2 \mu \mathrm{g}^{-g^{-1}}, 1 \sigma\right.$, $\mathrm{n}=3)$ and MSF (15 $\left.\pm 2 \mu \mathrm{g} \cdot \mathrm{g}^{-1}, 1 \sigma, n=3\right)$ stations (Fig. 4A). The leaves collected in the stations with higher degree of $\mathrm{Zn}$ contamination in sediments (MSE and MSF stations) display similar $\delta^{66} \mathrm{Zn}_{\mathrm{JMC}}$ values $(+0.09 \pm 0.04 \%$ and $+0.08 \pm 0.10 \%$ o $(2 \sigma, n=3)$, respectively), while heavier $\delta^{66} \mathrm{Zn}_{\text {JMC }}$ values $(+0.23 \pm 0.02 \%, 2 \sigma, n=3)$ were observed 
for leaves from MSF station, which have the lower $\mathrm{Zn}$ accumulation heavier $\delta^{66} \mathrm{Zn}_{\mathrm{JMC}}$ values around $+0.23 \pm 0.02 \%$ o $(2 \sigma, n=3$, Fig. $4 \mathrm{~A})$.

All BSAFs values are lower than 1.0, with the MSF station presenting the highest value (0.92), followed by MSENS station (0.073). The MSE station presented the lowest BSAF value of 0.003 . Notable tendencies of inverse correlations are observed between BSAFs values and the $\mathrm{Zn}$ concentrations of leaves and sediments of the mangrove (Fig.4B).

The isotopic fractionation between plants and sediments $\left(\Delta_{\text {plant-sediment }}\right)$ varies between the mangroves stations, ranging from -0.73 to $-0.24 \%$. The $\Delta_{\text {plant-sediment values }}$ of mangrove stations show an inverse tendency in relation to the $\mathrm{Zn}$ concentrations of surface sediments and leaves (Fig.4C), and a positive trend with the BSAF values (Fig.4C).

\section{4 $\mathrm{Zn}$ isotopic compositions of suspended particulate matter (SPM)}

The results for the SPM are presented in the table 3. The SPM from the rivers show an average concentrations of $99 \pm 13 \mu \mathrm{g}^{-\mathrm{g}^{-1}}(1 \sigma, n=2)$ and isotope signatures of +0.27 $\pm 0.11 \%$ o $(2 \sigma, n=3)$, which falls in the range of $\delta^{66} \mathrm{Zn}_{\mathrm{JMC}}$ values typically for the Earth crust of $+0.28 \pm 0.5 \%$ (Fig.3A; Chen et al.,2013). The SPM samples collected at the west side of the bay, being strongly influenced by the marine source (B1, B2, B3 samples), display $\delta^{66} \mathrm{Zn}_{\mathrm{JMC}}$ values around $+0.45 \pm 0.03 \%$ o $(2 \sigma, n=3)$ and low $\mathrm{Zn}$ concentrations of about $45 \pm 3 \mu \mathrm{g} \cdot \mathrm{g}^{-1}(1 \sigma, n=3)$. These $\delta^{66} \mathrm{Zn}_{\text {JMC }}$ values are slightly above the range of +0.2 to $+0.4 \%$ commonly reported for silicate rocks (Fig.3A; Cloquet et al., 2007; Chen et al.2013), but within of the range of isotopic compositions of carbonates rocks (from +0.07 to $1.34 \%$, Fig.3A; Kunzmann et al., 2013) and seawater (+0.53 $\pm 0.14 \%$; Zhao et al., 2014). The samples collected close to the mouth of Saco do Engenho channel present $\delta^{66} \mathrm{Zn}_{\mathrm{JMC}}$ values ranging from +0.83 to $+0.88 \%$ and high $\mathrm{Zn}$ concentrations of $1,242 \pm$ $198 \mu \mathrm{g} . \mathrm{g}^{1}(1 \sigma, n=3)$. These $\delta^{66} \mathrm{Zn}_{\mathrm{JMC}}$ values are similar to those reported for wastes and slags of metallurgy industry (from +0.59 to $+1.49 \%$, Fig.3A; Sivry et al., 2008; Juillot et al., 2011; Yin et al., 2015). This range of $\delta^{66} \mathrm{Zn}_{\text {JMC }}$ values excludes the discrepant "Dunet sample" reported by Sivry et al.(2008), which presents $\delta^{66} \mathrm{Zn}$ values of $+0.18 \pm 0.04 \%$. 


\subsection{Major and trace elements profiles of sediment cores}

The depth profiles of the major elements $\mathrm{Al}, \mathrm{Fe}, \mathrm{Mn}$ and $\mathrm{P}$ are shown in Fig. 2. The depth profiles of $\mathrm{Ca}$, Ti and $\mathrm{Si}$ are shown in the Appendices $\mathrm{A}$. The Fe/Mn ratio is included to assess redox processes, as supported by the higher susceptibility of Mn to be remobilized from the solid phase under reduced sedimentary conditions than observed for $\mathrm{Fe}$ (Burdige, 1993). The profile of T1 core, collected in the mangrove of Saco do Engenho, shows the largest variations for all major elements. The other cores show less variations for $\mathrm{Ca}, \mathrm{Si}, \mathrm{Al}$ and $\mathrm{Fe}$ profiles.

The enrichment factor $(\mathrm{EF})$ of the trace elements $\mathrm{Cu}, \mathrm{Ni}$ and $\mathrm{Cr}$ are shown in Table 1 and their profiles are shown in Appendice A. All cores show high EF for the trace metals analyzed. Zinc and $\mathrm{Cu}$ profiles show similar profiles, while Ni display no changes from bottom to the top layers and $\mathrm{Cr}$ exhibits slight variations in the cores. The highest $\mathrm{EF}$ values found are for $\mathrm{Cu}$ and $\mathrm{Zn}$ in the $\mathrm{T} 1$ and $\mathrm{T} 2$ core (i.e. the northeastern region of the bay, Fig.1) and for $\mathrm{Cr}$ and $\mathrm{Ni}$ in the $\mathrm{T} 5$ core (southern region of the bay, close the open sea, Fig.1). The T3 core (located in the mouth of the estuary, Fig.1) displays high concentrations of $\mathrm{Cr}$ and the lowest concentrations of $\mathrm{Zn}$ and $\mathrm{Cu}$. The $\mathrm{T} 1 \mathrm{core}$, displays large variations within the profile for all the trace elements, similarly to the major elements.

\subsection{Multivariate statistics of sediments cores in Sepetiba bay}

The principal component analysis (PCA) separates the variables determined in the sediment cores into three principal components (PC), explaining $76 \%$ of the total variance. $\mathrm{PC} 1$ accounts for $33.9 \%$ of the variance and includes the elements $\mathrm{Ca}, \mathrm{Mg}, \mathrm{Mn}$, $\mathrm{Ni}, \mathrm{Cr}$. PC2 accounts for $32.5 \%$ of total variance and includes $\mathrm{Zn}, \delta^{66} \mathrm{Zn}, \mathrm{Fe}, \mathrm{Cu}$ and $\mathrm{P}$. PC3 accounts for $9.6 \%$ of the total variance and includes Al. The plots displaying the variable factor loads and the sample factor scores of PC1 and PC2 are shown in the Fig.5A and $5 \mathrm{~B}$, respectively. A fourth group of variables $(\mathrm{Si}, \mathrm{K}$ and $\mathrm{Ti})$ is identified in the plot of factor loads (Fig.5A) and shows an inverse correlation with the main variables associated to $\mathrm{PC} 2\left(\mathrm{Zn}, \delta^{66} \mathrm{Zn}, \mathrm{Fe}, \mathrm{Cu}\right.$ and $\left.\mathrm{P}\right)$. More details as eigenvalues and factor loads are included in the Appendices B1 and B2.

Strong correlation are found between $\mathrm{Zn}$ and $\mathrm{Cu}(\mathrm{r}=0.77, \mathrm{p}<0.01)$ and between $\mathrm{Ni}$ and $\mathrm{Cr}(\mathrm{r}=0.86, \mathrm{p}<0.01)$. Zinc and $\mathrm{Cu}$ are associated with $\mathrm{Fe}(\mathrm{r}=0.64, \mathrm{p}<0.01)$ and $\mathrm{Ni}$ 
and $\mathrm{Cr}$ are associated with $\mathrm{Mn}(\mathrm{r}=0.64, \mathrm{p}<0.01$ and $\mathrm{r}=0.75, \mathrm{p}<0.01$, respectively). The $\delta^{66} \mathrm{Zn}$ values showed a strong correlation with $\mathrm{Zn}(\mathrm{r}=0.66, \mathrm{p}<0.01)$ and $\mathrm{Fe}(\mathrm{r}=0.60, \mathrm{p}<$ $0.01)$.

The plot of sample factor scores show the variations of the geochemical composition of sediment cores (Fig. 5B). The T1 core sub samples presents the highest factor scores associated to the PC2 $\left(\mathrm{Zn}, \delta^{66} \mathrm{Zn}, \mathrm{Fe}, \mathrm{Cu}\right.$ and P) and T3 core sub samples are associated to $\mathrm{Si}, \mathrm{K}$ and $\mathrm{Ti}$ variables (Fig.5B). The T4 core showed an intermediate association between these two elemental groups. In contrast, the samples of T5 core (collected close the open sea) were highly correlated to $\mathrm{Ca}, \mathrm{Mg}, \mathrm{Mn}, \mathrm{Ni}$ and $\mathrm{Cr}$ of PC2.

\subsection{SEM/EDS analysis of sediments}

Scanning electron microscope (SEM) images shows a mixture of pyrites, diatoms shells, organic matter and clay minerals. The frequent occurrence of pyrite, as isolated or as framboid crystals evidences sulfate-reduction stimulation (Fig.6). Chemical analysis using EDS suggests that the sediments are dominated by clay minerals $\left(\mathrm{SiO}_{2}\right.$ and $\mathrm{Al}_{2} \mathrm{O}_{3}$ are above $70 \mathrm{wt} . \%)$, by quartz particles $\left(\mathrm{SiO}_{2}\right.$ representing above $\left.72 \mathrm{wt} \%\right)$ and by organic matter (associated with inorganic particles).

\section{Discussion}

\subsection{Identifying sediment sources and processes with multivariate statistics}

The PCA analysis (Fig. 5A) reveals different groupings of variables. The association of $\mathrm{Si}, \mathrm{K}, \mathrm{Ti}, \mathrm{Fe}$ and $\mathrm{Al}$ represent terrestrial material reaching the bay, i.e. primary and secondary minerals originated from the weathering and erosion of silicate rocks and soils. The core T3, located in the São Francisco estuary, displays the largest factor scores for these elements, suggesting a major contribution of terrigenous materials. The association of $\mathrm{Zn}$ and $\mathrm{Cu}$ reflects the common origin from the waste produced by the electroplating industry during 60's to end of 90's years (Lacerda et al., 1987; Gomes et al., 2009). The high factor scores of T1, T2 and T3 core and MSE associated to these elements in the PC1 support the region of Saco do Engenho as the contamination hot spot of these metals. The association of $\mathrm{Zn}$ and $\mathrm{Cu}$ with $\mathrm{Fe}$ is likely explained by the importance of $\mathrm{Fe}$ oxyhydroxides and sulfides as geochemical carries. In coastal environments under 
suboxic to anoxic conditions, redox reactions associated with anaerobic decomposition of organic matter via bacterial sulfate reduction produces hydrogen sulfide $\left(\mathrm{H}_{2} \mathrm{~S}\right)$, which reacts with reduced $\mathrm{Fe}$ and trace metals forming insoluble compounds. Trace metals can also interact either adsorbing or entering iron sulfides structures (amorphous-FeS, mackinawite-FeS, greigite- $\mathrm{Fe}_{3} \mathrm{~S}_{4}$, pyrrhotite $\mathrm{FeS}_{1.1}$ and pyrite- $\mathrm{FeS}_{2}$; Alongi et al., 2004; Otero and Macias, 2002; Machado et al., 2014; ) via isomorphic substitution (Huerta-Diaz and Morse, 1990; Morse and Luther, 1999). Ribeiro and coworkers (2013) analyzed acid volatile sulfides (AVS) and simultaneously-extracted metals (SEM) in surface sediments from Sepaetiba Bay, and observed a strong spatial correlation between reactive metal concentrations and sulfides. The SEM/EDS analysis performed in the sediments of Sepetiba bay show a frequent presence of pyrites (Fig.6a,b,c,d). As pyrite formation corresponds to the last stage of a sequence of reactions involving the crystallization of $\mathrm{Fe}$ sulfides, its presence is indicative of intense sediment diagenesis (Huerta-Diaz and Morse, 1990; Morse and Luther, 1999).

The T5 core (collected close to the bay connection to the sea; Fig.1) is strongly associated with elements of biogenic/marine origin, i.e. $\mathrm{Ca}, \mathrm{Mg}$. These elements are associated with precipitated inorganic carbonates or biogenic carbonates deposited in the sediments. The association to Mn (Fig.5A) can be explained by Mn-carbonates formed during diagenetic processes in sediments under anoxic conditions, where the Mn(IV)oxyhydroxides are reduced to $\mathrm{Mn}(\mathrm{II})$, mobilized into the pore water and precipitated posteriorly as carbonates in oxygenated marine waters (Burdige, 1993; Neumann et al., 2002; Emerson and Hedges, 2004;). The precipitation of Mn-oxides or carbonates can scavenge trace metals dissolved in the water column (Singh et al.1984; Burdige, 1993) and hence, could explain the association of $\mathrm{Ni}$ and $\mathrm{Cr}$ with $\mathrm{Mn}, \mathrm{Ca}$ and $\mathrm{Mg}$ in the PC1.

Phosphorus is correlated to PC1 and PC2 components due to its dual origin from anthropogenic sources (e.g, domestic wastes, industrial effluents and farming activities) and natural processes related to the weathering of rocks and vegetation and biomass organic matter (Rodrigues et al., 2009).

\subsection{Deciphering $\mathrm{Zn}$ isotopic signatures in the coastal system: mixing sources or/and biogeochemical processes during sediment transport and diagenesis?}

In this section, we combine the $\mathrm{Zn}$ isotope signatures with the main finding of PCA analysis. Each one of terrestrial, anthropogenic and marine sources implied by the PCA 
analysis can be associated to the respective representative SPM samples: (i) the terrestrial material brought to the bay by the San Francisco and Gandu rivers with $\delta^{66} \mathrm{Zn}_{\mathrm{JMC}}$ values of $+0.27 \pm 0.11 \%$ o $(2 \sigma)$; (ii) the contaminant waste transported by the creek that cross the Saco do Engenho's mangrove, characterized by $\delta^{66} \mathrm{Zn}_{\mathrm{JMC}}$ values of $+0.84 \pm 0.07 \%$ o $(2 \sigma)$; and (iii) the oceanic material that enters the bay from the west, characterized by $\delta^{66} \mathrm{Zn}_{\mathrm{JMC}}$ values of $+0.45 \pm 0.03 \%$ o $(2 \sigma)$. The distinct $\mathrm{Zn}$ isotopic signatures of each end members enable us to identify and quantify the contribution of each one in a tertiary system of mixing.

Figure 3B is showing $\delta^{66} \mathrm{Zn}_{\mathrm{JMC}}$ vs $\mathrm{Zn}(\mathrm{EF})$ plot from core T3 in the São Francisco estuary. We find that the isotope signatures plot on a straight line between the granite rocks and the metallurgic impacted sediments of Saco do Engenho, suggesting binary mixture between the anthropogenic and terrestrial end members, respectively. This is in line with the trends observed in the PCA analysis, where T1, T2, T3 and T5 cores showed a gradient encompassing sediments with geochemical composition associated to the metallurgic wastes (T1 core, $\mathrm{Zn}$ and $\mathrm{Cu}$; Fig.5B) and terrestrially-derived elements (T2 core, Si, Ti and K; Fig. 5B). The match between the linear coefficient values of $+0.24 \%$ o obtained in the linear regression of T3 core subsamples with the $\delta^{66} \mathrm{Zn}_{\text {JMC }}$ value of $+0.21 \%$ of granite rocks also supports the isotopic mixing assumption (Fig.3B). Thus, both $\mathrm{Zn}$ isotopic signatures and PCA analysis of T3 core indicate the dominance of terrestrial and metallurgic waste materials close the northeastern shore. The marine contributions are negligible in these areas, with a stronger influence in the west and outside of the bay (Barcellos et al., 1997). According to our PCA analysis, marine contributions were relevant only the T5 core, situated close the open sea (Fig.5B).

The isotope signatures found in cores T4 and T5 (located further away from old metallurgic zone, Fig.1) deviate from the trend observed to the T3 core, not aligning with granite rock isotope compositions or marine carbonates(Fig.3A and 3B). This deviation is possibly because of (i) isotopic fractionation during the particles transport along the bay, and or (ii) post-depositional processes posterior the settling in bottom sediments; and/or (iii) influence of additional sources influence the isotopic compositions in the region south of the bay. With respect to the first mechanism, $\mathrm{Zn}$ isotopic fractionation may be associated to the chemical modifications of particles promoted by the successive resuspension events in the shallow and turbulent waters of Sepetiba bay (Barcellos et al., 1997), or due diagenetic processes involving the formation and dissolution of metalbearing geochemical phases (such as metal oxides and sulfides). For example, re- 
suspension and seaward transport of sediments can expose the associated metals to conditions more oxidizing and saline, accelerating the desorption of metals due ionic strength increasing (Turner, 1996; Windom et al., 1999), or sulphide and organic matter oxidation (Zwoslman et al., 1997; Martino et al., 2002; Hatje et al., 2003; Egleton et al., 2008). Further, diagenetic processes can induce the release of metals to interstitial waters, allowing their incorporation in authigenic solid compounds (e.g., metal sulfides). All these biogeochemical processes could lead to changes of the $\mathrm{Zn}$ speciation, coordination number and bond lengths, affecting significantly the $\mathrm{Zn}$ isotopes distribution between the solution and particles (Pokrovisky et al., 2005; Aucour et al., 2011; Jouvin et al., 2011; Julliot et al., 2011). However, the proportion of $\mathrm{Zn}$ released of contaminated sediments of Sepetiba during laboratory resuspensions (Maddock et al., 2007) or Zn content typically present in the pore water during diagenesis of coastal sediments are very low (below $1 \mu \mathrm{g} . \mathrm{ml}^{-1}$, Sakelari et al., 2011; Gieskes et al., 2015). Moreover, Zn concentrations in pore water tends to decrease in the presence of AVS (Huerta-Diaz and Morse, 1992). Analysis of $\mathrm{Zn}$ concentrations in water of Sepetiba bay also indicate low concentrations compared with the particulate pool $(<0.1 \%$, Costa et al., 2005). Thus, considering the mass balance of the partition of $\mathrm{Zn}$ in the sediment and in the dissolved phase, we suggest that biogeochemical processes typically operating in estuaries probably are not enough to change the isotope compositions of $\mathrm{Zn}$ in the sediments.

With respect to the second proposed mechanism, additional sources could be attributed to the detritus of algae biomass as observed in zones of T4 and T5 cores as result of a major primary activity induced by nutrient-enrich effluents released of urban channels of Sepetiba bay (Rodrigues et al., 2012). At high discharge events on the humid summer season, the sediment plume become more enriched in nutrients (as $\mathrm{N}$ and $\mathrm{P}$ ) leading to increasing of the fertilization and chlorophyll-a in the inner part of the bay (Rodrigues et al., 2012). The algal biomass includes diatoms and other microorganism with high superficial charge which tend to be enriched in the heavy isotope (Gélabert et al., 2008; Coutaud et al., 2014).

Other probable additional source affecting the $\mathrm{Zn}$ isotopic compositions could be associated to diffuse urban pollution linked to the intense urban sprawl and industrial development in the watershed of Sepetiba bay initiated in the 1970's (Molisani et al., 2004). The $\delta^{66} \mathrm{Zn}_{\mathrm{JMC}}$ values of common urban anthropogenic sources, such as tire wear (+0.04 $\pm 0.2 \%$, Thapalia et al., 2010), vehicle emission ( -0.87 to +0.07 , Gioia et al., 2008), urban runoff (from +0.13 to $+0.15 \%$, Chen et al., 2009) and wastewaters and sludge 
$(+0.08$ to $+0.31 \%$, Chen et al., 2009) are in agreement with the high EF and lighter isotopic signatures in the T4 and T5 cores when compared with T3 core. Thus, we hypothesize that a third and unknown $\mathrm{Zn}$ endmember, probably associated to diffuse sources present in the Sepetiba bay watershed, such as sewage and/or industrial effluents, affects the $\mathrm{Zn}$ isotope compositions of T4 and T5 cores. Therefore, we suggest that while in the northeastern area of the bay the observed $\mathrm{Zn}$ isotope compositions are derived from binary mixing of metallurgic and natural terrestrial sources, this third endmember explains the isotopic signature difference observed in the southeastern and southern areas of the bay. The mixing source model is represented graphically in the Fig.7.

\subsection{Tracing $\mathrm{Zn}$ contamination in mangrove sediments using stable isotope composition}

Mangroves ecosystems play an important role in the dynamics of contaminants across the boundaries of terrestrial and coastal areas, receiving, trapping and exporting contaminants (Machado and Lacerda, 2004). The balance between inputs and outputs of metals in the mangroves determine its function as sources or sinks (Lacerda et al., 1988; Alongi et al., 2004)

In Sepetiba bay, the water circulation controlled by tides and surface currents tends to create a preferential deposition of sediments along the mangroves located at the shore (Roncarati and Carelli, 2012; Leal Neto et al., 2006), where metal contaminants (including $\mathrm{Zn}$ ) are trapped on organic and sulfide-rich sediments that make the mangrove ecosystems from our study area important sinks of metal contaminants (Lacerda et al., 1993; Wasserman et al., 2001; Machado et al., 2008). If the $\mathrm{Zn}$ isotopic signatures of the SPM brought during the tidal cycles to the mangrove sediment remain well preserved after deposition and are not significantly altered by biogeochemical processes, past sources and the fate of the $\mathrm{Zn}$ contamination can be reconstructed.

The $\delta^{66} \mathrm{Zn}_{\mathrm{JMC}}$ values between the top layers of the mudflat cores and the respective superficial mangrove sediments are very similar in the Saco do Engenho, i.e. $+0.83 \%$ for the first layer of the core $\mathrm{T} 2$ and $+0.82 \%$ (average) for the surface mangrove sediments. In the São Francisco Channel, it was observed a value of $+0.46 \%$ for the first layer of core $\mathrm{T} 3$ and $+0.47 \%$ (average) for the surface mangrove sediments. The overlap of the isotope signature between the sediment particles of mud flat and mangrove stations is in 
line with the lack of significant $\mathrm{Zn}$ isotopic fractionation during the SPM transport in the estuarine system as discussed in section 5.2, and evidence little or no post-depositional alterations of $\mathrm{Zn}$ isotopic signatures, at least in the superficial layers. However, in the mangrove core (T1 core) the $\delta^{66} \mathrm{Zn}$ values and $\mathrm{Zn}$ EF (Fig.3B) are not significantly correlated, contrasting with the good correlations of $\delta^{66} \mathrm{Zn}$ values with $\mathrm{Zn}$ EF observed for all other cores. This contrast suggests that the $\mathrm{Zn}$ isotopic record is less preserved in mangrove sediments.

The good isotopic record preservation of mud flat cores can be explained by the more stable redox conditions in these sediments, since bioturbation and vegetation influence are limited. Moreover, except for T4 core, the mud flat cores are in subtidal zone, constantly waterlogged, and therefore, not exposed to open air during tidal cycles. The Fe/Mn ratios in the mud flat cores (T2, T3, T4, T5 cores, Fig.2) suggest moderate variations in redox state, leading to reduced elemental remobilization trigged by redox conditions (Fig.2) and a preservation of the geochemical records. The ${ }^{210} \mathrm{~Pb}$ profiles of dated sediments of Sepetiba bay and their consistence with temporal changes of $\mathrm{Zn}$ and $\mathrm{Cd}$ concentrations during the beginning of industrialization and metallurgic impacts of the bay, are strong evidences for preservation of the geochemical records in the mud flats (Molisani et al., 2004; Marques et al., 2006; Gomes et al., 2009; Patchineelam et al., 2011). The studies of ${ }^{210} \mathrm{~Pb}$ have also demonstrated that sediment remobilization (probably due to bioturbation) is restricted to the first $10 \mathrm{~cm}$. Such findings agree well with the variations of $\mathrm{Fe} / \mathrm{Mn}$ ratios found on the top profiles of the mud flat sediments obtained in this study (Fig.2).

The mangrove environment, however, may present more intense biogeochemical changes due to combined influences of tidal hydrodynamics, plants and bioturbation. In the core T1 (Saco do Engenho), large variations in the Fe/Mn (Fig. 2) and trace elements profiles (Appendices A) indicate remobilization of elements possibly promoted by these combined influences. During the high tide, sediments are waterlogged, promoting the Feoxyhydroxides reduction and the formation of insoluble iron and trace elements sulfides by the microbial activity (Huerta-Diaz and Morse, 1992; Andrade et al., 2012). In turn, insoluble sulfide phases are oxidized during low tides and by $\mathrm{O}_{2}$ release in the rhizospheres (Lacerda et al., 1993; Purnobasuki and Suzuki, 2005; Marchand et al., 2011; Machado et al., 2014), leading to precipitation of Fe-oxyhydroxides and formation of iron plaques around root surfaces (Lacerda et al., 1993; Otte et al., 1995; Zhou et al., 2011). While oxidation of sulfides and reduction of Fe minerals may increase the mobility of 
trace elements, the precipitation of Fe-oxyhydroxides tends to decrease this mobility, limiting their transport and bioavailability for the plant uptake (Lacerda et al., 1993; Clark et al., 1998; Machado et al., 2005; Zhou et al., 2011). These continuous geochemical processes of releasing and immobilization involving $\mathrm{Zn}$ on the different Fe-minerals phases can result in significant isotopic fractionation post deposition within mangrove sediments. Experimental works appoint that the mineral surfaces tend to be enriched in the heavy isotope compared with the solution phase (Pokrovisky et al., 2005; Baliestri et al., 2008; Juillot et al., 2008). Moreover, in marine waters, the formation of $\mathrm{Zn}$-chloride complexes enriched in the light isotope likely increase the factor of fraction $(\Delta)$ between the particulate and dissolved phase (Bryan et al., 2015). In the sulfidic phase, the light $\mathrm{Zn}$ isotope seems be incorporated preferentially (Wilkinson et al., 2005; John et al., 2008; Veeramani et al., 2015). Thus, the preferential retention of the heavy isotope in the Feoxyhydroxides and the loss of light isotope to pore waters during oxidation of sulfides or reduction of Fe-minerals could explain the heaviest isotope compositions of $\mathrm{Zn}$ (above $1.0 \%$ ) found in the mangrove core (T1). Similarly to urban wetlands, soils and peat bogs systems, $\mathrm{Zn}$ isotopic signatures of mangroves seem be affect by post deposition processes (Weiss et al., 2007; Julliot et al., 2011; Aucour et al., 2015). A scheme summarizing our main findings are presented at Fig.7.

\subsection{Effects of anthropogenic contamination on $\mathrm{Zn}$ isotope compositions of mangrove} tree leaves

The $\mathrm{Zn}$ concentrations of leaves of Laguncularia racemosa increases with the degree of $\mathrm{Zn}$ contamination observed in the mangrove surface sediments (Fig.4A). This indicates that the inputs of anthropogenic $\mathrm{Zn}$ increased the bioaccumulation of this element in leaf tissues. However, the BSAF of the leaves shows an inverse correlation with the sediment $\mathrm{Zn}$ loading (Fig.4B), appointing that the substantial excess of anthropogenic $\mathrm{Zn}$ in the sediments of the station MSE (highly impacted by the metallurgic wastes) in comparison to MSENS and MSF does not reflect a proportional increasing in the $\mathrm{Zn}$ incorporation by mangrove leaves. An EF above 100-fold is noticed between the $\mathrm{Zn}$ concentrations in sediments of MSE and MSF stations, while the BSAF for leaves is slightly more than 3fold.

The results agree with the previously observed trends that leaves BSAF for $\mathrm{Zn}$ and other essential metals decrease as environmental concentrations increase (MacFarlane et 
al., 2007). This is linked to the capability of the mangroves sediments to reduce metal bioavailability due to the formation of stable metal sulfides, metal-organic matter complexes and metal-retention in clays minerals and in Fe-oxyhidroxide plaques on the roots (Machado et al., 2002; Marchand et al., 2006; MacFarlane et al., 2007; Marchand et al., 2011; Lewis et al., 2011). A second control is the activation of tolerance mechanisms of mangroves plants under toxic environments, including excretion of elements through leaves or roots (Macfarlane and Burchett, 1999; MacFarlane and Buchett, 2000; MacFarlane and Burchett, 2002; Naido et al., 2014) and limited translocation of elements from roots to aboveground tissues. These mechanisms may involve metal apoplastic association to cell walls and intracellular association to metalbinding compounds and subcellular compartmentation of excess metals into vacuoles (MacFarlane and Buchett, 2000; MacFarlane et al., 2007).

The leaves of Laguncularia racemosa show $\delta^{66} \mathrm{Zn}_{\mathrm{JMC}}$ values between +0.07 and $+0.25 \%$ and large fractionation in relation to the sediments $\left(\Delta_{\text {plant-sediment }}\right)$, ranging from 0.73 to $-0.24 \%$. These results evidence a strong biological $\mathrm{Zn}$ isotopic fractionation by mangrove trees. Previous studies have demonstrated significant $\mathrm{Zn}$ isotope fractionation during uptake, translocation and distribution between the internal compartments (Weiss et al., 2004; Viers et al., 2007; Moynier et al., 2009; Arnold et al., 2010; Caldelas et al., 2011; Jouvin et al., 2012; Arnold et al., 2015). These processes may be dependent on plant uptake strategies, concentration, speciation, transpiration flow and height (Weiss et al., 2004; Moynier et al., 2009; Arnold et al., 2010; Jouvin et al., 2012; Caldelas et al., 2011; Couder et al., 2015: Arnold et al., 2015). For example, isotope fractionation of zinc during uptake across the root cell membrane have been associated with preferential incorporation of the light isotope if controlled by diffusion, while preferential uptake of the heavy isotope occurs via $\mathrm{Zn}$ complexation with phytosiderophores and carriermediated transport (e.g., Zn/Fe-regulated protein, ZIP) (Jouvin et al., 2012). The preferential heavy $\mathrm{Zn}$ isotope sorption on surface walls of roots also contribute to the final isotopic balance between the nutritive solution and the plant (Weiss et al., 2004; Jouvin et al., 2012).

Possible intra-specific variability related to strategies of Zn uptake and internal translocation from roots to shoots and leaves may influence the observed results. However, a single species was collected and leaves were collected at similar heights to improve comparability, and the variable $\Delta_{\text {plant-sediment }}$ values found between the mangrove stations indicates that the observed isotopic fractionation magnitude is controlled by 
external factors. The strong correlations observed between the $\Delta_{\text {plant-sediment }}$ and BSAF values and $\mathrm{Zn}$ concentrations of sediments (Fig.4C) suggest the degree of $\mathrm{Zn}$ contamination of sediments as the major factor affecting $\mathrm{Zn}$ isotope signatures of leaves. Our data suggests that mangrove trees affected by the electroplating wastes likely employ tolerance mechanisms, as discussed above. The binding of $\mathrm{Zn}$ by carrier-proteins or other ligands for immobilization or $\mathrm{Zn}$ adsorption onto cell walls can lead to the preferential retention of heavy isotopes. These mechanisms imply in enrichment of the light isotope in the $\mathrm{Zn}$ pool translocated to aerial plant compartments, including leaves tissues. This contribute to explains the lower BSAF value in the most contaminated mangrove station and the lighter isotopic compositions in the leaves (Fig.4B and C). In opposition, areas with low concentrations of micronutrients such as $\mathrm{Zn}$ may induce the translocation from roots to shoots and leaves by an active transport of this element chelated to organic molecules or bound to carrier-transport proteins to supply nutritional demands (MacFarlane and Burchett 2000; 2002), leading to a preferential transport of the heavy isotope. These physiological responses may contribute to explain the heavier isotope compositions found in the leaves of MSF station.

Previous studies have observed changes in the $\mathrm{Zn}$ isotope signature patterns in plants depending on Zn supply. Caldelas et al. (2010) performing experiments with wet plants in substrates with toxic levels of $\mathrm{Zn}$, observed heavier isotopic compositions in roots than in leaves compared with that found under sufficient $\mathrm{Zn}$ concentrations. These results were interpreted as consequences of the processes of chelation and compartmentation preferential of the heavy isotope of $\mathrm{Zn}$ excess in the roots, leading to a translocation of the lighter isotopic $\mathrm{Zn}$ pool to aerial tissues. These results were consistent with the pattern of $\mathrm{Zn}$ isotope compositions of plants grown in soils contaminated by metallurgic waste (Couder et al., 2016). Arnold et al. (2010) found contrasting isotopic fractionation mechanisms between plants grown in soils enriched in $\mathrm{Zn}$ (with fertilizer) and soils deficient in $\mathrm{Zn}$ (without fertilizer). In the latter case, the association of $\mathrm{Zn}$ to complexing substances released from the roots and the uptake of complexed $\mathrm{Zn}$ by specific carriers in roots implied in heavier isotopic compositions. Our interpretation on the systematics of $\mathrm{Zn}$ isotopic signatures from leaves under high and low environmental exposure to $\mathrm{Zn}$ fits well to the interpretation of laboratorial experiments (Arnold et al., 2010; Caldelas et al., 2010; Weiss et al., 2014). 


\subsection{Quantifying the anthropogenic $\mathrm{Zn}$ inputs in the past and present days}

\subsubsection{The Zn isotope signatures of electroplating wastes}

Cores T1 and T2, superficial sediments and SPM samples collected close to the mangrove impacted by the old tailing wastes (Saco do Engenho) show high Zn concentrations and an heavier isotopic composition ( $\delta^{66} \mathrm{Zn}_{\mathrm{JMC}}$ values ranging from +0.68 to $+1.15 \%$ ). These $\delta^{66} \mathrm{Zn}_{\text {JMC }}$ values are largely different from the geological background of Sepetiba bay, as represented by granites rocks $(+0.21 \pm 0.01 \%, 2 \sigma, n=2)$ and from the average of global crust $\left(+0.28 \pm 0.05 \%\right.$, Chen et al. 2013). These heavy $\delta^{66} \mathrm{Zn}$ values reflect the isotopic fractionation during eletroctoplating process, which tends to produce wastes enriched in the heavy isotope (Kavner et al., 2006) and agrees with Zn signatures of wastes and polluted sediments by metallurgical processes (Sivry et al., 2008; Juilliot et al., 2011). The isotopic signatures of sediments from Saco do Engenho indicate a large fractionation factor associated to the electroplating process, in relation to the signatures of willemite ores (average of $+0.03 \pm 0.24 \%$ ). This is coherent with the fractionation factor found by

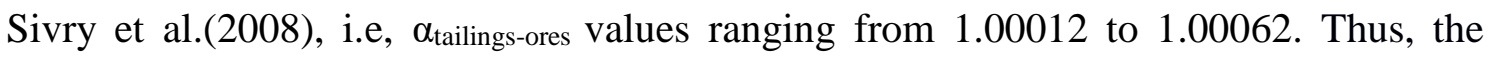
average of $\delta^{66} \mathrm{Zn}_{\text {JMC }}$ values of these samples of $+0.86 \pm 0.15 \%$ represents the best estimate for the isotopic signature of the electroplating wastes.

\subsubsection{Zinc isotope signature of natural terrestrial sources}

The base of the T3 core (i.e., $45-55 \mathrm{~cm}$ depth) have EF values $\leq 2$ and are likely representative of the terrestrial background source. To improve the characterization of the this terrestrial source, we analyzed granites rock from the region and the average $\delta^{66} \mathrm{Zn}_{\mathrm{JMC}}$ value for granite rock and the base profile samples of T3 core yield a value of +0.28 $\pm 0.12 \%$ o $(2 \sigma, n=3)$. This range is close to the bulk Earth zinc isotopic composition of $+0.28 \pm 0.05 \%$ (Chen et al., 2013), marine sediments ( $+0.23 \pm 0.08 \%$ o, 2 $\sigma, n=20$ Maréchal et al., 2000) and sapropels (0.28 $\pm 0.02 \%, 2 \sigma, n=3$, Maréchal et al., 2000) and regional backgrounds from areas such as the Lot Watershed (France) $\left(\delta^{66} \mathrm{Zn}_{\mathrm{JMC}}=+0.31 \pm 0.04 \%\right.$ o $(2 \sigma), n=4$, Sivry et al., 2008) and Lommel (Belgium) $\left(\delta^{66} \mathrm{Zn}_{\mathrm{JMC}}=+0.31 \pm 0.09(2 \sigma), n=4\right.$, Sonke et al., 2008). 


\subsubsection{Quantifying past and present anthropogenic inputs}

In the previous sections, three main end-members were identified for $\mathrm{Zn}$ : (i) the major anthropogenic source (represented by the major electroplating wastes), (ii) natural terrestrial sources (represented by the signatures of granites and sediments from the basis of core T3), and (iii) marine natural sources. A fourth source related to diffuse pollution sources derived from the drainage basin is also suspected (section 5.2), however, since the sediment samples of Sepetiba bay plot are dominated by the two the first major sources, a simplification for a binary mixture model can be used to quantify the relative contribution from the major anthropogenic $\mathrm{Zn}$ source, according to the equation below:

$$
Z n_{\text {anthr. } \%}=\left(\frac{\delta_{\text {sample }}-\delta_{\text {terrestrial }}}{\delta_{\text {anthropogenic }}-\delta_{\text {terrestrial }}}\right) * 100 \quad \text { eq. } 2 \text {, }
$$

The Fig. 8 shows the $\mathrm{Zn}_{\text {anth.\% }}$ estimated for cores T3, T4 and T5. Since cores $\mathrm{T} 1$ and $\mathrm{T} 2$ represent the isotopic composition essentially from the anthropogenic end member, they were not considered in the mixing model. Clear evolution from a period without significant contribution from electroplating wastes discharge into the bay (with low

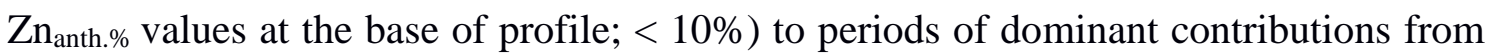
this source were observed in the profile T3. For the core T4, however, only high contributions from the major anthropogenic $\mathrm{Zn}$ source were found $\left(\mathrm{Zn}_{\text {anth.\% }} \geq 70 \%\right.$ ), which indicates that only the post-industrialization period was recorded. In the core T5,

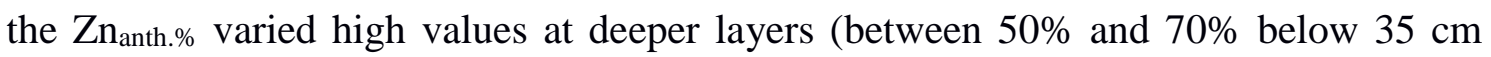
depth) and a tendency of decreasing above $25 \mathrm{~cm}$ depth, reaching the lowest $\mathrm{Zn}_{\text {anth.\% }}$ value of $14 \%$. As discussed above (section 5.2), possible contributions from diffuse sources may have also affected the results from cores $\mathrm{T} 4$ and $\mathrm{T} 5$, leading to lighter isotope compositions. Therefore, this may imply in some underestimation of the percentage of anthropogenic $\mathrm{Zn}$ related to electroplating wastes. Previous works have confirmed the significant changes in $\mathrm{Zn}$ concentrations in dated cores from Sepetiba Bay, corresponding to the 1960s and 1970s, in agreement with the beginning of the electroplating plant influence (Molisani et al., 2004; Marques et al., 2006; Gomes et al., 2009; Patchineelam

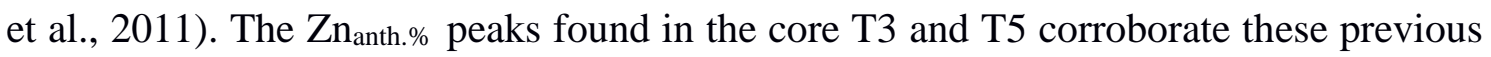
observations, as attested by the isotopic source signature assessment. Another important feature of both cores T3 and T5 is that the observed Zn EF in uppermost layers (Fig.2) was associated to a diminished relative contribution from the major industrial source 
(Fig.8). This evidences an attenuation of the total $\mathrm{Zn}$ input from electroplating wastes to the bay. The $\mathrm{Zn}$ isotopic characterization of diffuse sources will be useful to dimension their relative contributions face to the continuous declining of the metallurgic point source influence. Thus, the temporal and spatial $\mathrm{Zn}$ isotopes signature variability allows to verify the degree of the impacts of the electroplating activity and can be an important tool for futures monitoring in Sepetiba bay as well coastal areas worldwide.

\section{CONCLUSIONS}

The zinc isotopic compositions of sediment samples and SPM collected in the Sepetiba bay, Rio de Janeiro, Brazil, and of willemite ores, show significant variation of $\delta^{66} \mathrm{Zn}_{\mathrm{JMC}}$ values $(-0.01$ to $+1.15 \%)$. The main conclusions derived from these results are:

- The $\mathrm{Zn}$ isotopic composition of sediments are well explained by a mixing model, including three source end member, i.e. terrestrial background, marine and anthropogenic, this last represented by the electroplating wastes.

- The sediment cores collected in the mud flat of the bay showed good correlation between $\delta^{66} \mathrm{Zn}$ values and $\mathrm{Zn}$ enrichment factors, indicating the $\mathrm{Zn}$ isotopes as effective tracer of past and present metallurgical impacts, since the record of this source is well preserved in the sediments. The other sediment cores, however, located away from the contamination hot spot, have been likely affected by additional sources such as diffuse pollution associated to sewage and other industrial effluents.

- In mangrove forests, the $\mathrm{Zn}$ isotopic compositions of superficial sediments seems to preserve the isotopic compositions of the sources. However, the isotopic signature of the electroplating wastes is slightly modified at specific depths of the profile, due the biogeochemical processes triggered by tidal cycles, bioturbation and rhizosphere processes.

- Sediment and SPM samples collected close to the old metallurgical impacted zone in the Saco do Engenho creek showed the highest concentrations and the heaviest isotopic compositions. The estimated $\delta^{66} \mathrm{Zn}_{\mathrm{JMC}}$ value representative for metallurgical wastes was $+0.86 \pm 0.15 \%$ o $(2 \sigma)$. Willemite ores have lighter compositions ( -0.1 to $0.14 \%$ ) indicating a significant fractionation induced by electroplating processes, favoring the enrichment of heavy isotopes in the wastes. 
- The $\delta^{66} \mathrm{Zn}_{\mathrm{JMC}}$ for the terrestrial source was constrained to $+0.28 \pm 0.12 \%$ o using the pre-industrial record of the sediment cores and rocks representative of the local geology.

- Negligible contributions of marine sources and the dominance of terrestrial and major anthropogenic sources in the inner bay, allowed the application of a binary mixing model to quantify relative contributions from these sources. The calculations suggest contributions of anthropogenic $\mathrm{Zn}$ ranging from negligible values, during the preindustrial period, up to $80 \%$ during the industrial period. The relative contribution of the major anthropogenic source of $\mathrm{Zn}$ has decreased in some specific regions of the bay, after the end of metallurgical activities in 1998.

- Low Zn biota-sediment accumulation factors (BSAF < 0.1) and isotopic signatures ranging between +0.07 and $+0.25 \%$ were found for leaves of the mangrove stations sampled. Isotopic fractionation between mangrove leaves and sediments (expressed using $\Delta_{\text {plant-sediment }}$ ) varied between -0.73 to $-0.25 \%$ and was negatively correlated to the $\mathrm{Zn}$ sediment concentrations, suggesting that high $\mathrm{Zn}$ contaminated sites trigger tolerance mechanisms of mangrove's trees, inducing different $\mathrm{Zn}$ isotopic pattern from leaves collected in sites with low contamination.

- Zinc isotopes successfully trace spatial and temporal variations in source contributions of metallurgical wastes in a complex ecosystem such as a coastal area, confirming previous finding that $\mathrm{Zn}$ isotopes are an effecting tracer of anthropogenic sources in the environment.

\section{Acknowledges}

The authors acknowledge the financial support and grants provided by CNPq (Brazilian Research Council, grant numbers: 161944/2012-4 and 211238/2014-7), the laboratorial support from Erico Zacchi, Bárbara Alcâtara, Jeane Chaves, Myller Tonhá and Fernando Cavalcante, and the suggestions and commentaries from Prof. Jeremie Garnier.

\section{References}

Adriano D. and Adriano D. (2001) Trace elements in terrestrial environments. Springer, New York.

Alongi D., Wattayakorn G., Boyle S., Tirendi F., Payn C. and Dixon P. (2004) Influence of roots and climate on mineral and trace element storage and flux in tropical mangrove soils. Biogeochemistry 
69, $105-123$.

Amado Filho G., Andrade L., Karez C., Farina M. and Pfeiffer W. (1999) Brown algae species as biomonitors of $\mathrm{Zn}$ and $\mathrm{Cd}$ at Sepetiba Bay, Rio de Janeiro, Brazil. Mar. Environ. Res. 48, 213-224.

Andrade R., Sanders C., Boaventura G. and Patchineelam S. (2012) Pyritization of trace metals in mangrove sediments. Environ. Earth. Sci. 67, 1757-1762.

Araújo D., Boaventura G., Viers J., Mulholland D., Weiss D., Araújo D., Lima B., Ruiz I., Machado W., Babinski M. and Dantas E. (2016) Ion Exchange Chromatography and Mass Bias Correction for Accurate and Precise Zn Isotope Ratio Measurements in Environmental Reference Materials by MCICP-MS. J. Brazil. Chem. Soc. 00, 00, 1-11

Archer C. and Vance D. (2004) Mass discrimination correction in multiple-collector plasma source mass spectrometry: an example using $\mathrm{Cu}$ and $\mathrm{Zn}$ isotopes. J. Anal. Atom. Spectrom. 19, 656.

Arnot J. and Gobas F. (2006) A review of bioconcentration factor (BCF) and bioaccumulation factor (BAF) assessments for organic chemicals in aquatic organisms. Environ. Rev. 14, 257-297.

Arnold T., Kirk G., Wissuwa M., Frei M., Zhao F., Mason T. And Weiss D. (2010) Evidence for the mechanisms of zinc uptake by rice using isotope fractionation. Plant. Cell. Environ. 33, 370-381.

Arnold T., Markovic T., Kirk G., Schönbächler M., Rehkämper M., Zhao F. and Weiss D. (2015) Iron and zinc isotope fractionation during uptake and translocation in rice (Oryza sativa) grown in oxic and anoxic soils. C. R. Geosci. 347, 397-404.

Aucour A., Bedell J., Queyron M., Magnin V., Testemale D. and Sarret G. (2015) Dynamics of Zn in an urban wetland soil-plant system: Coupling isotopic and EXAFS approaches. Geochim. Cosmochim. Ac. 160, 55-69.

Balistrieri L., Borrok D., Wanty R. and Ridley W. (2008) Fractionation of $\mathrm{Cu}$ and $\mathrm{Zn}$ isotopes during adsorption onto amorphous $\mathrm{Fe}(\mathrm{III})$ oxyhydroxide: Experimental mixing of acid rock drainage and ambient river water. Geochim. Cosmochim. Ac. 72, 311-328.

Barcellos C. and Lacerda L. (1994) Cadmium and zinc source assessment in the Sepetiba Bay and basin region. Environm. Monit. Assess. 29, 183-199.

Barcellos C., Lacerda L. and Ceradini S. (1997) Sediment origin and budget in Sepetiba Bay (Brazil) - an approach based on multielemental analysis. Environm. Geol. 32, 203-209.

Barcellos C., Rezende C. and Pfeiffer W. (1991) Zn and Cd production and pollution in a Brazilian coastal region. Marine Pollut. Bull. 22, 558-561.

Barcellos C., Lacerda L.D., Rezende C.E. and Machado J. (1992) Arsenic contamination in a coastal environment affected by a zinc smelting plant (Sepetiba Bay, Brazil). In: Proceedings of the International Seminar on Arsenic in the Environment its Incidence and Health, Universidad de Chile, Santiago, pp. 59-62.

Barone R.H.T.(1973) Perfil analítico do zinco. Ministério das Minas e Energia. Departamento Nacional da Produçao Mineral. Bolteim nº26. Rio de Janeiro, Brasil.

Borrok D., Gieré R., Ren M. and Landa E. (2010) Zinc Isotopic Composition of Particulate Matter Generated during the Combustion of Coal and Coal + Tire-Derived Fuels. Environ. Sci. Tech. 44, 9219-9224.

Bryan A., Dong S., Wilkes E. and Wasylenki L. (2015) Zinc isotope fractionation during adsorption onto Mn oxyhydroxide at low and high ionic strength. Geochim. Cosmochim. Ac. 157, 182-197.

Burdige D. (1993) The biogeochemistry of manganese and iron reduction in marine sediments. Earth Sci. Rev. 35, 249-284.

Caldelas C., Dong S., Araus J. and Jakob Weiss D. (2010) Zinc isotopic fractionation in Phragmites australis in response to toxic levels of zinc. J. Exp. Bot. 62, 2169-2178.

Chen J., Gaillardet J. and Louvat P. (2008) Zinc Isotopes in the Seine River Waters, France: A Probe of Anthropogenic Contamination. Environ. Sci. Technol. 42, 6494-6501.

Chen J., Gaillardet J., Louvat P. and Huon S. (2009) Zn isotopes in the suspended load of the Seine River, France: Isotopic variations and source determination. Geochim. Cosmochim. Ac. 73, 4060-4076.

Chen H., Savage P., Teng F., Helz R. and Moynier F. (2013) Zinc isotope fractionation during magmatic differentiation and the isotopic composition of the bulk Earth. Earth Planet. Sci. Letters. 369-370, 34-42. 
Clark J. (1996) Coastal zone management handbook. CRC Press, Boca Raton, Fla.

Clark M., McConchie D., Lewis D. and Saenger P. (1998) Redox stratification and heavy metal partitioning in Avicennia-dominated mangrove sediments: a geochemical model. Chem. Geol. 149, 147-171.

Cloquet C., Carignan J., Lehmann M. and Vanhaecke F. (2007) Variation in the isotopic composition of zinc in the natural environment and the use of zinc isotopes in biogeosciences: a review. Anal. Bioanal. Chem. 390, 451-463.

Costa A., Anjos M., Lopes R., Pérez C. and Castro C. (2005) Multi-element analysis of sea water from Sepetiba Bay, Brazil, by total reflection x-ray fluorescence spectrometry using synchrotron radiation. X-Ray Spectrom. 34, 183-188.

Couder E., Mattielli N., Drouet T., Smolders E., Delvaux B., Iserentant A., Meeus C., Maerschalk C., Opfergelt S. and Houben D. (2015) Transpiration flow controls Zn transport in Brassica napus and Lolium multiflorum under toxic levels as evidenced from isotopic fractionation. C. R. Geosci. 347, 386-396.

Coutaud A., Meheut M., Viers J., Rols J. and Pokrovsky O. (2014) Zn isotope fractionation during interaction with phototrophic biofilm. Chem. Geol. 390, 46-60.

Dolgopolova A., Weiss D., Seltmann R., Kober B., Mason T., Coles B. and Stanley C. (2006) Use of isotope ratios to assess sources of $\mathrm{Pb}$ and $\mathrm{Zn}$ dispersed in the environment during mining and ore processing within the Orlovka-Spokoinoe mining site (Russia). Appl. Geochem. 21, 563-579.

Du Laing G., Rinklebe J., Vandecasteele B., Meers E. and Tack F. (2009) Trace metal behaviour in estuarine and riverine floodplain soils and sediments: A review. Sc. Total Environ 407, 3972-3985.

Eggleton J. and Thomas K. (2004) A review of factors affecting the release and bioavailability of contaminants during sediment disturbance events. Environ. Int. 30, 973-980.

Emerson, S., and Hedges, J. (2004). Sediment diagenesis and benthic flux. In: Treatise on Geochemistry (eds, H. Holland and K. Turekian). Elsevier, Amsterdam. pp. 293-319.

Gieskes J., Han S., Rathburn A., Rothwell G., Pérez M., Porrachia M., Barbanti A. and Deheyn D. (2015) Anthropogenic contaminants in Venice Lagoon sediments and their pore fluids: Results from the SIOSED Project. Mar. Chem. 174, 73-84.

Gélabert A., Pokrovsky O., Viers J., Schott J., Boudou A. and Feurtet-Mazel A. (2006) Interaction between zinc and freshwater and marine diatom species: Surface complexation and $\mathrm{Zn}$ isotope fractionation. Geochim. Cosmochim, Ac. 70, 839-857.

Gioia S., Weiss D., Coles B., Arnold T. and Babinski M. (2008) Accurate and Precise Zinc Isotope Ratio Measurements in Urban Aerosols. Anal. Chem. 80, 9776-9780.

Gomes F. de C., Godoy J., Godoy M., Lara de Carvalho Z., Tadeu Lopes R., Sanchez-Cabeza J., Drude de Lacerda L. and Cesar Wasserman J. (2009) Metal concentrations, fluxes, inventories and chronologies in sediments from Sepetiba and Ribeira Bays: A comparative study. Mar. Pollut. Bull. 59, 123-133.

Gordon R., Graedel T., Bertram M., Fuse K., Lifset R., Rechberger H. and Spatari S. (2003) The characterization of technological zinc cycles. Res. Conserv. Rec. 39, 107-135.

Hatje V., Payne T., Hill D., McOrist G., Birch G. and Szymczak R. (2003) Kinetics of trace element uptake and release by particles in estuarine waters: effects of $\mathrm{pH}$, salinity, and particle loading. Environ. Int. 29, 619-629.

Hudson-Edwards K., Jamieson H. and Lottermoser B. (2011) Mine Wastes: Past, Present, Future. Elements 7, 375-380.

Huerta-Diaz M. and Morse J. (1992) Pyritization of trace metals in anoxic marine sediments. Geochim. Cosmochim. Ac. 56, 2681-2702.

John S., Genevieve Park J., Zhang Z. and Boyle E. (2007) The isotopic composition of some common forms of anthropogenic zinc. Chem. Geol. 245, 61-69.

John S., Rouxel O., Craddock P., Engwall A. and Boyle E. (2008) Zinc stable isotopes in seafloor hydrothermal vent fluids and chimneys. Earth Planet. Sci. Lett. 269, 17-28.

Jouvin D., Louvat P., Juillot F., Maréchal C. and Benedetti M. (2009) Zinc Isotopic Fractionation: Why Organic Matters. Environ. Sci. Technol. 43, 5747-5754.

Juillot F., Marèchal C., Morin G., Jouvin D., Cacaly S., Telouk P., Benedetti M., Ildefonse P., Sutton S., Guyot F. and Brown G. (2011) Contrasting isotopic signatures between anthropogenic and geogenic 
$\mathrm{Zn}$ and evidence for post-depositional fractionation processes in smelter-impacted soils from Northern France. Geochim. Cosmochim. Ac. 75, 2295-2308.

Kavner A., John S., Sass S. and Boyle E. (2008) Redox-driven stable isotope fractionation in transition metals: Application to Zn electroplating. Geochim. Cosmochim. Ac. 72, 1731-1741.

Kasuya M., Teranishi H., Aoshima K., Katoh T., Horigushi H., Morikawa Y., Nishijo M. and Iwata, K. (1992) Water pollution by cadmium and the onset of Itai-itai disease. Water Sci. Technol. 25, 149156.

Kelley K., Wilkinson J., Chapman J., Crowther H. and Weiss D. (2009) zinc isotopes in sphalerite from base metal deposits in the red dog district, northern Alaska. Econ. Geol. 104, 767-773.

Kossoff D., Dubbin W., Alfredsson M., Edwards S., Macklin M. and Hudson-Edwards K. (2014) Mine tailings dams: Characteristics, failure, environmental impacts, and remediation. Appl. Geochem. 51, 229-245.

Kunzmann M., Halverson G., Sossi P., Raub T., Payne J. and Kirby J. (2012) Zn isotope evidence for immediate resumption of primary productivity after snowball Earth. Geology 41, 27-30.

Lacerda L., Carvalho C., Tanizaki K., Ovalle A. and Rezende C. (1993) The Biogeochemistry and Trace Metals Distribution of Mangrove Rhizospheres. Biotropica 25, 252.

Lacerda L., Martinelli L., Rezende C., Mozeto A., Ovalle A., Victoria R., Silva C. and Nogueira F. (1988) The fate of trace metals in suspended matter in a mangrove creek during a tidal cycle. Sci. Total Environ. 75, 169-180.

Lacerda L. and Molisani M. (2006) Three decades of Cd and Zn contamination in Sepetiba Bay, SE Brazil: Evidence from the mangrove oyster Crassostraea rhizophorae. Mar. Pollut. Bull. 52, 974-977.

Lacerda L., Pfeiffer W. and Fiszman M. (1987) Heavy metal distribution, availability and fate in Sepetiba Bay, S.E. Brazil. Sci. Total Environ. 65, 163-173.

Langston W. and Bebianno M. (1998) Metal metabolism in aquatic environments. Chapman \& Hall, London.

Leal Neto A., Legey L., González-Araya M. and Jablonski S. (2006) A System Dynamics Model for the Environmental Management of the Sepetiba Bay Watershed, Brazil. Environ. Manage. 38, 879-888.

Lewis M., Pryor R. and Wilking L. (2011) Fate and effects of anthropogenic chemicals in mangrove ecosystems: A review. Environ. Pollut. 159, 2328-2346.

MacFarlane G. and Burchett M. (1999) Zinc distribution and excretion in the leaves of the grey mangrove, Avicennia marina (Forsk.) Vierh. Environ. Exp. Bot. 41, 167-175.

MacFarlane G. and Burchett M. (2000) Cellular distribution of copper, lead and zinc in the grey mangrove, Avicennia marina (Forsk.) Vierh. Aquat. Bot. 68, 45-59.

MacFarlane G. and Burchett M. (2002) Toxicity, growth and accumulation relationships of copper, lead and zinc in the grey mangrove Avicennia marina (Forsk.) Vierh. Mar. Environ. Res. 54, 65-84.

MacFarlane G., Koller C. and Blomberg S. (2007) Accumulation and partitioning of heavy metals in mangroves: A synthesis of field-based studies. Chemosphere 69, 1454-1464.

Machado W., Borrelli N., Ferreira T., Marques A., Osterrieth M. and Guizan C. (2014) Trace metal pyritization variability in response to mangrove soil aerobic and anaerobic oxidation processes. Mar. Pollut. Bull. 79, 365-370.

Machado W., Lacerda, L. (2004) Overview of the Biogeochemical Controls and Concerns with Trace Metal Accumulation in Mangrove Sediments. In: Environmental geochemistry in tropical and subtropical environments (ed. L. Lacerda). Springer, Berlin.

Machado W., Santelli R., Carvalho M., Molisani M., Barreto R. and Lacerda L. (2008) Relation of Reactive Sulfides with Organic Carbon, Iron, and Manganese in Anaerobic Mangrove Sediments: Implications for Sediment Suitability to Trap Trace Metals. J. Coastal Res. 4, 25-32.

Machado W., Silva-Filho E., Oliveira R. and Lacerda L. (2002) Trace metal retention in mangrove ecosystems in Guanabara Bay, SE Brazil. Mar. Pollut. Bull. 44, 1277-1280.

Maddock J., Carvalho M., Santelli R. and Machado W. (2006) Contaminant Metal Behaviour During Resuspension of Sulphidic Estuarine Sediments. Water Air Soil Pollut. 181, 193-200.

Marchand C., Allenbach M. and Lallier-Vergès E. (2011) Relationships between heavy metals distribution and organic matter cycling in mangrove sediments (Conception Bay, New Caledonia). Geoderma 
160, 444-456.

Marchand C., Lallier-Vergès E., Baltzer F., Albéric P., Cossa D. and Baillif P. (2006) Heavy metals distribution in mangrove sediments along the mobile coastline of French Guiana. Mar. Chem. 98, 117.

Maréchal C., Nicolas E., Douchet C. and Albarède F. (2000) Abundance of zinc isotopes as a marine biogeochemical tracer. Geochem. Geophy. Geosystems 1, (5).

Marèchal C., Télouk P. and Albarède F. (1999) Precise analysis of copper and zinc isotopic compositions by plasma-source mass spectrometry. Chem. Geol. 156, 251-273.

Marques A., Monna F., da Silva Filho E., Fernex F. and Fernando Lamego Simão Filho F. (2006) Apparent discrepancy in contamination history of a sub-tropical estuary evaluated through ${ }^{210} \mathrm{~Pb}$ profile and chronostratigraphical markers. Mar. Pollut. Bull. 52, 532-539.

Martino M., Turner A., Nimmo M. and Millward G. (2002) Resuspension, reactivity and recycling of trace metals in the Mersey Estuary, UK. Mar. Chem. 77, 171-186.

Mason T., Weiss D., Chapman J., Wilkinson J., Tessalina S., Spiro B., Horstwood M., Spratt J. and Coles B. (2005) $\mathrm{Zn}$ and $\mathrm{Cu}$ isotopic variability in the Alexandrinka volcanic-hosted massive sulphide (VHMS) ore deposit, Urals, Russia. Chem. Geol. 221, 170-187.

Mattielli N., Rimetz J., Petit J., Perdrix E., Deboudt K., Flament P. and Weis D. (2006) Zn-Cu isotopic study and speciation of airborne metal particles within a 5-km zone of a lead/zinc smelter. Geochim. Cosmochim. Ac. 70, A401.

Moeller K., Schoenberg R., Pedersen R., Weiss D. and Dong S. (2012) Calibration of the New Certified Reference Materials ERM-AE633 and ERM-AE647 for Copper and IRMM-3702 for Zinc Isotope Amount Ratio Determinations. Geostandards Geoanal.Res. 36, 177-199.

Molisani M.M., Marins R.V., Machado W., Paraquetti H.H.M., Bidone E.D., and Lacerda L.D. (2004) Environmental changes in Sepetiba Bay, SE Brazil. Reg. Environ. Change 4, 17-27.

Montezuma P.N. (2012) Análise de prováveis fatores causadores do processo de assoreamento na Baía de Sepetiba-RJ. In: Bacia hidrográfica dos Rios Guandu, da Guarda e Guandu-Mirim. INEA, Rio de Janeiro.

Morse J. and Luther G. (1999) Chemical influences on trace metal-sulfide interactions in anoxic sediments. Geochim. Cosmochim. Ac. 63, 3373-3378.

Moynier F., Beck P., Yin Q., Ferroir T., Barrat J., Paniello R., Telouk P. and Gillet P. (2010) Volatilization induced by impacts recorded in $\mathrm{Zn}$ isotope composition of ureilites. Chem. Geol. 276, 374-379.

Moynier F., Pichat S., Pons M., Fike D., Balter V. and Albarède F. (2009) Isotopic fractionation and transport mechanisms of $\mathrm{Zn}$ in plants. Chem. Geol. 267, 125-130.

Naidoo G., Hiralal T. and Naidoo Y. (2014) Ecophysiological responses of the mangrove Avicennia marina to trace metal contamination. Flora-Morph., Distr. Funct.. Ecol. Plants 209, 63-72.

Neumann T., Heiser U., Leosson M. and Kersten M. (2002) Early diagenetic processes during Mncarbonate formation: evidence from the isotopic composition of authigenic Ca-rhodochrosites of the Baltic Sea. Geochim. Cosmochim. Ac. 66, 867-879.

Ochoa Gonzalez R. and Weiss D. (2015) Zinc Isotope Variability in Three Coal-Fired Power Plants: A Predictive Model for Determining Isotopic Fractionation during Combustion. Environ. Sci. Technol. 49, 12560-12567.

Otero, X. L., and Macias, F. (2002) Variation with depth and season in metal sulfides in salt marsh soils. Biogeochemistry, 61(3), 247-268.

Otte M., Kearns C. and Doyle M. (1995) Accumulation of arsenic and zinc in the rhizosphere of wetland plants. Bull. Environ. Contam. Toxicol. 55, 154- 161

Patchineelam S., Sanders C., Smoak J., Zem R., Oliveira G. and Patchineelam S. (2011) A historical evaluation of anthropogenic impact in coastal ecosystems by geochemical signatures. J. Braz. Chem. Soc. 22, 120-125.

Pellegatti F., Figueiredo A. and Wasserman J. (2001) Neutron Activation Analysis Applied to the Determination of Heavy Metals and Other Trace Elements in Sediments from Sepetiba Bay (RJ), Brazil. Geostand. Geoanal. Rese. 25, 307-315.

Petit J., Schäfer J., Coynel A., Blanc G., Chiffoleau J., Auger D., Bossy C., Derriennic H., Mikolaczyk M., Dutruch L. and Mattielli N. (2015) The estuarine geochemical reactivity of $\mathrm{Zn}$ isotopes and its 
relevance for the biomonitoring of anthropogenic $\mathrm{Zn}$ and $\mathrm{Cd}$ contaminations from metallurgical activities: Example of the Gironde fluvial-estuarine system, France. Geochim. Cosmochim. Ac. 170, 108-125.

Pichat S., Douchet C. and Albarède F. (2003) Zinc isotope variations in deep-sea carbonates from the eastern equatorial Pacific over the last 175 ka. Earth Planet. Sci.Lett. 210, 167-178.

Pokrovsky O., Viers J. and Freydier R. (2005) Zinc stable isotope fractionation during its adsorption on oxides and hydroxides. J. Colloid Interf. Sc. 291, 192-200.

Purnobasuki H. and Suzuki M. (2005) Functional Anatomy of Air Conducting Network on the Pneumatophores of a Mangrove Plant, Avicennia marina (Forsk.) Vierh. Asian J. Plant Sci. 4, 334347.

Rebelo M., Clara Rebouças do Amaral M. and Chritstian Pfeiffer W. (2003) High Zn and Cd accumulation in the oyster Crassostrea rhizophorae, and its relevance as a sentinel species. Mar. Pollut. Bull. 46, 1354-1358.

Ribeiro A., Figueiredo A., Santos J., Dantas E., Cotrim M., Cesar Lopes Figueira R., V. Silva Filho E. and Cesar Wasserman J. (2013) Combined SEM/AVS and attenuation of concentration models for the assessment of bioavailability and mobility of metals in sediments of Sepetiba Bay (SE Brazil). Mar. Pollut. Bull. 68, 55-63.

Rodrigues M.A.C.; Silvia D.P and Santos S.B. dos.(2012) Baía de Sepetiba: Estado da Arte. Rio de Janeiro. Corbã.

Rodrigues R., Knoppers B., Souza W. and Santos E. (2009) Suspended matter and nutrient gradients of a small-scale river plume in Sepetiba Bay, SE-Brazil. Brazilian Arch. Bio.Tech. 52, 503-512.

Roncarati H., and Carelli S.G. (2012) Consideraçoes sobre estado da arte dos processos geológicos cenozóicos atuantes na baía de Sepeitba. In Baía de Sepetiba: Estado da Arte (ed. M.A.C Rodrigues, S.D Pereira, S.B dos Santos).Corbã, Rio de Janeiro. pp. 12-36.

Sakellari A., Plavšić M., Karavoltsos S., Dassenakis M. and Scoullos M. (2011) Assessment of copper, cadmium and zinc remobilization in Mediterranean marine coastal sediments. Estuar. Coast. Shelf Sci. 91, 1-12.

Shiel A., Weis D. and Orians K. (2010) Evaluation of zinc, cadmium and lead isotope fractionation during smelting and refining. Sci. Total Environ. 408, 2357-2368.

Singh S., Subramanian V. and Gibbs R. (1984) Hydrous Fe and Mn oxides-scavengers of heavy metals in the aquatic environment. Crit. Rev. Environ. Contr. 14, 33-90.

Sivry Y., Riotte J., Sonke J., Audry S., Schafer J., Viers J., Blanc G., Freydier R. and Dupre B. (2008) Zn isotopes as tracers of anthropogenic pollution from Zn-ore smelters The Riou Mort-Lot River system. Chem. Geol. 255, 295-304.

Smoak J.M and Patchineelam S.R (1999) Sediment mixing and accumulation in a mangrove ecosystem evidence from ${ }^{210} \mathrm{~Pb},{ }^{234} \mathrm{Th}$ and ${ }^{7} \mathrm{Be}$. Mang. Salt Marsh. 3:17-27

Sonke J., Sivry Y., Viers J., Freydier R., Dejonghe L., Andre L., Aggarwal J., Fontan F. and Dupre B. (2008) Historical variations in the isotopic composition of atmospheric zinc deposition from a zinc smelter. Chem. Geol. 252, 145-157.

Thapalia A., Borrok D., Van Metre P. and Wilson J. (2015) Zinc Isotopic Signatures in Eight Lake Sediment Cores from Across the United States. Environ. Sci. Technol. 49, 132-140.

Thapalia A., Borrok D., Van Metre P., Musgrove M. and Landa E. (2010) Zn and Cu Isotopes as Tracers of Anthropogenic Contamination in a Sediment Core from an Urban Lake. Environ. Sci Technol. 44, 1544-1550.

Turner A. (1996) Trace-metal partitioning in estuaries: importance of salinity and particle concentration. Mar. Chem. 54, 27-39.

Veeramani H., Eagling J., Jamieson-Hanes J., Kong L., Ptacek C. and Blowes D. (2015) Zinc Isotope Fractionation as an Indicator of Geochemical Attenuation Processes. Environ. Sci. Technol. Lett. 2, 314-319.

Viers J., Oliva P., Nonell A., Gélabert A., Sonke J., Freydier R., Gainville R. and Dupré B. (2007) Evidence of $\mathrm{Zn}$ isotopic fractionation in a soil-plant system of a pristine tropical watershed (Nsimi, Cameroon). Chem. Geol. 239, 124-137. 
Voudouris K., Lambrakis N., Papatheothorou G. and Daskalaki P. (1997) An application of factor analysis for the study of the hydrogeological conditions in Plio-Pleistocene aquifers of NW Achaia (NW peloponnesus, Greece). Mathem. Geol. 29, 43-59.

Weiss D.J., Boye K., Caldelas C. and Fendorf S. (2014). Fractionation of zinc isotopes during early proton and ligand controlled dissolution of biotite granite and implications for plant studies. Soil Sci. Soc. Amer. J., 78, 171-179.

Weiss D., Rausch N., Mason T., Coles B., Wilkinson J., Ukonmaanaho L., Arnold T. and Nieminen T. (2007) Atmospheric deposition and isotope biogeochemistry of zinc in ombrotrophic peat. Geochim. Cosmochim. Ac. 71, 3498-3517.

Yin N., Sivry Y., Benedetti M., Lens P. and van Hullebusch E. (2016) Application of Zn isotopes in environmental impact assessment of $\mathrm{Zn}-\mathrm{Pb}$ metallurgical industries: A mini review. Appl. Geochem. 64, 128-135.

Wasserman J., Figueiredo A., Pellegatti F. and Silva-Filho E. (2001) Elemental composition of sediment cores from a mangrove environment using neutron activation analysis. J. Geochem. Explor. 72, 129146.

Weiss D., Boye K., Caldelas C. and Fendorf S. (2014) Zinc Isotope Fractionation during Early Dissolution of Biotite Granite. Soil Sci. Soc. Am. J. 78, 171.

Weiss D., Mason T., Zhao F., Kirk G., Coles B. and Horstwood M. (2004) Isotopic discrimination of zinc in higher plants. New Phytol.165, 703-710.

Weiss D., Rausch N., Mason T., Coles B., Wilkinson J., Ukonmaanaho L., Arnold T. and Nieminen T. (2007) Atmospheric deposition and isotope biogeochemistry of zinc in ombrotrophic peat. Geochim. Cosmochim. Ac.71, 3498-3517.

Wiederhold J. (2015) Metal Stable Isotope Signatures as Tracers in Environmental Geochemistry. Environ. Sci. Technol. 49, 2606-2624.

Wilkinson J., Weiss D., Mason T. and Coles B. (2005) zinc isotope variation in hydrothermal systems: preliminary evidence from the Irish Midlands ore field. Econ. Geol. 100, 583-590.

Windom H., Niencheski L. and Smith R. (1999) Biogeochemistry of nutrients and trace metals in the estuarine region of the Patos Lagoon (Brazil). Estuar. Coast. Shelf S. 48, 113-123.

Zhao Y., Vance D., Abouchami W. and de Baar H. (2014) Biogeochemical cycling of zinc and its isotopes in the Southern Ocean. Geochim. Cosmochim. Ac. 125, 653-672.

Zhou Y., Peng Y., Li X. and Chen G. (2011) Accumulation and partitioning of heavy metals in mangrove rhizosphere sediments. Environ. Earth Sci. 64, 799-807.

Zwolsman J., Van Eck B. and Van Der Weijden C. (1997) Geochemistry of dissolved trace metals (cadmium, copper, zinc) in the Scheldt estuary, southwestern Netherlands: Impact of seasonal variability. Geochim. Cosmochim. Ac. 61, 1635-1652. 

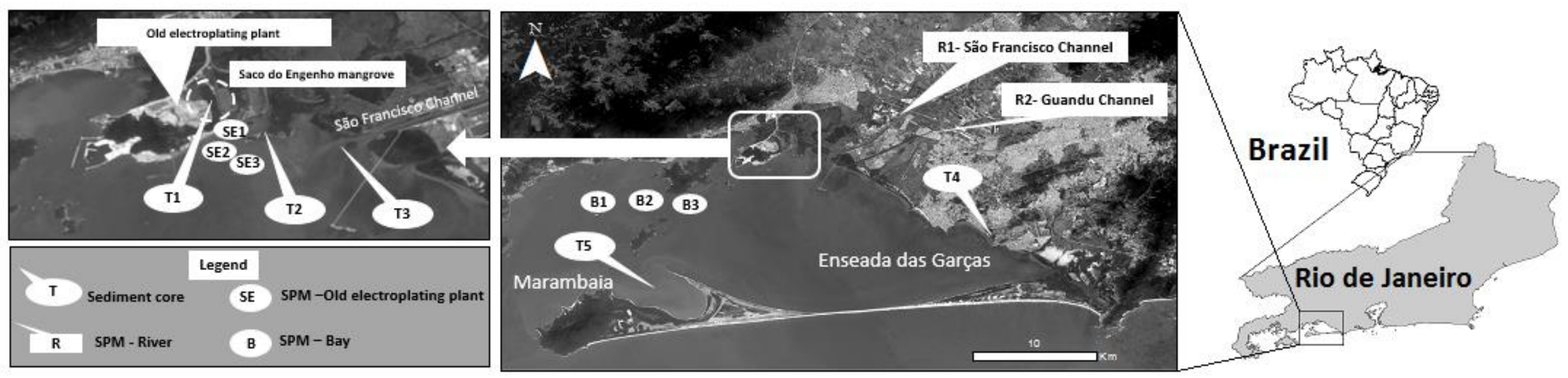

Fig.1. Map of the study area and location of sampling sites. The mangrove surface sediment samples (not shown) were collected in the mangrove of Saco do Engenho, the mangrove region surrounding the São Francisco Channel and the mangrove located in Enseada das Garcas. In the zoom at left is shown the northeastern shore where are located the main river and channels that disembogues in the Sepetiba Bay and the sediments cores collected in the Saco do Engenhos'mangrove (T1), in the inner bay close the mouth of Saco do Engenho (T2) and in the estuary mouth of São Francisco Channel (T3). 
T1- SACO DO ENGENHO
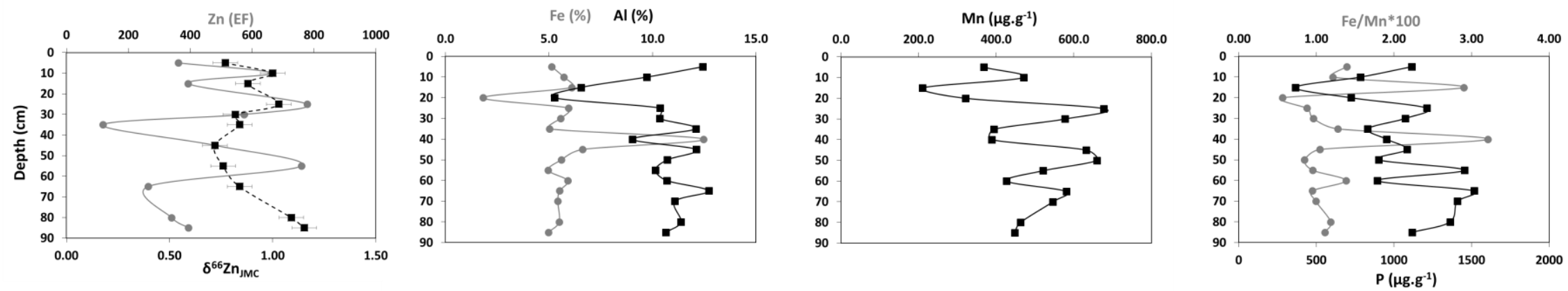

T2- SACO DO ENGENHO MOUTH
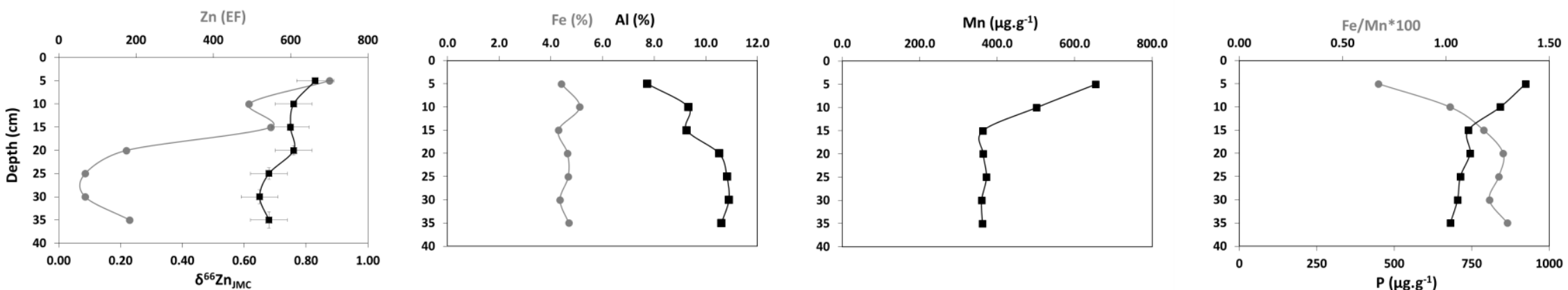

\section{T3- SÃO FRANCISCO}
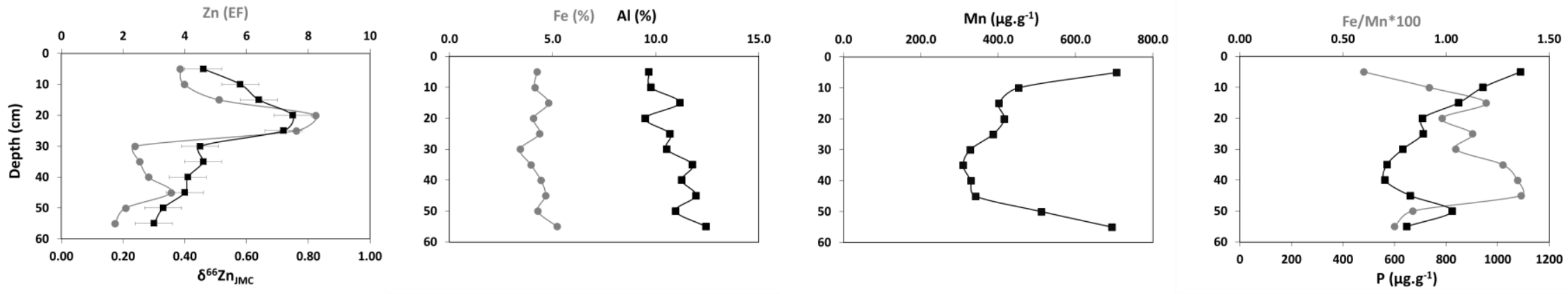

Fig.2. Sediment core profiles of the $\delta^{66} \mathrm{Zn}_{\mathrm{JMC}}$ values, $\mathrm{Zn}$ enrichment factor (EF) and major elements. 


\section{T4- ENSEADA DAS GARÇAS}
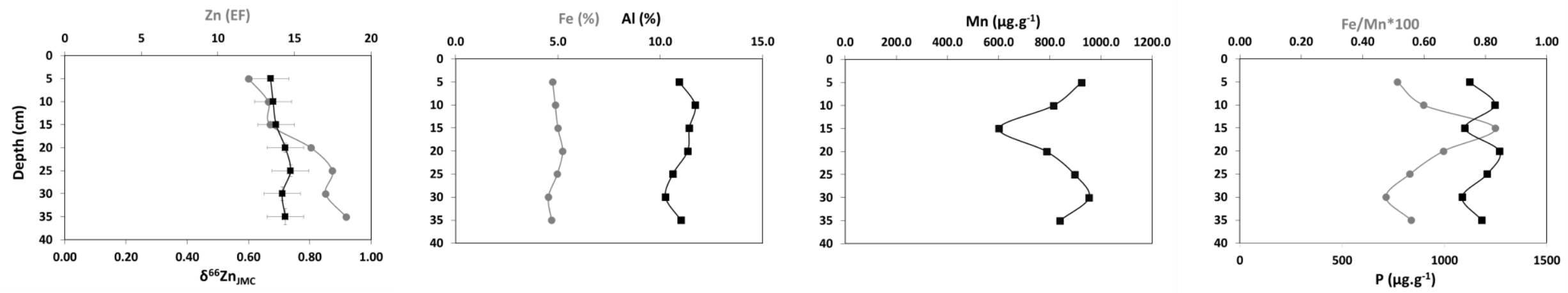

\section{T5- MARAMBAIA}
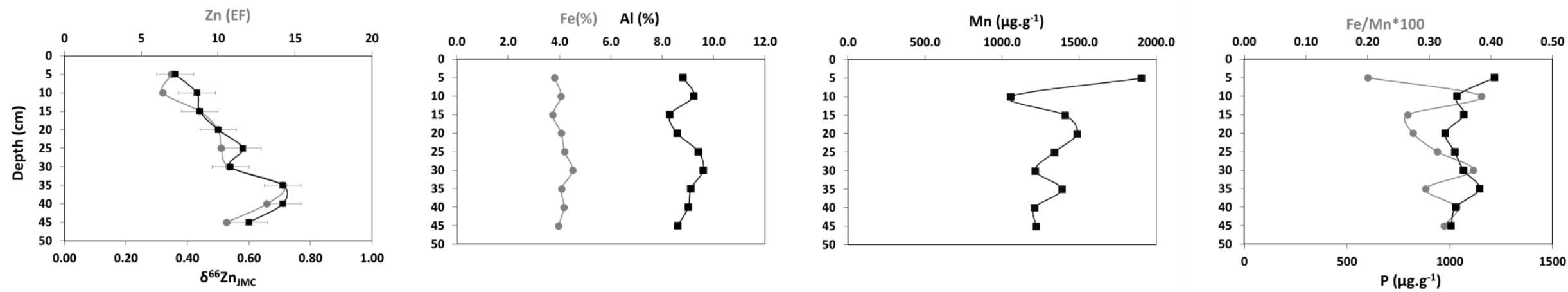

Fig.2. Continuation: Sediment core profiles of the $\delta^{66} \mathrm{Zn}_{\mathrm{JMC}}$ values, $\mathrm{Zn}$ enrichment factor (EF) and major elements. 

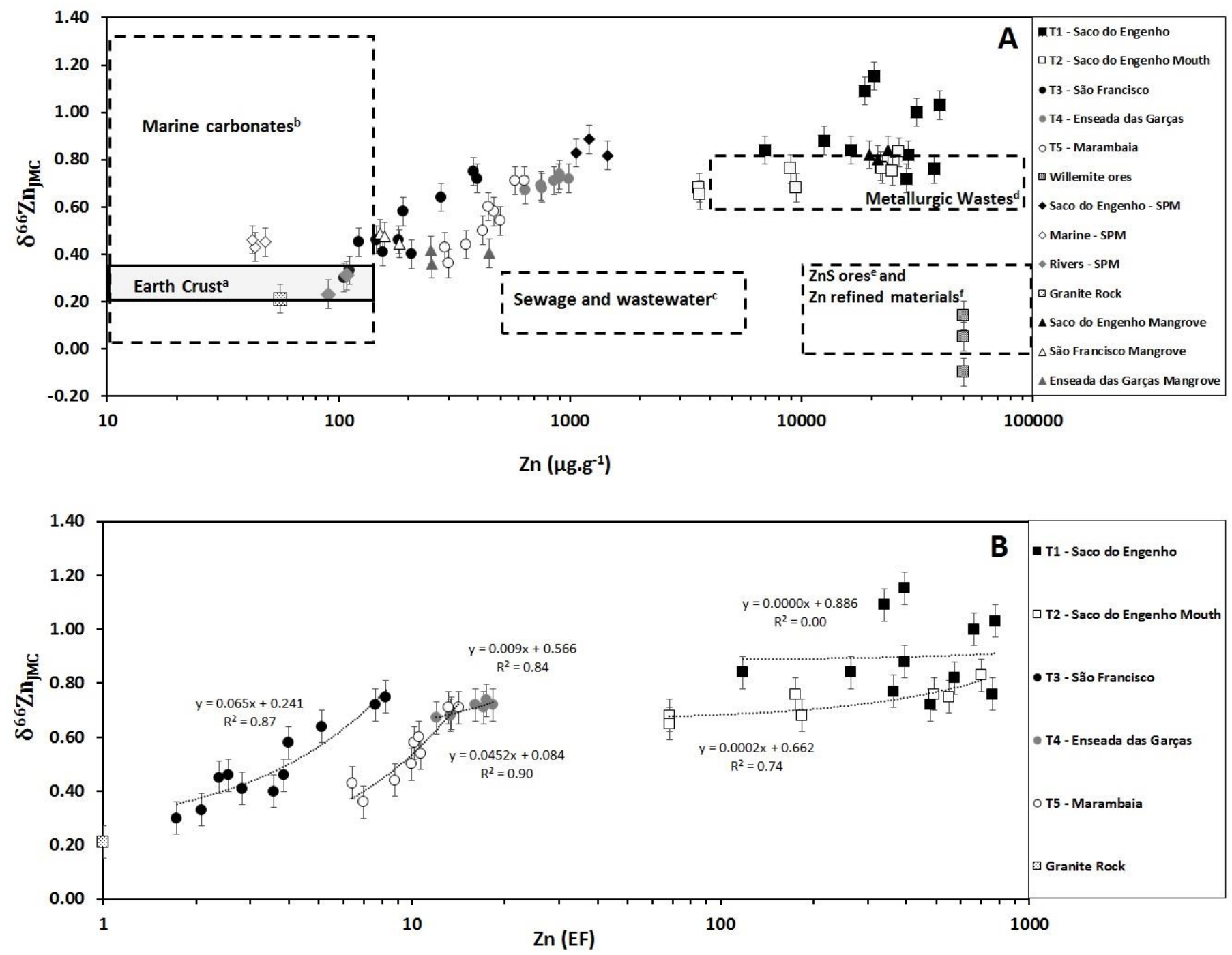

Fig.3. (A) The plot between $\delta^{66} \mathrm{Zn}_{\mathrm{JMC}}$ values against $\mathrm{Zn}$ concentrations of granite rocks, sediment samples (SPM, cores and from surface of mangroves) and willemite ores. The dashed squares and the grey rectangle (highlighting the Earth crust) indicate $\delta^{66} \mathrm{Zn}_{\mathrm{JMC}}$ values of naturals and anthropogenic materials reported in the literature for: a- the Earth Crust $(+0.28$ $\pm 0.05 \%$, $2 \sigma$, Chen et al., 2013); b- Marine carbonates (from +0.04 to $+1.34 \%$, Kunzmann et al.2013; Pichat et al., 2003); cSewage and wastewater (from +0.08 to $+0.31 \%$; Chen et al., 2009); d- Metallurgic wastes (from +0.59 to +0.81 , excluding outliers, Jullliot et al., 2011; Sivry et al., 2008); e- ZnS ores (+0.16 $\pm 0.20 \%$, $2 \sigma$, Sonke et al., 2008); f- Zn refined materials (from +0.1 to +0.3 , John et al., 2007). (B) The plots between $\delta^{66} \mathrm{Zn}_{\text {JMC }}$ against concentration and enrichment factor (EF) of the core samples and the respective correlations $\left(\mathrm{R}^{2}\right)$. T1 core did not present a clear relation between $\delta^{66} \mathrm{Zn}$ values and EF, but at the first $35 \mathrm{~cm}$ a moderate correlation of $\mathrm{R}^{2}=0.51$ was obtained (not shown). 


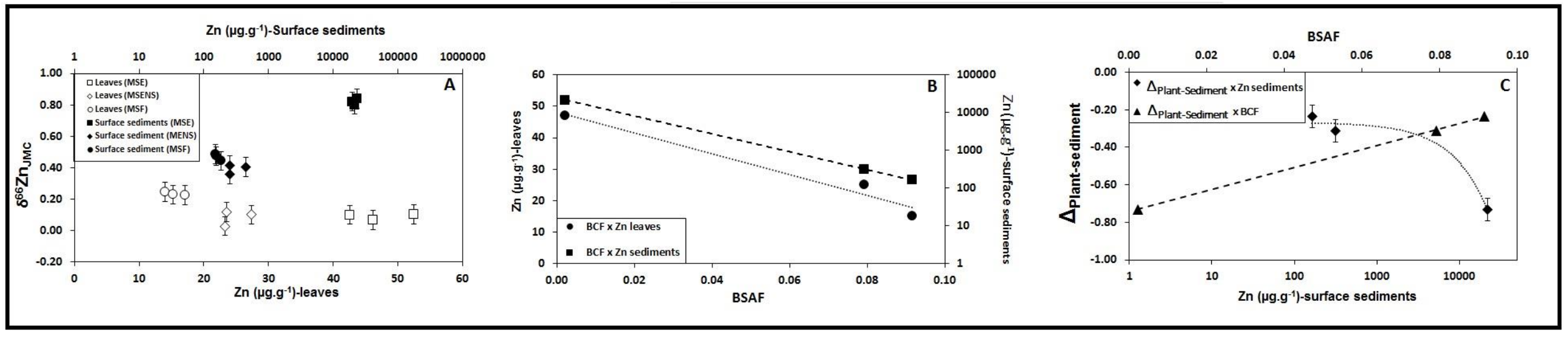

Fig.4. (A) The plots of $\delta^{66} \mathrm{Zn}_{\mathrm{JMC}}$ values against $\mathrm{Zn}$ concentrations of leaves (L.racemosa) and surface sediment samples; (B) BSAF against $\mathrm{Zn}$ concentrations of leaves and

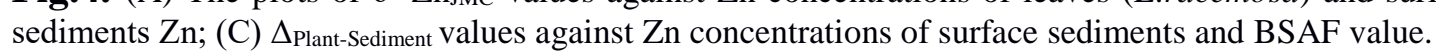



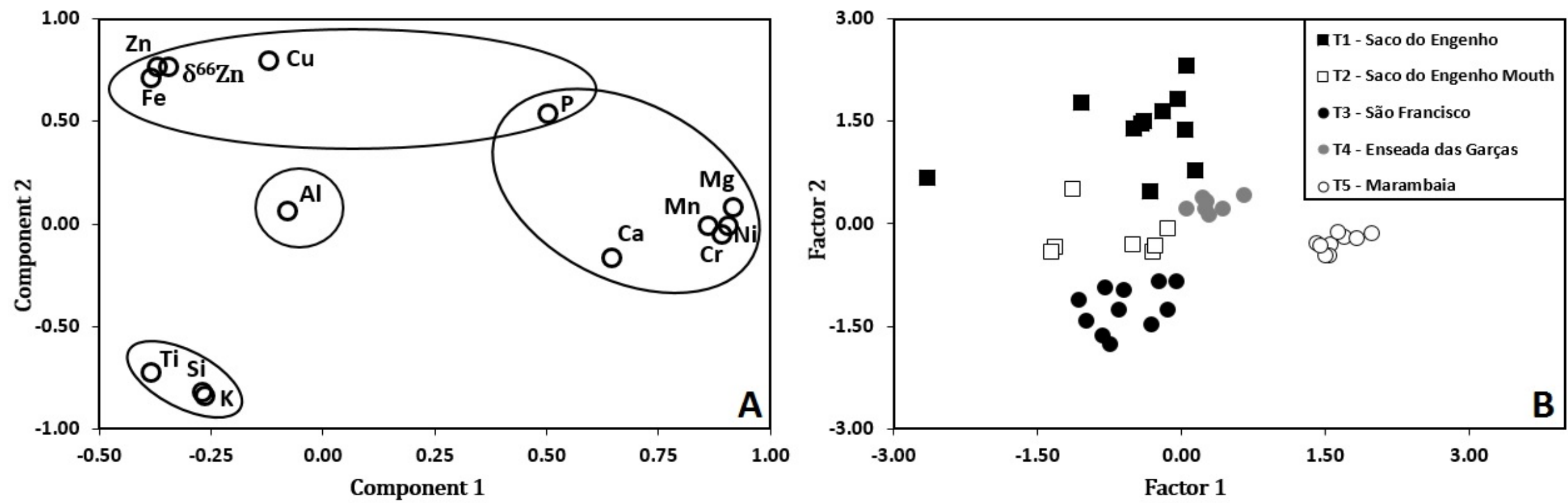

Fig.5. The plots of the variables factor loads (A) and sample factor scores (B) obtained in PCA analysis. 

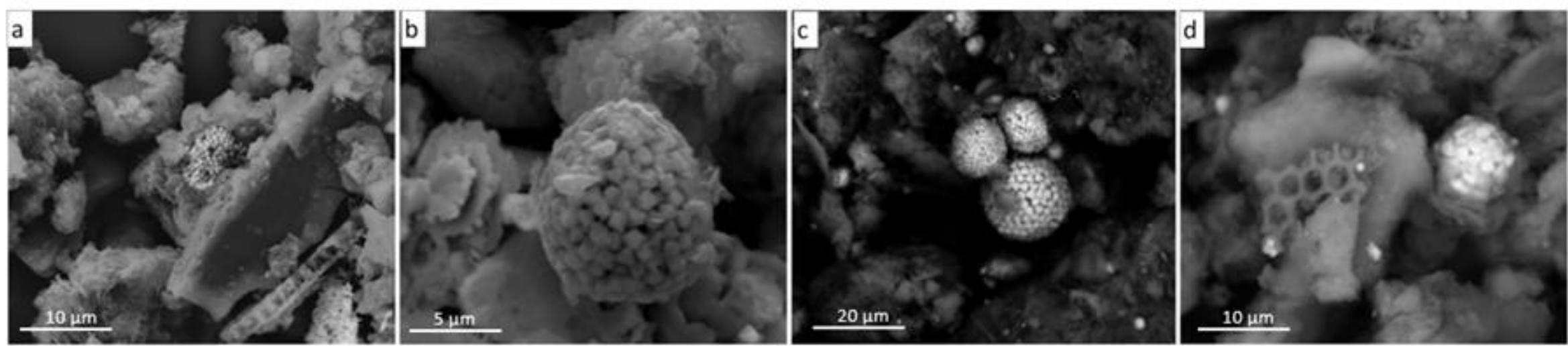

Fig.6. Scanning electron microscope (SEM): (a) framboids and diatoms; (b) framboids in details; (c) association of many framboids; (d) framboids coated by clayminerals. 


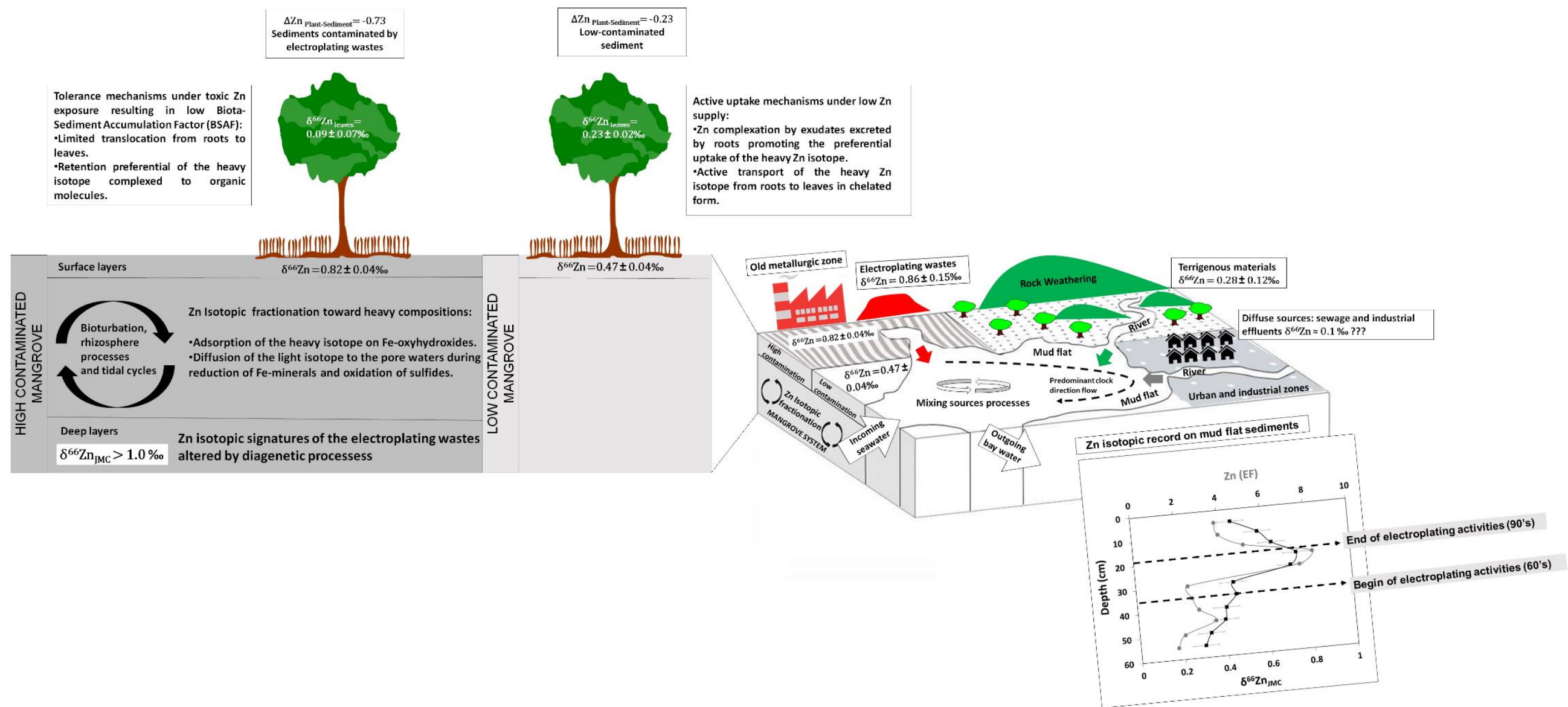

Fig.7. Summary of the main findings obtained in this study on Sepetiba bay: the main sources identified with Zn isotopes: electroplating wastes as the major anthropogenic source, terrigenous and marine materials. Diffuse sources with a hypothetic $\delta^{66} \mathrm{Zn}_{\mathrm{JMC}}$ values $\approx 0.1 \%$ are suspected of influencing of the isotopic record of cores at southern region of the bay. In the mangrove profile collected in the old metallurgic zone, superficial layers are similar to SPM exported to the bay and the mud flat isotopic signatures. The deepest layers tends to heavier isotopic compositions possibly due the $\mathrm{Zn}$ isotopic fractionation related to combination of diagenetic processes, bioturbation, rhizosphere processes that taking place within sediments. Leaves isotopic signatures change from mangrove trees under high toxicity levels of $\mathrm{Zn}$ contamination to that under low contamination. 


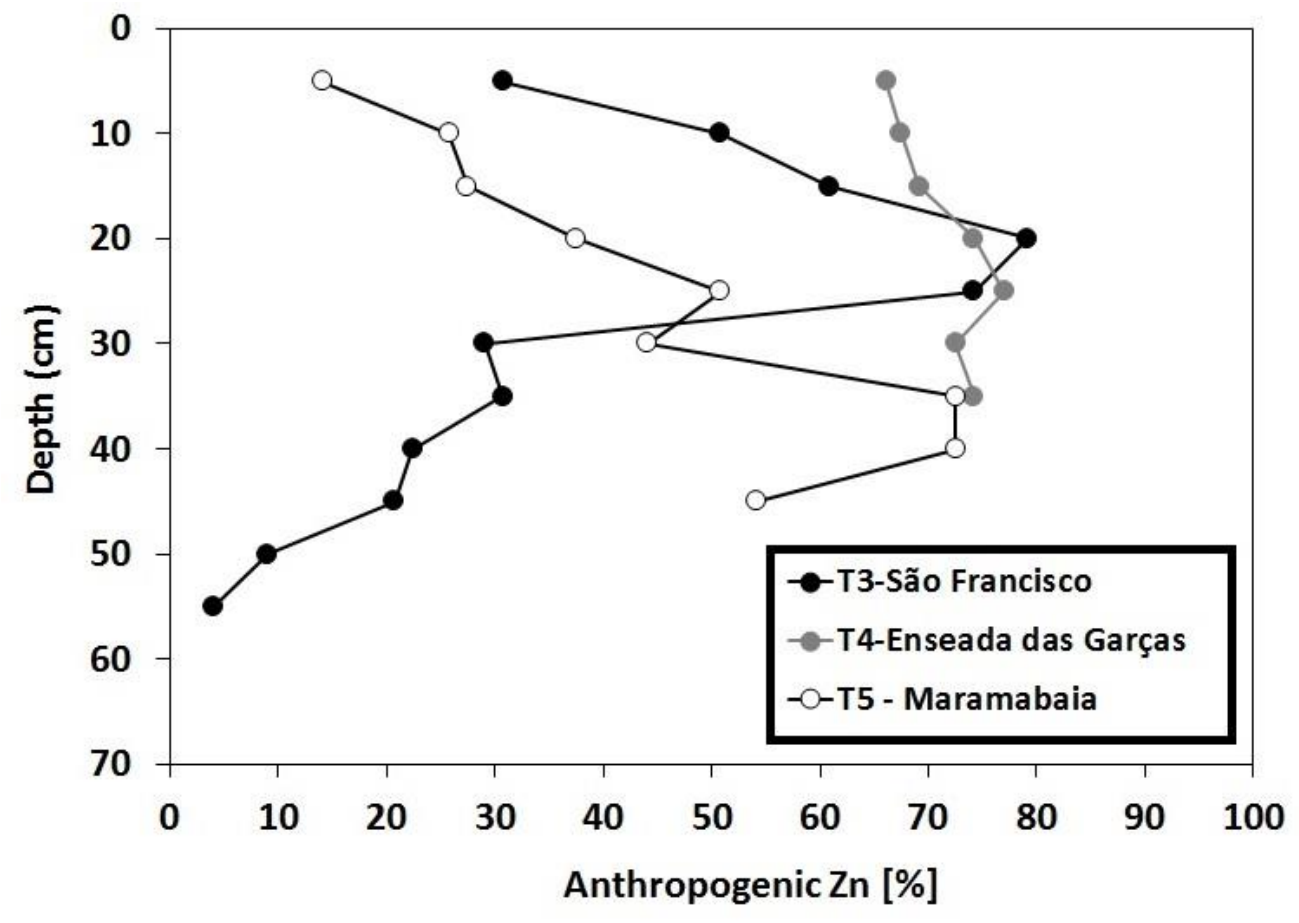

Fig.8. Quantification of anthropogenic $\mathrm{Zn}$ in the cores of inner bay. A mixing model was used to quantify the influence of electroplating wastes along the time. The representative $\delta^{66} \mathrm{Zn}$ values of end members were $+0.86 \pm 0.15 \%$ o $(2 \sigma)$ and $+0.28 \pm 0.12 \%$ o $(2 \sigma)$ to electroplating wastes and continental source (terrigenous materials brought by the rivers) respectively. 
Table 1. Data set of sediment cores, granite rocks and willemite ores samples.

\begin{tabular}{|c|c|c|c|c|c|c|c|c|c|c|c|c|c|c|c|}
\hline Samples & $\delta^{66} \mathrm{Zn}$ & $\begin{array}{c}\mathbf{Z n} \\
(\mathbf{E F})\end{array}$ & $\begin{array}{c}\mathrm{Zn} \\
\left(\mu \mathrm{g} \cdot \mathrm{g}^{-1}\right)\end{array}$ & $\begin{array}{c}\mathrm{Ca} \\
(\%) \\
\end{array}$ & $\begin{array}{l}\mathrm{Mg} \\
(\%) \\
\end{array}$ & $\begin{array}{c}\mathbf{T i} \\
(\%) \\
\end{array}$ & $\begin{array}{c}\mathrm{Fe} \\
(\%)\end{array}$ & $\begin{array}{c}\mathbf{S i} \\
(\%) \\
\end{array}$ & $\begin{array}{c}\text { Al } \\
(\%)\end{array}$ & $\begin{array}{c}K \\
(\%) \\
\end{array}$ & $\begin{array}{c}\text { Mn } \\
\left(\mu \mathrm{g} \cdot \mathrm{g}^{-1}\right)\end{array}$ & $\begin{array}{c}P \\
\left(\mu g . g^{-1}\right)\end{array}$ & $\begin{array}{c}\mathrm{Ni} \\
\left(\mu \mathrm{g} \cdot \mathrm{g}^{-1}\right)\end{array}$ & $\begin{array}{c}\mathrm{Cr} \\
\left(\mu \mathrm{g} . \mathrm{g}^{-1}\right)\end{array}$ & $\begin{array}{c}\mathrm{Cu} \\
\left(\mu \mathrm{g} . \mathrm{g}^{-1}\right)\end{array}$ \\
\hline \multicolumn{16}{|c|}{ T1 Core-Saco do Engenho } \\
\hline T1 0-5 & 0.77 & 362 & 21,960 & 3.9 & 0.9 & 0.5 & 5.1 & 19.6 & 12.4 & 0.8 & 368.5 & 1115 & 20.9 & 57.9 & 75.6 \\
\hline T1 5-10 & 1.00 & 663 & 31,410 & 1.0 & 0.8 & 0.5 & 5.7 & 17.1 & 9.7 & 0.4 & 470.6 & 783 & 16.3 & 54.2 & 175.4 \\
\hline $\mathrm{T} 1 \mathrm{10}-15$ & 0.88 & 394 & 12,560 & 1.3 & 0.6 & 0.5 & 6.1 & 28.9 & 6.5 & 0.6 & 210.4 & 366 & 5.4 & 22.9 & 67.5 \\
\hline T1 $15-20$ & & 208 & 5,330 & 1.4 & 0.4 & 0.2 & 1.8 & 33.7 & 5.3 & 0.6 & 321.3 & 725 & 13.5 & 43.5 & 175.6 \\
\hline T1 20-25 & 1.03 & 778 & 39,330 & 1.1 & 1.0 & 0.5 & 5.9 & 17.0 & 10.4 & 0.6 & 677.4 & 1213 & 24.1 & 74.6 & 329.3 \\
\hline $\mathrm{T} 125-30$ & 0.82 & 574 & 28,980 & 0.8 & 0.9 & 0.5 & 5.6 & 16.7 & 10.3 & 0.6 & 577.5 & 1072 & 22.4 & 64.7 & 223.6 \\
\hline T1 30-35 & 0.84 & 118 & 6,970 & 0.8 & 0.8 & 0.5 & 5.0 & 20.2 & 12.1 & 0.8 & 393.9 & 832 & 21.6 & 59.9 & 56.5 \\
\hline T1 35-40 & & 204 & 9,000 & 1.1 & 0.8 & 0.5 & 12.5 & 17.2 & 9.0 & 0.7 & 388.3 & 953 & 18.8 & 64.9 & 133.4 \\
\hline T1 40-45 & 0.72 & 480 & 28,370 & 0.6 & 1.0 & 0.6 & 6.6 & 17.7 & 12.1 & 1.2 & 631.7 & 1084 & 17.3 & 63.5 & 206.5 \\
\hline $\mathrm{T} 145-50$ & & 434 & 22,640 & 0.6 & 0.9 & 0.6 & 5.6 & 18.1 & 10.7 & 1.2 & 659.3 & 903 & 21.4 & 65 & 238.1 \\
\hline T1 50-55 & 0.76 & 759 & 37,540 & 0.5 & 1.0 & 0.5 & 5.0 & 16.6 & 10.1 & 0.9 & 520.6 & 1455 & 22.9 & 61.9 & 324 \\
\hline T1 55-60 & & 775 & 40,400 & 1.0 & 1.0 & 0.6 & 5.9 & 19.3 & 10.7 & 1.1 & 426.8 & 894 & 19.6 & 61.8 & 105 \\
\hline T1 60-65 & 0.84 & 264 & 16,350 & 0.7 & 1.0 & 0.5 & 5.5 & 20.4 & 12.7 & 1.2 & 580.5 & 1518 & 22.7 & 58.3 & 342.7 \\
\hline $\mathrm{T} 165-70$ & & 789 & 42,620 & 0.6 & 1.1 & 0.5 & 5.4 & 16.5 & 11.1 & 0.9 & 546.0 & 1408 & 18.8 & 51 & 178.1 \\
\hline $\mathrm{T} 175-80$ & 1.09 & 340 & 18,830 & 0.6 & 1.0 & 0.6 & 5.5 & 17.9 & 11.4 & 1.0 & 462.6 & 1361 & 19.4 & 56 & 168 \\
\hline T1 80-85 & 1.15 & 394 & 20,470 & 0.5 & 1.0 & 0.5 & 5.0 & 17.6 & 10.6 & 0.9 & 447.4 & 1118 & 20.7 & 58.2 & 183.5 \\
\hline \multicolumn{16}{|c|}{ T2 Core-Saco do Engenho Mouth } \\
\hline T2 0-5 & 0.83 & 700 & 26,410 & 0.5 & 0.5 & 0.6 & 4.4 & 19.0 & 7.7 & 1.8 & 654.4 & 924 & 14.4 & 56.5 & 29.6 \\
\hline T2 5-10 & 0.76 & 492 & 22,360 & 0.6 & 0.7 & 0.9 & 5.1 & 25.1 & 9.3 & 2.8 & 501.8 & 843 & 13.9 & 57.4 & 24.3 \\
\hline $\mathrm{T} 2$ 10-15 & 0.75 & 549 & 24,790 & 0.6 & 0.7 & 0.9 & 4.3 & 25.3 & 9.3 & 2.2 & 362.8 & 739 & 13.8 & 58.3 & 21.7 \\
\hline $\mathrm{T} 2$ 15-20 & 0.76 & 175 & 8,990 & 0.7 & 1.0 & 0.7 & 4.6 & 22.9 & 10.5 & 1.9 & 363.8 & 745 & 18.8 & 65.8 & 18 \\
\hline T2 20-25 & 0.68 & 68 & 3,610 & 0.8 & 1.1 & 0.7 & 4.7 & 23.3 & 10.8 & 1.7 & 372.2 & 713 & 19.5 & 64.7 & 17.1 \\
\hline T2 25-30 & 0.65 & 68 & 3,630 & 0.6 & 1.1 & 0.6 & 4.4 & 21.6 & 10.9 & 1.5 & 359.7 & 704 & 19.4 & 62.5 & 16.2 \\
\hline T2 30-35 & 0.68 & 184 & 9,500 & 0.5 & 1.3 & 0.6 & 4.7 & 21.0 & 10.6 & 1.5 & 361.6 & 681 & 20.8 & 68.0 & 23.5 \\
\hline
\end{tabular}


Table 1. Continuation

\begin{tabular}{|c|c|c|c|c|c|c|c|c|c|c|c|c|c|c|c|}
\hline Samples & $\delta^{66} \mathrm{Zn}$ & Zn EF & $\begin{array}{c}\mathrm{Zn} \\
\left(\mu \mathrm{g}^{-g^{-1}}\right)\end{array}$ & $\begin{array}{l}\mathrm{Ca} \\
(\%)\end{array}$ & $\begin{array}{l}\mathrm{Mg} \\
(\%)\end{array}$ & $\begin{array}{c}\mathbf{T i} \\
(\%)\end{array}$ & $\begin{array}{c}\mathrm{Fe} \\
(\%)\end{array}$ & $\begin{array}{c}\mathbf{S i} \\
(\%)\end{array}$ & $\begin{array}{c}\text { Al } \\
(\%)\end{array}$ & $\begin{array}{c}K \\
(\%)\end{array}$ & $\begin{array}{c}\text { Mn } \\
\left(\mu g^{\prime} g^{-1}\right)\end{array}$ & $\begin{array}{c}P \\
\left(\mu g^{\prime} g^{-1}\right)\end{array}$ & $\begin{array}{c}\mathrm{Ni} \\
\left(\mu \mathrm{g} . \mathrm{g}^{-1}\right)\end{array}$ & $\begin{array}{c}\mathrm{Cr} \\
\left(\mu \mathrm{g} \cdot \mathrm{g}^{-1}\right)\end{array}$ & $\begin{array}{c}\mathrm{Cu} \\
\left(\mu \mathrm{g} . \mathrm{g}^{-1}\right)\end{array}$ \\
\hline \multicolumn{16}{|c|}{ T3 Core-São Francisco } \\
\hline T3 0-5 & 0.46 & 3.8 & 181 & 1.4 & 0.7 & 1.5 & 4.2 & 30.1 & 9.7 & 2.6 & 706.0 & 1088 & 17.5 & 55.4 & 20.1 \\
\hline T3 5-10 & 0.58 & 4.0 & 189 & 1.2 & 0.7 & 1.3 & 4.1 & 27.8 & 9.8 & 2.5 & 452.0 & 943 & 14.8 & 57 & 17.9 \\
\hline T3 $10-15$ & 0.64 & 5.1 & 278 & 1.3 & 0.8 & 1.0 & 4.8 & 26.0 & 11.2 & 2.1 & 401.9 & 848 & 19 & 61.3 & 23.8 \\
\hline T3 $15-20$ & 0.75 & 8.2 & 381 & 1.2 & 0.7 & 1.1 & 4.1 & 27.6 & 9.5 & 2.2 & 415.8 & 708 & 16.1 & 55 & 19.4 \\
\hline T3 20-25 & 0.72 & 7.6 & 397 & 1.0 & 0.7 & 0.9 & 4.4 & 26.3 & 10.7 & 2.0 & 386.5 & 711 & 18.5 & 59.6 & 23.9 \\
\hline T3 $25-30$ & 0.45 & 2.4 & 122 & 1.1 & 0.7 & 0.9 & 3.4 & 28.3 & 10.5 & 2.5 & 327.6 & 632 & 17 & 56.9 & 19.7 \\
\hline T3 30-35 & 0.46 & 2.5 & 146 & 1.1 & 0.8 & 0.7 & 3.9 & 26.6 & 11.8 & 2.2 & 309.4 & 571 & 20.1 & 51.2 & 22.6 \\
\hline T3 $35-40$ & 0.41 & 2.8 & 155 & 0.9 & 0.9 & 0.7 & 4.4 & 22.7 & 11.3 & 1.7 & 328.9 & 563 & 23.4 & 59.8 & 29.6 \\
\hline T3 $40-45$ & 0.40 & 3.6 & 207 & 0.8 & 0.8 & 0.7 & 4.7 & 22.9 & 12.0 & 1.6 & 341.4 & 661 & 26.1 & 63.4 & 30.6 \\
\hline T3 45-50 & 0.33 & 2.1 & 111 & 1.1 & 0.8 & 1.2 & 4.3 & 24.8 & 11.0 & 2.3 & 511.5 & 823 & 22.2 & 58.8 & 27.4 \\
\hline T3 50-55 & 0.30 & 1.7 & 105 & 0.8 & 0.8 & 0.8 & 5.2 & 25.7 & 12.4 & 2.5 & 693.9 & 647 & 24 & 62.4 & 27.2 \\
\hline \multicolumn{16}{|c|}{ T4 Core-Enseada das Garças } \\
\hline T4 0-5 & 0.67 & 12.0 & 639 & 1.1 & 1.1 & 0.5 & 4.7 & 19.3 & 10.9 & 0.8 & 923.8 & 1123 & 18.6 & 55.5 & 23.5 \\
\hline $\mathrm{T} 45-10$ & 0.68 & 13.3 & 758 & 1.1 & 1.1 & 0.6 & 4.9 & 20.5 & 11.7 & 1.0 & 813.9 & 1246 & 21.2 & 63.7 & 29.3 \\
\hline T4 10-15 & 0.69 & 13.4 & 747 & 0.9 & 1.1 & 0.6 & 5.0 & 22.3 & 11.4 & 1.0 & 600.7 & 1100 & 23.6 & 63 & 32.8 \\
\hline $\mathrm{T} 415-20$ & 0.72 & 16.1 & 888 & 0.8 & 1.2 & 0.6 & 5.2 & 20.1 & 11.3 & 1.0 & 787.9 & 1269 & 24.4 & 72.2 & 36.3 \\
\hline $\mathrm{T} 420-25$ & 0.74 & 17.5 & 904 & 0.8 & 1.0 & 0.7 & 5.0 & 20.0 & 10.6 & 1.0 & 897.4 & 1209 & 20.9 & 65.5 & 35.4 \\
\hline $\mathrm{T} 425-30$ & 0.71 & 17.0 & 852 & 0.8 & 1.0 & 0.6 & 4.5 & 21.0 & 10.3 & 1.0 & 953.3 & 1086 & 18.7 & 59.2 & 31.7 \\
\hline T4 30-35 & 0.72 & 18.4 & 986 & 0.8 & 1.0 & 0.6 & 4.7 & 21.2 & 11.0 & 1.0 & 838.8 & 1182 & 20.7 & 63.1 & 36.7 \\
\hline \multicolumn{16}{|c|}{ T5 Core-Marambaia } \\
\hline T5 0-5 & 0.36 & 6.9 & 298 & 3.1 & 1.5 & 0.5 & 3.8 & 20.1 & 8.8 & 1.1 & 1903.7 & 1218 & 25.8 & 76 & 27 \\
\hline T5 5-10 & 0.43 & 6.4 & 288 & 3.0 & 1.6 & 0.5 & 4.1 & 22.0 & 9.2 & 1.2 & 1055.5 & 1036 & 24.8 & 73.5 & 19.7 \\
\hline T5 10-15 & 0.44 & 8.8 & 356 & 2.6 & 1.5 & 0.5 & 3.7 & 20.8 & 8.3 & 1.1 & 1408.8 & 1069 & 27.3 & 79.6 & 23.6 \\
\hline T5 $15-20$ & 0.50 & 10.0 & 418 & 2.9 & 1.5 & 0.6 & 4.1 & 22.5 & 8.6 & 1.3 & 1486.2 & 979 & 25.8 & 79.5 & 23.1 \\
\hline T5 $20-25$ & 0.58 & 10.2 & 467 & 1.8 & 1.6 & 0.6 & 4.2 & 26.4 & 9.4 & 1.5 & 1338.8 & 1024 & 27.4 & 88.7 & 23.2 \\
\hline
\end{tabular}


Table 1. Continuation

\begin{tabular}{|c|c|c|c|c|c|c|c|c|c|c|c|c|c|c|c|}
\hline Samples & $\delta^{66} \mathrm{Zn}$ & $\begin{array}{c}\mathbf{Z n} \\
(\mathrm{EF})\end{array}$ & $\begin{array}{c}\mathrm{Zn} \\
\left(\mu \mathrm{g}^{\left.-g^{-1}\right)}\right.\end{array}$ & $\begin{array}{c}\mathrm{Ca} \\
(\%) \\
\end{array}$ & $\begin{array}{l}\text { Mg } \\
(\%) \\
\end{array}$ & $\begin{array}{c}\mathbf{T i} \\
(\%) \\
\end{array}$ & $\begin{array}{c}\mathrm{Fe} \\
(\%) \\
\end{array}$ & $\begin{array}{c}\mathbf{S i} \\
(\%) \\
\end{array}$ & $\begin{array}{c}\text { Al } \\
(\%)\end{array}$ & $\begin{array}{c}K \\
(\%) \\
\end{array}$ & $\begin{array}{c}\text { Mn } \\
\left(\mu \mathrm{g} \cdot \mathrm{g}^{-1}\right)\end{array}$ & $\begin{array}{c}\mathbf{P} \\
\left(\mu \mathrm{g} \cdot \mathrm{g}^{-1}\right)\end{array}$ & $\begin{array}{c}\mathrm{Ni} \\
\left(\mu \mathrm{g} \cdot \mathrm{g}^{-1}\right)\end{array}$ & $\begin{array}{c}\mathrm{Cr} \\
\left(\mu \mathrm{g} \cdot \mathrm{g}^{-1}\right)\end{array}$ & $\begin{array}{c}\mathrm{Cu} \\
\left(\mu \mathrm{g} \cdot \mathrm{g}^{-1}\right)\end{array}$ \\
\hline \multicolumn{16}{|c|}{ T5-Core-Marambaia } \\
\hline T5 25-30 & 0.54 & 10.7 & 501 & 2.3 & 1.6 & 0.7 & 4.5 & 24.8 & 9.6 & 1.5 & 1214.8 & 1067 & 26.3 & 88.7 & 24.4 \\
\hline T5 30-35 & 0.71 & 14.2 & 632 & 1.8 & 1.5 & 0.6 & 4.1 & 23.5 & 9.1 & 1.5 & 1387.0 & 1144 & 30.8 & 94.2 & 28.5 \\
\hline T5 $35-40$ & 0.71 & 13.2 & 578 & 2.5 & 1.5 & 0.7 & 4.2 & 23.8 & 9.0 & 1.6 & 1209.7 & 1030 & 28.2 & 84.6 & 22.3 \\
\hline T5 $40-45$ & 0.60 & 10.5 & 442 & 2.8 & 1.4 & 0.6 & 4.0 & 19.3 & 8.6 & 1.3 & 1220.9 & 1006 & 27.8 & 86.5 & 22.2 \\
\hline Granite & 0.21 & 1 & 56 & 3.0 & 0.3 & 0.5 & 4.3 & 28.9 & 11.5 & 6.7 & 1071.4 & 1430 & 6.9 & 10 & 7.3 \\
\hline \multicolumn{16}{|c|}{ Willemite ores } \\
\hline Willemite 1 & -0.10 & & & & & & & & & & & & & & \\
\hline willemite 2 & 0.05 & & & & & & & & & & & & & & \\
\hline willemite 3 & 0.14 & & & & & & & & & & & & & & \\
\hline
\end{tabular}


Table 2. Data set of mangrove superficial sediments and Laguncularia Racemosa leaf samples.

\begin{tabular}{|c|c|c|c|c|c|c|c|c|c|c|c|c|c|c|}
\hline & $\delta$ & $\begin{array}{c}\mathrm{Zn} \\
\text { (EF) }\end{array}$ & $\begin{array}{c}\mathrm{Zn} \\
\left(\mu \mathrm{gg} \cdot \mathrm{g}^{-1}\right)\end{array}$ & $\begin{array}{c}\text { Ca } \\
(\%)\end{array}$ & $\begin{array}{c}\text { Mg } \\
(\%)\end{array}$ & $\begin{array}{r}\mathbf{T i} \\
(\%\end{array}$ & $\begin{array}{c}\mathbf{F e} \\
(\%)\end{array}$ & $\begin{array}{c}\mathbf{S i} \\
(\%)\end{array}$ & $\begin{array}{c}\text { Al } \\
(\%)\end{array}$ & $\begin{array}{c}K \\
(\%)\end{array}$ & $\begin{array}{c}\text { Mn } \\
\left(\mu g^{-1} g^{-1}\right)\end{array}$ & $\begin{array}{c}P \\
\left(\mu \mathrm{g} \cdot \mathrm{g}^{-1}\right)\end{array}$ & $\begin{array}{c}\mathrm{Ni} \\
\left(\mu \mathrm{g} . \mathrm{g}^{-1}\right)\end{array}$ & $\begin{array}{c}\mathrm{Cr} \\
\left(\mu \mathrm{g} \cdot \mathrm{g}^{-1}\right)\end{array}$ \\
\hline
\end{tabular}

Saco do Engenho Mangrove (MSE station)

\begin{tabular}{|c|c|c|c|c|c|c|c|c|c|c|c|c|c|c|c|}
\hline Sediment MSE 1 & 0.80 & 364 & 21,387 & 0.5 & 1.0 & 0.6 & 10.3 & 20.2 & 12.1 & 1.1 & 255.1 & 877 & 21.4 & 57 & 41.9 \\
\hline Sedimet MSE 2 & 0.82 & 362 & 19,566 & 0.4 & 0.9 & 0.6 & 10.2 & 18.7 & 11.1 & 1.1 & 308.0 & 887 & 21.3 & 57.3 & 44.3 \\
\hline Sediment MSE 3 & 0.84 & 395 & 23,700 & 0.5 & 0.9 & 0.6 & 10.6 & 20.3 & 12.3 & 1.2 & 543.8 & 1111 & 21 & 59 & 38 \\
\hline Leaves MSE $^{\mathrm{a}}$ & $0.09 \pm 0.04$ & & $47 \pm 5$ & & & & & & & & & & & & \\
\hline
\end{tabular}

São Francisco Mangrove (MSF station)

\begin{tabular}{|c|c|c|c|c|c|c|c|c|c|c|c|c|c|c|c|}
\hline Sediment MSF 1 & 0.49 & 3.0 & 151 & 1.0 & 0.5 & 1.1 & 3.8 & 32.1 & 10.5 & 3.2 & 364.3 & 759 & 12.9 & 48.1 & 14.9 \\
\hline Sediment MSF 2 & 0.44 & 3.5 & 183 & 1.1 & 0.6 & 1.5 & 4.7 & 29.2 & 10.7 & 2.9 & 440.5 & 350 & 15.4 & 62.7 & 19 \\
\hline Sediment MSF 3 & 0.47 & 3.3 & 158 & 1.3 & 0.5 & 1.1 & 3.7 & 30.2 & 9.7 & 2.9 & 359.5 & 789 & 12 & 55.1 & 15.6 \\
\hline Leafs MSF ${ }^{a}$ & $0.08 \pm 0.10$ & & $15 \pm 2$ & & & & & & & & & & & & \\
\hline
\end{tabular}

Enseada das Garças Mangrove (MENS station)

\begin{tabular}{|c|c|c|c|c|c|c|c|c|c|c|c|c|c|c|c|}
\hline Sediment MENS 1 & 0.42 & 8.0 & 251 & 0.5 & 0.6 & 0.6 & 3.1 & 30.5 & 6.4 & 0.4 & 349.8 & 1022 & 9.5 & 33.2 & 19.3 \\
\hline Sediment MENS 2 & 0.40 & 8.5 & 445 & 0.7 & 1.1 & 0.6 & 4.7 & 21.8 & 10.7 & 1.0 & 341.2 & 1351 & 18.8 & 62.9 & 35.8 \\
\hline Sediment MENS 3 & 0.36 & 5.0 & 252 & 0.9 & 1.2 & 0.6 & 4.5 & 19.7 & 10.3 & 0.9 & 204.7 & 962 & 11.8 & 43.4 & 32 \\
\hline Leafs MENS ${ }^{a}$ & $0.02 \pm 0.02$ & & $25 \pm 2$ & & & & & & & & & & & & \\
\hline
\end{tabular}

a- The $\mathrm{Zn}$ concentrations of the leafs collected from Laguncularia Racemosa threes represents the average and the standard desviation ( $\sigma$ ) obtained from three different replicates. Each replicate was composted by leafs collected in different threes. 
Table 3. Data set of suspended particulate matter (SPM) samples.

\begin{tabular}{cccccc}
\hline & $\boldsymbol{\delta}^{\mathbf{6}} \mathbf{Z n}$ & $\begin{array}{c}\mathbf{Z n} \\
\left(\boldsymbol{\mu g . g}^{-\mathbf{1}}\right)\end{array}$ & $\begin{array}{c}\text { Conductivity } \\
\mathbf{m S / c m}\end{array}$ & $\mathbf{p H}$ & $\begin{array}{c}\text { SPM } \\
\mathbf{m g .}^{-1}\end{array}$ \\
\hline SE1 & 0.88 & 1207 & 67.24 & 8.06 & 411 \\
SE2 & 0.82 & 1455 & 60.31 & 8.68 & 413 \\
SE3 & 0.83 & 1063 & 56.20 & 8.33 & 407 \\
B1 & 0.43 & 43 & 67.38 & 7.02 & 177 \\
B2 & 0.45 & 48 & 67.45 & 8.27 & 177 \\
B3 & 0.46 & 42 & 67.52 & 8.20 & 179 \\
R1 & 0.31 & 108 & 0.08 & 7.25 & 278 \\
R2 & 0.23 & 90 & 0.27 & 6.65 & 275 \\
\hline
\end{tabular}




\section{Chapter 6}

\section{ZINC ISOTOPE COMPOSITIONS IN BIVALVE MOLLUSCS TISSUES FROM}

A BRAZILIAN ESTUARY: IMPLICATIONS FOR BIOMONITORING OF METAL CONTAMINATION

Daniel Araújo ${ }^{1-2}$; Wilson Machado ${ }^{3}$; Dominik Weiss ${ }^{4}$; Daniel S. Mulholland ${ }^{5}$; Geraldo R. Boaventura ${ }^{1}$; Jerome Viers ${ }^{2}$; Elton L. Dantas ${ }^{1}$; Marly Babinski ${ }^{6}$

1. Universidade de Brasília, Instituto de Geociências, Campus Darcy Ribeiro, L2, Asa Norte, Brasília, Distrito Federal, Brazil.

2. Géosciences Environnement Toulouse (GET-UMR 5563 CNRS, Université Paul Sabatier, IRD), 14 Edouard Belin, 31400, Toulouse, France.

3. Universidade Federal Fluminense, Departamento de Geoquímica, Campus do Valonguinho, Niterói, Rio de Janeiro, Brazil.

4. Imperial College London, Earth Science and Engineering, London, United Kingdom.

5. Universidade Federal do Tocantins, Departamento de Química Ambiental, Rua Badejós, Lote 7, Chácaras 69/72, Zona Rural, Gurupi, Tocantins, Brazil.

6. Universidade de São Paulo, Instituto de Geociências, Rua do Lago 562, Cidade Universitária, São Paulo, Brazil.

Corresponding author: Daniel F. Araújo: danielunb.ferreira@gmail.com, phone: $+556135682760$ 


\section{Abstract}

Determination of zinc $(\mathrm{Zn})$ isotopes in bivalve tissues have been explored as a novel biomonitoring tool of metal contamination, potentially capable of integrating sources, fates and bioavailability information. However, its applicability remains inconclusive. In order to investigate if the bioisotopic record of $\mathrm{Zn}$ in bivalve tissues can be used to trace sources or infer possible biogeochemical processes, we conducted a study with bivalve mollusks (Crassostrea brasiliana and Perna Perna) and suspended particulate matter (SPM) samples collected from a tropical estuary historically impacted by metallurgic activities (Sepetiba Bay, southeastern Brazil). The $\mathrm{Zn}$ isotope systematics of the SPM samples allowed the identification of end-members and mixing process in the fluvial-estuarine system. The $\mathrm{Zn}$ isotope systematics of bivalve tissues distinguished two groups: one comprising bivalve samples collected in the old metallurgic zone $\left(\delta^{66} \mathrm{Zn}_{\mathrm{JMC}}+0.49 \pm 0.06 \%, 2 \sigma, n=3\right)$ and other composed by the rest of sampling stations $(+0.83 \pm 0.10 \%, 2 \sigma, n=22)$. The bivalve isotopic signatures did not enable the identification of end-member or tendencies of mixing process, suggesting limitations to sources tracing. We found, however, that the $\mathrm{Zn}$ isotope systematics of bivalves from Sepetiba bay can be related to mechanism of bioaccumulation, i.e. uptake via dissolved and particulate phase. It is hypothesized that in the zone heavily impacted zone by old electroplating wastes, the bivalves incorporate the high levels of $\mathrm{Zn}$ in the dissolved phase though the bivalve gills by facilitated diffusion or actively pumped across the membranes. Outside this zone, due the low content of $\mathrm{Zn}$ in the dissolved phase and high Zn concentrations on suspended particulate matter, bivalves incorporate the labile $\mathrm{Zn}$ bound to particulate matter during the gut digestion. The confirmation of our hypothesis to use $\mathrm{Zn}$ isotopes as tracer of routes of bioaccumulation would be of great interest to environmental management concerning the setting of water and sediment quality criteria. 


\section{Introduction}

Bivalve molluscs are widely used as biomonitors to inform geographical and temporal trends in the bioavailabilities of metals contaminants in aquatic systems (Raibow, 1995; Oehlmann and Schulte-Oehlmann, 2003). However, their use are limited to identification of sources, while evaluation and prediction of ecological risks from metal contaminants are hampered because the metal bioaccumulation of bivalves is influenced by multiple routes of exposure (diet and solution) and geochemical effects on metal bioavailability (Wang and Fischer, 1999; Griscom et al., 2004; Wang and Rainbow, 2005; Zhou et al., 2008; Gupta and Singh, 2011; Kumar et al., 2015). To overcome these drawbacks, determination of zinc ( $\mathrm{Zn})$ isotopes in bivalve tissues have been explored as a novel biomonitoring tool of metal contamination, potentially capable of integrating sources, fates and bioavailability information (Shiel et al., 2012; Shiel et al., 2013; Petit et al., 2015).

Zinc isotopes undergo strong isotopic fractionations in industrial processes (e.g metallurgy and combustion by high-temperature or electrolysis processes), resulting in fingerprints isotopically distinct for man-made materials and byproducts from those found in nature (Sivry et al., 2008; Borrok et al., 2010; Shiel et al., 2010; Gonzalez and Weiss, 2015; Thapalia et al., 2015; Yin et al., 2015), and therefore are able to discriminate and quantify natural and anthropogenic sources, including vehicle emissions and tire wear (Gioia et al., 2008; Thapalia et al., 2015), wastewaters and sewage (Chen et al.2008; 2009), mining and metallurgy byproducts (Dogolopova et al., 2006; Mattielli et al., 2006; Weiss et al., 2007; Sivry et al., 2008; Yin et al., 2015). Zinc isotopic fractionation also occur in low temperature processes, and hence can be used to determine reactions pathways such as adsorption on organic and inorganic solid surfaces, ligand exchange and complexation, precipitation, biological uptake, and intercellular transport (Pichat et al., 2003; Stenberg et al., 2004; Weiss et al., 2005; Pokrovsky et al., 2005; Bermin et al., 2006; Gélabert et al., 2006; John et al., 2007b; Balistrieri et al., 2008; Peel et al., 2009; Fujii et al., 2011; Jouvin et al., 2012; Little et al., 2014b; Kafantaris and Borrok, 2014; Matthies et al., 2014; Dekov et al., 2014; Coutaud et al., 2014; Zhao et al., 2014; Bryan et al., 2015; Veeramani et al., 2015).

Until now, the application of $\mathrm{Zn}$ isotopes in bivalves as biomonitoring tool has been little explored and its effectiveness for sources tracing remains inconclusive. A recent study conducted with bivalves on the west coast in Canada showed homogenous 
$\mathrm{Zn}$ isotopic signatures that overlapped those of unpolluted soils, sediments and marine water (Shiel et al., 2012). In the Gironde-estuary (a site historically impacted by metallurgy) the isotopic record of oysters seemed to reflect adsorption processes associated to the Zn dissolved pool along the Maximum Turbid Zone (MTZ) rather than different Zn sources (Petit et al., 2015).

While these studies suggest that source tracing is difficult to achieve with bivalves, they also suffered from the study design. Both investigations were carried out in large, open systems with multiple anthropogenic and natural sources, point and diffusively alike, which make the task of source identification much more difficult, especially given the relatively small isotope variability of $\mathrm{Zn}$ in sources.

To a better appreciation of $\mathrm{Zn}$ isotopes as biomonitoring tool in aquatic systems, we conduct a study in a small tropical estuary system (Sepetiba Bay, southeastern Brazil). The use of this bay as model costal area are advantageous because it presents a single major anthropogenic source of $\mathrm{Zn}$ (associated to old electroplating wastes) and transport mechanisms of metal contaminants well-stablished by previous geochemical and biomonitoring studies. Zinc isotope compositions were determined in oysters (Crassostrea brasiliana), mussels (Perna Perna) and suspended particulate matter (SPM), while $\mathrm{Zn}$ concentrations were determined in water samples. In this way, this work aims to verify the applicability of $\mathrm{Zn}$ isotopes as a biomonitoring tool capable of tracing sources or indicating biogeochemical processes.

\section{Study area}

Sepetiba bay is a small semi-enclosed estuary about $519 \mathrm{~km}^{2}$ located $60 \mathrm{~km}$ south of Rio de Janeiro City (Molisani et al., 2004). It plays a strategical role as geo-economic center of Brazil, hosting a large population of metropolitan region of Rio de Janeiro City, an expressive industrial park and important harbor activity (Fig.1).

Rivers, estuaries and extensive mangroves vegetation occurs in the northern and eastern portions of the bay. The watershed of approximately $2,654 \mathrm{~km}^{2}$ is drained by rivers that crossing agricultural, industrial and urban areas. The São Francisco channel represent the main fluvial system, receipting transposed waters of a neighbor watershed located upstream and attending for over $86 \%$ of the total freshwater and most part of fluvial sediment load (Molisani et al., 2006). 
This study area was heavily impacted along the last decades by tailings (estimated at 600.000 tons) from a $\mathrm{Zn}$ electroplating plant, which was exposed to the open air for almost 50 years close the mangrove's shore (Barcellos et al., 1991, 1992, 1994). Mostly part of the wastes were lixiviated during rainfalls reaching the bay through a small marine channel located in the Saco do Engenho mangrove, considered the hot spot area (Fig.1). During the tidal cycle, large loads of in $\mathrm{Zn}$ and $\mathrm{Cd}$ arising from wastes materials were remobilized and dispersed to the inner bay via particulate or in the dissolved form (Barcellos et al., 1991, 1992, 1994). The estimative of emission rates from the electroplating wastes into the bays were about 24 t.y ${ }^{-1}$ of $\mathrm{Cd}$ and 3,660 t. $\mathrm{y}^{-1}$ for Zn, until 1997 when the plant ended its activities (Barcellos et al., 1994). High $\mathrm{Zn}$ content in sediments (Pellegati et al., 2001; Wasserman et al., 2001), oysters (Larcerda and Molisani, 2006; Rebelo et al., 2003) and brown algas (Amado Filho et al., 1999) exceeding 2000, 80000 and $800 \mu \mathrm{g} . \mathrm{g}^{-1}$ respectively have been reported along the last four decades. Despite the end of $\mathrm{Zn}$ refining activities in 1997, the continuous wastes lixiviation by pluvial waters keep the high inputs of metal loads for more than a decade later as confirmed in posterior studies (Pellegati et al., 2001; Wasserman et al., 2001; Molisani et al., 2004; Lacerda and Molisani, 2006; Marques et al., 2006; Gomes et al., 2009; Ribeiro et al., 2013). The stack of wastes was definitively removed in 2012, however, enriched- $\mathrm{Zn}$ sediment particles from the hot spot area has been continuously remobilized during tidal cycles that combined with the natural water confinement of the bay have been contributing to a major resilience of the electroplating impacts in the system.

\section{Materials and Methods}

\subsection{Sampling and sample preparation}

Oysters samples (Crassostrea Brasiliana) were collected at five different locations within the Sepetiba Bay in order to obtain a transect from the channel located in Saco do Engenho mangrove (the hot spot area of electroplating impacts, Fig.1) to close the open sea at south of the bay (point 5, Fig.1). Oyster samples from the Saco do Engenho were collected in rocks near the mouth of this channel, while the other oysters were collected in rocks of different islands spread in west side of the bay (Fig.1). About 17 to 21 individual oyster samples were collected in each one of the points 1 to 5 , accounting 
a total of 91 oyster sampled in the bay. The individual selection was based on the size, i.e., length $\mathrm{x}$ width, which average was about $3.3 \times 2.3 \mathrm{~cm}$. Mussels (Perna Perna) were found only in the point 5, where 10 individuals were collected to verify possible inherent interspecies differences on $\mathrm{Zn}$ isotope compositions. For mussels, male and female individuals were identified according the color (white for man, orange for woman) and labelled by the letters "W" and "O", respectively.

Oysters and mussels were removed from the rocks and kept in the local water under $48 \mathrm{~h}$ for depuration. Bivalve samples were rinsed with distilled water before being shucked with a stainless steel knife. Bivalve tissues were extracted with plastic spatula and rinsed with distilled and deionized water to remove particles before being stored separately individually in polyethylene little flasks and frozen for 48 hours. After, all oysters and mussels were freeze dried. For each sampling site, oysters were pooled in three different representative aliquots, each one representing a sample.

To represent the main terrestrial, marine and anthropogenic sources, water samples and suspended particulate material (SPM) were collected: i) in a transect along the São Francisco Channel, which represent the main freshwater outlet into the bay, ii) at the south mouth of the bay, where marine environment is dominant and iii) in the Saco do Engenho Channel, close the old metallurgic plant (Fig.1), where anthropogenic sources are dominant. The transect in the fluvial system (São Francisco Channel) encompassed sampling points from $\sim 7 \mathrm{~km}$ upstream until the inner bay (Fig.1). Bottles for sampling were washed overnight in sub-boiling $\mathrm{HCl}$ and then rinsed three times with pure water prior to use in the field. Water samples comeback to the laboratory preserved under low temperatures $\left(4^{\circ} \mathrm{C}\right)$ during $4 \mathrm{~h}$. At laboratory, precise volume of waters (between $150 \mathrm{ml}$ and $500 \mathrm{ml}$ ) were filtered through a $0.45 \mu \mathrm{m}$ acetate cellulose membrane previously dried and weighted. The dissolved phase were adjust to $\mathrm{pH}=2$ by adding of concentrate acid nitric and stored under $4{ }^{\circ} \mathrm{C}$ until the moment for $\mathrm{Zn}$ total concentrations determinations. Colloidal-sized particles smaller than $0.45 \mu \mathrm{m}$ are, therefore, operationally defined as solutes in this study. The filter containing the SPM samples were dried and weighed to calculate the mass of sediment.

All reagents used for the total solid samples dissolutions were prepared using > 18.2 $\mathrm{M} \Omega \mathrm{H}_{2} \mathrm{O}$ (Nanop System ${ }^{\circledR}$ ) and ultra-pure acids (Merck®) distillated by subboiling in teflon stills. The chemical procedures were performed under clean-air conditions and evaporations were conducted in clean boxes. The SPM samples and reference materials of United Survey Geological Survey (USGS) as BHVO-2, BCR-2, 
AGV-2, and National Institute of Standards and Technology (NIST) as 1616a were digested in Savillex ${ }^{\circledR}$ Teflon on a hot plate using a multiple-step acid procedure with $\mathrm{HF}, \mathrm{HNO}_{3}, \mathrm{HCl}$. The oysters samples (about $100 \mathrm{mg}$ ) were dissolved using an acid mixing ( $\mathrm{HF}, \mathrm{HCl}$ and $\mathrm{HNO}_{3}$ ) in closed vessel in a microwave system (Speedwave 4, Berghof). After total sample dissolution, the sample was transferred to Savillex ${ }^{\circledR}$ Teflon beakers dried on a hot plate, the remaining $\mathrm{HF}$ drive off by concentrate $\mathrm{HNO}_{3}$ addition and subsequently dissolved in $6 \mathrm{M} \mathrm{HCl}$, dried again and re-dissolved in $2 \mathrm{M} \mathrm{HCl}$. From this mother solution, aliquots were taken for determine $\mathrm{Zn}$ concentrations and isotopic compositions.

\section{2 $\mathrm{Zn}$ concentrations and isotope ratio analysis}

Zinc concentrations were determined by flame absorption atomic spectrometry (FAAS), model Varian AA240FS at GEOPS laboratory in the Université Paris-Sud. The calibration curves were prepared with elemental $\mathrm{Zn}$ Merck $^{\circledR}$ standards and the accuracy and precision of analysis verified with certified reference materials of United Survey Geological Survey-USGS (BHVO-2 and BCR-2 basalt), National Research Council Canada (Dorm 3 fish protein) and of SCP SCIENCE (EP-L-3 water . The experimental values agreed within of $10 \%$ of certified values. Detection limits for $\mathrm{Zn}$ were around 20 $\mu \mathrm{g} \cdot 1^{-1}$.

The sample aliquot destined to the $\mathrm{Zn}$ isotope determinations by MC-ICP-MS were processed on anion exchange chromatography to matrix separation previously the analysis. A modified procedure from that proposed by Maréchal et al. (1999) using a Bio-Rad PolyPrep columns filled with $2.0 \mathrm{ml}$ of the anion exchange resin AG-MP1 (100-200 mesh size) was used (more details in Araújo et al.2016). A Cu standard (NIST 976) was added to all samples and matched in the proportion $1: 1(300 \mu \mathrm{g} / \mathrm{ml}$ in $0.05 \mathrm{M}$ $\mathrm{HNO}_{3}$ ) to mass bias corrections. The recovery of the samples processed on the column were verified using the voltages signals on MC-ICP-MS previously calibrated for $\mathrm{Zn}$ concentration using a $\mathrm{Zn}$ Merck $^{\circledR}$ standard. All samples showed recovery close to $100 \pm 5 \%$.

$\mathrm{Zn}$ isotopic ratios were measured using the ThermoFinnigan Neptune Plus MCICP-MS at the Centro de Pesquisas Geocronológicas (CPGeo) in the São Paulo University. The introduction interface consisted of quartz glass spray chamber (cyclone + standard Scott double pass) coupled with a low flow PFA nebulizer $\left(50 \mu 1 . \mathrm{min}^{-1}\right)$. 
Masses $62(\mathrm{Ni}), 63(\mathrm{Cu}), 64(\mathrm{Zn} / \mathrm{Ni}), 65(\mathrm{Cu}), 66(\mathrm{Zn}), 67(\mathrm{Zn})$ and $68(\mathrm{Zn})$ were detected simultaneously in low resolution. Blank measurements consisted of 1 block of 10 cycles $(8 \mathrm{~s})$ while samples and standards were measured in 2 blocks of 20 cycles of $8 \mathrm{~s}$ each. Mass bias corrections were performed verifying the factor of fractionation of $\mathrm{Cu}$ and $\mathrm{Zn}(f \mathrm{Zn} / f C u)$ in the $\ln \mathrm{x} \ln$ plot in each session by the application of the exponential law (Maréchal et al.1999).

The $\mathrm{Zn}$ isotopes ratios were measured relative to an in-house $\mathrm{Zn}$ single element standard from MERCK (Lot \#9953) labeled Zn UnB standard and expressed in $\delta$ notation as below:

$$
\delta^{66} \mathrm{Zn}(\%)=\left(\frac{{ }^{66} \mathrm{Zn} /{ }^{64} \mathrm{Zn}_{\text {sample }}}{{ }^{66} \mathrm{Zn} /{ }^{64} \mathrm{Zn}_{\text {standard }}}-1\right)
$$

The final data were reported relative to the Johnson Matthey 3-0749-L (JMC) reference material, which was previously calibrated against our $\mathrm{Zn} \mathrm{UnB}$ reference material $\left(\Delta \mathrm{Zn}_{\text {JMC-UnB }}=+0.17 \%, n=30,2 \sigma \pm 0.05\right)$. Error propagations were applied to final estimation of analytical uncertainty (expressed as $2 \sigma$ ) of $\delta^{66} \mathrm{Zn}_{\text {JMC }}$ values.

For analytical control, the isotopic certified reference material Zn IRMM 3702 were measured two or three times along the session analysis yielding a $\delta^{66} \mathrm{Zn}_{\text {JMC }}$ value of $-0.27 \pm 0.06 \%(n=30,2 \sigma)$, comparable to values published previously (Satto et al.2016). In addition, USGS and NIST reference materials prepared in different replicates (full protocol including digestion, ion-exchange chromatography and twice isotopic measurements for each replicate) were used to assess the accuracy and procedural reproducibility ( $n=5$ to BHVO-2 and BCR-2 basalts, $n=1$ to AGV-2 andesite and $n=2$ to $1646 \mathrm{a}$ estuarine sediment). The $\delta^{66} \mathrm{Zn}_{\mathrm{JMC}}$ values obtained to BHVO-2, BCR2 basalts and AGV-2 andesit were $+0.25 \pm 0.10 \%$ ( $2 \sigma),+0.25 \pm 0.08 \%$ o $(2 \sigma)$ and +0.29 $\pm 007(2 \sigma)$, respectively. All these results agree well with those reported in the literature for silicate rocks (Chapman et al., 2006; Herzog et al., 2009; Moynier et al., 2009; Chen et al., 2013; Sossi et al., 2015). The average of external reproducibility of unknowing samples (SPM, oysters and mussels) was $\pm 0.07 \%$ o $(2 \sigma, n=36)$ and this value were considered the external reproducibility of the all methodological procedure. 


\subsection{Statistical analysis}

Comparison of on $\mathrm{Zn}$ concentrations and $\mathrm{Zn}$ isotope compositions between the different sampling sites were verified by statistical testes using the SPPS $®$ software v.18.0 (IBM®, Armonk, NY, USA). The normality distribution of data were verified with Kolmogorov-Smirnov and Shapiro-Wilk tests, while Levene's test was applied to check the homogeneity of variances. One-way ANOVA and test $t$ were applied to data normal distributed. If data deviate from the normal distribution or fall in Levene's test, the Welch ANOVA were used instead of a one-way ANOVA.

\section{Results}

\section{1 $\mathrm{Zn}$ particulate isotopic compositions and $\mathrm{Zn}$ dissolved concentrations}

All dataset of $\mathrm{Zn}$ isotope compositions and $\mathrm{Zn}$ concentrations of water and SPM samples are summarized in the Table 1 . The $\delta^{66} \mathrm{Zn}_{\mathrm{JMC}}$ values of the SPM samples vary between +0.15 and $+0.95 \%$ (Table 1, Fig.2 and Fig.3). The samples collected around the old metallurgic zone (Saco do Engenho, Fig.1) show higher Zn concentrations (325 to $\left.2,339 \mu \mathrm{g} \cdot \mathrm{g}^{-1}\right)$ and isotope compositions $(+0.87$ to $+0.95 \%$ o) when compared to the samples from the bay mouth area and the San Francisco channel. At the south bay area, $\mathrm{Zn}$ concentrations range from 60 to $629 \mu \mathrm{g} \cdot \mathrm{g}^{-1}$ and the isotope compositions vary from +0.44 to $+0.52 \%$. At San Francisco channel, a clear enrichment of heavy isotopes on the SPM, from +0.15 to +0.53 , can be observed from upstream toward the channel mouth at the Sepetiba bay. Along the fresh and marine waters mixture, a positive correlation $\left(\mathrm{R}^{2}=0.80\right)$ is noticed between electrical conductivity and $\mathrm{Zn}$ isotope composition (Fig.3).

The dissolved $\mathrm{Zn}$ concentrations vary from 66 to 3,384 $\mu \mathrm{g} . \mathrm{L}^{-1}$, with the highest concentration detected again near the old metallurgic zone (Saco do Engenho). The sampling site MZ1 exceeded the Brazilian Legislation threshold value for marine water of $170 \mu \mathrm{g} . \mathrm{L}^{-1}$ (CONAMA, 357/2005). At the south bay area and the San Francisco channel, dissolved $\mathrm{Zn}$ concentration were low and in most cases were below the analytical limits of detection $\left(20 \mu \mathrm{g} . \mathrm{L}^{-1}\right)$. 


\section{2 $\mathrm{Zn}$ isotopic compositions of oysters and mussels}

All dataset of $\mathrm{Zn}$ isotope compositions and $\mathrm{Zn}$ concentrations of oyster and mussels samples are summarized in the Table 2. Zinc concentrations of oysters tissues in general decrease along the transect from the hotspot of metallurgic contamination (Saco do Engenho) to the south bay area, i.e., from the first sampling site (P1) to the last one (P5) (Table 2). In the old metallurgic zone (Saco do Engenho), the $\mathrm{Zn}$ concentration of oyster were 3-6 fold higher than the other sampling sites located throughout Sepetiba bay (Fig.4). The average of $\mathrm{Zn}$ isotope compositions of oysters samples from Saco do Engenho is $+0.49 \pm 0.06 \%$ o $(2 \sigma, n=3)$, contrasting with the isotope composition of other oyster samples collected along the island's bay (P2 to P5 sites, Fig.4), which present average of $+0.85 \pm 0.06 \%$ o $(2 \sigma, n=12)$. The averages of oysters from P2 to P5 sites are statistically equal (Welch test, $p>0.05$ ).

Mussels have lower $\mathrm{Zn}$ concentrations than oysters collected at the same sampling site (P5) with an average of $136 \pm 29 \mu \mathrm{g} \cdot \mathrm{g}^{-1}(1 \sigma, n=10)$. The $\mathrm{Zn}$ isotope compositions of mussels Perna Perna are about $+0.82 \pm 0.14 \%$ ( $2 \sigma, n=10$ samples, Fig.4), which are statiscally equal (teste $t, p>0.05$ ) to oysters collected in the island's bay (P2 to P5 points). The average of $\mathrm{Zn}$ concentrations of male (120 $\pm 11 \mu \mathrm{g} \cdot \mathrm{g}^{-1}, 1 \sigma, n$ =6) and female (161 $\left.\pm 31 \mu \mathrm{g} \cdot \mathrm{g}^{-1}, 1 \sigma, n=4\right)$ were statiscally different (test $\left.t, p<0.05\right)$, but not for $\mathrm{Zn}$ isotope compositions (test $\mathrm{t}, p>0.05$ ).

\section{Discussion}

\subsection{The $\mathrm{Zn}$ isotopic signatures of sediment plume in the fluvial-estuarine system}

The $\delta^{66} \mathrm{Zn}_{\mathrm{JMC}}$ values of SPM samples from the impacted area of Saco do Engenho fell within the range of heavy isotopic signatures associated to metallurgic wastes and effluents reported in previous studies that vary from +0.18 to $+1.49 \%$ (Sivry et al., 2008; Juillot et al., 2011; Yin et al., 2015). These results seems to reflect an isotopic record of the contamination by the old electroplating wastes and endorse previous models of $\mathrm{Zn}$ isotopic fractionation during the high-temperature and electroplating process, which points to a formation of solid wastes enriched in the heavy isotope (Kavner et al., 2008; Borrok et al., 2010; Shiel et al., 2010; Gonzalez and Weiss, 2015; Black et al., 2014). 
The great $\mathrm{Zn}$ concentrations in the dissolved and particulate phase from samples collected in the old Metallurgic zone indicate a high remobilization of $\mathrm{Zn}$-enriched sediments during low tides and point out the fact that this source is still a significant $\mathrm{Zn}$ supplier to the Sepetiba bay system, despite the end of metallurgic activities (1997) and wastes removal (2012).

In the transect from the São Francisco channel to the inner bay, $\delta^{66} \mathrm{Zn}_{\text {JMC values }}$ increase accompanying the increasing of salinity (conductivity), from +0.15 to $+0.53 \%$ o (Fig.3), and $\mathrm{Zn}$ concentrations increase from 66 to $247 \mu \mathrm{g} . \mathrm{L}^{-1}$. These results likely reflect the mixture between the $\mathrm{Zn}$ continental and the $\mathrm{Zn}$ metallurgic-anthropogenic during the tidal cycles. The heavier isotope compositions of the sample located at final of the fluvial transect (R5) indicate the old metallurgic zone as main source of $\mathrm{Zn}$ close in the inner bay. The $\mathrm{Zn}$ isotope compositions of upstream samples of the fluvial system, R1 (+0.15\%) and R2 (+0.19\%o), overlap the typical signatures of diffuse sources as sewage and wastewaters $(+0.10 \%$, Chen et al., 2009), traffic emission (+0.10\%oThapalia et al., 2015) and manufactured Zn products Zn (+0.22 $\pm 0.06 \%$, John et al., 2007a; Shiel et al., 2010; Yin et al., 2015). Thus, it seems that the continental Zn encompasses contributions of both natural and anthropogenic sources. The first is related to the rock and soil weathering and the second, to the intense urbanization, industrialization and urban sprawl of the watershed of Sepetiba bay.

At south bay area, under a marine environment, the SPM of SB1 and SB3 samples show low concentrations and $\delta^{66} \mathrm{Zn}_{\mathrm{JMC}}$ values heavier than river upstream samples (R1 and R2). A possible explanation could be associated to marine carbonate contributions, which tend to present heavier isotope compositions (Kunzmann et al., 2012). The high $\mathrm{Zn}$ concentration and the heavy $\delta^{66} \mathrm{Zn}_{\mathrm{JMC}}$ value of $+0.62 \%$ of the sample SB2 seem to reflect an anthropogenic $\mathrm{Zn}$ origin from the metallurgic impacted zone. The SB2 sample evidences the transport of contaminants in long distances induced by the hydrodynamics characteristics of the system and due to the continuous processes of deposition and resuspension of sediment particles (Barcellos et al., 1997). The dispersion of plume sediments shows a pattern of distribution towards west, leading the most fine-grained and colloids rapidly to cross the bay with high load of metal, while coarser sediments tends to be deposited in the northeastern shore (Patchineelam et al., 2011; Montezuma, 2013). 


\subsection{Tracing sources with $\mathrm{Zn}$ isotope compositions of bivalves tissues}

A spatial analysis of the sampling sites (from P1 to P5) reveals the reduction of $\mathrm{Zn}$ concentrations in oyster tissues with the distance from the old metallurgic zone. Similar tendency were obtained previously by Rebelo et al.(2003), who concluded that the temporal and spatial $\mathrm{Zn}$ concentrations changes are directly related to major or lower influence of metallurgic-anthropogenic $\mathrm{Zn}$ exported to the bay. In comparison to this last study, the $\mathrm{Zn}$ concentrations decreased eight to four fold probably due to the closure of metallurgic activities in 1997 and the removal of wastes from the watershed in 2012.

However, the $\delta^{66} \mathrm{Zn}_{\mathrm{JMC}}$ values of bivalve tissues of Sepetiba bay were not correlated to $\mathrm{Zn}$ concentrations nor associated to SPM samples. In the metallurgic impacted zone (Saco do Engenho mangrove), we find a strong significant isotopic

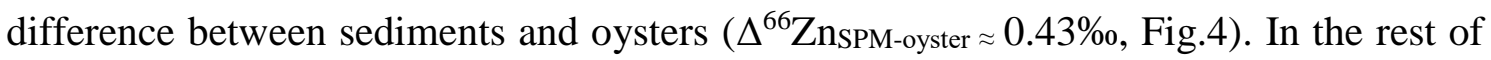
the bay, the $\delta^{66} \mathrm{Zn}_{\text {JMC }}$ values of oysters and mussels from P2 to P5 sampling sites clustered around $+0.83 \pm 0.10 \%$, not showing any spatial tendency toward lighter or heavier values. Thus, unlike the SPM samples, $\mathrm{Zn}$ isotopes compositions of bivalve tissues did not enable the identification of end-member or tendencies of mixing process. However, it is important to note an apparent matching between the $\delta^{66} \mathrm{Zn}_{\mathrm{JMC}}$ values of oysters and mussels from P2 to P5 (+0.83 $\pm 0.10 \%, 2 \sigma, n=22)$ and the Zn-enriched SPM collected in the old metallurgic zone $(+0.92 \pm 0.04 \%, 2 \sigma, n=3)$.

Moreover, oysters (Crassostrea Brasiliana) and mussels (Perna Perna) collected at same sampling site (P5) showed Zn isotope compositions statistically equals, despite the considerable difference on $\mathrm{Zn}$ concentrations. This suggests that differences on physiological processes concerning the controlling of uptaking, accumulation and excretion of trace metals do not influence significantly their isotope compositions. Male and female mussels, in similar way, presented statiscally different Zn concentrations as reported in previous studies (La Touche and Mix, 1982; Roméo et al., 2012), but had also $\delta^{66} \mathrm{Zn}_{\mathrm{JMC}}$ values statistically equals, denoting no relation between sex and $\mathrm{Zn}$ isotope compositions.

Our results are lined up with previous findings of Petit et al.(2015) in the Gironde estuary, who verified also a lack of correspondence between $\mathrm{Zn}$ isotopic signatures of bivalve tissues and sources. These authors suggested that oysters of this estuary incorporate the $\mathrm{Zn}$ of dissolved phase, which undergo constant isotope fractionations associated to adsorption processes on solid surfaces. Thus, the sources 
signatures are overprinted and the bioisotopic record of $\mathrm{Zn}$ in the tissues reflect the geochemical processes that took place along the zone of fresh and marine waters mixing.

Such mechanism fits well to explain the lighter isotope compositions found in the oysters from the contaminated area by the old metallurgic activity. In the small channel inside the mangrove of Saco do Engenho (Fig.1), the dissolved phase presented anomalous concentrations above $3,000 \mu \mathrm{g} . \mathrm{L}^{-1}$, indicating a probably high bioavailability of $\mathrm{Zn}$ associated to its forms as ion free or chloride complexes (Ahlf et al., 2009). Hence a large $\mathrm{Zn}$ incorporation via dissolved phase could be expected. Despite we were not able to measure the isotope composition of this phase to confirm it, experimental and empirical studies suggest that $\mathrm{Zn}$ adsorption on solid phases leads the dissolved pool toward lighter Zn isotope compositions (Pokrovisky et al., 2005; Gélabert et al., 2006; Balistrieri et al., 2008; Little et al., 2014; Bryan et al., 2015), which magnitude tend to be stronger in mediums of high ionic strength and variable $\mathrm{pH}$ ranges (Bryan et al.,2015; Szynkiewicz and Borrok, 2016), such as occurs in estuaries environment. Therefore, the large difference between oyster tissues and the suspended particulate matter in the old metallurgic zone $\left(\Delta_{\text {SPM-Oyster }} \approx 0.43 \%\right.$ ) could be explained by the $\mathrm{Zn}$ bioaccumulation mechanism via dissolved phase, which would be strongly fractionated in relation to sediment pool due to changes of $\mathrm{pH}$ and salinity during tidal cycles. The absorption pathway of dissolved forms as free or complexed ions occurs in the gills where these elements can be passively accumulated by facilitated diffusion or actively pumped across the membranes (Carpene and George, 1981; Goslim, 2003; Wang and Rainbow, 2005). The free (hydrate)-metal ions are recognized as the most bioavailable and toxic form, while inorganic and organic complexes can also be potentially bioavailable (Anderson et al., 1984; Milero, 2001).

In the others sampling sites (from $\mathrm{P} 2$ to $\mathrm{P} 5$ ), $\mathrm{Zn}$ isotope compositions were heavier and practically equals: $+0.85 \pm 0.06 \%$ o $(2 \sigma, n=12)$ to oysters and $+0.82 \pm 0.14 \%$ o $(2 \sigma, n=10$ samples) to mussels. This suggest a common mechanism for $\mathrm{Zn}$ bioaccumulation by the bivalves in these areas, different from the oysters collected in the old metallurgic zone (P1). In the areas outside the hotspot of contamination (Saco do Engenho), Zn concentrations of dissolved phase decrease to values below our limit of detection $\left(20 \mu \mathrm{g} . \mathrm{L}^{-1}\right.$ for $\left.\mathrm{Zn}\right)$, which makes the particulate phase the probable main route of metal transference to the biota of Sepetiba bay. Previous studies observed expressive $\mathrm{Zn}$ concentrations ( $~ 80 \%$ wt.) in the weakly bound fraction extracted with 0.1 mol.L ${ }^{-1}$ 
$\mathrm{HCl}$. These high amounts of $\mathrm{Zn}$ in labile fractions of sediments are potentially bioavailable to the biota (Lacerda et al., 1987), since metals can undergo desorption at acid $\mathrm{pH}$ in the bivalve gut and be incorporated by the gut epithelial cells (Griscom et al., 2000; Griscom and Fishier, 2004; Birch and Hogg, 2011). Alternatively, metal transference via trophic chain may be also an important factor taking into account the high $\mathrm{Zn}$ concentrations found in brown algae from Sepetiba bay $\left(\sim 800 \mu \mathrm{g} \cdot \mathrm{g}^{-1}\right.$, Amado Filho et al., 1999).

As the labile $\mathrm{Zn}$ potentially bioavailable comes predominantly in the major anthropogenic source, i.e, the old electroplating wastes, it is plausible that bivalve tissues will incorporate the $\mathrm{Zn}$ isotopic signature of this source (Lacerda et al., 1987). Based on these hypothesis, we could explain: i) why the isotope compositions of oysters and mussels in the inner bay are very similar amongst the sampling sites from P2 to P5 $(+0.83 \pm 0.10 \%, 2 \sigma, n=22)$ and ii) why they are isotopically similar to the SPM samples from the old metallurgic zone ( $+0.92 \pm 0.04 \%$, $2 \sigma, \mathrm{n}=3)$. A general model of $\mathrm{Zn}$ isotopic fractionation involving possible routes of bioaccumulation in bivalves of Sepetiba bay is presented in the Fig.5

\section{Conclusions}

The $\mathrm{Zn}$ isotope systematics of the SPM samples allowed the identification of endmembers and mixing process in the fluvial-estuarine system. The SPM heavily contaminated by the old electroplating wastes presented $\delta^{66} \mathrm{Zn}_{\mathrm{JMC}}$ values of +0.92 $\pm 0.04 \%$ o $(2 \sigma, n=3)$, which are similar to reported values for metallurgical wastes and effluents (Yin et al., 2015). Continental $\mathrm{Zn}$ brought by the main river of the bay showed lighter $\delta^{66} \mathrm{Zn}_{\text {JMC }}$ values of +0.15 and $+0.19 \%$, indicating probable anthropogenic diffuse sources contributions (Chen et al., 2009; Thapalia et al., 2015).

The $\mathrm{Zn}$ isotope systematics of bivalve tissues indicated two distinct groups: one representing the hotspot area of the old metallurgic zone with $\delta^{66} \mathrm{Zn}_{\text {JMC }}$ values of +0.49 $\pm 0.06 \%$ o $(2 \sigma, n=3)$ and other comprising the rest of sampling stations with $\delta^{66} \mathrm{Zn}_{\mathrm{JMC}}$ values around $+0.83 \pm 0.10 \%$ o $(2 \sigma, n=22)$. Unlike SPM samples, the $\mathrm{Zn}$ isotope systematics of bivalves were not associated to end-member or mixing processes. Instead, bioisotopic record of $\mathrm{Zn}$ in bivalve tissues seems reflect different routes of bioaccumulation: in the metallurgic impacted zone (P1), high abundance of $\mathrm{Zn}$ in the dissolved phase (> 3,000 $\left.\mu \mathrm{g} . \mathrm{L}^{-1}\right)$ constitute probably the main route of bioaccumulation 
to bivalves, while in the rest of the bay (P2 to P5 sites), the particulate route likely predominates through the ingestion, digestion and incorporation of the $\mathrm{Zn}$ bound to labile fraction of contaminated particles. We suggest that most part of the labile $\mathrm{Zn}$ bound to the particles preserves the isotope signature of the old electroplating wastes.

In conclusion, our study indicates that $\mathrm{Zn}$ isotopes in bivalve tissues for identification of natural and anthropogenic sources are limited. However, our hypothesis opens new possibilities to use $\mathrm{Zn}$ isotopes as tracer of routes of bioaccumulation. This would be of great interest to environmental management, concerning the setting of water and sediment quality criteria. However, future $\mathrm{Zn}$ isotope compositions determinations on the dissolved and labile phase of sediments are required to confirm our hypothesis. In addition, we recommend controlled laboratorial experiments in order to unveil the $\mathrm{Zn}$ isotope fractionation associated to the different routes of bioaccumulation and $\mathrm{Zn}$ speciation.

\section{Acknowledges}

The authors acknowledge the financial support and grants provided by $\mathrm{CNPq}$ (Brazilian Research Council, grant numbers: 161944/2012-4 and 211238/2014-7).

\section{References}

Ahlf W., Drost W. and Heise S. (2009) Incorporation of metal bioavailability into regulatory frameworks - metal exposure in water and sediment. J Soils Sediments 9, 411-419.

Amado Filho G., Andrade L., Karez C., Farina M. and Pfeiffer W. (1999) Brown algae species as biomonitors of $\mathrm{Zn}$ and $\mathrm{Cd}$ at Sepetiba Bay, Rio de Janeiro, Brazil. Marine Environmental Research 48, 213-224.

Anderson D., Lively J. and Vaccaro R. (1984) Copper complexation during spring phytoplankton blooms in coastal waters. Journal of Marine Research 42, 677-695.

Araújo D., Boaventura G., Viers J., Mulholland D., Weiss D., Araújo D., Lima B., Ruiz I., Machado W., Babinski M. and Dantas E. (2016) Ion Exchange Chromatography and Mass Bias Correction for Accurate and Precise Zn Isotope Ratio Measurements in Environmental Reference Materials by MC-ICP-MS. Journal of the Brazilian Chemical Society.

Barcellos C. and Lacerda L. (1994) Cadmium and zinc source assessment in the Sepetiba Bay and basin region. Environmental Monitoring and Assessment 29, 183-199.

Barcellos C., Rezende C. and Pfeiffer W. (1991) Zn and Cd production and pollution in a Brazilian coastal region. Marine Pollution Bulletin 22, 558-561.

Barcellos C., Lacerda L.D., Rezende C.E., Machado J. (1992). Arsenic contamination in a coastal environment affected by a zinc smelting plant (Sepetiba Bay, Brazil). In: Proceedings of the International Seminar on Arsenic in the Environment its Incidence and Health, Universidad de Chile, Santiago, pp. 59-62.

Balistrieri L., Borrok D., Wanty R. and Ridley W. (2008) Fractionation of $\mathrm{Cu}$ and Zn isotopes during 
adsorption onto amorphous $\mathrm{Fe}(\mathrm{III})$ oxyhydroxide: Experimental mixing of acid rock drainage and ambient river water. Geochimica et Cosmochimica Acta 72, 311-328.

Bermin J., Vance D., Archer C. and Statham P. (2006) The determination of the isotopic composition of $\mathrm{Cu}$ and $\mathrm{Zn}$ in seawater. Chemical Geology 226, 280-297.

Birch G. and Hogg T. (2011) Sediment quality guidelines for copper and zinc for filter-feeding estuarine oysters?. Environmental Pollution 159, 108-115.

Bryan A., Dong S., Wilkes E. and Wasylenki L. (2015) Zinc isotope fractionation during adsorption onto Mn oxyhydroxide at low and high ionic strength. Geochimica et Cosmochimica Acta 157, 182-197.

Carpene E., George, S.G. 1981. Adsorption of cadmium by gills of Mytilus edulis. Mol. Physiol. 1, 2324.

Costas-Rodríguez M., Van Heghe L. and Vanhaecke F. (2014) Evidence for a possible dietary effect on the isotopic composition of $\mathrm{Zn}$ in blood via isotopic analysis of food products by multi-collector ICP-mass spectrometry. Metallomics 6, 139-146.

Chen H., Savage P., Teng F., Helz R. and Moynier F. (2013) Zinc isotope fractionation during magmatic differentiation and the isotopic composition of the bulk Earth. Earth and Planetary Science Letters 369-370, 34-42.

Chen J., Gaillardet J., Louvat P. and Huon S. (2009) Zn isotopes in the suspended load of the Seine River, France: Isotopic variations and source determination. Geochimica et Cosmochimica Acta 73, 40604076.

Chen J., Gaillardet J. and Louvat P. (2008) Zinc Isotopes in the Seine River Waters, France: A Probe of Anthropogenic Contamination. Environmental Science \& Technology 42, 6494-6501.

CONAMA 357/2005 (2005) Resolução no 357 de março de 2005. Conselho Nacional do Meio Ambiente. Ministério do Meio Ambiente, Brasil.

Coutaud A., Meheut M., Viers J., Rols J. and Pokrovsky O. (2014) Zn isotope fractionation during interaction with phototrophic biofilm. Chemical Geology 390, 46-60.

David LaTouche Y. and Mix M. (1982) The effects of depuration, size and sex on trace metal levels in bay mussels. Marine Pollution Bulletin 13, 27-29.

Dekov V., Vanlierde E., Billström K., Garbe-Schönberg C., Weiss D., Gatto Rotondo G., Van Meel K., Kuzmann E., Fortin D., Darchuk L. and Van Grieken R. (2014) Ferrihydrite precipitation in groundwater-fed river systems (Nete and Demer river basins, Belgium): Insights from a combined Fe-Zn-Sr-Nd-Pb-isotope study. Chemical Geology 386, 1-15.

Dolgopolova A., Weiss D., Seltmann R., Kober B., Mason T., Coles B. and Stanley C. (2006) Use of isotope ratios to assess sources of $\mathrm{Pb}$ and $\mathrm{Zn}$ dispersed in the environment during mining and ore processing within the Orlovka-Spokoinoe mining site (Russia). Applied Geochemistry 21, 563-579.

Fujii T., Moynier F., Pons M. and Albarède F. (2011) The origin of Zn isotope fractionation in sulfides. Geochimica et Cosmochimica Acta 75, 7632-7643.

Gélabert A., Pokrovsky O., Viers J., Schott J., Boudou A. and Feurtet-Mazel A. (2006) Interaction between zinc and freshwater and marine diatom species: Surface complexation and $\mathrm{Zn}$ isotope fractionation. Geochimica et Cosmochimica Acta 70, 839-857.

Gioia S., Weiss D., Coles B., Arnold T. and Babinski M. (2008) Accurate and Precise Zinc Isotope Ratio Measurements in Urban Aerosols. Analytical Chemistry 80, 9776-9780.

Gomes F. de C., Godoy J., Godoy M., Lara de Carvalho Z., Tadeu Lopes R., Sanchez-Cabeza J., Drude de Lacerda L. and Cesar Wasserman J. (2009) Metal concentrations, fluxes, inventories and chronologies in sediments from Sepetiba and Ribeira Bays: A comparative study. Marine Pollution Bulletin 59, 123-133.

Gosling E. (2003) Bivalve molluscs. Fishing News Books, Oxford.

Griscom S. and Fisher N. (2004) Bioavailability of sediment-bound metals to marine bivalve molluscs: An overview. Estuaries 27, 826-838.

Griscom, S. B., Fisher, N. S. and Luoma, S. N. 2000 Geochemical influences on assimilation of sedimentbound metals in clams and mussels.Environmental Science and Technology34,91-99.

Herzog G., Moynier F., Albarède F. and Berezhnoy A. (2009) Isotopic and elemental abundances of 
copper and zinc in lunar samples, Zagami, Pele's hairs, and a terrestrial basalt. Geochimica et Cosmochimica Acta 73, 5884-5904.

Kafantaris F. and Borrok D. (2014) Zinc isotope fractionation during surface adsorption and intracellular incorporation by bacteria. Chemical Geology 366, 42-51.

John S., Genevieve Park J., Zhang Z. and Boyle E. (2007a) The isotopic composition of some common forms of anthropogenic zinc. Chemical Geology 245, 61-69.

John S., Geis R., Saito M. and Boyle E. (2007b) Zinc isotope fractionation during high-affinity and lowaffinity zinc transport by the marine diatom Thalassiosira oceanica. Limnol. Oceangr. 52, 27102714.

Jouvin D., Weiss D., Mason T., Bravin M., Louvat P., Zhao F., Ferec F., Hinsinger P. and Benedetti M. (2012) Stable Isotopes of $\mathrm{Cu}$ and $\mathrm{Zn}$ in Higher Plants: Evidence for $\mathrm{Cu}$ Reduction at the Root Surface and Two Conceptual Models for Isotopic Fractionation Processes. Environmental Science \& Technology 46, 2652-2660.

Marques A., Monna F., da Silva Filho E., Fernex F. and Fernando Lamego Simões Filho F. (2006) Apparent discrepancy in contamination history of a sub-tropical estuary evaluated through $210 \mathrm{~Pb}$ profile and chronostratigraphical markers. Marine Pollution Bulletin 52, 532-539.

Marèchal C., Télouk P. and Albarède F. (1999) Precise analysis of copper and zinc isotopic compositions by plasma-source mass spectrometry. Chemical Geology 156, 251-273.

Matthies R., Krahé L. and Blowes D. (2014) Zinc stable isotope fractionation upon accelerated oxidative weathering of sulfidic mine waste. Science of the Total Environment 487, 97-101.

Mattielli N., Rimetz J., Petit J., Perdrix E., Deboudt K., Flament P. and Weis D. (2006) Zn-Cu isotopic study and speciation of airborne metal particles within a $5-\mathrm{km}$ zone of a lead/zinc smelter. Geochimica et Cosmochimica Acta 70, A401.

Millero F. (2001) Speciation of metals in natural waters. Geochem. Trans. 2, 56.

Molisani, M.M., Marins, R.V., Machado, W., Paraquetti, H.H.M., Bidone, E.D., Lacerda, L.D. (2004) Environmental changes in Sepetiba Bay, SE Brazil. Regional Environmental Change 4, 17-27.

Molisani M., Kjerfve B., Silva A. and Lacerda L. (2006) Water discharge and sediment load to Sepetiba Bay from an anthropogenically-altered drainage basin, SE Brazil. Journal of Hydrology 331, 425433.

Oehlmann J. and Schulte-Oehlmann U. (2003) Molluscs as bioindicators In: Bioindicators \& biomonitors (eds. Markert B., Breure A. and Zechmeister H), Elsevier, Amsterdam.

Patchineelam S., Sanders C., Smoak J., Zem R., Oliveira G. and Patchineelam S. (2011) A historical evaluation of anthropogenic impact in coastal ecosystems by geochemical signatures. J. Braz. Chem. Soc. 22, 120-125.

Peel K., Weiss D. and Siggc L. (2009) Zinc isotope composition of settling particles as a proxy for biogeochemical processes in lakes: Insights from the eutrophic Lake Greifen, Switzerland. Limnol. Oceanogr. 54, 1699-1708.

Petit J., Schäfer J., Coynel A., Blanc G., Chiffoleau J., Auger D., Bossy C., Derriennic H., Mikolaczyk M., Dutruch L. and Mattielli N. (2015) The estuarine geochemical reactivity of Zn isotopes and its relevance for the biomonitoring of anthropogenic $\mathrm{Zn}$ and $\mathrm{Cd}$ contaminations from metallurgical activities: Example of the Gironde fluvial-estuarine system, France. Geochimica et Cosmochimica Acta 170, 108-125.

Pellegatti F., Figueiredo A. and Wasserman J. (2001) Neutron Activation Analysis Applied to the Determination of Heavy Metals and Other Trace Elements in Sediments from Sepetiba Bay (RJ), Brazil. Geostandards and Geoanalytical Research 25, 307-315.

Pichat S., Douchet C. and Albarède F. (2003) Zinc isotope variations in deep-sea carbonates from the eastern equatorial Pacific over the last $175 \mathrm{ka}$. Earth and Planetary Science Letters 210, 167-178.

Pokrovsky O., Viers J. and Freydier R. (2005) Zinc stable isotope fractionation during its adsorption on oxides and hydroxides. Journal of Colloid and Interface Science 291, 192-200.

Ribeiro A., Figueiredo A., Santos J., Dantas E., Cotrim M., Cesar Lopes Figueira R., V. Silva Filho E. and Cesar Wasserman J. (2013) Combined SEM/AVS and attenuation of concentration models for the assessment of bioavailability and mobility of metals in sediments of Sepetiba Bay (SE Brazil). 
Marine Pollution Bulletin 68, 55-63.

Roméo M., Sidoumou Z. and Gnassia-Barelli M. (2000) Heavy Metals in Various Molluscs from the Mauritanian Coast. Bulletin of Environmental Contamination and Toxicology 65, 269-276.

Shiel A., Weis D., Cossa D. and Orians K. (2013) Determining provenance of marine metal pollution in French bivalves using $\mathrm{Cd}, \mathrm{Zn}$ and $\mathrm{Pb}$ isotopes. Geochimica et Cosmochimica Acta 121, 155-167.

Shiel A., Weis D. and Orians K. (2012) Tracing cadmium, zinc and lead sources in bivalves from the coasts of western Canada and the USA using isotopes. Geochimica et Cosmochimica Acta 76, 175190.

Shiel A., Weis D. and Orians K. (2010) Evaluation of zinc, cadmium and lead isotope fractionation during smelting and refining. Sci. Total Environ. 408, 2357-2368.

Sivry Y., Riotte J., Sonke J., Audry S., Schafer J., Viers J., Blanc G., Freydier R. And Dupre B. (2008) Zn isotopes as tracers of anthropogenic pollution from $\mathrm{Zn}$-ore smelters The Riou Mort-Lot River system. Chemical Geology 255, 295-304.

Sossi P., Halverson G., Nebel O. and Eggins S. (2014) Combined Separation of Cu, Fe and Zn from Rock Matrices and Improved Analytical Protocols for Stable Isotope Determination. Geostandards and Geoanalytical Research 39, 129-149.

Stenberg A., Andrén H., Malinovsky D., Engström E., Rodushkin I. and Baxter D. (2004) Isotopic Variations of Zn in Biological Materials. Analytical Chemistry 76, 3971-3978.

Szynkiewicz A. and Borrok D. (2016) Isotope variations of dissolved $\mathrm{Zn}$ in the Rio Grande watershed, USA: The role of adsorption on Zn isotope composition. Earth and Planetary Science Letters 433, 293-302.

Thapalia A., Borrok D., Van Metre P. and Wilson J. (2015) Zinc Isotopic Signatures in Eight Lake Sediment Cores from Across the United States. Environmental Science \& Technology 49, 132-140.

Wang W. and Fisher N. (1999) Delineating metal accumulation pathways for marine invertebrates. Science of The Total Environment 237-238, 459-472.

Wang W. and Rainbow P. (2005) Influence of metal exposure history on trace metal uptake and accumulation by marine invertebrates. Ecotoxicology and Environmental Safety 61, 145-159.

Wasserman J., Figueiredo A., Pellegatti F. and Silva-Filho E. (2001) Elemental composition of sediment cores from a mangrove environment using neutron activation analysis. Journal of Geochemical Exploration 72, 129-146.

Weiss D., Mason T., Zhao F., Kirk G., Coles B. and Horstwood M. (2004) Isotopic discrimination of zinc in higher plants. New Phytologist 165, 703-710.

Weiss D., Rausch N., Mason T., Coles B., Wilkinson J., Ukonmaanaho L., Arnold T. and Nieminen T. (2007) Atmospheric deposition and isotope biogeochemistry of zinc in ombrotrophic peat. Geochimica et Cosmochimica Acta 71, 3498-3517.

Weiss D., Mason T., Zhao F., Kirk G., Coles B. and Horstwood M. (2004) Isotopic discrimination of zinc in higher plants. New Phytologist 165, 703-710.

Yin N., Sivry Y., Benedetti M., Lens P. and van Hullebusch E. (2016) Application of Zn isotopes in environmental impact assessment of $\mathrm{Zn}-\mathrm{Pb}$ metallurgical industries: A mini review. Applied Geochemistry 64, 128-135.

Zhao Y., Vance D., Abouchami W. and de Baar H. (2014) Biogeochemical cycling of zinc and its isotopes in the Southern Ocean. Geochimica et Cosmochimica Acta 125, 653-672.

Zhou Q., Zhang J., Fu J., Shi J. and Jiang G. (2008) Biomonitoring: An appealing tool for assessment of metal pollution in the aquatic ecosystem. Analytica Chimica Acta 606, 135-150.

Zuykov M., Pelletier E. and Harper D. (2013) Bivalve mollusks in metal pollution studies: From bioaccumulation to biomonitoring. Chemosphere 93, 201-208. 
Table 1. Suspended particulate matter (SPM) and water data set.

\begin{tabular}{|c|c|c|c|c|c|c|c|c|c|c|}
\hline 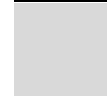 & $\begin{array}{l}Z n_{S P M} \\
\mu g \cdot g^{-1}\end{array}$ & $\begin{array}{l}Z_{n_{\text {Diss }}}{ }^{*} \\
\mu g \cdot L^{-1}\end{array}$ & $\delta^{6664} Z_{\text {JMC }}$ & $2 \sigma$ & $\delta^{6864} \mathrm{Zn}_{\text {JMC }}$ & $2 \sigma$ & $n$ & $\begin{array}{l}\text { SPM } \\
\mathrm{mg} \cdot \mathrm{L}^{-1}\end{array}$ & $\begin{array}{c}\text { Conductivity } \\
\mathrm{mS} \cdot \mathrm{cm}^{-1}\end{array}$ & $\mathrm{pH}$ \\
\hline \multicolumn{11}{|c|}{ Saco do Engenho (Old metallurgic zone) } \\
\hline MZ1 & 2339 & 3384 & 0.87 & 0.05 & 1.62 & 0.10 & $2(1)$ & 25 & 57 & 7.3 \\
\hline MZ2 & 1169 & 85 & 0.93 & 0.10 & 1.88 & 0.09 & $2(1)$ & 21 & 55 & 7.8 \\
\hline MZ3 & 325 & 66 & 0.95 & 0.05 & 1.87 & 0.09 & $2(1)$ & 59 & 51 & 7.8 \\
\hline \multicolumn{11}{|c|}{ River - SF Channel } \\
\hline $\mathrm{R} 1$ & 66 & 87 & 0.15 & 0.09 & 0.32 & 0.15 & $4(2)$ & 22 & 1.5 & 6.9 \\
\hline $\mathrm{R} 2$ & 23 & $<$ L. $D^{\mathrm{a}}$ & 0.19 & 0.06 & 0.31 & 0.06 & $2(1)$ & 118 & 7 & 7.0 \\
\hline R3 & 68 & $<L . D$ & 0.41 & 0.11 & 0.79 & 0.10 & $4(2)$ & 84 & 10 & 7.2 \\
\hline $\mathrm{R} 4$ & 247 & $<$ L.D & 0.29 & 0.14 & 0.60 & 0.31 & $4(2)$ & 169 & 11 & 7.3 \\
\hline R5 & 208 & $<$ L.D & 0.53 & 0.06 & 1.02 & 0.11 & $2(1)$ & 20 & 29 & 7.9 \\
\hline
\end{tabular}

South bay

\begin{tabular}{ccccccccccc} 
B1 & 60 & LL.D & 0.44 & 0.07 & 0.90 & 0.10 & $2(1)$ & 29.4 & 69 & 7.9 \\
BE2 & 629 & <L.D & 0.62 & 0.06 & 1.31 & 0.10 & $6(3)$ & 16.9 & 68 & 8.0 \\
BE3 & 82 & LL.D & 0.52 & 0.08 & 1.12 & 0.08 & $2(1)$ & 24.8 & 68 & 8.1 \\
\hline
\end{tabular}

$* \mathrm{n}=$ total of measurements and the respective number of replicates in the brackets.

$¥$ The limit of detection for $\mathrm{Zn}$ was estimated in $20 \mu \mathrm{g} . \mathrm{L}^{-1}$. 
Table 2. Oysters and mussels data set.

\begin{tabular}{|c|c|c|c|c|c|c|}
\hline & $\mathrm{Zn}$ & $\delta^{66} \mathrm{JMC}$ & $2 \sigma$ & D68 JMC & $2 \sigma$ & $n$ \\
\hline \multicolumn{7}{|c|}{ Oyster Crassostrea Brasiliana } \\
\hline \multicolumn{7}{|c|}{ P1- Saco do Engenho } \\
\hline SI & 20824 & 0.48 & 0.06 & 1.03 & 0.06 & $2(1)$ \\
\hline SII & 21097 & 0.49 & 0.06 & 0.98 & 0.07 & $2(1)$ \\
\hline SIII & 20922 & 0.49 & 0.05 & 1.10 & 0.05 & $2(1)$ \\
\hline Average & $20947 \pm 138$ & $0.49 \pm 0.01$ & & $1.04 \pm 0.12$ & & \\
\hline \multicolumn{7}{|l|}{ P2-Gato } \\
\hline GAI & 4506 & 0.90 & 0.05 & 1.79 & 0.10 & $2(1)$ \\
\hline GAII & 5696 & 0.87 & 0.05 & 1.77 & 0.08 & $2(1)$ \\
\hline GAIII & 4953 & 0.87 & 0.06 & 1.82 & 0.07 & $2(1)$ \\
\hline Average & $5052 \pm 601$ & $0.88 \pm 0.03$ & & $1.79 \pm 0.05$ & & \\
\hline \multicolumn{7}{|c|}{ P3-Martins } \\
\hline MAI & 6182 & 0.82 & 0.05 & 1.69 & 0.05 & $2(1)$ \\
\hline MAII & 6561 & 0.81 & 0.05 & 1.73 & 0.07 & $2(1)$ \\
\hline MAIII & 7693 & 0.81 & 0.05 & 1.63 & 0.10 & $2(1)$ \\
\hline Average & $6812 \pm 786$ & $0.81 \pm 0.01$ & & $1.68 \pm 0.07$ & & \\
\hline \multicolumn{7}{|c|}{ P4- Itacurussá } \\
\hline ITI & 4454 & 0.83 & 0.07 & 1.66 & 0.08 & $2(1)$ \\
\hline ITII & 7625 & 0.87 & 0.05 & 1.70 & 0.06 & $2(1)$ \\
\hline ITIII & 3657 & 0.84 & 0.05 & 1.66 & 0.06 & $2(1)$ \\
\hline Average & $5245 \pm 2099$ & $0.84 \pm 0.04$ & & $1.67 \pm 0.05$ & & \\
\hline \multicolumn{7}{|c|}{ P5- Jaguanum } \\
\hline Jl & 2836 & 0.84 & 0.06 & 1.72 & 0.07 & $2(1)$ \\
\hline JII & 2941 & 0.85 & 0.07 & 1.78 & 0.08 & $2(1)$ \\
\hline JIII & 3945 & 0.84 & 0.07 & 1.72 & 0.07 & $2(1)$ \\
\hline Average & $3241 \pm 613$ & $0.85 \pm 0.01$ & & $1.74 \pm 0.07$ & & \\
\hline \multicolumn{7}{|c|}{ Mussels Perna Perna } \\
\hline \multicolumn{7}{|c|}{ P5- Jaguanum } \\
\hline W1 & 107 & 0.81 & 0.05 & 1.57 & 0.07 & $2(1)$ \\
\hline W2 & 105 & 0.82 & 0.07 & 1.47 & 0.13 & $4(2)$ \\
\hline W3 & 123 & 0.79 & 0.11 & 1.45 & 0.10 & $4(2)$ \\
\hline W4 & 130 & 0.83 & 0.06 & 1.49 & 0.11 & $4(2)$ \\
\hline W5 & 127 & 0.98 & 0.12 & 1.94 & 0.18 & $2(1)$ \\
\hline W6 & 127 & 0.85 & 0.10 & 1.66 & 0.11 & $2(1)$ \\
\hline $\mathrm{O} 1$ & 187 & 0.82 & 0.06 & 1.44 & 0.10 & $4(2)$ \\
\hline $\mathrm{O} 2$ & 128 & 0.71 & 0.08 & 1.32 & 0.08 & $2(1)$ \\
\hline $\mathrm{O} 3$ & 141 & 0.77 & 0.07 & 1.46 & 0.07 & $2(1)$ \\
\hline $\mathrm{O} 4$ & 189 & 0.80 & 0.10 & 1.40 & 0.21 & $4(2)$ \\
\hline Average & $136 \pm 29$ & $0.82 \pm 0.14$ & & $1.52 \pm 0.35$ & & \\
\hline
\end{tabular}



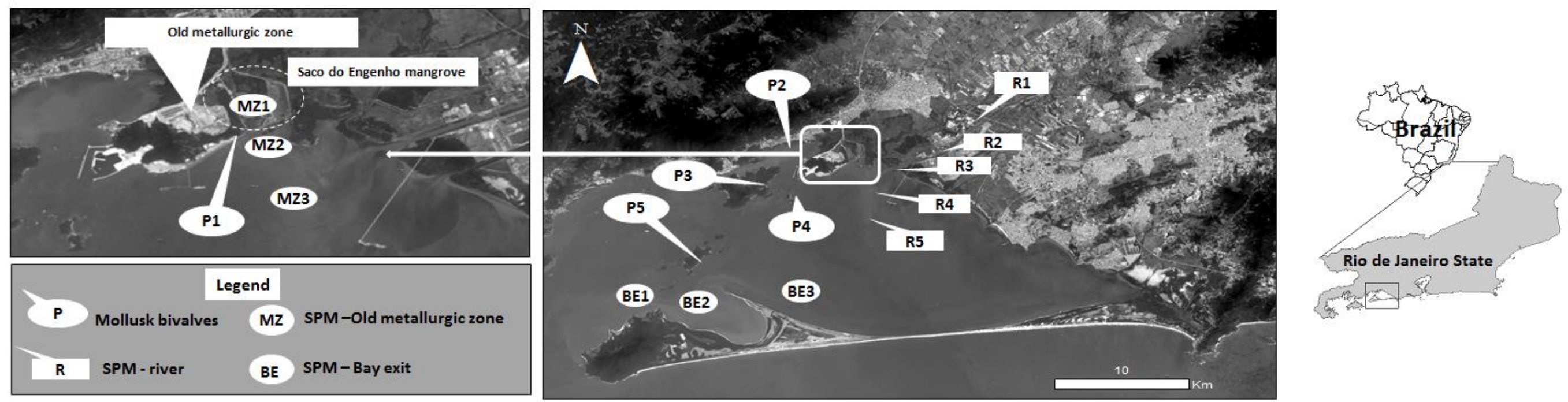

Fig.1. Map of sampling in Sepetiba bay. At left, it is shown a zoom in the old metallurgic zone, where the electroplating activity operated from 60's to end of 90's. The dashed circle line highlight the Saco do Engenho mangrove, one site heavily impacted by the wastes lixiviated from the old wastes produced by the electroplating processes. Bivalve sampling stations: P1Saco do Engenho; P2- Gato; P3-Martins; P4-Itacurussá; P5- Jaguanum. 


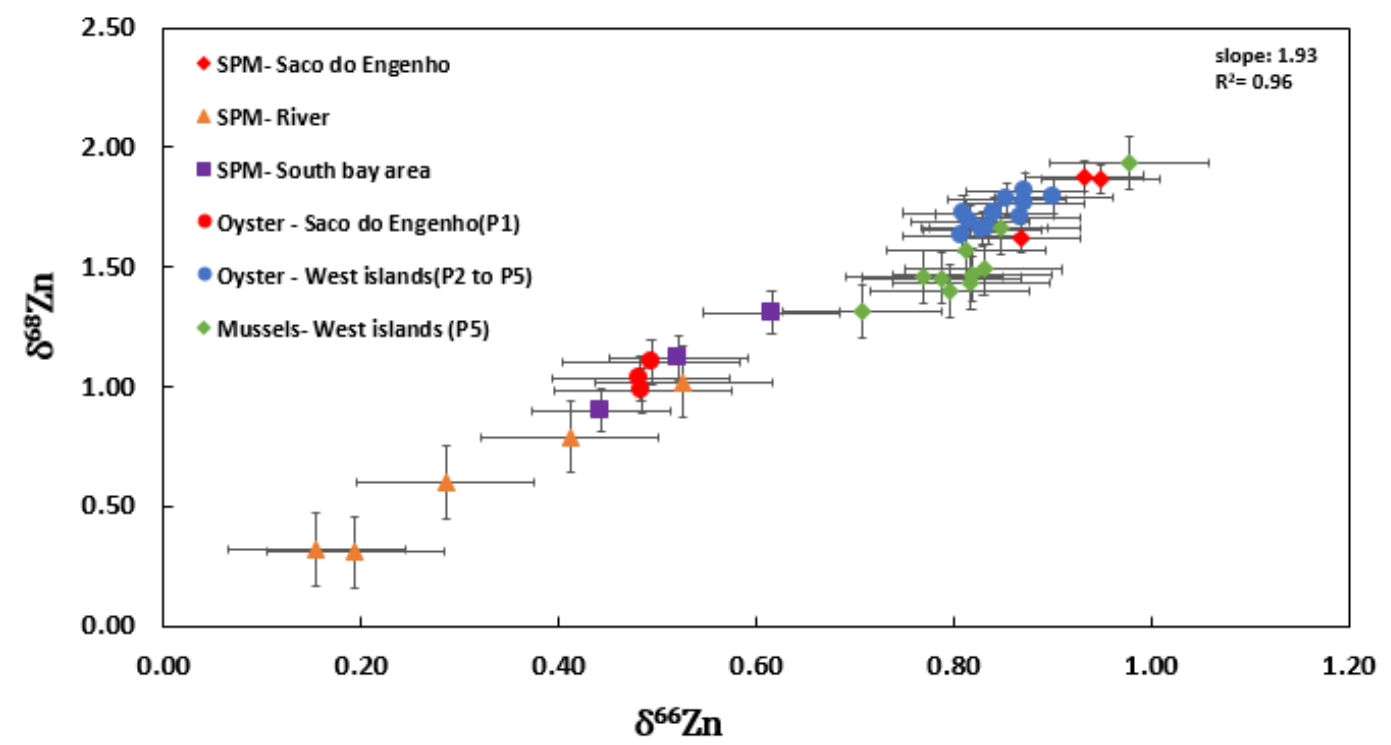

Fig.2. Zinc three-isotope plots for SPM, oyster and mussels samples follow the mass-dependent fractionation law of slope 1.93 .

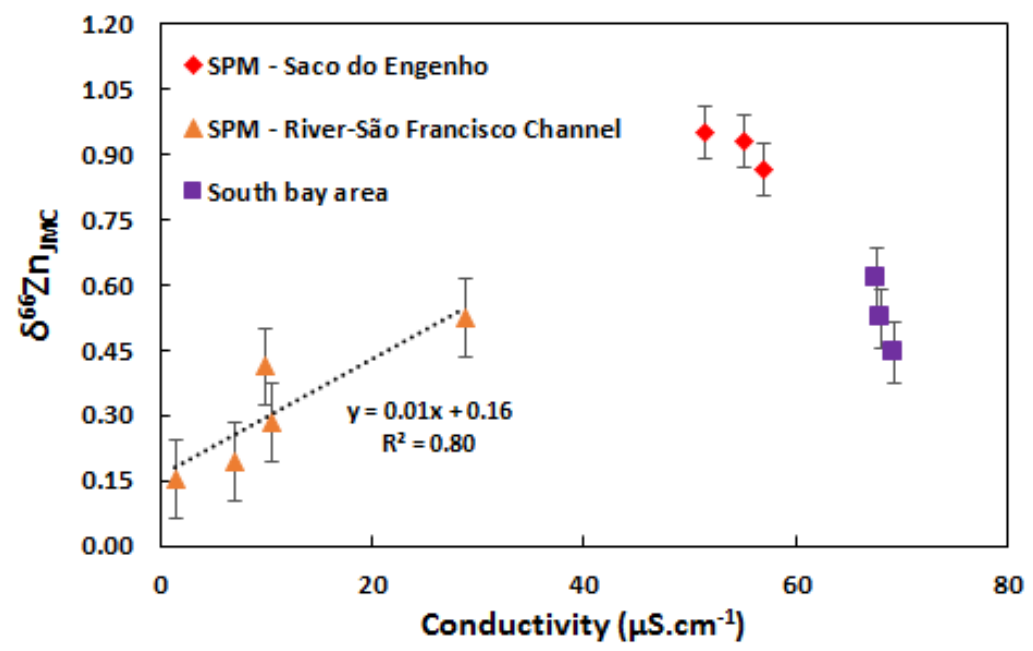

Fig.3. The $\delta^{66} \mathrm{Zn}_{\mathrm{JMC}}$ of SPM samples against conductivity. 


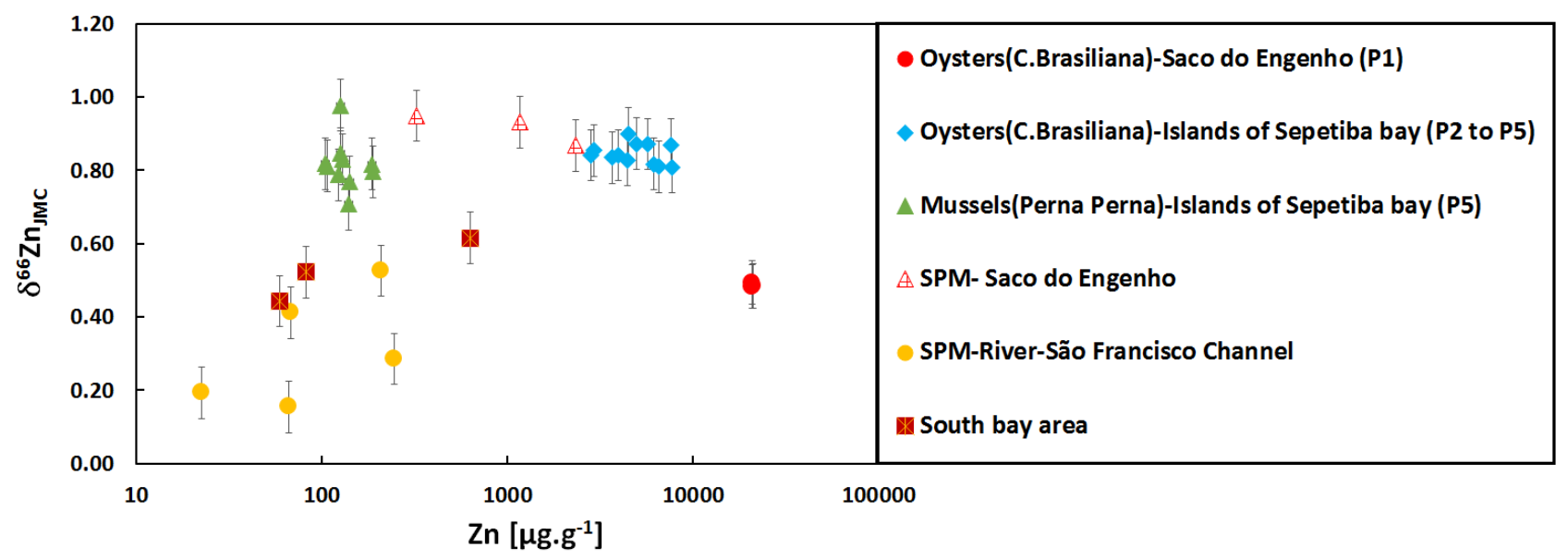

Fig.4. The $\delta^{66} \mathrm{Zn}_{\mathrm{JMC}}$ and $\mathrm{Zn}$ concentrations of SPM, oysters and mussels samples of Sepetiba bay. The error bars $(2 \sigma)$ correspond to $0.07 \%$. Together are presented $\delta^{66} \mathrm{Zn}_{\mathrm{JMC}}$ values of bivalves mollusks reported in previous studies in their respective errors $(2 \sigma)$ reported

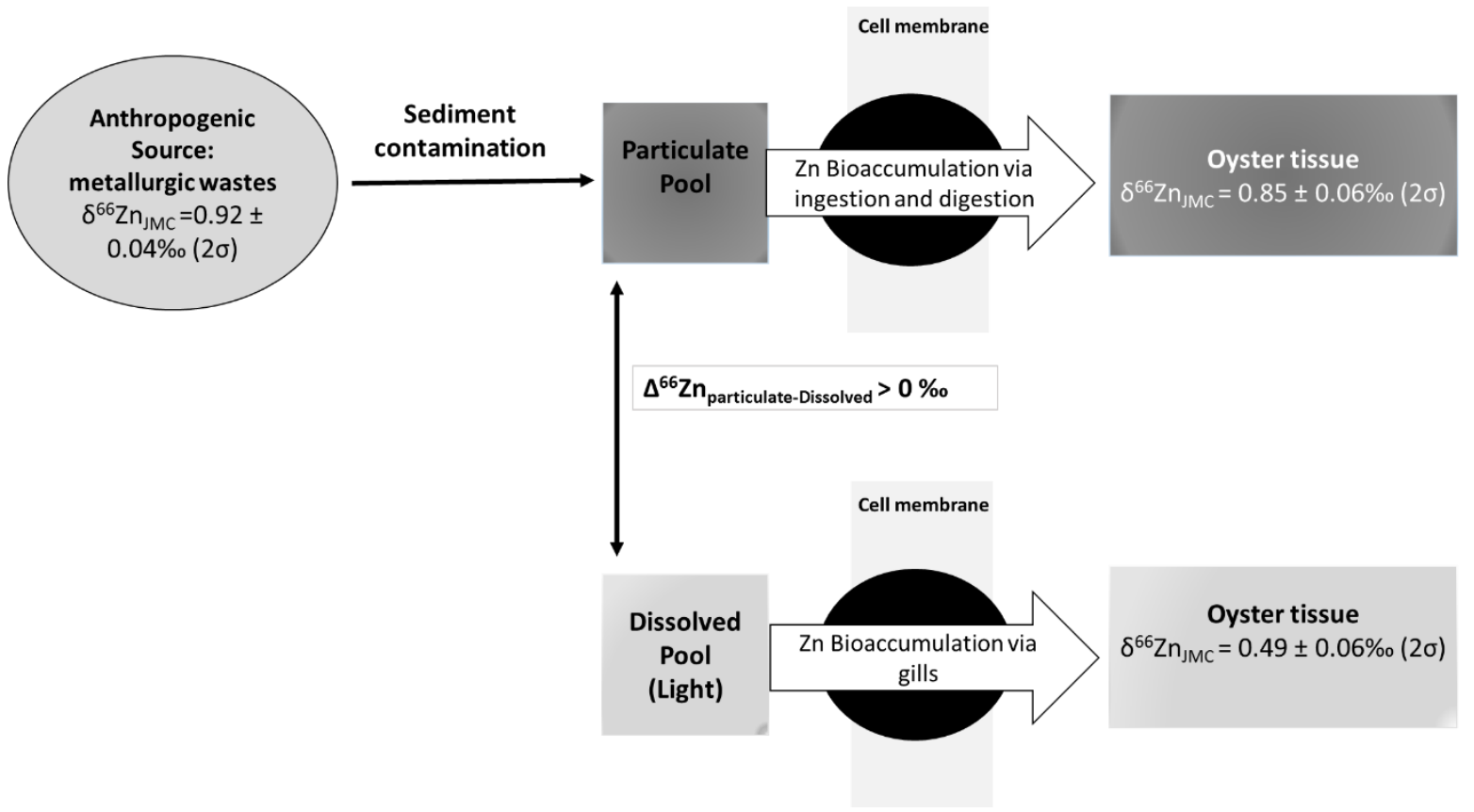

Fig.5. Model of $\mathrm{Zn}$ isotope fractionation for bivalve mollusks of Sepetiba bay. The $\delta^{66} \mathrm{Zn}_{\mathrm{JMC}}$ values of can be explained by two different routes of $\mathrm{Zn}$ bioaccumulation: one via dissolved phase and other via particulate phase, with preferential incorporation of the labile $\mathrm{Zn}$ bound-particles. Light refers to enrichment of light isotopes in the dissolved phase promoted by sorption processes at interfaces of solid surfaces, as demonstrated and predicted in experimental and theoretical studies (Bryan et al., 2015; Szynkiewicz and Borrok, 2016). 


\section{Chapter 7}

\section{MAIN FINDINGS AND CONCLUSIONS}

This thesis investigated the applicability of $\mathrm{Zn}$ isotopes as a tracer system for the sources and biogeochemical processes of this metal, and as a potential biomonitoring tool for metal contamination in coastal-zone ecosystems. The first step of this work addressed to establish a method for chromatographic separation and determination of $\mathrm{Zn}$ isotopic compositions in environmental reference materials. An ion exchange chromatography protocol was adjusted to enable faster sample throughput and the instrumental mass bias processes in MC-ICP-MS instruments was investigated. The improved chromatographic protocol yielded precise and quantitative recoveries $(99 \pm 7 \%, \sigma, \mathrm{n}=16)$, while the mass bias correction using $\mathrm{Cu}$ as external dopant provided precisions better than $0.02 \%$ ( $2 \sigma$, $n=7)$. Analysis of reference materials of silicate rocks BHVO-2 basalt; BCR-2 basalt; AGV-2 andesite) agreed with previous studies, while the $\mathrm{Zn}$ isotopic dataset for three environmental reference materials (San Joaquin Soil SRM 2709- $\delta^{66 / 64} \mathrm{Zn}_{\mathrm{JMC}}=+0.28$ $\pm 0.10 \%$; 1646a Estuarine Sediment- $\delta^{66 / 64} \mathrm{Zn}_{\mathrm{JMC}}=+0.32 \pm 0.06 \%$; 1573 a tomato leaves $\delta^{66 / 64} \mathrm{Zn}_{\mathrm{JMC}}=+0.79 \pm 0.09 \%$ ) contributed to fill a gap in the metrological traceability and analytical control of $\mathrm{Zn}$ isotopic data for environmental matrices.

Then, $\mathrm{Zn}$ isotopes were determined in natural samples collected from Sepetiba bay (southeastern Brazil) and ores from Vazant deposit (Brazil). The $\mathrm{Zn}$ isotope compositions of the samples (expressed using the $\delta^{66 / 64} \mathrm{Zn}$ notation relative to the JMC 30749-L solution) varied between -0.01 and $+1.15 \%$, including rocks, sediment cores, leaves of mangrove's trees, tissues of bivalve mollusks (oysters and mussels) and ores.

Sediment and rock samples enabled the identification of three main end-members: i) continental materials brought via rivers; ii) marine sources and iii) a major anthropogenic source associated to the old electroplating wastes released into the bay. The $\delta^{66 / 64} \mathrm{Zn}_{\mathrm{JMC}}$ signature for metallurgical wastes was estimated to $+0.86 \pm 0.15 \%$ o $(2 \sigma)$, which is heavier than the values observed for willemite (ranging from -0.1 to $+0.14 \%$ ). This suggests a significant fractionation induced by electroplating processes. The $\delta^{66 / 64} \mathrm{Zn}_{\text {JMC }}$ signature for the terrestrial natural material background end member was $+0.28 \pm 0.12 \%$ o $(2 \sigma)$, while the oceanic material that enters the bay was characterized by $\delta^{66} \mathrm{Zn}_{\mathrm{JMC}}$ values of $+0.45 \pm 0.03 \%$ o $(2 \sigma)$. 
Sediment cores collected in the mud flat showed high correlation between $\delta^{66 / 64} \mathrm{Zn}$ and $\mathrm{Zn}$ enrichment factors, suggesting (i) good preservation of isotopic records of natural and anthropogenic sources and (ii) no significant isotopic fractionation during sediment transport or by diagenetic reactions post deposition in the estuarine system. The sediment core sampled from a mangrove located in the zone impacted by the metallurgy presented levels of $\mathrm{Zn}$ up to $4 \%$ and preserved the isotopic signatures of electroplating wastes. However, there is evidence that biogeochemical processes triggered by hydrodynamics, bioturbation and rhizosphere processes slightly changed the isotopic signatures in some layers from this core toward heavier $\delta^{66 / 64} \mathrm{Zn}_{\text {JMC }}$ values above 1.0\%o. Spatial and temporal analysis of sediments fit well in a model of mixing involving terrestrial, marine and the anthropogenic end-members (i.e., metallurgical waste). Calculations based in this mixing model quantified the contribution of this major anthropogenic source of $\mathrm{Zn}$ as ranging from negligible values in the pre-industrial period to nearly $80 \%$ during periods of electroplating activities. The sedimentary records of this anthropogenic contribution consistently decreased in different areas of the bay during the most recent years, reflecting the end of metallurgical activities in 1998. Overall, these findings demonstrates that $\mathrm{Zn}$ isotope determinations of sediments are effective to trace anthropogenic sources both spatially and temporally in coastal areas and mangrove forests.

The $\mathrm{Zn}$ isotope systematics of bivalve tissues discriminated two groups: one comprising bivalve samples collected in the old metallurgic zone $\left(\delta^{66 / 64} \mathrm{Zn}_{\mathrm{JMC}}+0.49 \pm\right.$ $0.06 \%, 2 \sigma, n=3)$ and other composed by the rest of sampling stations $(+0.83 \pm 0.10 \%$, $2 \sigma, n=22)$. Unlike sediments, bivalves did not enable the identification of end-member or tendencies of mixing process, suggesting limitations to sources tracing. Instead, these bioisotopic signature can be related to mechanism of bioaccumulation, i.e. uptake via dissolved and particulate phase. It is hypothesized that in the zone heavily impacted zone by old electroplating wastes, the bivalves incorporate the high levels of $\mathrm{Zn}$ in the dissolved phase though the bivalve gills by facilitated diffusion or actively pumped across the membranes. Outside this zone, due the low content of $\mathrm{Zn}$ in the dissolved phase and high $\mathrm{Zn}$ concentrations on suspended particulate matter, bivalves incorporate the labile $\mathrm{Zn}$ bound to particulate matter during the gut digestion.

Zinc isotopic signatures of leaves ranged between +0.07 and $+0.25 \%$ and were also not able to identification of sources due to the significant $\mathrm{Zn}$ isotopic fractionation during $\mathrm{Zn}$ upktaking. However, analysis of the $\mathrm{Zn}$ isotopic fractionation between mangrove leaves and sediments (expressed using $\Delta^{66} \mathrm{Zn}_{\text {plant-sediment }}$ ) varied between -0.73 
to $-0.25 \%$ and was negatively correlated to the $\mathrm{Zn}$ sediment concentrations, suggesting that high $\mathrm{Zn}$ contaminated sites trigger tolerance mechanisms of mangrove's trees, inducing different $\mathrm{Zn}$ isotopic pattern from leaves collected in sites with low contamination.

The $\mathrm{Zn}$ isotope compositions of biological samples analyzed in this study indicate limitations to tracer sources, but great potential to elucidate routes of metal bioaccumulation in bivalve molluscs and to unveil physiological processes and responses of plants during environmental stress. Future studies are required to link the $\mathrm{Zn}$ speciation, bioavailability and mechanisms of isotopic fractionation during its incorporation to the biota. This knowledge can be useful to apply $\mathrm{Zn}$ isotopes as auxiliary tool in the setting of water and sediment quality criteria and to provide new insights on metal transference to food chains of coastal ecosystems.

To conclude, $\mathrm{Zn}$ isotopes compositions of abiotic samples such as sediments are effective to detect biogeochemical changes triggered by anthropogenic activities and to support prevention, monitoring and prediction of risks in coastal sites impacted by metal contamination. Biological samples of bivalves and leaves of mangrove's trees are not suitable to sources tracing, but the distinct isotopic patterns of $\mathrm{Zn}$ found for those samples from sites highly contaminated are promising to apply $\mathrm{Zn}$ isotopes as biomarkers of metabolic pathways and physiological effects associated to metal contamination. However, more investigations are required to elucidate the controlling mechanisms of $\mathrm{Zn}$ bioisotopic signatures. 


\title{
RESUMO ESTENDIDO EM PORTUGUÊS
}

\author{
(Referências estão inseridas nos respectivos capítulos do corpo principal da tese)
}

\section{Capítulo 1- Contexto, objetivos e área de estudo}

Nas últimas décadas, avanços conceituais de química e física e o desenvolvimento tecnológico na instrumentação da espectrometria de massa, permitiram a medição de isótopos radioativos e estáveis com alta precisão e sensibilidade (Baskaran, 2011). Desde então, análises isotópicas de materiais biológicos e abióticos vem fornecendo informações tanto qualitativas como quantitativas sobre processos químicos, físicos, geológicos e biológicos que governam os ciclos naturais dos elementos químicos. Este novo campo científico, baseado em medições isotópicas e conhecimentos multidisciplinares, deu-se o nome de Biogeoquímica Isotópica (Baskaran, 2011).

As diferentes esferas de nosso planeta -biosfera, hidrosfera, atmosfera, geosfera- estão sob constantes transformações devido às mudanças climáticas e pelas perturbações dos ciclos elementares naturais pelas atividades antrópicas (Biachi, 2007; Mason, 2001). Logo, a aplicação de isótopos nos sistemas naturais apresenta importante papel na elucidação destas mudanças com a criação de modelos que possam descrever e predizer suas causas e consequências.

De especial interesse para estudos ambientais e de relevância para a saúde humana estão os sistemas isotópicos estáveis de metais transição e pós-transição (e.g, Zn, Cu, Fe, Mo). Estes elementos são ubíquos na natureza e normalmente ocorrem como elementos traços, à exceção do Fe (Adriano \& Adriano, 2001). Apresentam-se como importantes micronutrientes para os seres vivos e tem grande importância econômica e tecnológica na indústria, mineração e metalurgia, bem como sérias implicações ambientais decorrentes destas atividades antrópicas (Kossof et al., 2014; Ettler et al., 2016). Os ciclos naturais destes metais são drasticamente alterados devido à grande remobilização de reservatórios profundos para a superfície terrestre, o que leva à contaminação e enriquecimento destes elementos nos compartimentos naturais como solo, água e ar (Mason, 2001). Dependendo da biodisponibilidade e especiação, metais traços podem ser incorporados pela biota, incluindo o Homem. Alguns deles, como Zn, $\mathrm{Cu}$ e Mo, possuem papel biológico importante como 
componentes de enzimas e proteínas (metaloproteínas) e também como participantes diretos de reações bioquímicas à nível celular (Reylly. 2004). Entretanto, em altas concentrações, metais traços podem apresentar alta toxicidade, fornecendo riscos aos organismos vivos. Outros metais, que não desempenham funções biológicas, como $\mathrm{Hg}$ e $\mathrm{Cd}$, mesmo em pequenas quantidades podem causar sérios danos à biota e aos humanos (Adriano \& Adriano, 2001; Sparks, 2005).

Isótopos estáveis de transição e pós-transição são fracionados na natureza ou artificialmente durante reações biogeoquímicas, resultando em produtos ou reservatórios isotopicamente distintos do substrato ou reagente original (Wiederhold, 2015). A compreensão dos principais fatores de fracionamento isotópico, suas magnitudes e mecanismos, isto é, em equilíbrio ou via cinética, abre possibilidades para usar as razões isotópicas de metais de transição como traçadores para obtenção de informações sobre fontes, transporte e destino destes elementos no ambiente (Wiederhold. 2015).

Dentre estes novos sistemas isotópicos, isótopos de Zn tem sido aplicado com sucesso na discriminação de fontes naturais e antrópicas, em contextos de contaminação urbana por tráfico veicular (Gioia et al., 2008; Thapalia et al., 2015), efluentes domésticos e esgoto (Chen et al., 2008ç, 2009), mineração e metalurgia (Dogolopova et al., 2006; Mattielli et al., 2006; Weiss et al., 2007; Sivry et al., 2008). A eficácia destes isótopos decorre do significante fracionamento isotópico que estes apresentam em processos industriais, como metalurgia, eletrólise e combustão à altas temperaturas, resultando em subprodutos e manufaturados isotopicamente distintos da matéria prima inicial (Kavner et al.; 2008; Sivry et al., 2008; Borrok et al.; 2010; Ochoa and Weiss, 2015; Thapalia et al., 2015; Yin et al.; 2015). Além disso, isótopos de Zn também são fracionados por processos de superfície à baixa temperatura, tais como adsorção em superfície de sólidos orgânicos e inorgânicos, complexação por ligantes, precipitação, incorporação biológica, transporte intercelular, etc. (Pichat et al., 2003; Stenberg et al., 2004; Weiss et al., 2004; Pokrovsky et al., 2005; Bermin et al., 2006; Gélabert et al., 2006; Balistrieri et al., 2008; Peel et al., 2009; Fujii et al.,2011; Jouvin et al., 2012; Little et al., 2014b; Kafantaris and Borrok, 2014; Matthies et al., 2014; Dekov et al., 2014; Coutaud et al., 2014; Zhao et al., 2014; Bryan et al., 2015; Veeramani et al., 2015). 
Apesar de uma considerável literatura, desenvolvida em pouco menos de duas décadas, apontar por enorme potencial dos isótopos de $\mathrm{Zn}$ como traçador de fontes e processos, a aplicabilidade deste sistema isotópico em ambientes costeiros permanece pouco investigada. A zona de transição entre o ambiente terrestre e marinho é caracterizada por expressivos gradientes físico-químicos nas propriedades da água e do sedimento, como $\mathrm{pH}$, salinidade, condições redox, matéria orgânica, além de intensa diagênese promovida pela atividade microbiana e múltiplas fontes naturais e antrópicas. Todo este conjunto de processos e fontes tornam o estudo dos ciclos biogeoquímicos de metais em sistemas costeiros extremamente desafiador, uma vez que solubilidade, mobilidade, biodisponibilidade e toxicidade destes elementos são constantemente modificados (Biachi, 2007; Du Laing, 2009; Mason, 2013). Aparte desta complexidade, os ambientes costeiros também apresentam grande relevância ambiental e econômico, pois neles se encontram ecossistemas essenciais, dos quais extraímos matérias-primas, combustíveis e comida, além de funcionarem como pontos estratégicos para o transporte comercial (Agardy \& Alder, 2010; Lewis, 2011; Bayen, 2012). Todas estas benesses levaram historicamente as populações humanas de todo o planeta se assentarem preferencialmente próximo da costa, e hoje, mais de $60 \%$ da população mundial se concentra numa faixa de $60 \mathrm{~km}$ dos estuários. Como consequência, estas zonas são fortemente pressionadas pela atividade antrópica, tornando-se mais suscetíveis a processos de assoreamento, eutrofização, deterioração da qualidade da água e exposição à contaminantes orgânicos e metálicos (Alcamo and Bennett, 2003). Desde que a manutenção da qualidade dos ecossistemas costeiros são fundamentais para o contínuo progresso econômico e manutenção do bem-estar social do homem, torna-se imperativo o desenvolvimento de ferramentas que sejam capazes de identificar mudanças biogeoquímicas de sistemas naturais de forma a auxiliar à prevenção, monitoramento, predição de riscos e à remediação de áreas impactadas (Biachi, 2007). Neste sentindo, as composições isotópicas de Zn de amostras naturais -sedimento, água, planta, animais biomonitores como bivalves- constituem uma promissora ferramenta para estudos ambientais de ambientes costeiros.

Assim, o principal objetivo desta tese foi investigar a aplicabilidade de isótopos de Zn como traçadores de fontes e processos biogeoquímicos, e também como ferramenta de biomonitoramento de ecossistemas costeiros. Como área modelo, foi escolhida a baía de Sepetiba, um estuário do tipo lagunar, localizada a $60 \mathrm{~km}$ da cidade do Rio de Janeiro. A escolha 
desta baía se justifica - além da presença de importantes ecossistemas como estuários, mangues, planícies de maré- por seu histórico de contaminação pela atividade de refino de $\mathrm{Zn}$ (galvanoplastia), que perdurou entre a décadas de 60 a 90 (Molisani et al., 2004; Rodrigues et al., 2012). Estudos biogeoquímicos prévios nas últimas décadas consolidaram uma considerável base de dados e conhecimentos acerca da dinâmica dos contaminantes metálicos nessa baía, os quais servem de ponto de partida para a amostragem e interpretação de resultados neste trabalho (Molisani et al., 2004; Lacerda and Molisani, 2006). Atualmente, a baía de Sepetiba hospeda em sua bacia de drenagem uma população estimada em mais 1,400.000 habitantes, o maior complexo industrial siderúrgico da América Latina e três grandes portos (Molisani et al., 2006; Roncarati and Carelli, 2012). Os principais rios na baía são o Rio Guandu, Guarda e Guandu-Mirim, os quais desembocam por meio de canais artificiais. Dentre eles, o canal do São Francisco, responde por mais de 86\% de todo aporte de água doce no sistema lagunar (Molisani et al., 2004).

Para conduzir este projeto na baía de Sepetiba, estabeleceu-se primeiro uma metodologia analítica para determinação de composições isotópicas de Zn em amostras naturais. A partir dos dados obtidos das amostras desta área de estudo, objetivou-se:

i) Identificar fontes e destinos do $\mathrm{Zn}$ antropogênico;

ii) Reconstruir temporalmente e espacialmente a evolução da contaminação de Zn;

iii) Verificar a influência de processos biogeoquímicos estuarinos nas assinaturas isotópicas de Zn durante o transporte e deposição deste elemento;

iv) Compreender os efeitos da contaminação antrópica nos mecanismos de incorporação de $Z n$ e processos de tolerância pela vegetação de mangue;

v) Elucidar o significado do registro isotópico do tecido mole de moluscos bivalves em termos de fontes ou processos. 


\section{Capítulo 2- Biogeoquímica de metais-traços em ambientes costeiros e de mangue}

Em ambientes costeiros, diversas feições podem ser encontradas, incluindo costões rochosos, bancos de areias, dunas, recife de corais, lagunas, estuários, zonas intermarés, planícies de inundação como florestas de mangues, pântanos, etc. Este capítulo trata da biogeoquímica de metais traços de estuários e zonas intermarés devido à relevância ecológica relacionada à contaminação antrópica nesses ambientes e seu potencial risco para à biota e à saúde humana (Jickells \& Rae, 1997; Alcamo \& Bennett, 2003).

Estuários correspondem a principal via de transporte dos materiais continentais para o oceano. Eles podem ser definidos como um corpo aquático, semi-fechado, que se estende até o limite da influência de maré, no qual a água do mar entra a partir de uma ou mais conecções com o oceano aberto, ou ainda, um corpo de água costeiro salino diluído pela água doce (Perillo, 1995)

Metais-traços chegam aos estuários por processo naturais, como intemperismo e erosão das rochas e dos solos, atividade vulcânica, ou lançados por fontes antrópicas, como atividades industriais, agrícolas e domésticas presentes na bacia de drenagem (Adriano \& Adriano, 2001; Sparks, 2005). Eles atingem o sistema estuarino através da atmosfera, águas subterrâneas ou através de vias fluviais, estes últimos constituindo o principal aporte (Mason, 2013). Ao longo do percurso no sistema fluvio-estuarino, metais-traços são transformados por processos biogeoquímicos e distribuídos entre as fases particulada $(0.45 \mathrm{~mm})$, coloidal ( $1 \mathrm{~nm}-0.45$ milímetros $)$ e dissolvida $(<1$ $\mathrm{nm}$ ). No geral, as contribuições antropogênicas e formação de complexos estáveis com matéria orgânica dissolvida tendem a aumentar as concentrações de metais na fase dissolvida (Windom \& Smith, 1985; Tercier-Waeber \& Taillefert, 2008; Mason, 2013). Por se associarem fortemente a fase particulada, sua distribuição entre as fases sólida e dissolvida é influenciada pela carga de material particulado suspenso (Tuner \& Millward, 2002; Mason, 2013).

Metais-traço ocorrem na fase dissolvida em três formas principais: como íon livre, complexo inorgânico e orgânico. Os cinco ligantes inorgânicos de importância primordial em águas naturais são $\mathrm{F}^{-}, \mathrm{Cl}^{-}, \mathrm{SO}_{4}{ }^{2-}, \mathrm{OH}^{-}, \mathrm{HCO}^{3-}, \mathrm{CO}_{3}{ }^{2-}, \mathrm{HPO}_{3}{ }^{2-}, \mathrm{NH}_{3} \mathrm{e}$, em águas anóxicas, $\mathrm{HS}^{-}$e $\mathrm{S}^{2-}$ (Parametrix, 1995). Ligantes orgânicos incluem a matéria orgânica natural, constituída por 
substâncias húmicas (matéria orgânica em decomposição), que apresentam grupos funcionais orgânicos (carboxílico, aminoácidos, sulfídricos e fenólicos) como sítios de ligação (Paquin et al.2002). A formação de complexos em águas naturais influencia as taxas de processos redox, solubilidade mineral e disponibilidade bioquímica. Os íons livres são reconhecidos como a forma mais biodisponível e tóxica, enquanto complexos inorgânicos e orgânicos podem também ser potencialmente biodisponíveis e apresentarem alguma toxicidade (Anderson et al, 1984; Milero, 2001).

Nos estuários, ao longo da zona de mistura de águas doces e marinhas no estuário, o pH aumenta de valores tipicamente neutros para valores alcalinos acima de 8 , levando a desprotonação dos grupos funcionais e o aumento da capacidade de sorção das superfícies de ligação (Eby, 2004). Por sua vez, o aumento de salinidade (ou da força iônica) conduz à liberação de metais adsorvidos na superfície de coloides e partículas, devido a competição entre íons metálicos e íons maiores da água do mar pelos sítios de sorção destas superfícies, ou devido à formação de complexos de cloreto solúveis (Du Laing et al., 2009). A salinidade também favorece a coagulação e floculação de material em suspensão através da neutralização das cargas negativas do material particulado por eletrólitos presentes na água do mar (Turner \& Millward, 2000). O material floculado tende decantar no sedimento de fundo, e promove assim, a limpeza de coluna de água através da adsorção dos metais dissolvidos na superfície das partículas. (Mason, 2013). Esta característica dos estuários, torna seus sedimentos os principais sumidouros de metais exportados do continente em direção aos oceanos (Bianchi, 2007; Mason, 2013). O sedimento de fundo estuarino e das zonas intermarés também acumulam grande quantidade material orgânico, cuja decomposição catalisada por micro-organismos promove reações biogeoquímicas e gradientes redox, que levam à formação de novas fases minerais e alterações na composição das águas, bem como a especiação, mobilidade e toxicidade de metais traços (Berner, 1980; Chester, 2000). A este conjunto de processos, dá-se o nome de Diagênese.

A complexidade dos vários processos que ocorrem na interface sedimento-água, associadas ainda a dificuldades analíticas para a especiação de metais traços, inviabilizam muitas vezes a avaliação da biodisponibilidade e a toxicidade da contaminação a partir de amostras de sedimento ou água. Alternativamente, a amostragem e análise de amostras biológicas (biomonitores), tais como os tecidos de organismo ou seus fluidos, podem informar sobre as quantidades de metais que 
incorporados nos organismos, indicando a carga total de metais no ambiente que apresenta relevância ecotoxicológica (Raibow, 1995;. Mercado et al., 2003). Assim, biomonitores são úteis para o estabelecimento de variações, espaciais e/ou temporais, na biodisponibilidade de metais e são vantajosos para reduzir os custos dos programas de monitoramento ambiental (Raibow, 1995).

Moluscos bivalves é a classe de animais mais utilizados em estudos ambientais de biomonitoramento de contaminação por metais (Oehlmann e Schulte-Oehlmann, 2003). Os bivalves representam a segunda classe mais abundante entre as seis classes do filo Mollusca, um dos mais diversificados no reino animal (mais de 130,000 espécies conhecidas; Gosling, 2003). Eles são animais de corpo mole comprimidos lateralmente por duas conchas de proteção. Abundantes e com ampla ocorrência geográfica, eles ocorrem em quase todos os habitats costeiros encontrados na Terra em uma grande variedade de substratos, incluindo costões rochosos, recifes de coral, zonas intermarés, e praias arenosas, e apresentam um papel ecológico vital para os ecossistemas aquáticos e terrestres (Gosling, 2003).

Vários atributos fazem os moluscos organismos ideais para monitoramento de contaminação por metais: em primeiro lugar, sua natureza sedentária não requer a consideração de fatores migratórios complexos na interpretação dos dados de bioacumulação de metais (Gupta e Singh, 2011; Zhou et al., 2008). Em segundo lugar, eles apresentam altas concentrações de metais devido suas altas taxas de bioacumulação que facilitam aspectos de análise laboratorial (Gupta e Singh, 2011; Wang et al., 1996). Outras características vantajosas incluem: tolerância a alterações ambientais e a contaminantes, apresentam populações amplas e estáveis, ciclos de vida razoavelmente longos e tamanhos de fácil manuseio (Oehlmann e Schulte-Oehlmann de 2003).

Os bivalves são capazes de incorporar metais em diferentes formas, seja como íons livres, complexados e/ou associados ao material particulado. A incorporação pode se dar pelo trato intestinal ou pelas brânquias. Metais dissolvidos são incorporados pelas brânquias. Metais ligados a fases de partículas podem ser incorporados pós-desorção ou solubilização por enzimas durante os processos de digestão no trato gastrointestinal (Griscom e Fishcer, 2004). Após atravessarem a membrana plasmática, metais essenciais se ligam em sítios específicos dentro da célula onde desempenham um papel essencial, por exemplo, zinco na enzima anidrase carbônica ou cobre em hemocianina. Caso, estejam em excesso, podem agir em sítios de outros elementos, e assim, causar 
efeitos adversos. Para evitar intoxicação, as células de bivalves podem ativar mecanismos de desintoxicação. Estes envolvem a ligação de metais a proteínas, tais como metalotioneínas ou a grânulos insolúveis, a fim de tornar o metal indisponível quimicamente para participar dos

processos metabólicos (Raibow, 2002; Raibow, 2007). No geral, metais-traços causam efeitos tóxicos quando a taxa de absorção de metal excede as doses taxas de desintoxicação e excreção do metal (Rainbow, 2002; Ahlf et al., 2009).

\section{Capítulo 3- Biogeoquímica dos isótopos estáveis de Zn: uma revisão}

Zinco (Zn) é um metal de pós-transição, calcófilo do Grupo 12, ubíquo no ambiente e com participação em muitos processos biogeoquímicos, tanto intra e intercelular, e em sistemas abióticos, que abrangem desde o núcleo até a superfície terrestre, bem como em materiais extraterrestres. $\mathrm{O} \mathrm{Zn}$ desempenha funções vitais para os seres vivos como componente estrutural de várias proteínas metabolicamente importantes (Cloquet et al, 2006; Hansch e Mendel, 2009). Num adulto humano, cerca de 2 g de Zn são distribuídos por todo o corpo, compondo enzimas essenciais, como anidrase carbônica e carboxipeptidase A (Cloquet et al., 2006). Este elemento é encontrado na natureza principalmente combinado com enxofre e oxigênio, sob a forma de sulfetos ou óxido, respectivamente. Os principais minérios de Zn são a esfarelita e wurtzita, ambas com a fórmula $\mathrm{ZnS}$, mas com estruturas cristalográficas distintas (cúbica e hexagonal). A maior parte da Zn produzido ( 95\%) no mundo vem de minérios de sulfetos de $\mathrm{Zn}$ e maior parte de seu uso é empregado na galvanoplastia (http://www.zinc.org).

Atividades antrópicas têm alterado o ciclo natural do $\mathrm{Zn}$, ocasionando seu enriquecimento no solo, ar, água e sedimento. As principais fontes antrópicas de Zn são as emissões veiculares, efluentes de águas residuárias e esgoto, e rejeitos industriais, metalúrgicos e de mineração, (John et al, 2007; Weiss et al.2007; Chen et al.2009; Juillot et al, 2011; Yin et al, 2015). Os aportes de Zn para a atmosfera aumentaram em $25 \%$ devido às atividades antrópicas e estes impactos tem se refletido sobre a química da água da chuva de grandes cidades e até mesmo em regiões distantes 
dos centros industriais (Gaillardet et al, 2003; Mason, 2013). Além dessas emissões relacionadas com a atividade humana, a ciclagem natural do $\mathrm{Zn}$ no ambiente continua ininterruptamente movida pelo intemperismo e erosão das rochas e dos solos (Kabata-Pendias, 2008; Adriano e Adriano, 2001). Todos estes processos mobilizam uma variedade de compostos de $\mathrm{Zn}$ no ambiente.

Nos últimos 20 anos, os avanços na instrumentação da espectrometria de massa permitiram medir com grande precisão as composições isotópicas de $\mathrm{Zn}$. A compreensão dos fatores que controlam a abundância relativa de seus isótopos na natureza se deve em grande parte a sólida base teórica herdada dos isótopos estáveis clássicos não-metálicos $(\mathrm{C}, \mathrm{N}, \mathrm{H}, \mathrm{O}, \mathrm{N})$, desenvolvidos nas décadas anteriores. Similarmente aos isótopos não-metálicos, o fracionamento isotópico de $\mathrm{Zn}$ decorre dos efeitos da mecânica quântica associados a diferenças nos níveis de energia de frequência vibracional de ligações entre os isótopos e ligantes adjacentes (McSween et al., 2003). Portanto, processos químicos, físicos e biológicos (por exemplo, evaporação, fusão, cristalização, difusão, complexação, adsorção, precipitação, transporte intercelular, etc.) podem afetar a abundância relativa de seus isótopos entre reagentes e produtos em reações físico-químicas ou entre as diferentes fases componentes de um sistema (Hoefs, 2009).

O fracionamento isotópico de $\mathrm{Zn}$ é dependente da massa dos isótopos e ocorre por dois mecanismos: cinético e equilíbrio. O primeiro ocorre nas reações irreversíveis e unidirecionais, como a evaporação, reações de dissociação, reações mediadas biologicamente, e difusão. $\mathrm{O}$ fracionamento cinético favorece a formação de produtos enriquecidos no isótopo leve porque suas ligações são quebradas mais rapidamente que ligações que envolvem o isótopo pesado (Weiss et al, 2007; McSween et al., 2003). O fracionamento em equilíbrio isotópico envolve a redistribuição de isótopos de um elemento entre as várias espécies ou compostos durante uma reação de equilíbrio químico ou físico, onde os isótopos pesados são enriquecidos nos compostos termodinamicamente mais estáveis ou com a ligações mais fortes (Wiederhold, 2015). Como regra geral, o enriquecimento do isótopo pesado é esperado em compostos que apresentam maior grau de oxidação (íons de alta carga tendem a formar ligações mais estáveis), baixa configuração eletrônica de spin e menor número de coordenação (Anbar e Rouxel, 2007). No estado de equilíbrio, as taxas das reações para a frente e para trás são idênticas e a magnitude do fracionamento tende a diminuir à medida que a temperatura aumenta, na maioria dos casos proporcional a $1 / \mathrm{T}^{2}$ (Allègre, 2008; Wiederhold, 2015). As variações isotópicas de Zn são relatadas como valores relativos em 
comparação a um dado padrões de referência, utilizando valores de delta $(\delta)$ expressos em por mil, que podem assumir valores positivos ou negativos. À medida que o isótopo pesado é usado no numerador e o leve no denominador, as razões mais positivas são mais "pesadas" em comparação com o padrão, enquanto que os valores negativos são mais "leves". Para o sistema isotópico de Zn, a relação $\left({ }^{66} \mathrm{Zn} /{ }^{64} \mathrm{Zn}\right)$ é geralmente escolhida devido à grande abundância destes isótopos e são expressos como valores $\delta^{66 / 64} \mathrm{Zn}$, como segue:

$$
\delta^{66 / 64} Z n=\left(\frac{\left(\frac{{ }^{66} Z n}{{ }^{64} Z n}\right)_{\text {amostra }}}{\left(\frac{{ }^{66} Z n}{{ }^{64} Z n}\right)_{\text {padrão }}}-1\right)
$$

A notação $\delta$ também é vantajosa porque supera o problema analítico de comparar diretamente as razões medidas entre os laboratórios, o que torna difícil de se reproduzir de maneira exata e precisa (Wiederhold, 2015). O estabelecimento de um padrão de referência comum facilita comparações e calibrações interlaboratoriais. Para o sistema isotópico de $\mathrm{Zn}$, dois materiais isotópicos de referência certificados estão disponíveis comercialmente, ambos fornecidos pelo Institute for Reference Materials and Measurements (IRMM-651 and IRMM-3702) (Vogl e Pritzkow, 2012; Irrgeher, 2015). No entanto, a solução elementar Zn JMC 3-0749 L ("JMC") tem sido adotada na maioria dos trabalhos publicados na literatura relacionada, sendo também escolhida para este trabalho para expressar as composições isotópicas de $\mathrm{Zn}$.

Dada a relação inversa com a temperatura, o fracionamento isotópico de $\mathrm{Zn}$ torna-se bastante discreto em processos de diferenciação magmática, e portanto, as composições de rochas ígneas, metamórficas e sedimentares tendem a se agrupar dentro de uma faixa estreita de valores $\left(\delta^{66 / 64} \mathrm{Zn}_{\text {JMC }}=+0.20 \mathrm{a}+0.40 \%\right.$; Chapman et al.2006; Cloquet et al.2006; Herzog et al.2009; Moynier et al.2009; Chen et al.2013). Investigações em rochas vulcânicas mostraram que os processos de alta temperatura na diferenciação magmática induzem fracionamentos discretos, com valores de $\delta^{66 / 64} \mathrm{Zn}_{\text {JMC }}$ não maiores do que $+0.10 \%$. Uma vez que magma e crosta não se diferenciam isotopicamente uma composição isotópica de Zn média para a Terra tem sido estimada em $\delta^{66 / 64} \mathrm{Zn}_{\mathrm{JMC}}=+0.28 \pm 0.05 \%(2 \sigma)($ Chen et al.2013). Apesar desta restrita faixa de composições 
isotópicas, existem casos de unidades geológicas com valores $\delta^{66 / 64} \mathrm{Zn}_{\mathrm{JMC}}$ contrastantes à média da crosta (por exemplo, o orógeno de Taiwan), que habilitam a utilização de isótopos de Zn como traçador de proveniência de sedimentos (Bentahila et al., 2004).

Perfis de solos apresentam maior variedade de composições isotópicas do que a rocha, com valores de $\delta^{66 / 64} \mathrm{Zn}_{\text {JMC }}$ abrangendo de -0.18 a $+0.55 \%$ (Fekiacova et al., 2015). Esta ampla faixa de valores pode ser atribuída à combinação de processos biológicos e abióticos na redistribuição de $\mathrm{Zn}$ em diferentes horizontes do solo durante processos pedogenéticos (Viers et al.2007). Devido à complexidade inerente destes processos, padrões nas assinaturas isotópicas de Zn entre horizontes são difíceis de serem estabelecidas, apesar de uma certa tendência geral para valores de $\delta^{66 / 64} \mathrm{Zn}$ centrarem em torno $+0.1 \%$ e $+0.2 \%$ nos horizontes $\mathrm{B}$ e $\mathrm{O}$, respectivamente (Fekiacova et al., 2015). Além da pedogênese, as várias reações químicas do solo envolvendo a sorção de $\mathrm{Zn}$ em argilominerais e matéria orgânica, processos de eluição ao longo do perfil, podem alterar a especiação de Zn e, consequentemente, a sua composição isotópica. Um estudo de Zn isótopos combinada com espectroscopia de EXAFS em um sistema de sedimentos de planícies de inundação mostrou que as espécies de Zn com geometria tetraédrica foram enriquecidas em isótopos pesados (+0.33\%o), enquanto que os compostos de $\mathrm{Zn}$ com geometria octaédrica foram enriquecidas em isótopos leves (-0.04 \%) (Aucour et al., 2013). Tais resultados têm implicações importantes para o rastreamento de fontes uma vez que as assinaturas isotópicas de fontes podem ser modificadas por processos que modifiquem a coordenação ou, melhor dizendo, a especiação do Zn. Em solos contaminados, alterações das assinaturas isotópicas originais das fontes antrópicas de Zn foram reportados, e atribuídos às diversas reações químicas e a influência da vegetação no solo (Juillot et al., 2011).

No oceano, os dados do oceano Austral, Atlântico Norte e Pacífico Norte, são notavelmente homogêneos, com uma média de $\delta^{66 / 64} \mathrm{Zn}=+0.53 \pm 0.14 \%$ o $(2 \sigma= \pm 0,03, n=21)$. A superfície Oceano Antártico é mais variável, com $\delta^{66 / 64} \mathrm{Zn}$ variando de +0.07 a $+0.80 \%$. Uma delimitada faixa de profundidade entre 40-80 m nestes oceanos mostrou valores mais leves, próximos de $+0.3 \%$, possivelmente associados com processos de incorporação biológica preferencial do isótopo leve. Assim, a atividade primária e a remoção do isótopo leve tem sido evocados para explicar as composições isotópicas mais pesadas de sedimentos marinhos autigênicos, incluindo nódulos Fe$\operatorname{Mn}\left(\delta^{66 / 64} \mathrm{Zn}=0.90 \pm 0.28 \%\right.$; . Maréchal et al, 2000), carbonatos biogênicos; e opala biogênica 
$\left(\delta^{66 / 64} \mathrm{Zn}=0.91 \pm 0.24 \%\right.$ Pichat et al., 2003) $\left(\delta^{66 / 64} \mathrm{Zn}=0.76-1.47 \%\right.$; Andersen et al, 2011). No entanto, balanços de massa entre entradas e saídas de isótopos de $\mathrm{Zn}$ nos oceanos não fecham, indicando que um sumidouro de isótopos leves ainda precisa ser identificado (Little et al., 2014).

Fracionamento isotópico por processos biológicos também foram evocadas para explicar as variações temporais de valores $\delta^{66 / 64} \mathrm{Zn}$ em partículas de um lago suíço temperado (Lago Greifen, Peel et al., 2009). Estas amostras apresentaram variações de valores de $\delta^{66 / 64} \mathrm{Zn}$ entre $0.66 \mathrm{a}+0.21 \%$, com os valores mais negativos observados após o período de alta produtividade primária na primavera e verão. O padrão temporal observado foi consistente com a captação preferencial do $\mathrm{Zn}$ isótopo leve na biomassa algal durante os períodos de alta produtividade primária. O fracionamento isotópico biológico de $\mathrm{Zn}$ também tem sido utilizado para avaliar produtividade primária ao longo do tempo geológico, a partir do registro estratigráfico de carbonatos (Pichat et al.2003). Dados isotópicos de Zn de dolomitos neoproterozóicos da formação Nuccaleena, sul da Austrália, foram interpretadas como o crescimento da evolução da atividade primária que sucedeu períodos posteriores a deglaciação do planeta.

Em minérios sulfetados de $\mathrm{Zn}$, composições isotópicas apresentam média de valores $\delta^{66 / 64} \mathrm{Zn}$ em torno $+0.16 \pm 0.20 \%(2 \sigma, n=10$ minas, $n=61$ análises $)$. Carvões minerais apresentam valores de $\delta^{66 / 64} \mathrm{Zn}_{\text {JMC }}$ entre +0.13 a +0.88 (Borrok et al, 2010;. Gonzalez e Weiss; 2016). As assinaturas isotópicas de minérios e carvões têm implicações importantes para produtos finais e subprodutos produzidos em usinas metalúrgicas e térmicas. Processos de alta temperatura empregadas no refino de minérios de sulfeto e combustão de carvão induzem importantes fracionamento de isótopos, com o enriquecimento dos $\mathrm{Zn}$ isótopos leves na fase de vapor e dos isótopos pesados no material residual (Sivry et al, 2008; Borrok et al, 2010; Yin et al, 2015; Gonzalez e Weiss, 2016). No caso do refino de minérios, a etapa de eletrólise também pode fracionar isotopicamente o $\mathrm{Zn}$, como demonstrado em experimentos eletroquímicos controlados (Kavner et ai, 2008, Black et ai, 2011; Black et ai, 2014), no entanto, seu fracionamento industrial ainda não foi mensurado. Aparte dessas lacunas relativas aos efeitos eletroquímicos, uma tendência geral é observada no processo de refino do Zn: emissões atmosféricas produzidas no processo apresentam a assinatura mais leve com valores baixos de $\delta^{66 / 64} \mathrm{Zn}$, atingindo valores negativos próximos a -0.66 \% (Mattielli et al, 2009); rejeitos sólidos ou escórias apresentam valores de $\delta^{66 / 64} \mathrm{Zn}$ mais pesados, com valores de até $+1.49 \%$ (Sivry et al., 2008); e os produtos refinados 
(Zn metálico) com composições isotópicas próxima dos minérios usados como matéria prima $\left(\delta^{66 / 64} \mathrm{Zn}=+0.22 \%\right.$, Yin et al., 2015). A diferença significativa nas composições isotópicas derivadas de fontes antropogênicas em comparação com as amostras naturais (solos e rochas, por exemplo) habilita os isótopos de Zn como um poderoso traçador das fontes capazes de discriminar e quantificar várias fontes poluentes, como subprodutos da mineração e metalurgia (Dogolopova et al, 2006;. Mattielli et al, 2006;. Weiss et al, 2007;. Sivry et al, 2008), e emissões do tráfico veicular nas grandes cidades (Gioia et al, 2008;.. Thapalia et al, 2015) e águas residuárias e esgotos (Chen et al, 2008;. 2009).

O crescente números de grupos de pesquisa em biogeoquímica isotópica de metais contribuirá para o contínuo desenvolvimento de novas metodologias e avanços na compreensão teórica sobre os fatores que controlam o seu fracionamento isotópico na natureza. Desafiador, mas promissor é o acoplamento entre técnicas cromatográficas de separação (GC ou HPLC) e os instrumentos MC-ICP-MS para análises isotópicas combinadas com a especiação. Esta combinação de informações é fundamental para a compreensão dos ciclos biogeoquímicos e ambientais, e pode abrir novas fronteiras de aplicações na biomedicina a partir da investigação da razões isotópicas de metaloproteínas (Albarède, 2015).

Futuros estudos são necessários para ligar a especiação Zn e biodisponibilidade e mecanismos de fracionamento isotópico durante a sua incorporação à biota, e sua subsequente partição no interior do corpo humano e animal. O desenvolvimento de extração seletiva ou sequencial para análise isotópica das diferentes fases de solos e sedimentos poderia ser uma ferramenta auxiliar interessante para compreender o fracionamento isotópico durante a captação. No entanto, protocolos mais robustos e reprodutíveis são necessários, além da verificação de possíveis artefatos associados ao procedimento químico. Além dos avanços analíticos e metodológicos, investigações adicionais como depósitos minerais, incluindo aqueles com fases minerais não-sulfetadas, como ocorre em alguns depósitos brasileiros (Vazante, Minas Gerais), podem fornecer novos insights sobre a gênese dos sistemas de minério. Concomitantemente, novos esforços para aumentar o conjunto de dados em compartimentos ambientais podem contribuir para identificar as fontes e sumidouros do $\mathrm{Zn}$ antrópico e seus fluxos através do biogeosfera, seja em escala local ou global. 
Por fim, novos experimentos laboratoriais controlados e desenvolvimentos teóricos sobre os efeitos de coordenação química do Zn com diferente diferentes ligantes serão úteis para interpretar e predizer o fracionamento isotópico no ambiente e sistemas biológicos, abrangendo desde perfis estratigráficos de $\mathrm{Zn}$ ao longo do tempo geológico até os processos metabólicos que ocorrem nas células.

\section{Capítulo 4- Cromatografia de troca iônica e correções de viés de massa para medição acurada e precisa das razões isotópicas de $\mathrm{Zn}$ em amostras ambientais de referência por MC-ICP-MS}

Neste trabalho, apresentamos dados $\delta^{66 / 64} \mathrm{Zn}$ precisos e acurados para materiais de referência (MRs), incluindo rochas, sedimentos, solos e plantas, a fim de melhorar a rastreabilidade metrológica e controle analítico das determinações de isótopos de $\mathrm{Zn}$ em futuros estudos ambientais. Nós ajustamos um protocolo de cromatografia de troca iônica simplificado para permitir uma rápida obtenção de Zn de amostras naturais e investigamos os processos de viés de massa. O protocolo cromatográfico ajustado produziu elevadas recuperações de Zn $(99 \pm 7 \%, \sigma, n$ =16), enquanto a correção do viés de massa, utilizando a normalização externa com um padrão de $\mathrm{Cu}$ produziu precisões, em média, de $0.02 \%, 2 \sigma, n=7$. As investigações sobre interferências espectrais e não-espectrais identificaram a formação significativa de óxidos e hidróxidos de espécies iônicas de Cr e Ti. A análise de seis MRs (basalto BHVO-2; basalto BCR-2; andesito AGV-2; solo 2709 San Joaquin, sedimento estuarino 1646a e folha de tomate 1573a) mostraram boa reprodutibilidade $(<0.10 \%, 2 \sigma, 5 \leq \mathrm{n} \geq 1)$.

\section{Capítulo 5- Isótopos de Zn como traçador de rejeitos metalúrgicos em ambientes costeiros}

Neste capítulo, a legitimidade de $\mathrm{Zn}$ isótopos para rastrear fontes antropogênicas nas zonas costeiras foi averiguada. As composições isotópicas de $\mathrm{Zn}$ foram determinadas em testemunhos de sedimentos, sedimentos superficiais, material particulado em suspensão (MPS), folhas de árvores 
de mangue e as rochas da Baía de Sepetiba, um estuário lagunar impactado por uma área costeira industrializada perto do Rio de Janeiro, Brasil. Amostras de minérios, oriundas de depósitos minerais brasileiros também tiveram suas composições isotópicas de $\mathrm{Zn}$ determinadas. O objetivo foi testar isótopos de $\mathrm{Zn}$ como um traçador capaz de i) identificar fontes e sumidouros do $\mathrm{Zn}$ antropogênico; ii) reconstruir a evolução temporal e espacial da contaminação de $\mathrm{Zn}$; iii) verificar a influência dos processos biogeoquímicos estuarinos na assinatura isotópica Zn durante seu transporte e deposição e iv) avaliar os efeitos da contaminação antrópica sobre as assinaturas isotópicas de $\mathrm{Zn}$ em folhas de mangue. As composições isotópicas de $\mathrm{Zn}$ (expressa utilizando a notação $\delta^{66 / 64} \mathrm{Zn}$ relativa à solução JMC 3-0749-L) mostraram variações significativas nos testemunhos de sedimento, MPS, folhas e minérios de willemita, variando entre $-0.01 \mathrm{a}+1.15 \%$. Análise espacial e temporal das amostras de sedimentos se adequaram à um modelo de mistura envolvendo três principais fontes: i) materiais detríticos continentais transportados via rios $\left(\delta^{66 / 64} \mathrm{Zn}_{\mathrm{JMC}}=+0.28 \pm 0,12 \%\right.$ o, $\left.2 \sigma\right)$; ii $)$ materiais marinhos $\left(\delta^{66 / 64} \mathrm{Zn}_{\mathrm{JMC}}=+0,45 \pm 0,03 \%\right.$ o, $\left.2 \sigma\right)$ e iii $)$ materiais antrópicos associada aos rejeitos da galvânica $\left(\delta^{66 / 646} \mathrm{ZnJ}_{\mathrm{MC}}=+0.86 \pm 0,15 \%\right.$ \% $\left.2 \sigma\right)$. Um modelo de mistura com duas fontes, abrangendo os rejeitos da galvanoplastia e os materiais terrígenos, indicaram contribuições dos rejeitos metalúrgicos no teor total de $\mathrm{Zn}$ nos sedimentos próximos de $80 \%$ durante períodos de funcionamento da atividade galvânica. Testemunhos de sedimentos coletados na planície de lama mostraram altas correlações entre os valores de $\delta^{66 / 64} \mathrm{Zn}$ e fatores de enriquecimento de $\mathrm{Zn}$, indicando boa preservação dos registros isotópicos das fontes naturais e antropogênicas e sem fracionamento isotópico significativo durante o transporte estuarino de sedimentos ou por reações diagenéticas no sedimento de fundo. Um testemunho de sedimentos amostrado no mangue localizado à zona mais impactada pela metalurgia apresentou níveis de Zn superiores a 4\% (sedimento de peso seco) e preservou as assinaturas isotópicas dos rejeitos da galvanoplastia. No entanto, há evidências de que os processos biogeoquímicos desencadeados pela hidrodinâmica, bioturbação e processos na rizosfera alteraram ligeiramente as assinaturas isotópicas em algumas camadas para valores mais positivos $\delta^{66 / 64} \mathrm{Zn}_{\text {JMC }}$ acima de +1.0 \%o. As assinaturas isotópicas de $\mathrm{Zn}$ não permitiram a identificação das fontes devido ao fracionamento isotópico relacionado à sua incorporação ao tecido vegetal. Folhas coletadas nos sítios com elevados níveis de contaminação exibiram um diferente padrão isotópico em relação às demais áreas pouco ou não contaminados. Esses diferentes padrões podem estar associados à 
mecanismos de tolerância de árvores de mangue, onde o Zn atinge níveis tóxicos. Em conclusão, o nosso trabalho sugere que composições isotópicas de $\mathrm{Zn}$ de sedimentos são traçadores confiáveis de fontes antropogênicas e, portanto, uma ferramenta valiosa para auxiliar a prevenção e monitorização em zonas costeiras. Por sua vez, as composições isotópicas de Zn de folhas são promissoras como biomarcadores de efeitos fisiológicos associados à contaminação por metais.

\section{Capítulo 6- Composições isotópicas de Zn de moluscos bivalves de um estuário brasileiro: implicações para biomonitoramento de contaminação por metais}

Determinação do zinco ( $\mathrm{Zn}$ ) isótopos nos tecidos bivalves têm sido explorados como uma inovadora ferramenta de biomonitoramento de contaminação por metais, potencialmente capaz de integrar informações acerca das fontes, destinos e biodisponibilidade do Zn. No entanto, a sua aplicabilidade permanece inconclusiva na literatura até o presente momento. A fim de investigar a aplicabilidade do das assinaturas bioisotópicas de $\mathrm{Zn}$ dos tecidos de bivalves para rastreamento de fontes ou inferências acerca de processos biogeoquímicos, realizamos um estudo com moluscos bivalves (Crassostrea brasiliana e Perna perna) e amostras de material particulado em suspensão (MPS) coletados a partir de um estuário tropical historicamente impactado por atividades metalúrgicas (Baía de Sepetiba, sudeste do Brasil). A sistemática de isótopos de Zn das amostras de MPS permitiram a identificação de fontes e processo de mistura no sistema fluvial-estuarino. Por sua vez, a sistemática $\mathrm{Zn}$ isótopos de tecidos bivalves distinguiu dois grupos: o primeiro formado por amostras de bivalves coletados na zona metalúrgica de idade $\left(\delta^{66 / 64} \mathrm{Zn}_{\mathrm{JMC}}+0.49 \pm\right.$ $0.06 \%$ o, $2 \sigma, n=3)$ e um segundo grupo composto pelas demais estações de amostragem (+0.83 \pm $0.10 \%, 2 \sigma, n=22)$. As assinaturas isotópicas dos bivalves não permitiram a identificação de fontes ou tendências do processo de mistura, sugerindo limitações às fontes de rastreamento. Encontramos, no entanto, que a sistemática de isótopos de Zn de bivalves da baía de Sepetiba pode estar relacionada com o mecanismo de bioacumulação, ou seja, a captação via dissolvido e fase particulada. Supõe-se que, na zona fortemente impactada pelos antigos rejeitos da atividade de 
galvanoplastia, os bivalves incorporam altos níveis de $\mathrm{Zn}$ da fase dissolvida através de suas brânquias e com acumulação a nível celular promovida pela difusão facilitada ou transporte ativo de membrana. Fora desta zona, devido ao baixo teor de $\mathrm{Zn}$ na fase dissolvida e altas concentrações deste elemento no material particulado em suspensão, bivalves incorporam a fração de $\mathrm{Zn}$ biodisponível associado às partículas durante a digestão intestinal. A confirmação da nossa hipótese de usar isótopos de Zn como traçador de rotas de bioacumulação seria de grande interesse para a gestão ambiental relativa à definição de critérios de qualidade de água e sedimento. Futuros estudos laboratoriais sob ambiente controlado podem fornecer novos entendimentos acerca da relação de biodisponibilidade, especiação de Zn e seu fracionamento isotópico em bivalves.

\section{Capítulo 7- Conclusões}

As composições isotópicas de $\mathrm{Zn}$ de sedimentos foram capazes de detectar e quantificar espacialmente e temporalmente mudanças biogeoquímicas desencadeadas por atividades antropogênicas. Portanto, a análise isotópica de $\mathrm{Zn}$ em sedimentos se apresenta como uma valiosa ferramenta em estudos de prevenção, monitoramento e previsão de riscos em zonas costeiras afetadas pela contaminação por metais.

As composições isotópicas de Zn em amostras de folhas de árvores de mangue não são adequadas para rastrear fontes, porém, os distintos padrões isotópicos entre as amostras coletadas em áreas contaminadas e não contaminadas são promissores quanto ao uso dos isótopos de $\mathrm{Zn}$ como biomarcadores de efeitos fisiológicos e mecanismos de tolerância ativados pela contaminação de $\mathrm{Zn}$.

A determinação isotópica de $\mathrm{Zn}$ em moluscos bivalves mostrou-se potencialmente capaz de traçar fontes, no entanto, mais estudos são necessários para compreender como a especiação do Zn e sua biodisponibilidade afetam o seu fracionamento isotópico durante a incorporação por estes organismos. Adicionalmente, os resultados apresentados neste trabalho apontam o grande potencial para elucidar rotas de bioacumulação de invertebrados aquáticos. Esse conhecimento pode ser útil 
para aplicar isótopos de Zn como ferramenta auxiliar na definição de critérios de qualidade de água e sedimento e fornecer novos insights sobre a transferência de metal para cadeias alimentares dos ecossistemas costeiros.

Futuros estudos devem ser direcionados à interface sedimento-água para melhor compreensão dos processos digenéticos sobre as composições isotópicas de Zn e a especiação deste elemento. Este estudo é fundamental para melhor interpretar os dados isotópicos de amostras biológicas. 